



\section{TENDENCIAS JURÍDICAS DEL DERECHO PÚBLICO}





\author{
Diego Fernando Peña Peña \\ Juan Camilo Martínez Turmequé \\ Ciro Nolberto Güechá Medina \\ Javier Eduardo Rocha Amarís \\ Diego Hernán Morales Sánchez \\ Álvaro Moreno Duran \\ ANDrÉS Abel Rodríguez Villabona
}

\title{
TENDENCIAS JURÍDICAS DEL DERECHO PÚBLICO
}


C Diego Fernando Peña Peña Juan Camilo Martínez Turmequé Ciro Nolberto Güechá Medina Javier Eduardo Rocha Amarís Diego Hernán Morales Sánchez Álvaro Moreno Duran Andrés Abel Rodríguez VillabonaA

(C) Universidad Santo Tomas Carrera 9 No. 72-90 Facultad de Derecho Bogotá - Colombia
(C) Grupo Editorial IbáÑEZ Carrera 69 Bis № 36-20 Sur Teléfonos: 2300731 - 2386035 Librería: Calle 12B № 7-12 L.1 Tels.: 2835194 - 2847524 Bogotá, D.C. - Colombia www.grupoeditorialibanez.com

ISBN: 978-958-749-623-9

Diseño de carátula: Kevin Nuñez

Diagramación electrónica: Deissy Alejandra Rodríguez

Queda prohibida la reproducción parcial o total de este libro por cualquier proceso reprográfico o fónico, especialmente por fotocopia, microfilme, offset o mimeógrafo.

Ley 23 de 1982

(R) 2016 


\section{COMITÉ EDITORIAL}

Germán Lozano Villegas

Doctor en Derecho - Universidad

Externado de Colombia

Docente de la Universidad

Externado de Colombia

\section{Misael Tirado Acero}

Pos Doctor en Sociología

Jurídica - Universidad de

Buenas Aires de Argentina

Docente de la Universidad

Católica de Colombia

Omar Huertas Díaz

Magister en Derecho Penal

Docente de la Universidad

Nacional

Rubén Vélez Núñez

Doctor en Integración -

Universidad Andina Simón Bolívar

Docente Universidad

Simón Bolívar

\section{COMITÉ CIENTÍFICO}

Laura Wendy Zazueta Carrillo Doctora en Derecho - Universidad

Juárez del Estado de Durango

Docente Investigadora de la Facultad de Derecho

y Ciencias Políticas

Universidad de Juárez del

Estado de Durango
Marco Bustos Gutiérrez

Doctor en Ciencias Sociales Facultad Latinoamericana de

Ciencias Sociales, sede México

Docente de la Universidad

Católica de Temuco - Chile

Sandra Rocío Gamboa Rubiano

Doctora en Derecho

Universidad Santo Tomás

Docente Universidad

Gran Colombia

Martín Risso Ferrand Doctor en Ciencias Sociales Universidad de Buenos Aires

Director del Departamento de Derecho Constitucional y Derechos Humanos en Universidad Católica del Uruguay.

\section{PARES ACADÉMICOS}

Gustavo A. Quintero Navas

Doctor en Derecho Publico

- Université De Nantes

Docente Universidad de los Andes

Diego M. Higuera Jiménez

Doctor en Derecho - Universidad

Externado de Colombia

Investigador Instituto

de Victimologia Fray

Bartolomé de las Casas. 



\section{CONTENIDO}

INCIDENCIA DE LOS SILENCIOS LEGISLATIVOS

EN SITUACIONES JURÍDICAS PREVISTAS EN LA CONSTITUCIÓN

Diego Fernando Peña Peña - Juan Camilo Martínez Turmequé. 13

LA JURISDICCIÓN DE LO CONTENCIOSO

ADMINISTRATIVO EN COLOMBIA: UNA EXPRESIÓN

DE EXISTENCIA DEL CONSEJO DE ESTADO

Ciro Nolberto GüEChá Medina

PERSPECTIVA DE LAS TECNOLOGÍAS

DE LA INFORMACIÓN Y DE LAS COMUNICACIONES

EN EL BLOQUE DE CONSTITUCIONALIDAD EN COLOMBIA

Javier Eduardo Rocha Amarís - Diego Fernando Peña Peña

PRECEDENTE ADMINISTRATIVO EN COLOMBIA:

APROXIMACIÓN A UN MODELO DE UNIFICACIÓN JURISPRUDENCIAL

Diego Hernán Morales Sánchez - Álvaro Moreno Duran

LA CONSTITUCIÓN Y EL CONSTITUCIONALISMO:

SU DIVERSIDAD CONCEPTUAL, HISTÓRICA Y SOCIAL

ANDRÉS AbEl RodríGueZ Villabona 



\title{
PRESENTACIÓN
}

\author{
Carolina Blanco Alvarado \\ Doctora en Derecho - Universidad Santo Tomas \\ Compiladora Académica
}

Desde siempre, las cuestiones sociales y políticas que preocupan a la sociedad han obligado a los juristas a revisar la rigidez con la que muchos conceptos e instituciones jurídicas fueron introducidos y desarrollados en nuestras sociedades. Esta situación se ha presentado, porque los eventos que presionan cambios y que necesitamos para avanzar como grupos humanos organizados llevan a replantearse sin cesar cómo se debe pensar el derecho, circunstancia que obliga a los juristas a reflexionar permanentemente sobre la articulación del Derecho en la sociedad.

Desde la citada perspectiva, el presente libro es testimonio del replanteamiento continuo de cómo se debe pensar el derecho, y de cómo la imaginación y la innovación son la línea directriz para que la ciencia jurídica sea un mecanismo al servicio de la sociedad y no un muro que le impida avanzar.

Los capítulos del presente libro ofrecen temáticas relacionadas principalmente con las áreas del Derecho Constitucional y el Derecho Procesal Administrativo. Para el efecto se desarrollan aspectos como los silencios legislativos en el marco de la carta política colombiana; la naturaleza jurídica o razón de ser del Consejo de Estado desde una perspectiva cualitativa e historia y evidenciando un comparativo con el Consejo de Estado Francés; bloque de constitucionalidad desde las tecnologías de la información y de las comunicaciones. Atendiendo el contenido dispuesto por la ley 1437 de 2011, el libro evidencia un capítulo relacionado con la figura de unificación jurisprudencial, aportando una metodología para su logro y un comparativo entre España, Costa Rica y Colombia, finalizando con una propuesta de unificación jurisprudencia en el marco de la privación injusta de la libertad. Nuestro libro culmina con una reflexión sobre las diferencias entre constitución y constitucionalismo, apoyándose en las perspectivas social e histórica. 
En el marco de las actuales políticas de Colciencias, las cuales suponen entre otros aspectos, el funcionamiento de líneas, grupos de investigación y la articulación de los mismos; y como consecuencia de este último aspecto, la cohesión, cooperación y colaboración en la producción académica de investigadores; es importante anotar que con el ánimo de cumplir las referenciadas políticas, en especial con los índices de cooperación, colaboración y cohesión; la facultad de Derecho de la Universidad Santo Tomas presenta a la Comunidad Académica las páginas que a continuación se desarrollaran y que responden a la producción académica resultado de los proyectos de investigación institucionales de la mencionada facultad.

En este orden de ideas, el presente libro cumple con los presupuestos exigidos por Colciencias como Libro de Investigación, ya que el contenido del mismo ha sido producto de proyectos de investigación ejecutados por los respectivos autores en el marco del Centro de Investigaciones de la Facultad de Derecho de la Universidad Santo Tomas; y porque todos los capítulos de libro recibidos para conformar el presente libro contaron con la evaluación de pares académicos nombrados por el Comité Editorial del libro, y con base en estos y en las recomendaciones hechas por el editor y compilador académico, se tomó la decisión de publicar aquellos que tuvieron las mejores evaluaciones y que cumplieron con las condiciones académicas exigidas.

De otro lado, es importante anotar que el libro evidencia el cumplimiento del índice de colaboración y cohesión, factor de importancia para Colciencias en la categorización de Grupos de Investigación, aspecto que se evidencia con el capítulo de libro de los profesores Diego Morales y Álvaro Moreno, quienes conjuntamente quisieron participar en la presente producción académica a través del capítulo de libro: Precedente Administrativo en Colombia: Aproximación A un Modelo de Unificación Jurisprudencial. 


\title{
INCIDENCIA DE LOS SILENCIOS LEGISLATIVOS EN SITUACIONES JURÍDICAS PREVISTAS EN LA CONSTITUCIÓN*
}

\author{
Diego Fernando Peña Peña ** \\ Juan CAmilo Martínez TurmequÉ ${ }^{* * *}$
}

\section{INTRODUCCIÓN}

Se ha dicho que no todos los silencios del legislador son constitutivos de una omisión contraria a la Constitución. Es cierto que hay silencios legislativos inocuos, que carecen de las consecuencias normativas que los hacen jurídicamente relevantes. Incluso éstos, los silencios relevantes jurídicamente, sólo serán omisiones inconstitucionales, si las mencionadas consecuencias normativas se manifiestan contrarias a la Constitución. Es falso sostener que los silencios legislativos son todos ellos irrelevantes e inofensivos desde la perspectiva jurídica, y que, por consiguiente, todo intento de someterlos a control es un modo sutil de controlar políticamente al legislador democrático. Que esta idea es falsa y que, en efecto, no todo silencio es una omisión inconstitucional, son consecuencias de las distintas formas que la Constitución emplea para articular su relación con el legislador ${ }^{1}$.

* El presente capítulo de libro es producto del proyecto de investigación: “CONTROL CONSTITUCIONAL DE LOS SILENCIOS LEGISLATIVOS. Perspectiva, Propuesta y Desarrollo en el Derecho Comparado", por el cual el Autor Juan Camilo Martínez obtuvo el titulo de magister en Derecho Publico.

** Candidato a Magister en Derecho Público - Universidad Santo Tomás. Docente e Investigador del Centro de Investigaciones de la Facultad de Derecho de la USTA. Correo Electrónico: diego.magister@hotmail.com

*** Magister en Derecho Público (UNIVERSIDAd SANTO TOMAS - UNIVERSIDAD DE KONSTANZ). Docente e Investigador de la Universidad Santo Tomas. Sede Bogotá. Correo Electrónico: camilomartinezt@gmail.com

1 Así parece ser el enfoque empleado por varios autores alemanes como Götz Meder, „Verfassungsbeschwerde gegen gesetzgeberischesUnterlassen“, Deutsches Verwaltungsblatt, 1971, pp. 848 y ss., p. 850; también de Ernst-Hasson Ritter, „Verfassungsrechtliche Gesetzgebungspflichten“, Bonn, 1967 (texto impreso por el 
En ciertos casos, la Constitución atribuye al legislador la competencia para ser él quien tome una concreta decisión a la que el constituyente ha renunciado o, simplemente, le erige en el único competente para regular una genérica materia $^{2}$. En estos casos, el silencio legislativo (si la ley no establece esas penas o no hay ley que regule el ejercicio de cierto derecho fundamental) no tiene por qué ser contrario a la Constitución ${ }^{3}$. En un caso, el primero, la intermediación legislativa es la condición necesaria para que lo previsto por la Constitución exista en el ordenamiento; pero también su inexistencia como consecuencia del silencio legislativo está constitucionalmente prevista y permitida. En el otro, el segundo, la Constitución le atribuye sin más una competencia; ejercerla o no es, en principio, una decisión discrecional del legislador, que no afecta a la existencia jurídica de lo querido por la norma constitucional (el derecho fundamental existe sin necesidad de que el legislador regule su ejercicio).

Sin embargo, hay supuestos en los que la Constitución no sólo atribuye al legislador una competencia para hacer algo, sino que, además, lo hace en un tono imperativo (por ejemplo, el art. 179 CPC, la ley establecerá las causas de ineligibilidad e incompatibilidad de los congresistas), o casos en los que es razonable pensar que el constituyente ha querido que exista una determinada realidad jurídica en el ordenamiento y le encomienda la concreción de su modo de existencia al legislador (por ejemplo, el art. 216

servicio de publicaciones de la Universidad de Bonn de su Dissertation doctoral); y de Konrad Stahler, „Verfassungsrechtliche Nachprüfung gesetzgeberischen Unterlassens“, München, 1966. Semejante conexión fue insinuada en la decisión del Tribunal Constitucional Federal de la República Federal de Alemania 1, 97 (105), según la cual, la inobservancia arbitraria por el legislador de sus deberes de ejecución de los mandatos del Estado Social podría ser impugnable mediante un recurso de amparo constitucional (Verfassungsbschwerde) por el individuo que viera de esta forma lesionado alguno de sus derechos constitucionales. No parece haber sido una línea jurisprudencial fértil en Alemania, ni tampoco parece posible que la Corte Constitucional llegue a sostener una idea similar. Por el contrario, hay autores que sostienen, precisamente, que el silencio legislativo sobre los mandatos del Estado social no son controlables jurídicamente dada la estructura de sus normas de programación final: como lo indica Joaquim Gomes Canotilho en su Dereito Constitucional, Almedina, Coimbra. 1995 (6 Edición), p. 1089.

2 Véase al respecto el artículo de Rainer Wahl. „Der Vorrang der Verfassung“. Der staat, Bd.20. Hf. 4, 1981, pp. 485 y ss. p. $487 .$.

3 Por mucho que pueda argüirse que puede que ese silencio tampoco sea del todo constitucionalmente adecuado. Si en el examen de la constitucionalidad de una norma se exige la contradicción con la norma o normas constitucionales supuestamente vulneradas para poder declarar su inconstitucionalidad, y no basta con la mera indiferencia de la ley respecto de la Constitución, no cabe exigirle más al examen del silencio del legislador para enjuiciar. 
inciso 3 CPC, la ley regulará la objeción de conciencia al servicio militar). Tales son los términos en los que se expresa la norma constitucional en estos supuestos, que el silencio legislativo sobre el particular puede crear situaciones jurídicas contrarias a la Constitución.

La diferencia en unos casos u otros no debe buscarse en la simple literalidad del precepto ni en la naturaleza de la competencia atribuida por la Constitución al legislador. En todos ellos la Constitución quiere que la existencia de una determinada situación jurídica o su concreción en el ordenamiento jurídico competan al legislador y a sus normas con rango de ley (reserva de ley). La diferencia reside en la disponibilidad sobre la existencia de la situación jurídica constitucionalmente prevista. Cuando la situación jurídica en cuestión existe si y sólo si el legislador lo quiere, pues la Constitución ha hecho dejación en él de la competencia para tomar esa decisión, el silencio legislativo es constitucionalmente irrelevante o está permitido. Otra cosa sucede si la Constitución ordena o prohíbe la existencia de esa situación jurídica, incluso si simplemente la permite expresamente. La existencia o la inexistencia de la situación ya no está a disposición del legislador, que no podrá disponer de ella ni con la ley, ni con su inactividad ${ }^{4}$.

\section{SILENCIO LEGISLATIVO Y CONSTITUCIÓN}

La clave en el análisis de la compatibilidad entre los silencios del legislador y la Constitución radica en los efectos que su quiescencia puede ocasionar en el diseño que la Constitución haya hecho del ordenamiento jurídico. Esos efectos son las situaciones jurídicas creadas o conservadas por el silencio legislativo. Esas situaciones jurídicas son el régimen jurídico de una materia dada, es decir, el conjunto de normas explícitas o implícitas que regulan esa materia. Cuando ese régimen jurídico emana de normas implícitas cuya aplicación es provocada por el silencio legislativo, y cuando la situación jurídica así creada es contraria a la permitida u ordenada por la Constitución, se está ante omisiones inconstitucionales del legislador o de sus leyes. Esos silencios pueden vulnerar la Constitución por motivos formales, si el silencio contraría una norma constitucional que reserva en exclusiva esa regulación a un determinado tratamiento jurídico, o competenciales, si el silencio da

$4 \quad$ Véase el libro de Markus van den Hövel, Zuläsgkets- und Zulassungsprobleme der Verfassungsbeschwerde gegen Gesetze, Duncker \& Humblot, Berlin, 1990, pp. 63 y ss. 
cobertura a actos de creación o aplicación normativas que invaden el ámbito competencial de otro sujeto del ordenamiento jurídico; y, por supuesto, lo pueden hacer por motivos materiales, impidiendo o prohibiendo, según el caso, la existencia de la situación jurídica querida por la Constitución en la misma norma constitucional que permite $u$ ordena la actividad del legislador o bien lo hace de una situación jurídica querida en una norma constitucional distinta. Con el término "situaciones jurídicas" no se trata, pues, de identificar las circunstancias de hecho que el silencio legislativo alienta o ha creado. El problema que aquí interesa no es un problema de eficacia del silencio del legislador y de sus leyes, sino de validez de la situación jurídica creada por ese silencio, por tanto, de validez de la norma implícita que constituye su régimen jurídico ${ }^{5}$.

A continuación nos vamos a ocupar de las diversas situaciones jurídicas previstas por la Constitución, y de qué modo incide en ellas el silencio legislativo. Téngase en cuenta que se trata de una sistematización, siempre acompañada de un cierto grado de generalización e inevitable simplificación de la inmensa variedad de posibilidades, para la que se han utilizado los

Téngase en cuenta que aquí se usaran los términos "Estado liberal" y "Estado democrático" aludiendo dos formas de concebir el ordenamiento jurídico del "Estado constitucional", caracterizándose la primera por la atribución de la soberanía a la Nación o al Parlamento, lo que lleva aparejado por regla general la afirmación de la supremacía normativa de la ley (esto es, el Estado propio del Constitucionalismo). Mientras que el Estado democrático supone la atribución de la soberanía al pueblo y la supremacía normativa de la Constitución como forma diversa a la ley. Obsérvese también como el tránsito del Estado liberal al democrático afecta en este caso a la existencia y posición en el ordenamiento de la forma jurídica "Constitución", pero no necesariamente al concepto de "norma constitucional" o al tipo de funciones que le toca desempeñar. El problema, obviamente, es de atribución de la soberanía. En el Estado liberal aún se afirma la existencia de un sujeto titular de la soberanía. Mientras que en el Estado democrático cobra sentido la idea de Constitución sin soberano, objetivando la soberanía en la Constitución como forma jurídica diversa a la ley, con el objeto de sortear el riesgo, que acompaña a la "democracia de identidad", de la negación del Estado y de la fundamental distinción entre titularidad y ejercicio de la soberanía. 
siguientes criterios: el tipo de norma constitucional afectada (autoaplicativa, permisiva o imperativa), el grado de disponibilidad sobre la existencia de la situación jurídica prevista por la norma constitucional que posee el legislador (absolutamente indisponible, abierta al desarrollo legislativo y disponible) y la incidencia que pueda tener el silencio legislativo (silencio del legislador u omisión absoluta y silencio de la ley u omisión relativa) sobre dicha situación, impidiendo o prohibiendo su existencia.

\section{NORMAS CONSTITUCIONALES AUTOAPLICATIVAS Y PERMISOS CONSTITUCIONALES}

Se trata de los casos extremos en los que o la situación jurídica es absolutamente indisponible al legislador (normas constitucionales autoaplicativas) o su existencia está a su libre disposición (normas constitucionales permisivas) ${ }^{6}$.

La Constitución puede contemplar situaciones jurídicas cuya existencia es indisponible a los Poderes del Estado, en particular al legislador. Y esas situaciones pueden emanar de normas constitucionales autoaplicativas (por ejemplo, el art. 322 CNC: Bogotá, Capital de la República...). En este caso la situación jurídica existe ya con la mera presencia de la norma constitucional. Es el supuesto más evidente de eficacia directa de la Constitución. El silencio del legislador no tiene relevancia alguna, pues no podrá producir normas que desplacen a la constitucional (si el legislador calla eso no quiere decir que la capital de Colombia pudiera ser otra distinta a la ciudad de Bogotá). Si la Constitución puede regular directamente una materia determinada, no puede hablarse en puridad de silencio legislativo y menos aún de omisiones inconstitucionales (aunque el legislador pudiera complementar la norma constitucional). En esta circunstancia, de normas constitucionales autoaplicativas, no son posibles, pues, ni omisiones absolutas ni omisiones relativas inconstitucionales, pues el vacío que pudiera crear el silencio legislativo siempre estará ocupado por la norma constitucional y no podrá crearse ni conservarse situación jurídica alguna contraria a la Constitución, dado que su norma despliega toda su eficacia directa en lo que hace a su contenido normativo. Quien, no obstante, pretenda eludir la directa aplicación de estas normas constitucionales, amparándose en el silencio

Al respecto, Ver Jellinek, G. „Sistem der subjektiven öffentlichen Rechte“, Sienta Verlang Aalen. Tübingen, 1979, p. 98. 
legislativo, no sólo reduce la norma constitucional autoaplicativa a mera norma programática necesitada de mediación legislativa para ser eficaz, sino que, además, la infringe (y no el silencio) al inaplicarla ${ }^{7}$.

La Constitución también puede establecer que la existencia y concreción en el ordenamiento jurídico de ciertas situaciones jurídicas quede al destino de cualquiera de los Poderes del Estado con poder jurídico para crear normas que regulen esa materia o exclusivamente del legislador si la materia es objeto de una reserva de ley. Son supuestos en los que la Constitución viste con el ropaje de un permiso la decisión sobre si introducir o no poder público en una determinada materia, creando o no la institución, o regulando o no la relación sociopolítica que constituye su objeto. El silencio al respecto únicamente significa que tal situación jurídica no existe, consecuencia también querida por la Constitución, pues la permite. En último término, la norma constitucional permisiva tolera la existencia en el ordenamiento jurídico de dos posibles situaciones jurídicas, incluso antagónicas, y tan sólo establece que la opción por una u otra le compete a otro ${ }^{8}$.

No obstante, resulta posible que ciertos silencios legislativos respecto de un permiso constitucional deriven en una omisión inconstitucional. Mientras el uso del permiso sea competencia exclusiva del legislador (reserva de ley), el silencio de éste o de sus leyes (omisión absoluta y relativa respectivamente) debe interpretarse como un no uso de ese permiso. La situación jurídica permitida por la Constitución no existe porque el competente para decidir sobre su existencia actual, en este caso el legislador, no lo ha hecho. El permiso permanece, no obstante, pues su silencio, sea absoluto, sea relativo, ni impide ni prohíbe en modo alguno su empleo futuro cuando el legislador lo estime oportuno. El legislador no ha dispuesto con su silencio del permiso en sí mismo considerado, que de ser así, es cuando ese silencio se toma en omisión inconstitucional, pues el legislador ha dispuesto de la posibilidad misma de que exista lo querido por la Constitución, impidiendo al legislador futuro crear la situación jurídica constitucionalmente permitida. De lo que

$7 \quad$ Véase el artículo de Lerche, P. „Das Bundesverfassungsgericht und die Verfassungsdi rektiven. $\mathrm{Zu}$ den „nicht erfullten Gesetzgebungsaufträgen“, 1965, pp. 341 y ss. pp. 371 y 372.

8 Sobre todas estas preguntas consúltese las obras de Hesse, K. „Grundzüge des Verfassungsrechts der Bundesrepublik Deutschland“. C.F. Müller (19 edic.), Heidelberg, 1993. 1 secc. III; y Rainer Wahl, Der Vorreng der Verfassung, ob. Cit., pp. 502 a 508. 
puede disponer el legislador es de la existencia de la situación jurídica que la Constitución permite que exista en el ordenamiento jurídico, y mientras no se pronuncie, ningún sujeto del ordenamiento puede sustituirle en esa decisión. Ahora bien, el permiso constitucional se vería contrariado por una norma implícita en el silencio legislativo que suponga prohibir el empleo por el legislador futuro de ese permiso constitucional.

La previsión constitucional de permisos jurídicos no es insignificante.

Téngase en cuenta que, si esa misma situación no es, ni siquiera, objeto de un permiso constitucional, el legislador puede disponer de ella incluso para prohibirla9. La función del permiso constitucional sobre la existencia de esa situación es la de inmunizarla frente a la prohibición legislativa. Con el permiso se está diciendo que su existencia no es contraria a la Constitución, pero sí lo es disponer de la propia posibilidad de que exista. Parece evidente que, si el silencio lo es del legislador (omisión absoluta), con su abstención únicamente puede impedir la existencia actual de la situación jurídica permitida por la Constitución. Pero este efecto está previsto, en principio, por la norma constitucional permisiva.

Ese silencio, si lo es de la ley (omisión relativa), pues de un silencio del legislador (omisión absoluta) difícilmente podrá deducirse una norma prohibitiva, puede convertirse en una omisión inconstitucional en el caso de que signifique la prohibición de la existencia actual o futura en el ordenamiento jurídico de la situación jurídica permitida por la Constitución. La situación jurídica resultante es justamente la no querida por la Constitución. Con ese silencio de la ley, el legislador ha dispuesto del permiso mismo, pues, no es que con él impida la existencia actual de la situación jurídica permitida por la Constitución, lo que equivale a un no uso del permiso; sino que sanciona la existencia actual y futura de esa situación (por ejemplo, si la ley que regula los departamentos, lo hace de tal modo que prohíbe la existencia de agrupaciones municipales distintas a ellas).

Lo mismo puede suceder si la Constitución no acompaña al permiso con la determinación de quién puede hacer uso de él. La decisión última sobre la existencia de esa situación jurídica le corresponde a quien resulta

Esta afirmación aleja los silencios legislativos y su control del sumamente problemático concepto de, fraude de constitución. Una categoría vidriosa desde el punto de vista jurídico. Véase de Mortati. "Instituzioni di Diritto Pubblico", vol. II. CEDAM, Padova, 1976 (9a edic.), pp. 1413 y 1414. 
investido de esa competencia por el juego de las reglas de validez del sistema de fuentes definido por la Constitución. Sólo un silencio de la ley (omisión relativa) puede devenir en una omisión inconstitucional cuando de ese silencio se deduzca una norma implícita que prohíba la existencia de la situación, pues, si la impide, incluso en el caso de un silencio del legislador (omisión absoluta), tan sólo somete la eficacia de la decisión del otro sujeto del ordenamiento que pretende hacer uso del permiso a la anuencia del legislador. Esto no vulnerará la Constitución mientras esa actitud del legislador no contradiga las reglas de validez del sistema de fuentes. Precisamente el silencio legislativo vulnera la reglas de validez, si la competencia para hacer uso del permiso es atribuida por la Constitución a un sujeto del ordenamiento distinto al legislador y el silencio del legislador o de la ley impide (y si es un silencio de la ley incluso puede prohibir) el ejercicio de esa competencia.

En este caso, esa aptitud contraria del silencio legislativo vulnera la norma constitucional que atribuye la competencia a otro sujeto distinto al legislador.

2.

\section{DESARROLLO LEGISLATIVO DE NORMAS CONSTITUCIONALES, NORMAS CONSTITUCIONALES DE CONFIGURACIÓN LEGAL Y MANDATOS CONSTITUCIONALES}

Están también aquellas situaciones jurídicas cuya existencia le es indisponible al legislador o a cualquier otro poder del estado, bien porque la norma constitucional que las prevé goza de eficacia directa en lo tocante a su existencia, sin excluir una concreción legislativa de la misma (esté prevista expresa o tácitamente por la Constitución esta concreción, esto es lo de menos), bien porque la Constitución manda que exista tal situación jurídica, aunque su efectiva existencia dependa de la creación de normas para el caso por los poderes del estado, o sólo por el legislador si la situación es objeto de una reserva de ley. Ambos supuestos coinciden en la indisponibilidad para el legislador de la existencia de la situación jurídica. En lo que resta las diferencias son importantes. En un caso, la competencia para concretar lo querido por la Constitución es un permiso, y en él otro, es un mandato ${ }^{10}$.

10 Mortati C. (1972). Appunti per uno studio sui rimedi giurisdizionali contro comportamenti omissivi del legislatore. En Raccolta di ScrittiA, T. III, Problemi di Diritto Pubblico nell'attuale esperienze costituzionale repubblicana. Milan, 
En el primero de ellos la norma constitucional posee un resto de eficacia directa, pues la situación debe existir con independencia de la intervención del legislador. En punto a la existencia de una situación jurídica determinada en el ordenamiento jurídico, la norma constitucional es autoaplicativa, en términos similares a los expuestos arriba para los casos de normas constitucionales autoaplicativas. En el caso que ahora nos ocupa, el silencio sólo puede significar que la situación jurídica existe en el ordenamiento jurídico, aunque con contornos concretos aún difusos a falta de la intervención posterior del sujeto del ordenamiento jurídico competente para ello. En estos casos, tanto si el uso del permiso para concretar el modo de existencia de la situación jurídica querida por la Constitución es objeto de una reserva de ley, como si no se determina quién es su destinatario, un silencio del legislador (omisión absoluta) sobre el particular no puede interpretarse como una disposición sobre la existencia misma de esa situación jurídica ${ }^{11}$. Esta tendrá los contornos que resulten de la aplicación directa de la norma constitucional (por ejemplo, un derecho fundamental que debe existir y existe aunque el legislador aún no haya regulado su ejercicio o lo haya desarrollado de acuerdo con preceptos como el art. 53 CPC). En la medida en que del silencio legislativo no puede deducirse una norma implícita que impida o prohíba la aplicación directa en ese extremo de la norma constitucional, no habrá omisión inconstitucional, ni absoluta ni relativa, ya que en esta última el silencio de la ley también debe suplirse con la aplicación directa de la Constitución.

Si la Constitución no atribuye la competencia para la mencionada concreción a ningún sujeto determinado del ordenamiento jurídico, la determinación de quién pueda hacerlo, debe extraerse de las reglas de validez del sistema de fuentes. El silencio del legislador podrá impedir que los otros sujetos hagan uso del permiso, lo que no es contrario a la Constitución mientras no implique una lesión de tales reglas del sistema de fuentes, pero no podrá impedir que se desplieguen los efectos directos de la norma constitucional. Sólo si la Constitución ha atribuido a un sujeto

Italia: Giuffré. Otto \& Pardo I. (1993). Derecho Constitucional. Sistema de fuentes. Barcelona, España: Ariel. Sustein C. (1993). The Partial Constitution. Cambridge, Massachusett: Harvard Uni. Press.

11 Ahumada, M. A. (1991). El Control de Constitucionalidad de las Omisiones Legislativas. Madrid, España: Revista del Centro de Estudios Constitucionales. 
jurídico distinto del legislador la competencia para hacer uso del permiso de concreción de la situación jurídica en el ordenamiento jurídico, ese silencio del legislador o de la ley pueden devenir en sendas omisiones inconstitucionales si lesionan el sistema de fuentes bien impidiendo, o prohibiendo si es una omisión relativa, el ejercicio del permiso por el sujeto competente.

El otro caso es aquel en el que la existencia efectiva de la situación depende de la creación de normas por los poderes del estado, y no sólo sus contornos específicos en el ordenamiento jurídico. Pero esa creación normativa de la que depende la existencia de la situación jurídica es objeto de un mandato constitucional, y no de un permiso. Resulta evidente, pues, que la norma constitucional no es autoaplicativa en lo referente a la existencia de la situación jurídica por ella querida, es una norma sin eficacia directa. Es precisamente en estos supuestos en los que la presencia o ausencia de un plazo para legislar cobra un especial significado.

El silencio de los poderes del estado, y en particular del legislador si hay reserva de ley, puede disponer de la existencia de esa situación jurídica, ya que su actividad sí es necesaria para que exista. Si hay silencio ya no cabe aseverar que la situación jurídica existe en efecto, aunque no definida en sus contornos precisos, como consecuencia de la aplicación directa de la norma constitucional. Si hay silencio, la situación jurídica querida por la Constitución no existe ${ }^{12}$. Si la norma constitucional no establece plazo alguno para ejecutar la orden constitucional, el silencio del legislador (omisión absoluta) sobre la existencia de la situación jurídica no impide su posterior existencia, y tampoco la prohíbe, como es obvio. En este sentido, el silencio sólo podría transformarse en omisión inconstitucional, si la situación jurídica así creada no consiste en la simple inexistencia de lo querido por la Constitución (lo que no es contrario a la Constitución de suyo, puesto que el cumplimiento del deber constitucional carece de plazo para ser ejecutado; es el caso de las normas constitucionales que prevén la creación de órganos o instituciones del Estado), sino en la existencia de una situación que representa justo lo contrario a lo querido por la Constitución (piénsese en el supuesto del derecho de asilo del art. 36 CPC) o si lesiona cualquier otro precepto constitucional (por ejemplo, el principio de igualdad). Aquí

12 Seufert, L. (1969). Die nicht erfüllten Gesetzgebungsgebote des Grundgesetzes und ihre verfassungsgerichtliche Durchsetzung. Ein Beitrag zum Problem gesetzgeberischen Unterlassens.Würzburg, Alemania: Dissertation Doctoral. 
sí que no sólo una prohibición, sino también el simple impedimento de la existencia de la situación jurídica querida por la Constitución pueden provocar la existencia de una contraria a la Constitución ${ }^{13}$.

Quizá sean estos supuestos, los de las normas constitucionales imperativas, los que plantean mayores dificultades. Parece obvio que si son normas imperativas, la Constitución ordena algo a los poderes del estado destinatarios de esa norma imperativa. La ausencia de un plazo para ejecutar el mandato parece alterar el contenido normativo del citado tipo de normas en un simple programa cuya ejecución queda al destino del legislador. Sin embargo, esta interpretación no es de recibo si se desea preservar la supremacía normativa de la Constitución. Pero tampoco lo es sostener que dicha imperatividad se manifiesta dotando de eficacia directa a la norma constitucional imperativa sin más, a pesar de no haber sido ejecutada. No hay tal eficacia directa porque la situación jurídica constitucionalmente prevista, al contrario que en el caso de las normas constitucionales que están abiertas al desarrollo legal, necesita de la mediación legislativa para existir. Ahora bien, a diferencia de un permiso constitucional, la existencia de esa situación es un deber inexcusable. Por tanto, ni hay norma constitucional directamente aplicable, ni son posibles diversas situaciones distintas a la constitucionalmente permitida, sino que sólo puede existir una, la fijada en la norma constitucional imperativa, pero que carece de los contornos precisos para surtir efectos inmediatos sin la previa intervención del legislador o de otro poder del estado habilitado al efecto. De la norma constitucional imperativa cabe deducir una norma que, al tiempo que impone la existencia de la situación jurídica por ella prevista, prohíbe la existencia de cualquier otra que la contradiga. Si el silencio legislativo propicia la existencia de esa situación jurídica contraria, deberá negársele todo efecto jurídico a la situación contraria a la Constitución resultante del silencio legislativo. En esto radica el mínimo vinculante y eficaz de estas normas constitucionales, aunque carezcan de desarrollo normativo infraconstitucíonal. Ese mínimo

13 Bastida, F. (1991). Constitución, Soberanía y Democracia. Madrid, España: Revista del Centro de Estudios Constitucionales. Kelsen, H. (1960). Das Problem der Souveränität. Tübingen, Alemania: Scientia Verlag Aalen. Hauriou, A. (1971). Derecho Constitucional e Instituciones Políticas. Barcelona, España: Ediciones Ariel. Kuhn, H. (1979). El Estado. Madrid, España: Editorial Rialp. Rousseau, J.J. (1983). El Contrato Social. Madrid, España: Editorial Sarpe. Younes, D. (1994). Derecho Constitucional Colombiano. Bogotá, Colombia: Ediciones Jurídicas Gustavo Ibáñez. 
es la manifestación de la supremacía constitucional, que vincula a todos los sujetos del ordenamiento jurídico, en particular a los jueces ${ }^{14}$.

Como ya se ha mencionado, puede ocurrir que un silencio permita que otras normas explícitas regulen una situación jurídica de manera contraria a la Constitución. Puede ser el caso de las normas preconstitucionales que son aplicables a falta de normas postconstitucionales. El silencio no es fuente de producción de esas normas explícitas porque su validez no deriva del silencio; éste es sólo un hecho contemplado por el constituyente que permite su aplicabilidad. Del mismo modo que no incurre en omisión inconstitucional el legislador posterior en el tiempo al legislador que promulga una ley que ha sido declarada inconstitucional, si con su silencio ha conservado una situación contraria a la Constitución (la creada por la ley anterior declarada inconstitucional). El silencio del legislador postconstitucional en el primer caso, y del posterior en el tiempo en el segundo, no es la fuente de producción, y por ello de validez en primer grado, de las normas explícitas que regulan ciertas materias, sino, a lo sumo, el supuesto de hecho que permite su aplicabilidad a esa materia. Por ello, la situación jurídica contraria a la Constitución no es provocada por el silencio, sino por aquella ley, preconstitucional o postconstitucional según el caso. De todo ello cabe deducir que sólo se producen situaciones jurídicas contrarias a la Constitución que transforman el silencio del legislador en una inconstitucionalidad por omisión cuando la validez de esa situación, es decir, de su régimen jurídico, deriva de la validez de la norma implícita aplicable al caso. Si son normas explícitas las aplicables, el silencio actúa, a lo sumo, de supuesto de hecho que condiciona su aplicabilidad.

Un caso particular es el del reglamento independiente que regula una materia aún no regulada por el legislador. La posible inconstitucionalidad en la que puede incurrir ese reglamento no puede derivarse de la posible inconstitucionalidad del silencio legislativo que viene a llenar, y menos aún puede concebirse la existencia de ese reglamento declarado inconstitucional como la prueba de la inconstitucionalidad del silencio del legislador que ha permitido su existencia. Ni tan siquiera en los supuestos en los que la materia objeto de ese reglamento independiente lo es a su vez de una reserva dé ley. El silencio del legislador no da cobertura en ningún caso

14 Bachof, O. (1979). "Grundgestez und Richtermacht". En Wege zum Rechtsstaat. Ausgewáhlte Studien zum óffentlichen Recht. Königstein, Alemania: Athenaum, pp. 172 y ss. 
al reglamento independiente, toda vez que si es así, dejaría de serlo. Es el preciso precepto constitucional que atribuye esa potestad al Gobierno quien ofrece la cobertura normativa para ello. Si la materia regulada por el reglamento es objeto de una reserva de ley, ese reglamento es inconstitucional precisamente por invadir un ámbito reservado a la ley. El silencio del legislador ni da cobertura, dotándole de una validez que la propia Constitución le niega, a ese reglamento, ni es el supuesto de hecho que la Constitución contempla como causa de la existencia y de la aplicabilidad del reglamento independiente. No es muy distinto el supuesto de materias que no están reservadas a la ley. De nuevo, el silencio del legislador no es la norma que da cobertura a ese reglamento, pues lo es la Constitución. A lo sumo, ese silencio puede entenderse como condición necesaria para la válida existencia de tal reglamento ${ }^{15}$.

\section{CONCLUSIONES}

Recapitulando lo dicho, son cuatro los tipos de normas constitucionales que aquí hemos analizado. Las normas constitucionales autoaplicativas, los permisos constitucionales, las normas constitucionales que están abiertas a un posterior desarrollo normativo y las normas constitucionales imperativas. Tanto las normas constitucionales autoaplicativas como las abiertas al desarrollo normativo poseen eficacia directa en lo tocante a la existencia de la situación jurídica por ellas regulada, de tal manera que el silencio legislativo carece de relevancia, de modo que no es el silencio legislativo el que vulnera la Constitución, sino quien pretenda valerse de él para distorsionar aquella eficacia directa. El silencio legislativo cobra relevancia en los casos en los que la norma jurídica querida por la Constitución puede quedar de un modo u otro a disposición del legislador (o sujeto competente en su caso). Esto sucede con los permisos constitucionales y las normas constitucionales imperativas. En el primer caso, la Constitución permite al legislador optar entre dar existencia o no a cierta situación jurídica, pero le prohíbe disponer del permiso constitucional mismo. El silencio legislativo no se transforma en una omisión inconstitucional si únicamente impide la existencia de la situación jurídica constitucionalmente permitida, pues tal resultado también está tolerado por la Constitución. Cosa distinta es si el

15 García, E. (1979). La Lucha Contra las Inmunidades el Poder en el Derecho Administrativo. Madrid, España: Civitas. 
silencio legislativo supone una prohibición de la existencia de esa situación jurídica (lo que sólo es posible en los casos del silencio de la ley), pues se está negando el permiso mismo, lo que transforma el silencio en una omisión inconstitucional. En el segundo caso, la Constitución no permite al legislador optar, le impone la existencia de una situación jurídica determinada y además le ordena su regulación. Así pues, el silencio del legislador que impida, o el silencio de la ley que impida o prohíba la existencia de dicha situación, se transforman en omisiones inconstitucionales. En estos casos de normas constitucionales permisivas o imperativas, el mínimo constitucionalmente obligatorio de estas normas se manifiesta en la negación (invalidación) de toda eficacia jurídica a la norma implícita en el silencio legislativo que tenga como consecuencia impedir o prohibir, según el caso, la existencia de la situación jurídica querida por la Constitución.

\section{REFERENCIAS}

Aguiar, L. (1987). El Tribunal Constitucional y la función legislativa: el control del procedimiento legislativo y de la inconstitucionalidad por omisión, Revista de Derecho Político, N.0 24, pp. 9 y ss.

Alchourron \& Bulygin. (1971). Normative Systems, Springer, Wien/New York.

—. (1974). Introducción a la metodología de las ciencias jurídicas y sociales. Astrea, Buenos Aires, pp. 161 y ss.

—. (1981). The Expressive Conception of Normsen New Studies. In Hilpinen (edit.), Deontic Logic. Norms, Actions, and The Foundations of Ethics, (pp. 95 y ss). Boston, London: Reidel, Dordrecht.

Ahumada, M. A. (1991). El Control de Constitucionalidad de las Omisiones Legislativas, Revista del Centro de Estudios Constitucionales, No 8, (pp. 169 y ss).

Alexy, R. (1983). Theorie der juristischen Argumentation. Die Theorie des rationale Diskurses als Theorie der juristischen Begründung. Frankfurt: Ed. Suhrkamp.

—. Theorie der Grundrechte, (1986). Frankfurt: Ed. Suhrkamp.

- (1947). Rechtssystem und praktische Vernunft, (pp. 405 y ss). Rechtstheorie, Bd. 18, Hf.4.

Aragón, M. (1978). La reserva reglamentaria en el proyecto constitucional y su incidencia en las relaciones Parlamento-Gobierno. En Ramírez (edit.), El control parlamentario en las democracias pluralistas (El proceso constitucional español) (pp. 297 y ss.), Barcelona: Labor. 
- (1986). Sobre las nociones de supremacía y supralegalidad constitucional, Revista de Estudios Políticos, No 50, pp. 9 y ss.

- (1987). El control como elemento inseparable del concepto de constitución, Revista Española de Derecho Constitucional, No 19, pp. 15 y ss.

—. (1988). Comentarios a las Leyes políticas, T. XII, Madrid: Edersa,

-_- (1995). Constitución y control del poder. Introducción a una teoría constitucional del control, Buenos Aires: Ediciones Ciudad Argentina.

Atienza, M. (1986). Sobre la analogía en el Derecho. Ensayo de análisis de un razonamiento jurídico. Madrid: Civitas.

Ackerman, Rosenkrantz, Balbin \& otros. (1991). Fundamentos y alcances del control judicial de constitucionalidad. Centro de Estudios Constitucionales (Cuadernos y Debates No. 29), Madrid, España.

Aguiar, L. (1987). El Tribunal Constitucional y la función legislativa: El control del procedimiento legislativo y de la inconstitucionalidad por omisión, Revista de Derecho Publico, No. 24, pp. 9 y ss. Madrid, España.

Alonso, E. (1988) El control por el Tribunal Constitucional del sistema español de fuentes del derecho a través del articulo 24 de la Constitución (Comentario sobre diversas lineas jurisprudenciales del Tribunal Constitucional sugerido por la lectura de la sentencia 23/1988, de 22 de Febrero 1987”, Revista Española de Derecho Constitucional, No. 24, pp. 191 y ss. Madrid, España.

Anschütz, G. (1969) Die Verfassung des Deutschen Reiches vom II. August 1919, Wissenschaftliche Gesellschaft (reimp. de la 14a. edic. de 1933), Darmstadt, Alemania.

Anzoa, A. (1992). Nuove technique decisorie della Corte Constituzionale, Giurisprudenza Costituzionale, fasc. 4, pp. 3199 y ss. Turin, Italia.

Bachof, O. (1979) Grundgestez und Richtermacht. Publicado en Wege zum Rechtsstaat. Ausgewáhlte Studien zum óffentlichen Recht. Athenaum, Königstein/Ts., pp. 172 y ss.

Bacigalupo, E. (1983). La garantía del principio de legalidad y la prohibición de la analogía en el derecho penal. Anuario de Derechos Humanos, $\mathrm{N}^{\circ} 2$, pp. 11 y ss.

Balaguer, F. (1990). Conflictos normativos entre el derecho estatal y el derecho autonómico. Revista de las Cortes Generales, $\mathrm{N}^{\mathrm{o}} 19$, pp. 85 y ss.

- La interpretación del derecho autonómico y la aplicación supletoria del derecho estatal, (1991). Revista de Administración Pública, $\mathrm{N}^{\circ}$ 124, pp. 95 y ss.

Baño, J. M. (1988). La distinción entre derecho fundamental y garantía institucional en la Constitución española. Revista Española de Derecho Constitucional, $\mathrm{N}^{\circ}$ 24 , pp. 155 y ss. 
- (1991). Los límites constitucionales de la potestad reglamentaria (Remisión normativa y reglamento independiente en la constitución de 1978). Madrid: Civitas.

Barbey, G. (1986). Bundesverfassungsgericht und einfaches Gesetz. De Gruyter, Berlin/New York.

Bastida, F., (1990). La libertad de antena. El derecho a crear televisión. Barcelona: Ariel.

—. (1991). Constitución, soberanía y democracia, Revista del centro de Estudios Constitucionales, $\mathrm{N}^{\circ} 8$. pp. 9 y ss.

Baumlin, R. (1954). Die rechtsstaatliche Demokratie. Eine Untersuchung der gegenseitigen Beziehungen von Demokratie und Rechtsstaat. Polygraphischer V., Zürich.

Blanco, R. (1994). El valor de la Constitución. Separación de poderes, supremacía de la ley y control de constitucionalidad en los origenes del Estado liberal. Madrid: Alianza.

—. «La supremacía de la ley y sus consecuencias en la teoría constitucional de la Revolución francesa», Anuario de Derecho Constitucional y Parlamentario, $\mathrm{N}^{\circ} 6,1994$, pp. T7 y ss.

Badura, P. (1982). Die verfassungsrechtliche Pflicht des gesetzgebenden Parlaments zur "Nachbesserung" von Gesetzsen, en Saatsorganisation und Staatfunktionen im Wandel. Muller/Rhinow/Schmid/Wildhaher (Hrsg.) pp. 481 y ss. Helhin und Lichtenhahn. Basel/Frankfurt.

Bettermann, K. A. (1982). Richterliche Normenkontrolle als negative Gesctzgebung?. Deutsche Verwaltungsblatt. Hf. I. pp. 91 y ss.

—. (1986). Die Verfassungskonforme Auslegung, C. F. Muller. Heidelberg.

Blasco, M. del C. (1995). La sentencia en la Cuestion de inconstitucionalidad. Barcelona: Bosch.

Bocanegra, R. (1982). El valor de las sentencias del Tribunal Constitucional, Madrid: Instituto de Estudios de Administración Local.

- (1991). Sobre el alcance objetivo de las sentencias del Tribunal Constitucional. En Estudios sobre la Constitución Española. Homenaje a García de Enterría. Vol. I, (pp. 508 y ss.). Madrid: Civitas.

Bockenforde, C. (1966). Die sogenannte Nichtigkeit verfassungswidriger Gesetze. En Eine Unrersuchung über Inhalt und Folgen der Rechtsstaatskontrollenstcheidungen des Bundesverfassungsgerichts, Berlin: Duncker \& Humblot.

Bon, Casalta, Lobo 6 otros (1989). La justice constitucionnelle au Portugal, Paris: Economica, 
Borrajo, Iniesta, Diez, Gimenez, Fernandez \& Farreres, (1995). El derecho a la tutela judicial y el recurso del amparo. Una reflexión sobre la jurisprudencia constitucional. Madrid: Civitas,

Buchholz, D. H. (1995). Der Richter als Ersatzgesetzgerber, Zeirschrift für Rechtspolitik, Hf. 4, (pp. 149 y ss.), Berlin.

Calvo, M.(1995). Naturaleza jurídica de la potestad reglamentaria y consecuencias de la pasividad administrativa, Revista de Administración Publica, $\mathrm{N}^{\circ} 137, \mathrm{pp}$. 239 y ss.

Carré, R., (1962). Contribution a la Théorie Gánérale de l'État, spécialment d'aprés les données fournies par le Droit constitutionnel francaise. Centre Nationale de la Recherche Scientifique. (reimp. edic. 1922).

_. (1984). La Loi, expression de la volonté générale. (reimp. edic. 1931), Paris: Economica.

Cascajo, J. L., (1981). Aproximación al tema de las funciones del Tribunal Constitucional. En El Tribunal Constitucional, Vol. 1, (pp. 631 y ss.) Madrid: Instituto de Estudios Fiscales,

Cobreros, E., (1988). Reflexión general sobre la eficacia normativa de los principios constitucionales rectores de la política social y económica del Estado. Revista Vasca de Administración Pública, № 19, pp. 27 y ss.

Cappelletti, M. (1970) Il controllo giudiziario di costituzionalita delle leggi nel diritto Comparato, Milano: Giuffré.

—. (1984). Giudici Legislatori? Milano: Giuffré.

Cardoso, J. M. (1992). A jurisdicao constitucional em Portugal, ( $2^{\mathrm{a}}$ edic. rev. y actual), Portugal: Almedina, Coimbra.

Celotto, A. (1995). Corte costituzionale ed eccesso di potere legislativo, Giurisprudenza Coostituzionale, fasc. 5, pp. 3724 y ss.

Crisafulli, V. (1978). La Corte costituzionale ha ventanni. En Occhiocupo (a cura). La Corte Costituzionale tra norma giuridica e realta sociale, (pp. 69 y ss.). il Mulino.

—. (1964). Disposizione (e norma), Enciclopedia dil Diritto, Vol. XIII pp. 196 y ss.

Cruz, P. (1987). La formación del sistema europeo de control de constitucionalidad (1918-1939), Madrid: Centro de Estudios Constitucionales.

- (1994) Sobre el amparo, Revista Española de Derecho Constitucional. No. 41, pp. 9 y ss.

Cruz, López, Jimenez \& Pérez. (1992). Los procesos Constitucionales. Segundo simposio de Derecho Constitucional (Sevilla. 27 y 28 de septiembre de 1991), Centro de Estudios Constitucionales (Cuadernos y Debates No. 41), Madrid. 
Chryssogono, K. (1987). Verfassungsgerichtsbarkeit und Gesetgebung. Zur Methode der Verfassungsinterpretation bei der Normenkontrolle, Berlin: Duncker \& Humblot.

Díez, L.M., (1985). Constitución, Ley, Juez. Revista Española de Derecho Constitucional, $\mathrm{N}^{\circ} 15$. (pp. 9 y ss).

Denninger, E. (1966) Verfassungsauftrag und gesetzgebende Gewalt. Juristen Zeitung, Hf. 23/24, (pp. 767 y ss.). Berlin: Duncker \& Humblot,

Detterbeck, S. (1990) Subsidiarität der Verfassungsbeschwerde nach Art. 93 Abs. l Nr.4a GG auch bei norrnativem Unterlassen?, Die offentliche Vemalwng, Hf. 20, (pp. 858 y ss.) Berlin.

Dietlein, J. (1992). Die Lehre von den grumdrechtlichen Schutzpflichten, Berlin: Duncker \& Humblot.

D'orazio, G. (1992). Le sentenze costituzionale additive, la esaltazione e contestazione, Revista Trimestrale di Diritto Pubblico, No. I, pp. 61 y ss.

Eberle. C.E. (1984). Gesetzvorbehalt und Parlamentsvorbehalt-Erkenntnisse und Folgerung aud der jüngeren Verfassungsrechtsprechung. Die Öffentliche Verwaltung. Hf. 12. (pp. 485 y ss). Heidelberg.

Erichsen, H.U. (1976). Die Einstweilige Anordnung. En Bundesverfassungsgericht und Grundgesetz. Festgabe aus Anlass des 25 jährigen Bestehen des Bundesverfassungsgericht, Starck (Hrsg.), J. C. B. Mohr, Tübingen.

Ezquiaga, F. J. (1987) La argumentacion en la justicia constitucional española, Instituto Vasco de Administracion Publica, Oñate.

_- Diez años de fallos constitucionales (Sentencias interpretativas y poder normativo del Tribunal Constitucional). Revista Vasca de Administracion Publica, No. 31, 1991, pp. 117 y ss.

Fernández, J. J., (1995). La inconstitucionalidad por omisión en Brasil. Revista Vasca de Administración Pública, N 42, pp. 207 y ss.

Fernández, F. (1994). Los nuevos desafios de nuestro tiempo para la proteccion jurisdiccional de los derechos, Revista Vasca de Administracion Publica, No. 39 , pp. 25 y ss.

Figueruelo, A. (1993). La incidencia positiva del Tribunal Constitucional en el Poder Legislativo. Revista de Estudios Politicos, No. 81, pp. 47 y ss, Madrid.

Forsthoff, E. (1975) El Estado de la sociedad industrial, (trad. Lopez Guerra/ Nicolas Muñiz). Madrid: Instituto de Estudios Politicos,

Friesenhahn, E. (1963). Die Verfassungsgerichtbarkeit in der Bundesrepublik Deutschland, Heymanns, Köln/Berlin/Bonn/München. 
Galeotti, S. (1950). La garanzia costituzionale (presupposti e concetto). Milano: Giuffré.

—. Introduzione alla teoría dei controlli costituzionali. (1963). Milano: Giuffré, García, E., (1981). Legislación delegada, potestad reglamentaria y control judicial. Madrid: Tecnos.

_. La posición del Tribunal Constitucional en el sistema español. Posibilidades y perspectivas, (1981). Revista Española de Derecho Constitucional, N 1. pp. 35 y ss.

—. (1985). La Constitución como norma y el Tribunal Constitucional, Madrid: Cívitas.

- (1989). Un paso importante para el desarrollo de nuestra justicia constitucional: la doctrina prospectiva de las leyes inconstitucionales,. Revista Española de Derecho Administrativo, $\mathrm{N}^{\circ}$ 61, pp. 5 y ss.

Gomes, J. J. (1982). Constitucao dirigente e vinculaca do legislador. Contributo para a compreensao das normas constitucionais programáticas. Coimbra Editora.

— (1993). Tomemos a seério o siléncio dos Poderes Públicos. O díreito a emanaçao de normas juridicas e a proteccao judicial contra os omissoes normativas. En $A s$ garantías do cidadao ná justica, (pp. 309 y ss.) Sao Paulo: Saraiva.

—_. (1995). Direito Constitutucional, (6. edic.), Coimbra: Almeduna,

- - (1995). Revisar la/o romper con la Constitución dirigente? Defensa de un constitucionalismo moralmente reflexivo. Revista Española de Derecho Constitucional, $\mathrm{N}^{\circ}$ 43. pp. 9 y ss.

García, J. (1985). El control parlamentario del gobierno en el ordenamiento español. Madrid: Publicaciones del Congreso de los Diputados.

García, E. (1992) Control del acto politico y garantia de los derechos fundamentales. El derecho a un proceso sin dilaciones indebidas. A propósito de la STC 45/1990 de 15 de marzo. Revista Española de Derecho Constitucional, No. 36, 1992, pp. 277 y ss.

Garrido, F. (1994). A vueltas con la responsabilidad del Estado Legislador. Revista Española de Derecho Administrativo, No. 81, pp. 111 y ss. Madrid.

Gascon, M. (1994). La Justicia Constitucional: entre legislación y jurisdicción. Revista Española de Derecho Constitucional, No. 41, pp. 63 y ss. Madrid.

Gerber, C. F. V. (1971) Diritto Pubblico. Milan: Giuffré,

Gómez, M. (1994). Derechos fundamentales y omision legislativa: de nuevo sobre la televisión. (Lectura de la STC 11/1994, de 31 de enero de 1994), Revista Española de Derecho Administrativo. No. 84, pp. 629 y ss.

Gotz \& Starck. (1985). Die öffentliche Verwaltung zwischen Gesetzgebung und richterliche Kontrolle, C. H. Beck, München. 
Grimm, D. (1983). La Constitucion como fuente del Derecho, en Las Fuentes del Derecho. Primeras jornadas juridiques de Lleida (13-14 de mayo de 1983). Anuario de Ia Facultad de Derecho. Baratta/Grimm/Rubio y otros. Estudio General de Lleida. Lleida. Barcelona.

—. (1991). Die Zukwnft der Verfassung. Frankfurt: Suhrkamp, Hauriou, M., (1923) Précis de Droit constitutionnel, Paris: Sirey.

Hesse, K., (1983) Das Grundgestz in der Entwicklung der Bundesrepublik Deutschland: Aufgabe und Funktion der Verfassung. En Handbuch des Verfassungsrechts. (pp. 3 y ss.). Benda/Maihofer/Vogel (Hrsg.), de Gruyter, Berlin, New York.

- (1993). Grundzüge des Verfassungsrechts der Bundesrepublik Deutschland, C. F. Mü- ller, Heidelberg, (19 ed.)

Hövel, M. van den. (1990). Zuläsigkeits-und Zulassungsprobleme der Verfasungsbeschewerde gegen Gesetze. Duncker \& Humblot, Berlin.

Haberle, P. (1976). Verfassungsgerichtsbarkeit, Wissenschaftliche Buchgesellschaft, Darmstadt.

Haenel, A. (1968) Das Gesetz im formellen und materiellen Sinne. Wissenschaftliche Buchgesellschaft. Darmstadt.

Hein, P. E. (1988). Die Unvereinbarerklärung verfassunhswidriger Gesetze durch das Bundesverfassungsgericht, Grundlagen, Andwendungsbereich, Rechstfolgen. Nomos, Baden-Baden.

Henke, W. (1964). Verfassung, Gesetz und Richter. Das Normenkontrollverfahren, Der Staat, Hf. 4, (pp. 433 y ss.), Heidelberg.

Henkin, L. (1976) Is There a "Political Questions" Doctrine?, Yale Law Journal, Vol. 85, (pp. 597 y ss.), New Heaven, CT.

Hernández, R. (1994). La tipología de las sentencias constitucionales con efectos fiscales. Revista Española de Derecho Constitucional, No. 41, pp. 225 y ss. Madrid.

Herzog, R. (1965). Die Vollstreckung von Entscheidungen des Bundesverfa ssungsgerichts, der Staat. C.H. Beck, München.

—. Das Bundesverfassungsgericht und die Anwendung einfachen Gesetzrechts, C.H. Beck, München.

Jellinek, G., (1964). Gesetz und Verordnung. Staatsrechtliche Untersuchungen auf rechtsgeschichtlicher und rechtsvergleichender Grundlage. Scienta Verlag Aalen, Tübingen, (reimp, ed. 1887).

—. (1966). Allgemeine Staatslehre. Max Ggehlen, Bad Homburg/Berlin/Zürich. (reimp. de la 5. Ed., reimp. de la 3. ed. de 1921). 
- (1979). System der subjektiven öffentlichen Rechte. Scienta Verlag Aalen, Tübingen. (reímp. 2. ed. 1919).

Jiménez, J. (1987). La garantía constitucional del secreto de las comunicaciones, Revista Española de Derecho Constitucional, N²0. pp. 35 y ss.

- Qué es lo básico? Legislación compartida en el Estado autonómico., (1989) Revista Española de Derecho Constitucional, a.0 27. pp. 39 y ss.

Kelsen, H. (1960). El problema de la Soberanía, Scienta Aalen, Tübingen. (reimp. de la 2. ed., 1928).

-. (1976). Reine Rechtslehre, Franz Deuticke, Wien. (2. reimp. de la 2. ed. 1960).

-. (1979). Teoría general del Derecho y del Estado, UNAM, México. (2. reimp. de la 2. ed. 1958, trad. García Máynez).

—. (1979). Allgemeine Theorie der Normen, Manz, Wien.

Kuhn, H. (1979). El Estado. Madrid: Editorial Rialp.

Kagi, W. (1946). Die Verfassung als rechtliche Grundordnung des Staates. Untersuchungen über dei Entwicklungstendenzen im modernen Verfassungsrecht. Polygraphischer V., Zürich.

- Rechtsstaat und Demokratie, Antinomie und Synthese, en Der bürgerliche Rechsstaat, Tohidipur (Hrsg.). Suhrkamp, Frankfurt.

Kalkbrenner, H. (1963). Verfassungsauftrag und Verpflichtung des Gesetzgebers, Die öffentliche Verwaltung. Hf. 2, pp. 41 y ss., C.H. Beck, München.

Kloepfer, M. (1984). Der Vorbehalt des gesetzes im Wandel, Juristen Zeitung, Hf. 15/16, Frankfurt.

Knitiel, W. (1967) Die verfassungsgerichtliche Normenkontrolle als Ursache von Gesetzlücken. Zu den Auswirkung der Verfassunswidrigkeit-dcr 1628, 1629, $I B G B$, Juristenzeitung, Hfr. 3, Berlin.

Kohler, H.V. (1955). Kann der Gesetzgeber durch Schweigen die Verfassungswir klichkeit ändern?, Neue Juristiche Wochenschrift, Hf. 30, Frankfurt.

Korinek, K. (1986). Die Verfassungsgerichtsbarkeit in Osterreich. En Verfassungs gerichtsbarkeit in Westeuropa, Bd. I, Starck/Weber (Hrsg.), Baden-Baden: Nomos.

Larenz, K. (1960). Methodenlehere der Rechtswissenschaft, Springer, Berlin, Göttingen, Heidelberg.

- (1965). Richterliche Rechtsfortbildung als metodische Problem, Neue Juristische Wochenschrtft, HL 1/2,. pp. 1 y ss.

Lechner, (1955). Zur Zulássigkeit der Verfassungsbeschwerdegcgen Unterlassungen des Gesetzgebers. Neue Juristische Wochenschrtift, Hf. 49, pp. 1817 y ss. 
- (1965). Das Bundesverfassungsgericht und dic Verfassungsdirektiven. Zu den 'nicht erfüllten Gesetzgebungsauftragen, Archivfzir Offentliches Recht, Hf. 3. pp. 341 y ss.

Leibholz, G. (1973) Verfassungsstaat - Verfassungsrecht. Kohlhammer, Stuttgart/ Berlin/Kóhn/Mainz.

- (1974). Strukturprobleme der modernen Demokratie, Scriptor, Kronberg/ Ts. (reimp. de la 3. ed. 1967). (Hay traducción parcial al español, Problemas fundamentales de la Democracia moderna, Instituto de Estudios Políticos, Madrid, 1971, trad. de Fuente E.).

Lerche, P. (1965). Das Bundesverfassungsgericht und die Verfassungsdirektiven $\mathrm{Zu}$ den nicht erfullten Gesetzgebungsaufträgen. Berlín, Alemania: Archiv für öffentliches Recht, Hf. 3. (pp. 341 y ss. - pp. 371 y 372).

López, L., (1981). El tribunal Constitucional y el principio "stare decisis". En: El Tribunal Constitucional, (pp. 1433 y ss.), Vol. II, Madrid: Instituto de Estudios Fiscales.

Laband, P. (1911). Das Staatsrechts des Deutschen Reiches. Tübingen.

Langer, S. (1987). Staatshaftung fir Waldschäden wegen Verletzung grundrechtlicher Schutzplichten?, Neue Verwaltung Zeitschrift, Hf. 3, Frankfurt.

Lasagabaster, I. (1991). El principio de supletoriedad. Comentario a Ia STC 147/91, de 4 de julio, Revista Vasca de Administración Pública. No. 31, pp. 261 y ss.

_. El ordenamiento jurídico comunitario y el principio de supletoriedad, Revista Vasca de Administración Pública, No. 36, 1993, pp. 175 y ss.

Lucasa, P. (1979). El examen de la constitucionalidad de las leyes y la soberanía parlamentaria. Revista de Estudios Politicos, No. 7, Madrid.

Lucas Verdu, P. (1981). Política y justicia constitucionales. Consideraciones sobre la naturaleza y funciones del Tribunal Constitucional. En El Tribunal Constitucional, Vol. 11. Madrid: Instituto de Estudios Fiscales.

Meder, G., (1971). Verfassungsbeschwerde gegen gesetzgeberisches Unterlassen. Deutsches Verwaltungsblatt. (pp. 848 y ss).

Mortati, C., (1964). Atti con forza di legge e sindicato di costituzionalita. Milano: Giuffré.

---. (1972). Appunti par uno studio sui rimedi giurisdizionali contro comportamenti omissivi dellegislatore. En Problemi di Diritto Pubblico nell'aittuale esperienze costituzionale repubblicana. (pp. 923 y ss.). Raccolta di ScrittiA, T. III, Milano: Giuffré.

—. (1976). Instituzioni di Diritto Pubblíco, Vol. II, (9. edic.). Padova: CEDAM,. Manzella, A. (1991). Il parlamento. Bologna: Il Mulino.

Maunz, Schmidt-Bleibtreu, Klein \& Ulsamer. (1964-1994). Bundesverfassungsgerichtsgesetz, München: C. H. Beck. 
Mcilwain, Ch. H. (1991). Constitucionalismo antiguo y moderno. Centro de Estudios Constitucionales (trad. Solozabal). Madrid.

Miranda, J. (1991). Manual de Direito Constitucional, Coimbra: Coimbra Editora,

Moench, C. (1977) Verfassungswidriges Gesetz und Normkontrolle. Die Problematik der verfassungsrichtlichen Sanktion, dargestellt anhand der Rechtsprechung des Bundesverfassungsgerichtes, Nomos, Baden-Baden.

Montero \& Garcia. (1984). El control parlamentario, Madrid: Tecnos.

Montoro, M. J. (1986). La inactividad administrativa en el proceso de ejecucion de las leyes. Control jurisdiccional versus fracaso legislativo, Revista de Administración Pública, No. 110, Barcelona.

Murphy, Fleming \& Hauis. (1986). American Constitutional Interpretation, Mineola: Foundation Press,

Nieto, A. (1983). Peculiaridades juridicas de la norma constitucional. Revista de Administración Pública, No. 100/102, pp. 371 y ss.

_. La inactividad material de la Administración: veinticinco años después. Documentacion Administrativan No. 208, 1986, pp. 11 y ss.

Novak, Rotunda \& Young. (1986). Constitutional Law, West Publishing Co., St. Paul. Otto \& Pardo, I. (1977). Nación, Enciclopedia Jurídica Seix. Barcelona: Seix.

—. (1980). Lecciones de Derecho Constitucional. Oviedo: Guiastur.

—. (1981). La posición del Tribunal Constitucional a partir de la doctrina de la interpretación constitucional. En El Tribunal Constitucional, vol. 111, Madrid: Instituto de Estudios Fiscales, pp. 1935 y ss.

- (1985). La Constitución abierta, Revista de Occidente, $\mathrm{N}^{\circ} 54$. pp. 45 y ss.

—. (1989). Estudios sobre el Poder Judicial, Ministerio de Justicia, Madrid.

—. (1993). Derecho Constitucional. Sistema de fuentes, (3. reimp). Barcelona: Ariel,

Obermayer, K. (1965). Verfassungsrechtliche Aspekte der verwaltungsrechtlichen Normenkontrolle. Deutsches Verwaltungsblatt. Hf. 16. Berlin.

Perez Royo, J., (1987). La reforma de la constitución. Madrid: Publicaciones del Congreso de los Diputados.

- (1988). Tribunal Constitucional y División de Poderes. Madrid: Tecnos.

Papier, H.J. (1985). Der Vorbehalt des Gesetzes und seine Grenzen. En Die öffentliche Verwaltung zwischen Gesetzgebung und richterliche Kontrolle, Götz/ Starck (Hrsg.), C.H. Beck, München.

Perelman, Ch. (1979). La lógica juridica y la nueva retórica, (trad. Diez-Picazo). Madrid: Civitas. 
Perez, P. (1985). Tribunal Constitucional y Poder Judicial, Madrid: Centro de Estudios Constitucionales, 1985.

- (1994). La naturaleza del recurso de amparo y su configuración procesal, Revista Vasca de Administracion Publica, No. 39, pp. 89 y ss.

Preup, U. K. (1994). Revolution, Forstschritt und Verfassung. Fischer, Berlin.

Punset, R. (1993). Rehabilitación de la cláusula de supletoriedad del derecho estatal (STC 79/1992). Anuario de Derecho Constitucional y Parlamentario, No. 5, Barcelona.

- (1995). Normas impugnables y motivos impugnatorios en los procesos de control de consutucionalidad de las leyes, Revista Española de Derecho Constitucional, No. 43, pp. 209 y ss.

- (1995). Las sentencias declaratorias de la inconstitucionalidad de las leyes: consideraciones sobre la posible reforma de los articulos 39,1 y 40.1 de la LOTC. Anuario de Derecho Constitucional y Parlamemario, No 7, pp. 33 y ss.

_- (1995). Tribunal Constitucional y Órganos judiciales en la tutela de la supremacía de la Constitución. Una perspectiva general, Revista Jurídica de Asturias, No. 19, pp. 21 y ss.

—. Doctrina constitucional y órganos judiciales, Revista Española de Derecho Constitucional, No. 46, 1996, pp. 285 y ss.

Requejo, J. L., (1989). Jurisdicción e independencia judicial. Madrid: Centro de Estudios Constitucionales,

—. (1993). Constitución y remisión normativa. Perspectivas estática y dinámica en la identificación de las normas constitucionales, Revista Española de Derecho Constitucional, $\mathrm{N}^{\circ}$ 39. pp. 115 y ss.

- (1993). Igualdad en la ley y ante la ley: el criterio de la diferencia. Revista Jurídica de Asturias, $\mathrm{N}^{\circ} 17$. pp. 39 y ss.

Rodríguez, Arozamena \& Jimenez. (1995). Consideraciones sobre el control de constitucionalidad de la ley en el derecho español. En La Jurisdicción Constitucional de España. La Ley Orgánica del Tribunal Constitucional: 1974-1994. Tribunal Constitucional, Madrid, España: Centro de Estudios Constitucionales.

Rousseau, J.J. (1983). El Contrato Social. Madrid: Ed. Sarpe.

Rubio F., (1995). Derechos fundamentales y principios constitucionales (Doctrina jurisprudencial). Barcelona: Ariel.

Ramsauer, U. (1986). Die Rolle der Grundrechte im System der subjetiven öffentlichen Rechte. Archiv des öffentlichen Rechts, Bd. 111, Hf 4, Frankfurt.

Rodriguez, Arozamena, Jimenez \& otros. (1995). La Jurisdicción constitucional en España. La Ley Organica del Tribunal Constitucional 1979-1994, Madrid: Centro de Estudios Constitucionales, 
Rupp, W. (1970). Darf das Bundesverfassungsgericht an den Gesetzgeber Appellieren? En Festschrift für Gerbhard Müller, J. C. B. Mohr, Tübingen.

Schapiro, R.A., (1989). The Legislative Injunction: A Remedy for Unconstitutional Legislative Inaction, The Yale Law Journal, Vol. 99, No. 1, pp. 231 y ss.

Schenke, W.R., (1991). Rechtsschutz gegen das Unterlassen von Rechtsnormen. Verwaltungs Archiv, Hf. 3. pp. 308 y ss.

Schneider, H.P., (1991). Democracia y Constitución. Madrid: Centro de Estudios Constitucionales,

Schneider, R. (1964). Rechtsschutz gegen verfassungswidrieges Unterlassen des Gesetzgebers. Archiv de öffentlischesn Recht, Bd. 89, pp. 24 y ss.

Seufert, L., (1969). Die nicht erfüllten Gesetzgebungsgebote des Grundgesetzes und ihreverfassungsgeríchtliche Durchsetzung. En Beitrag zum Problem gesetzgeberischen Unterlassens, Würzburg.

Silvestri, G., (1981). La sentenze normative de/la Corte Costituzionale. Giurisprudenza Costituzionale, pp. 1684 y ss.

Stahler, K., (1966). Verfassungsrechtliche Nachprüfung gesetzgeberischen Unterlassens. München.

Sustein, C., (1993). The Partial Constitution. Cambridge/Massachusett: Harvard Univ. Press.

Santamaria, J. A. (1972). La teoría de la responsabilidad del Estado legislador, Revista de Administración Publica, No. 68, 1972, Barcelona.

Santaolalla, F. (1994). Televisión por cable y control de omisiones del legislador (STC 31/1994, de 31 de enero), Revista Española de Derecho Constitucional, No. 41, Madrid.

Santos, J. M. (1995). Doctrina y jurisprudencia del Tribunal Constitucional, su eficacia respecto de los tribunales ordinarios, Granada: Comares.

Sartori, G. (1962). Constitucionalism: a Preliminary Discussion, The American Political Science Review.

Scheuner, U. (1974). Staatszielbestimmungen, en Festschrift für Forsthoff zum 70, Geburtstag, Schnur (Hrsg.), München: C. H. Beck,

Schilling, T. (1994). Rang und Geltung von Normen in gestufien Reclusordnungen, Berlin Verlag/Nomos, Berlin/Baden-Baden.

Schlaich, K. (1991). Das Bundesverffassungsgericht. Stellung, Verfahren, Entscheidungen, München: C. H. Beck.

Schneider, H. P. (1991). Democracia y Constitucion, Madrid: Centro de Estudios Constitucionales. 
Snowiss, S. (1990). Judicial Review and the Law of the Constitution, Yale University Press, New Haven, CT.

Soares Manso, J. A. (1981). La fiscalización de la constitucionalidad de las leyes. En El Tribunal Constitutional, Vol. III, Madrid: Instituto de Estudios Fiscales, Stein, E. (1964). Die verfassungsrechtlichen Grenzen der Rechtsfortbildung durch Rechtsprechung, Neue Juristische Wochenschrift, Hf. 38/39, Berlin.

Stone, Seidman, Sunstein \& Tushnet. (1991). Constitutional Law, Little Brown and Company, Boston, Toronto, London, (2a. edic.).

Sunstein, C. (1993) The Partial Constitution, Harvard University Press, Cambridge/ Massachusett.

Tomas y Valiente, F. (1993). Escritos sobre y desde el Tribunal Constitucional, Madrid: Centro de Estudios Constitucionales,

Tornos, J. (1993). Legislación básica y doctrina del Tribunal Constitucional, Revista Vasca de Administracion Publica, No. 36, Barcelona.

Tribe, L. H. (1988). American Constitutional Law, (2a. edic.). New York: Foundation Press, Mineola.

Umback, D. C. (1984). Das Wesentliche an der Wesentlichkeitstheorie. En Fcstschrift für Hans Joachim Faller, Zeidler/Maunz/Roellecke, C. H. Beck. München.

Wahl, R., (1981) Dar Vorrang der Verfassung. Der Staat, Bd. 20, Hf. 4. pp. 485 y ss. Wessel, (1952). Die Rechtsprechung des Bundesverfassungsgerichts zur Verfasiungsbeschwerde. Deutsches Verwaltungsblatt, Hf. 6. pp. 161 y ss.

Varela, J. (1983). La Teoría del Estado en los orígenes del Constitucionalismo Hispánico (Las Cortes de Cadiz), Madrid: Centro de Estudios Constitucional.

Vega, P. de. (1979). Jurisdicción Constitucional y Crisis de la Constitución, Revista de Estudios Politicos, No. 7, Madrid.

Verdross, A. (1968). Zum Problem der Rechtsunterworfenheit des Gesetzgebers, En Die Wiener Rechtstheoretische Schule, Klecatsky/Marci/Schambeck, Europa Verlag/Pustet, Frankfurt, Zurich. Salzburg, München.

Villa, J. L. (1975). La interpretación y los apotegmas juridico-logicos, Madrid: Tecnos.

Westbomke, K. (1976). Der Anspruch auf Erlass von Rechtsordnunggen und Satzung, Duncker \& Humblot, Berlin.

Wright, G. H. v. (1979). Norma y acción, Una investigación lógica, Madrid: Tecnos, (reimp. $1^{\mathrm{a}}$. ed. trad. Garcia Ferrero).

Younes, D. (1994). Derecho Constitucional Colombiano. Bogotá, Colombia: Ediciones Jurídicas Gustavo Ibáñez. 


\section{LA JURISDICCIÓN DE LO CONTENCIOSO \\ ADMINISTRATIVO EN COLOMBIA: UNA EXPRESIÓN \\ DE EXISTENCIA DEL CONSEJO DE ESTADO*}

Ciro Nolberto Güechá Medina*

\section{INTRODUCCIÓN}

Siempre que se hable de la Jurisdicción de lo Contencioso Administrativo, se debe referir también al Consejo de Estado, pues este órgano refleja su origen, su evolución y en especial su existencia, como jurisdicción especial de la Administración. Aunque el Consejo de Estado no cumplió siempre funciones jurisdiccionales, sino que en algunos casos se ha mostrado como órgano consultivo o asesor del ejecutivo, sí ha servido de punto de partida para la organización de lo contencioso, porque así fuera desarrollando funciones no jurisdiccionales, intervino en su formación a través de conceptos y recomendaciones, que luego fueron tomadas como parte de esta jurisdicción.

El presente escrito pretende realizar un análisis detallado del máximo órgano de la jurisdicción contenciosa, partiendo de sus antecedentes, creación y consagración actual, tanto constitucional como legal. Las decisiones del Consejo de Estado, han determinado la identidad de la jurisdicción de lo contencioso administrativo, ya que el derecho procesal en muchos casos es de carácter jurisprudencial, es decir, que se establece a través de las decisiones de este órgano jurisdiccional.

* El presente capítulo de libro es producto del proyecto de investigación "Derecho Administrativo" el cual se constituye en uno de los proyectos de investigación institucionales de la Universidad Santo Tomas (Sede Bogotá).

** Doctor en Derecho - Universidad Externado de Colombia. Doctor en Derecho Administrativo - Universidad Alfonso X El Sabio. Decano de la Facultad de Derecho de la Universidad Santo Tomas (Sede Bogotá). Docente e Investigador del Centro de Investigaciones de la Facultad de Derecho de la Universidad Santo Tomas (Sede Bogotá). Correo Electrónico: ciroguecha@usantotomas.edu.co 
Debido a la importancia que tiene el Consejo de Estado para la Jurisdicción de lo Contencioso Administrativo, mostraremos no sólo su origen sino su desarrollo e influencia sobre la jurisdicción de lo contencioso administrativo, a través de cuatro secciones, así: creación y desarrollo del Consejo de Estado colombiano, impulso del Consejo de Estado, perfeccionamiento del Consejo de Estado y por último, reafirmación del Consejo de Estado.

\section{SECCIÓN PrImera \\ CREACIÓN Y DESARROLLO DEL CONSEJO DE ESTADO COLOMBIANO}

El Consejo de Estado en Colombia a pesar de tener un origen directo con la expedición del decreto del Libertador Simón Bolívar en 1817, remonta sus orígenes al Consejo de Estado francés de Napoleón Bonaparte de 1799; el cual, a su turno tiene antecedentes remotos en instituciones romanas como el consilium principis creado por Octaviano Augusto, que era un consejo de asesores del Príncipe o Emperador que le recomendaba las decisiones que por su investidura de autoridad unipersonal le correspondía tomar; posteriormente, el Emperador Diocleciano lo transformó en consistorium principis aumentando su importancia de órgano consultivo del soberano ${ }^{16}$. Por su parte, el Consejo del Rey, constituye antecedente ya más próximo del Consejo de Estado en Francia, el cual aparece a finales del siglo XIII y comienzos del XIV como cuerpo asesor de los Reyes de la época, el cual fue evolucionando y a la par de otras instituciones como el Consejo de Jueces creado por Felipe E1 Hermoso, la Cámara de Cuentas de Felipe V le fueron dando aportes significativos a la posterior formación del Consejo de Estado ${ }^{17}$. Esto sin olvidar que Enrique III organizó una especie de jurisdicción administrativa, cuando los particulares podían acudir ante el rey para formular sus demandas a través de los requetes y que Luis XIV conformó varias comisiones de asesores especializados, que dieron origen

16 Penagos, Gustavo. Derecho Administrativo Parte General, segunda edición actualizada, Bogotá: Ediciones Librería El Profesional, p. 70.

17 Ibíd., p. 71. Los Reyes Merovingios y Carolingios son famosos por sus consejos de asesores, que les ayudaban a tomar decisiones políticas. 
a un consejo privado especializado de finanzas y dirección, que era el que recomendaba las decisiones contencioso administrativas ${ }^{18}$.

Pero es con la Revolución Francesa, donde el Consejo de Estado tiene su fuente inmediata, ya que el Consejo del Rey es despojado de sus facultades judiciales, las cuales fueron radicadas en el Tribunal de Casación, lo que llevó a que mediante la Ley 27 de abril de 1791 se le suprimiera definitivamente y en su lugar se creara una especie de Consejo de Estado y un Consejo de Ministros, al cual se le dieron atribuciones respecto de asuntos de asesoría del ejecutivo; consejo que posteriormente llevaría a la creación del Consejo de Estado propiamente dicho ${ }^{19}$; lo cual le daría a la jurisdicción contencioso administrativa un gran avance frente a la jurisdicción ordinaria, ya que esta institución ganaría prestigio, respeto y admiración general, pues ha realizado una importante función administrativa al lado de la jurisdiccional ${ }^{20}$.

1. EL CONSEJO DE ESTADO EN COLOMBIA: COPIA DEL CONSEJO DE ESTADO FRANCÉS?

Napoleón Bonaparte, en el artículo 52 de la Constitución francesa del año VIII (1799) creó el Consejo de Estado, el cual tenía similitud con el Consejo del Rey, en principio poseía atribuciones en el ámbito legislativo y en el administrativo; en el legislativo, le correspondía preparar los proyectos de ley y en el administrativo, servía como asesor de la Administración. El profesor VEDEL, al referirse a las atribuciones del Consejo de Estado dice:

«El Consejo de Estado tenía una doble misión: en el orden legislativo, redactaba al primer cónsul los proyectos de ley; en el orden de la administración, actuaba como asesor del ejecutivo. A este título, era frecuente que propusiese al primer cónsul la solución de los litigios administrativos, $\mathrm{y}$, desde el 5 nivoso del año VIII, un reglamento establece que el Consejo de Estado estará encargado de los asuntos contenciosos"21.

\footnotetext{
18 Galindo Vácha, Juan Carlos. Lecciones de Derecho Procesal Administrativo, Bogotá: Pontificia Universidad Javeriana, 2003, p. 179.

19 Penagos Gustavo. En: Revista Universitas Pontificia Universidad Javeriana $\mathrm{N}^{\circ}$. 50, Bogotá, junio 1976, pp. 17 y 18.

20 R.C.K. Ensor. Jueces y tribunales en Francia y Alemania, Traducción de Emilio Gómez Orbaneja, Madrid - España, Ed. Revista de Derecho Privado, p. 63.

21 Vedel, Georges. Derecho Administrativo, Madrid: Editorial Aguilar, 1980, p. 60.
} 
El Consejo de Estado nace bajo la existencia de la justicia retenida, por lo que sus actuaciones se limitan a asesorar al ejecutivo en la solución de los conflictos en que era parte la Administración, ya que la decisión en última instancia radicaba en quien ejercía el poder político, que no era otro que el primer cónsul, es decir, Napoleón Bonaparte. Desde el punto de vista de la jurisdicción contencioso administrativa, la aparición del Consejo de Estado es trascendental, así en principio hubiese actuado como simple asesor del ejecutivo, pues en un comienzo se le atribuyó lo relacionado con los asuntos contenciosos y para desarrollar esa atribución, implementó un procedimiento específico muy similar al procedimiento jurisdiccional, el cual determinaba una claridad diáfana en los asuntos respecto de los cuales intervenía y las recomendaciones que daba eran por lo general adoptadas por el ejecutivo. Se dice que durante el período durante el cual imperó esta justicia retenida, sólo en un par de oportunidades el ejecutivo se apartó de sus recomendaciones ${ }^{22}$.

Aun en vigencia del sistema de la justicia retenida, el Consejo de Estado francés siguió avanzando hacia una conformación específica de la jurisdicción contencioso administrativa., tal es así, que en el año de 1806 se creó dentro de su seno una comisión de lo contencioso, la cual posteriormente se denominaría Sección de lo Contencioso. Posteriormente, el 3 de marzo de 1849 se dictó la ley que contemplaba que el Consejo de Estado no estaba en la obligación de consultar sus decisiones, lo cual desembocó en el famoso Fallo Blanco de 1873 del Tribunal de Conflictos, que terminó por darle total independencia a la jurisdicción contenciosa administrativa.

Entonces, la institución del Consejo de Estado es claramente una creación del derecho francés, institución que fue tomada por el Libertador Simón Bolívar para ser adoptada en nuestro medio. Es de anotar, que Bolívar era conocedor del desarrollo político y jurídico de la Europa de la época, por su estadía en el viejo continente; para nadie es desconocido que sus ideales revolucionarios se inspiraron en gran medida en las ideas revolucionarias francesas y en las enseñanzas de sus maestros Simón RoDRíGuez y Andrés BELLO.

Determinado el origen específico del Consejo de Estado como institución francesa, miremos como fue su creación en nuestro país:

El decreto del Libertador Simón Bolívar por medio del cual se creó el Consejo de Estado dice:

22 Ibid, pp. 60-61. 


\section{"Simón BOLÍVAR.}

Jefe Supremo de la República de Venezuela y Capitán General de sus ejércitos y de los de la Nueva Granada, etc.

Considerando que es imposible restablecer por ahora un buen Gobierno representativo y una Constitución eminentemente liberal, a cuyo objeto se dirigen todos mis esfuerzos y los votos más ardientes de mi corazón, mientras no se halle libre y tranquila la mayor parte del territorio de la República, especialmente la capital, y deseando que las provincias importantes, las leyes, reglamentos e instrucciones saludables que deben entretanto publicarse para la administración y organización de las provincias ya libres o que se liberten, sean propuestas, discutidas y acordadas en una asamblea que por su número y por la dignidad de los que la compongan merezca la confianza pública, he venido en decretar y decreto lo siguiente:

Artículo $1^{\circ}$. Tendrá el Jefe Supremo de la República un Consejo Provisional de Estado que residirá por ahora en la capital de la provincia de Guayana, y será compuesto del Almirante del Estado Mayor General, del Intendente General, del Comisario General del Ejército, del Presidente y Ministros de la Alta Corte de Justicia, del Presidente y Ministro del Tribunal de Secuestros, de los Secretarios del Despacho y de los empleados siguientes de esta provincia, mientras resida en su capital, a saber: El Gobernador Comandante General, los Generales y Coroneles que estén en actual servicio en esta ciudad, el Intendente, los Ministros, Contador y Tesorero y el Gobernador Político.

Artículo $2^{\circ}$. El Consejo se dividirá en tres secciones: 1a. Estado y Hacienda; 2a. Marina y Guerra; 3a. Interior y Justicia.

Artículo $3^{\circ}$. El Gobierno nombrará los miembros del Consejo de Estado que deben componer cada sección, y elegirá entre ellos los que deban presidirlas.

Artículo $4^{\circ}$. El Consejo de Estado no puede ser convocado ni presidido sino por el Jefe Supremo, pero en su ausencia será presidido por el Consejero a quien haya delegado esta función. Las secciones serán convocadas por sus presidentes respectivos, según lo exijan los asuntos en que se ocupen.

Artículo $5^{\circ}$. Todo individuo de una sección puede proponer en ella cuantos planes, reglamentos, providencias, etc., le parezcan convenientes al bien público en el ramo de sus atribuciones, pero solo el presidente de la sección puede hacerlo en Consejo de Estado, siempre que el proyecto haya sido aprobado por la sección. 
Artículo $6^{\circ}$. El Jefe Supremo convoca según le parece, una o dos secciones, o el Consejo General de Estado; pero ni aquellas ni éste podrán tener en ningún caso más que voto consultivo.

Artículo $7^{\circ}$. Las comunicaciones que ofrezcan entre dos secciones se harán por medio de uno o dos individuos comisionados para la discusión; pero las secciones mismas no podrán reunirse entre sí sino por disposición del Jefe Supremo.

Artículo $8^{\circ}$. Sin embargo de que las secciones indican bastantemente el objeto de sus atribuciones, se especifican; la primera, las relaciones internacionales, todos los negocios de Estado alta policía, arreglo de contribuciones directas o indirectas, administración de rentas, etc., la 2 a. todo lo concerniente a la organización de las fuerzas de tierra y mar y a la administración militar, armas, víveres, vestuarios, pertrechos y municiones, etc. La 3a. la administración civil y de justicia, la policía municipal, todo lo relacionado al fomento interior, comercio, agricultura, industria, instrucción pública, establecimientos de beneficencia, caminos, puentes y calzadas, etc.

Artículo $9^{\circ}$. El Consejo de Estado tendrá un secretario que debe ser nombrado por el Gobierno Supremo.

Artículo 10. Si convocado el Consejo de Estado, o una de sus secciones, se conformare el Jefe Supremo con su dictamen, el Decreto que recaiga sobre él, lo expresará por esta fórmula: oído el Consejo de Estado, u oída la sección $\mathrm{N}$ o las secciones NN del Consejo de Estado.

Artículo 11. Para los asuntos que el Jefe Supremo quiera consultar en particular, habrá un Consejo privado compuesto del Almirante, de los Gobernadores Militar y Político, de los Presidentes de las Secciones, y de los Secretarios del Despacho.

Dado, firmado de mi mano, sellado con sello provisional de la República, y refrendado por el Secretario del despacho, en el Cuartel General de Angostura a 30 de octubre de 1817.

Simón BOLÍVAR"23

El decreto expedido por el Libertador, contiene en su motivación los fundamentos que originaron la creación de la institución, los cuales podemos sintetizar de la siguiente manera:

23 Bolívar, S. Decreto dictado por el Libertador el día 30 de octubre de 1817 en Angostura, hoy República Bolivariana de Venezuela, cuando hacía parte la Gran Colombia; que como hecho curioso, tuvo su primera sede en la capital de la provincia de Guayana. 
Se estaba ante la imposibilidad de establecer un gobierno representativo. Recordemos que en esos momentos venía llevando a cabo la campaña libertadora y era imposible establecer un sistema de gobierno que constituyera representación popular.

Además, no era posible establecer una Constitución de carácter liberal. Al no existir un sistema representativo, era imposible establecer una Constitución de corte liberal, es decir, con garantía de derechos y libertades.

Era primordial la necesidad de que las providencias, leyes y reglamentos tuvieran confianza pública. Por no existir un gobierno que estaba en formación, era necesario poseer una institución que le prestara asistencia en las decisiones que tomaba, para que las mismas tuvieran credibilidad dentro de la población; más, si pretendía afianzarse como poder imperante.

En cuanto a su conformación, el Consejo de Estado estaba integrado por secciones, que contenían los sectores más representativos de poder en ese momento, como eran Estado y Hacienda, Marina y Guerra, Interior y Justicia.

Por lo demás, el Consejo de Estado en la concepción del decreto del Libertador, nació como un órgano asesor del ejecutivo; así se colige de lo contemplado en el artículo 10 cuando expresa, que si el jefe supremo está conforme con el dictamen, es decir, con el concepto dado por el Consejo o por una sección o secciones, así lo consignará en el decreto respectivo y para tal fin da una fórmula específica: oído el Consejo de Estado, oída la sección $\mathrm{N}$, oídas las secciones $\mathrm{NN}$, se toma una u otra decisión.

Como se puede ver, el Consejo de Estado en nuestro país llega a la vida jurídica no como un órgano jurisdiccional independiente, como lo conocemos actualmente, sino que lo hace como un órgano asesor del ejecutivo, como un auxiliar del poder ejecutivo que daba dictamen para la sanción de las leyes, preparaba los proyectos de ley y absolvía consultas en asuntos generales de la Administración ${ }^{24}$; que posteriormente sufrió transformaciones en uno u otro sentido, hasta adquirir el status de máximo órgano de la jurisdicción contencioso administrativa. La idea de crear un Consejo de Estado como el que venimos estudiando, no fue original del General Simón Bolívar, sino que ésta como otras instituciones, fueron traídas del derecho francés, país desde donde se nos ha exportado muchos de nuestros órganos jurisdiccionales; creación que obedeció en palabras de Galindo Vácha, por el gran conocimiento del Libertador Simón Bolívar de

24 Gómez, P. El Consejo de Estado, Bogotá: Imprenta Nacional, 1934. 
Napoleón Bonaparte, de donde se desprende que esta institución pretendía emular el Consejo de Estado francés ${ }^{25}$.

\section{LA FUENTE CONSTITUCIONAL DEL CONSEJO DE ESTADO}

Para estudiar un organismo como el Consejo de Estado, es necesario conocer cuál ha sido su naturaleza y consagración en las primeras constituciones que se han dado en nuestro territorio; haciendo claridad, que haremos referencia únicamente a las constituciones del orden nacional, ya que en el sistema federalista que en alguna época imperó, cada Estado se dio su propia Constitución.

No se nos olvide que aparte del decreto de creación expedido por el Libertador Simón Bolívar y hasta el año de 1914, el Consejo de Estado fue concebido en principio como una institución de carácter constitucional, es decir, que fue contemplado en las constituciones respectivas.

Para hacer mayor claridad en el estudio, dividiremos el análisis en varios aspectos así: En primer lugar lo analizaremos como órgano asesor del ejecutivo, en segundo lugar determinaremos el período de inexistencia y sustitución por el denominado Consejo de Gobierno o Consejo de Ministros, en último lugar miraremos lo que hemos denominado como su renacimiento $\mathrm{y}$ el retroceso que existió a comienzos del siglo XX.

2.1. El CONSEJO DE ESTADO UN ÓRGANO ASESOR DEL PODER EJECUTIVO

La historia política del país, muestra que uno de los acontecimientos más controvertidos se dio con la dictadura del Libertador del año 1828; esta se originó de una u otra forma en la Convención de Ocaña, que fue instalada el 9 de abril del mismo año, en la que desde un principio existió controversia entre quienes defendían un sistema de carácter federal, que constituían mayoría y reflejaban el pensamiento santanderista y otros, que siendo minoría propugnaban por el sistema centralista y que a su vez reflejaban las ideas de BOLÍvAR. Los santanderistas o anti bolivarianos, partidarios de disminuir la concentración de poderes por temor a la ya previsible dictadura del General BoLÍVAR, eran fervientes defensores de desconcentrar, de limitar el poder; por su parte los bolivarianos perseguían una rigurosa centralización,

25 Galindo, op. cit., p. 140. 
disminución de las libertades públicas y de las libertades individuales, para darle más estabilidad y fortaleza a la ya resquebrajada unión de la Gran Colombia, el sueño político del libertador. Ante la imposibilidad de ponerse de acuerdo uno y otro bando, los bolivarianos se retiraron de la convención, lo que originó la imposibilidad de tomar decisiones, ya que se requerían las dos terceras partes de los miembros; ante tal situación la convención fue disuelta ${ }^{26}$. En el hecho de la disolución de la Convención de Ocaña, los partidarios de BOLÍVAR vieron la posibilidad de darle poderes especiales, a lo que en efecto el Intendente de Cundinamarca General Pedro Alcántara Herrán inviste a Bolívar con el carácter de dictador, lo que precipita que Bolívar asumiera los máximos poderes otorgados y expida el Decreto Orgánico de la Dictadura el 27 de agosto de 1828, el cual no implicó únicamente la aparente legitimación del poder omnímodo que se le pretendía dar a Simón Bolívar, sino la muestra de unas instituciones importantes de orden administrativo como el Consejo de Estado, que vino a constituirse como un ente asesor del ejecutivo y además, en un control de los poderes excepcionales del mismo, como lo expresan Manuel Antonio Pombo y José Joaquín Guerra, cuando dicen:

"Al lado del lunar que más se destacaba en este decreto -la supresión de la vicepresidencia- y que tan mal efecto produjo entre los antibolivianos, contiene algunas disposiciones constitucionales bastante importantes, como la creación del Consejo de Estado, para templar el rigor del régimen dictatorial que se implantaba..." 27.

En esta disposición de rango constitucional, se consagró el Consejo de Estado como órgano asesor del gobierno y para tal fin cumplía las funciones de preparar los decretos y reglamentos que debía expedir el jefe de Estado, dar concepto o dictamen al gobierno en caso de declaratoria de guerra, preliminares de paz o ratificación de tratados y en los demás eventos que se le solicitara. Se estableció que el Consejo de Estado debía darse un reglamento, que contendría las reglas de proceder o actuación de dicho Consejo; es decir, que se contempló un procedimiento que se debía agotar por parte del Consejo de Estado para el cumplimiento de sus funciones. Aquí encontramos el germen de un procedimiento contencioso administrativo.

26 Palacios, M.. Colombia país fragmentado, país dividido, Bogotá, p. 261.

27 Pombo, M. A. y Guerra, J. J. Constituciones colombianas, T. III, Bogotá: Ed. Biblioteca Banco Popular, 1986, p. 172. 
Además, era obligación del jefe supremo del Estado oír el concepto del Consejo de Estado, en caso de conmutar penas capitales y conceder amnistías o indultos generales o particulares y de disminuir las penas por motivos de conveniencia pública. La norma constitucional no contempló si el concepto o dictamen del Consejo de Estado era obligatorio; es decir, si el gobierno debía tomar la decisión recomendada por el Consejo; consideramos que dado el carácter de órgano asesor, sus conceptos no eran obligatorios para el jefe del Estado, lo que sucedía era que difícilmente se apartaba del mismo por su carácter de órgano asesor del ejecutivo como ocurría en la época napoleónica.

En cuanto a su organización, el Consejo de Estado estaba integrado por: El Presidente del Consejo de Ministros, los ministros secretarios de Estado y al menos un Consejero por cada uno de los departamentos de la República. En esta disposición de rango constitucional, como es el Decreto Orgánico de la Dictadura, el Consejo de Estado apareció como un órgano perteneciente a la rama ejecutiva y aún no tenía el carácter de órgano jurisdiccional.

Por su parte en la Constitución de 1830, denominada Constitución de la República de Colombia, respecto de la que como ya se dijo nació muerta, pues la Gran Colombia donde se pretendía que rigiera, ya estaba disuelta por los acontecimientos originados en los levantamientos separatistas de Páez en Venezuela y Flores en el Ecuador, que dieron al traste con el sueño de Bolívar $^{28}$, se consagró el Consejo de Estado en la sección tercera del título VII que hacía referencia al poder ejecutivo; fue concebido como órgano asesor del poder ejecutivo y se le dio la función de auxiliar a dicho poder en las diferentes ramas de la Administración Pública.

Se le atribuyeron como funciones las siguientes:

- Preparar los proyectos de ley que el jefe de Estado debía presentar al Congreso.

- Rendir dictamen para el nombramiento de agentes diplomáticos, ministros plenipotenciarios, cónsules generales y enviados diplomáticos.

- Rendir concepto para el nombramiento de los magistrados de las cortes de apelación, los prefectos de los departamentos y los gobernadores de las provincias.

28 Palacios, op. cit., p. 267. 
- Rendir concepto para el nombramiento del Procurador General de la Nación.

- Rendir concepto o dictamen para casos de conmutar la pena capital.

- Rendir dictamen para la sanción de las leyes.

- Rendir dictamen en todos los negocios o actividades considerados graves, que correspondían a la Administración Pública y en los casos exigidos por el jefe del ejecutivo ${ }^{29}$.

Como se puede ver, este organismo se concibió como un consejo asesor del ejecutivo, en las diferentes actuaciones administrativas del jefe de Estado; es de anotar que la norma constitucional, contempló la circunstancia de no ser obligatorio para el ejecutivo el dictamen dado por el Consejo de Estado para cada caso. El Consejo de Estado estaba integrado por el Vicepresidente de la República quien lo presidía, los Ministros Secretarios del Despacho, el Procurador General de la Nación y dos consejeros escogidos indistintamente; para ser Consejero de Estado se requería ser colombiano en ejercicio de derechos y gozar de buen concepto público.

Por su parte la Constitución de 1832, que se constituyó en la primera dictada en nuestro territorio una vez disuelta la Gran Colombia, consagró el Consejo de Estado en la sección quinta del título sexto como parte del poder ejecutivo.

Al Consejo de Estado se le asignaron funciones de órgano asesor del ejecutivo, cumpliendo para tal fin las siguientes atribuciones:

- Rendir dictamen o concepto para la sanción de las leyes.

- Dar concepto en todos los casos graves o delicados de la Administración Pública.

- Preparar los proyectos de ley y de códigos que se debían presentar al Congreso.

- Presentar a la Cámara de Representantes, ternas para los nombramientos de miembros de la Corte Suprema de Justicia.

- Dar consentimiento para el nombramiento de ministros plenipotenciarios, agentes diplomáticos, cónsules generales y enviados diplomáticos.

29 “Constitución de 1830, artículo 97”. En: Restrepo, C. Constituciones Políticas Nacionales de Colombia, Bogotá: U. Externado de Colombia, 1955, p. 122. 
- Dar consentimiento para los nombramientos de los magistrados de distrito judicial.

- Dar consentimiento para conmutar la pena capital ${ }^{30}$.

Se debe hacer claridad, en el sentido que los conceptos o dictámenes del Consejo de Estado no obligaban al ejecutivo, sino que este se podía apartar de los mismos. El Consejo de Estado estaba integrado de la siguiente manera: siete consejeros nombrados por el Congreso por pluralidad de votos; los Secretarios de Estado podían asistir y tomar parte en las discusiones, pero no votaban. En esta Constitución se contemplaba que fuera el Congreso quien eligiera los Consejeros de Estado y no el ejecutivo, hecho que le daba un grado de independencia en los conceptos que rendía. Los Consejeros de Estado eran nombrados por un término de cuatro años, renovándose por mitad cada dos años.

A pesar de que los Consejeros de Estado rendían conceptos que en última instancia no obligaban al ejecutivo, eran responsables de sus dictámenes y del desempeño de sus funciones; se les asignó a los miembros de Consejo de Estado una remuneración, lo cual se hacía a través de una ley de la República, esto porque tenían dedicación exclusiva y además no podían desempeñar otro empleo.

Para ser Consejero de Estado se requería ser granadino de nacimiento y cumplir los demás requisitos que se necesitaban para ser Senador; esto es, haber cumplido treinta y cinco años, ser vecino de la provincia por la cual se hacía la elección, tener cuatro años de residencia en la República, ser dueño de bienes raíces que alcanzaban un valor libre de cuatro mil pesos o en su lugar tener una renta de quinientos pesos anuales que provinieran de bienes raíces o de ochocientos pesos que fueran el producto de un empleo o el ejercicio de una industria o profesión.

El Consejo de Estado seguía siendo un órgano asesor del ejecutivo, pero como hecho significativo a lo cual ya se hizo referencia, los consejeros no eran designados por el ejecutivo sino por el Congreso, lo que podía generar una mayor autonomía en los conceptos que rindiera.

30 “Constitución de 1832, Artículo 128”. En: Restrepo, C. Constituciones políticas nacionales de Colombia, Bogotá: U. Externado de Colombia 1955, p. 170. 


\subsection{SUPRESIÓN Y CAMBIO DEL CONSEJO DE ESTADO}

Creado el Consejo de Estado por el Libertador Simón Bolívar mediante el Decreto de 1817, su permanencia en la vida jurídica no fue constante, sino que en muchas ocasiones fue suprimido o sustituido por consejos de gobierno o de ministros. Trataremos de identificar tales situaciones dentro de las constituciones respectivas.

En la Constitución de 1821 no se consagró la figura del Consejo de Estado, este fue remplazado por un Consejo de Gobierno, el cual hacía parte del poder ejecutivo en calidad de asesor del Presidente; era obligatorio para el Presidente oír el dictamen del Consejo de Gobierno para ciertos casos específicos, como las objeciones a los proyectos de ley que el Presidente considerara inconveniente, la declaración de guerra, la celebración de tratados de paz, los nombramientos de ministros y agentes diplomáticos, el conmutar la pena capital en ciertos casos, dictar medidas especiales en caso de conmoción interior o invasión exterior y repentina, etc. Es de anotar que los conceptos o dictámenes del Consejo de Gobierno no eran obligatorios para el Presidente de la República, sin embargo, mirando las competencias y la organización del Consejo de Gobierno de 1821, nos damos cuenta que era en esencia el mismo Consejo de Estado de 1817.

En igual forma, en la Constitución de 1843 no se consagró la institución del Consejo de Estado, el cual fue sustituido por lo que se denominó Consejo de Gobierno, que se integraba por el Vicepresidente de la República y los secretarios de Estado, es decir, que se constituía en lo que conocemos por Consejo de Ministros, donde el jefe de Estado se rodea de sus colaboradores más cercanos para tomar ciertas decisiones de importancia.

El jefe del ejecutivo debía oír el dictamen del Consejo de Gobierno en forma obligatoria en ciertos casos, tales como:

- Sancionar o abstenerse de hacerlo respecto de los proyectos de ley.

- Convocar al Congreso a reuniones extraordinarias.

- Solicitar al Congreso autorización para declarar la guerra.

- Nombrar ministros plenipotenciarios, cónsules y demás agentes diplomáticos y comerciales.

- Nombrar los gobernadores de las provincias.

- Nombrar los ministros jueces de los tribunales superiores de distrito. 
- Conceder amnistías o indultos generales o particulares.

- Conmutar la pena de muerte ${ }^{31}$.

El dictamen que daba el Consejo de Gobierno no era obligatorio para el ejecutivo, sino que este podía apartarse del mismo. Como se puede ver, las competencias de este Consejo de Gobierno eran casi idénticas a las cumplidas por el Consejo de Estado, mostrando con ello que lo único que cambió fue el nombre.

Entonces, este Consejo de Gobierno reemplazó al Consejo de Estado y sus funciones eran en su mayoría idénticas a las que cumplía en la Constitución de 1832, es decir, que en el fondo lo que desapareció fue el nombre mas no la institución, siendo sus integrantes la gran diferencia y además la autonomía que podía tener; lo anterior si tenemos en cuenta que en 1832 los Consejeros eran designados por el Congreso y en esta Carta Constitucional los miembros del Consejo de Gobierno eran los propios secretarios de Estado y el Vicepresidente, es decir, quienes hacían gobierno con el jefe de Estado.

Por su parte, la Constitución de 1858 no contempló el Consejo de Estado como parte de la organización administrativa de la República; el artículo 36 de la Carta hablaba de un Consejo de Gobierno que en apariencia venía a suplir al Consejo de Estado como órgano asesor del ejecutivo.

El artículo 36 a la letra dice: "El Vicepresidente de la República, los Secretarios de Estado y el Procurador General de la Nación forman el Consejo de Gobierno, que presidirá el Vicepresidente en los casos que deba consultarlo el Presidente"32.

En esta disposición constitucional no se atribuyeron funciones específicas al Consejo de Gobierno, sino que simplemente se dio la posibilidad al Presidente de consultarlo en los casos que lo requiriera; solamente en el artículo 34 en su numeral décimo, hizo obligatorio para el Presidente consultar al Consejo de Gobierno y al Procurador para casos de convocar al cuerpo legislativo en ocasiones extraordinarias.

Realmente, aunque se puede decir que este Consejo de Gobierno, pudo tener alguna similitud con el Consejo de Estado como órgano asesor del ejecutivo, en realidad constituyó el típico Consejo de Ministros conocido por todos.

\footnotetext{
31 "Constitución de 1843, artículo 117”. En: Restrepo, C. Constituciones políticas nacionales de Colombia, Bogotá: U. Externado de Colombia 1955, p. 212.

32 Pombo, op. cit., p. 36.
} 
La Constitución de 1858, constituyó una expresión del sistema federalista que vivió nuestro país como régimen político a lo largo de la historia; esta Carta Constitucional no consagró la figura del Consejo de Estado, como tampoco lo hizo del Consejo de Gobierno, institución a la cual se le ha encontrado alguna similitud con el Consejo de Estado como órgano asesor del ejecutivo.

Del mismo modo la Constitución de 1863, no consagró el Consejo de Estado como institución administrativa del Estado federal y mucho menos como institución jurisdiccional, pues esta Constitución al igual que la de 1858 , es de corte federalista, por lo que los principios políticos de una y otra son similares. La Constitución previó la existencia de unos secretarios del despacho, para efectos de evacuar los negocios de competencia del poder ejecutivo, los cuales en cierto sentido podían servir de órgano asesor del Presidente de la Unión.

\subsection{El RESURGIR DEL CONSEJO DE ESTADO}

La Constitución de 1886 que implantó nuevamente en nuestro territorio una forma de Estado unitario y centralista, como reacción a la no muy bien recordada época federalista que imperó bajo las Constituciones de 1858 y 1863, que con fundamento en una soberanía seccional o fraccionada, lo único que generó fue desorganización y un deseo creciente de individualismo o regionalismo y por tal razón, los continuos levantamientos de generales o líderes locales que sólo llevaron al caos a nuestro país, contempla la institución del Consejo de Estado con una triple naturaleza: por una parte, se le dio la calidad de cuerpo consultivo del ejecutivo, por otra, de ente colegislador y por una tercera, la de órgano jurisdiccional, esta triple connotación se da por primera vez a lo largo de la historia jurídico política de nuestro país; Constitución que se constituyó en la más importante para el desarrollo de la jurisdicción de lo contencioso administrativa, pues en palabras de Libardo Rodríguez, previó por primera vez en nuestro país al Consejo de Estado, no sólo como órgano consultivo y asesor del gobierno, sino como máximo juez de la administración ${ }^{33}$.

33 Rodríguez, L. Origen y evolución de la jurisdicción administrativa en Colombia, Memorias del coloquio conmemorativo del bicentenario del Consejo de Estado Francés, Bogotá: Ed. Temis, 1999, p. 45. 
En lo referente a su composición, el Consejo de Estado estaba integrado por siete miembros, así: por el Vicepresidente de la República, quien lo presidía y seis vocales, a quienes se les daba la denominación de consejeros; los consejeros tenían suplentes, pero la Constitución dejó a la ley la reglamentación de todo lo relativo a los suplentes, es decir, su número, forma de designación, servicio y responsabilidad. Los Consejeros de Estado eran designados por el término de cuatro años, siendo su designación incompatible con cualquier otra designación; los consejeros se renovaban por mitad cada dos años. El Consejo de Estado para el cumplimiento de sus funciones se dividía en secciones, las que en su número eran establecidas por ley o a través del reglamento del propio Consejo.

El artículo 141 de la Constitución estableció las siguientes atribuciones del Consejo de Estado, así:

- Actuar como cuerpo consultivo del gobierno en asuntos de administración.

- Preparar los proyectos de ley y códigos que debían presentarse a las cámaras y proponer las reformas que se juzgaran convenientes en todos los ramos de la Administración.

- Decidir sin posterior recurso, los asuntos contencioso administrativos, con arreglo a la ley que establecía esta jurisdicción. Es de anotar, que la ley que estableció la jurisdicción contencioso administrativa, debía crear una sección de lo contencioso administrativo con su respectivo fiscal.

- Llevar un registro de sus dictámenes o conceptos y resoluciones y pasar copia del mismo al Congreso por intermedio del gobierno.

- Darse su propio reglamento, el cual debía incluir el número de sesiones que se realizarían por mes, para evacuar los asuntos sometidos a su consideración ${ }^{34}$.

Como se puede ver, por primera vez se le asignaron al Consejo de Estado funciones jurisdiccionales, desligándolo así de su única función de cuerpo asesor del ejecutivo, como había sido consagrado hasta ahora; es así, que la Constitución de 1886 tiene el gran mérito de darle atribuciones de juez administrativo al Consejo de Estado, originando una verdadera jurisdicción contencioso administrativa en nuestro país, pues hasta el momento al

34 Sáchica, L. C. Constitución de la República de Colombia, artículo 141, Bogotá: Biblioteca Jurídica Dike, 1987, p. 195. 
Consejo de Estado se le había consagrado en algunas constituciones, como ente asesor o consultor del ejecutivo.

\subsection{LOS ATAQUES DE COMIENZOS DE SIGLO XX}

Para el año de 1905 se encontraba rigiendo los destinos de nuestra Patria el General Rafael Reyes, quien había llegado al poder en 1904, luego de haberse sucedido hechos de suma importancia para nuestra historia política, como lo fueron la culminación de la guerra de los mil días y la separación de Panamá; por lo que se presentaba una necesidad de unión nacional en contra de la anarquía existente. El General Reyes, pronto dejó ver su don de mando militar y tomó medidas supuestamente para mantener el orden y tolerancia entre los partidos, hecho que generó entre otras cosas que el Consejo de Estado desapareciera de la vida jurídica; es así que mediante el acto reformatorio de la Constitución número 10 de 27 de abril de dicho año ${ }^{35}$, se suprimió del ordenamiento jurídico colombiano; esta supresión constituyó un retroceso en el proceso de creación e institucionalización de la jurisdicción contencioso administrativa, ya que por primera vez a lo largo de nuestra historia constitucional, se le daba atribuciones de órgano jurisdiccional en asuntos contencioso administrativos y si se borraba del organigrama de la República, era retroceder 20 o 30 años en la evolución jurídica del país. Es de anotar que en el año 1905, hacían parte de la entonces Asamblea Nacional Constituyente entre otros los Diputados Benjamín Herrera, Baldomero Sanín Cano, Rufino Gutiérrez, Salvador Franco, Luis María Silva y Juan E. Manrique.

Por todo lo analizado, es pertinente anotar a manera de corolario, que el germen constitucional del Consejo de Estado es totalmente evidente; que si bien es cierto, en algunas de nuestras Constituciones se trató de sustituirlo por un Consejo de Gobierno o por un Consejo de Ministros, en la práctica el Consejo de Estado siguió presente como institución en la vida jurídica del país, ya que las funciones asignadas a esos nuevos consejos que pretendían remplazarlo, eran básicamente las mismas, por lo que en el fondo lo único que cambiaba era el nombre. En igual forma y como consecuencia de los vaivenes de nuestras primeras normas constitucionales, la supresión del Consejo de Estado mediante el Acto Legislativo de 1905 sólo fue transitoria,

35 “Acto Legislativo No. 10 del 27 de abril de 1905". En: Restrepo, C. Constituciones políticas nacionales de Colombia, Bogotá: U. Externado de Colombia 1955, p. 400. 
pues prontamente fue restablecido para seguir existiendo en forma continua hasta nuestros días como lo veremos más adelante.

\section{SECCIÓN SEgundA}

\section{LA PUESTA EN FUNCIONAMIENTO DEL CONSEJO DE ESTADO}

En los inicios del siglo XX por la Ley 27 de 1904 se le dio competencia al Consejo de Estado para pronunciarse sobre la validez o nulidad de las ordenanzas departamentales que fueren impugnadas por ser violatorias de la Constitución o de la ley, función esta de carácter jurisdiccional, sin que la jurisdicción administrativa se hubiera creado formalmente ${ }^{36}$; y aunque el Acto Legislativo número 10 de 1905 había suprimido el Consejo de Estado, el Acto Legislativo número 3 de $1910^{37}$, ordenó que la ley establecería la jurisdicción de lo contencioso administrativo, por lo que se expidió la Ley 130 de 1913 que revivió la figura del Consejo de Estado, asignándole funciones jurisdiccionales. En efecto, la Ley 130 de 1913 le asignó competencia al Consejo de Estado para cumplir funciones jurisdiccionales, por lo que le dio unas atribuciones específicas como tribunal de instancia. El Consejo de Estado desarrollaba su función, conociendo de los asuntos atribuidos en única instancia, en segunda instancia y a través de consulta.

Como juez de única instancia tenía las siguientes competencias:

- De los negocios sobre suministros, empréstitos y expropiaciones en tiempos de guerra.

- De las reclamaciones sobre recompensas militares.

- De las actuaciones sobre reconocimiento de pensiones conforme a la ley.

- De los asuntos relativos a la navegación marítima o fluvial de los ríos navegables, en que se ventilaban cuestiones de mero derecho administrativo, en cuanto no fueran de la competencia exclusiva de la Corte Suprema de Justicia.

- De las causas o negocios contenciosos sobre presas marítimas.

36 Rodríguez, L. Origen y evolución de la jurisdicción administrativa en Colombia, Memorias del coloquio conmemorativo del bicentenario del Consejo de Estado Francés, op. cit., p. 46.

37 “Acto Legislativo N. 3 de 1910”. En: Restrepo, C. Constituciones Políticas Nacionales de Colombia, Bogotá: U. Externado de Colombia, 1955, p. 424. 
- De las cuestiones que se suscitaran entre el Estado y uno o más departamentos o municipios sobre competencia de facultades administrativas.

- De las cuestiones que se suscitaran entre dos o más departamentos sobre competencia de facultades administrativas.

- De las cuestiones respecto a la condición de ocultos que tenían los bienes denunciados como tales, en los casos prescritos en el aparte f) del artículo 30 del Código Fiscal. El artículo 30 de la Ley 110 de 1912 establecía que para obtener esa participación, debía el interesado dirigir un memorial al ministerio respectivo en solicitud de celebración de un contrato, en el cual habían de pactarse las siguientes condiciones: f) Que si el concepto del ministerio era adverso al del denunciante, le queda a éste el derecho de acudir a la vía contencioso administrativa para que en juicio contradictorio entre él y el Estado, se decidiera acerca de la condición de oculto que tenga el bien.

- De los recursos contencioso administrativos contra las resoluciones de los ministerios que ponían fin a una actuación administrativa, con excepción de los que se originaban en contratos celebrados en nombre del Estado, pues las acciones contra estas últimas providencias sólo podían ejercitarse ante la justicia ordinaria ${ }^{38}$.

Las competencias atribuidas al Consejo de Estado como juez de única instancia, le daban la facultad de conocer los asuntos de manera directa y no como consecuencia de un recurso de alzada o a través del grado jurisdiccional de consulta; es decir, que era una atribución expresa de competencia de la ley. Pero aunque las funciones jurisdiccionales del Consejo de Estado, estaban consagradas en la Ley 130 de 1913, como consecuencia de esta ley que constituye el primer Código Contencioso Administrativo, se expidieron otras leyes en donde se le atribuyeron competencias jurisdiccionales al Consejo de Estado; es por lo que en este momento haremos relación a ellas, así:

En efecto, la Ley 38 de 1918 en el artículo $2^{39}$, contempló que el Consejo de Estado conocía de las reclamaciones contra la Nación por los hechos derivados de expropiaciones, así como de los daños en propiedad ajena como consecuencia de órdenes o providencias administrativas nacionales.

38 "Ley 130 de 1913, artículo 2o". En: Código Contencioso administrativo, Compilación arreglada por el doctor Pedro A. Gómez Naranjo, Consejero de Estado, de conformidad con el artículo $8^{\circ}$ de la Ley 116 de 1928, con la aprobación del Consejo.

39 “Ley 38 de 1918, artículo 2 ${ }^{\circ}$ ". En: Diario Oficial $N^{\circ} .16542$ de noviembre 13 de 1918. 
Posteriormente, la Ley 109 de 1923 en su artículo 1940, le atribuyó competencia al Consejo de Estado para conocer de las acusaciones que se hacían de las resoluciones que dictaba el Contralor, las cuales se hacían ante la Sala de Negocios Generales. Esta competencia de la Ley 109 de 1923 se le otorgó al Consejo de Estado en pleno, mediante la Ley 22 de 1925 artículo $2^{41}$. Tenía igualmente atribuciones de revisión de contratos celebrados por el ejecutivo, atribución que fue contemplada en el artículo 3 de la Ley 77 de $1926^{42}$, revisión que se limitaba a decidir si tales contratos se ajustaban a las respectivas leyes de autorizaciones.

También la Ley 100 de 1928, en el artículo $19^{43}$, dijo que las resoluciones que dictara la comisión de especialidades farmacéuticas, eran revisables por el Consejo de Estado y anuladas en el único caso en que desconocieran derechos civiles legítimamente adquiridos de acuerdo con la Constitución.

En cuanto a la revisión de cartas de naturaleza expedidas por el Presidente de la República, la competencia era del Consejo de Estado en virtud del artículo 2 de la Ley 16 de $1931^{44}$. Igualmente la Ley 52 de 1931, otorgó competencia al Consejo de Estado en el artículo $7^{45}$, para conocer las solicitudes que hacían los particulares para que se declarara si han cumplido o no las condiciones exigidas en el caso de adjudicación de baldíos, cuando el gobierno nacional no hacía pronunciamiento en los términos otorgados por la ley. Es de aclarar, que el término que tenía el gobierno para pronunciarse era de tres meses contados a partir de la prueba presentada por el solicitante o de las practicadas por el gobierno o de seis meses contados a partir del vencimiento del término que el solicitante tenía para probar el cumplimiento de sus obligaciones.

A su turno, en segunda instancia, el Consejo de Estado cumplía con las siguientes atribuciones específicas que constituían garantía de un debido proceso, así:

40 “Ley 109 de 1923, artículo 19”. En: Diario Oficial Nos. 19378 a 19379 de diciembre 20 de 1923.

41 "Ley 22 de 1925, artículo 2o". En: Diario Oficial $N^{\circ} .19826$ de febrero 14 de 1925.

42 "Ley 77 de 1926, artículo 3"". En: Diario Oficial $N^{\circ} .20942$ de noviembre 12 de 1928.

43 “Ley 100 de 1928, artículo 19". En: Diario Oficina $N^{\circ} .20953$ de noviembre 19 de 1928.

44 "Ley 16 de 1931, artículo 2०". En: Código contencioso administrativo, compilación arreglada por el doctor Gómez Naranjo, Pedro A. Consejero de Estado, de conformidad con artículo $8^{\circ}$ de la Ley 116 de 1928, con la aprobación del Consejo.

45 "Ley 52 de 1931, artículo 7". En: Código Contencioso Administrativo, Compilación arreglada por el doctor Gómez Naranjo, Pedro A. Consejero de Estado, de conformidad con el artículo $8^{\circ}$ de la Ley 116 de 1928, con la aprobación del Consejo. 
- De las apelaciones contra las sentencias dictadas por los tribunales administrativos seccionales, sobre la validez o nulidad de ordenanzas $\mathrm{u}$ otros actos de las asambleas departamentales que hubieran sido acusados como violatorios de la Constitución o de las leyes o lesivos de derechos civiles.

- De las apelaciones contra los actos interlocutorios o de sustanciación y las sentencias de excepciones pronunciadas por los recaudadores nacionales y los jueces de ejecuciones fiscales.

- De las apelaciones contra los autos de fenecimiento pronunciados por la Corte de Cuentas o por los tribunales administrativos seccionales.

- De las apelaciones contra las sentencias dictadas por los tribunales administrativos seccionales, en los juicios iniciados sobre el monto, distribución o asignación de los impuestos nacionales ${ }^{46}$.

La segunda instancia constituía entonces, un control de legalidad respecto de providencias dictadas en primera instancia y más que un control de la legalidad, era una revisión de esos pronunciamientos judiciales. Pero además, existían otras disposiciones que atribuían competencia de segunda instancia al Consejo de Estado, las cuales merecen ser resaltadas, así:

En efecto, la Ley 42 de $1923^{47}$, permitía que las decisiones del Contralor fueran apeladas por el agraviado ante el Consejo de Estado, dentro del mes siguiente a su expedición. A su turno la Ley 109 de 1923 en el artículo 20 contempló ${ }^{48}$, que el Consejo de Estado conocía de las apelaciones a que se refiere el artículo 7 de la Ley 42 de $1923^{49}$; es decir, sobre reorganización de la contabilidad oficial y creación del departamento de contraloría. Por su parte el Decreto 911 de $1932^{50}$, otorgaba el derecho que tenían los empleados pagadores y los contratistas de interponer recurso de apelación ante el Consejo de Estado, contra las decisiones resultantes de las revisiones de

46 “Ley 130 de 1913, artículo 18”. En: Código Contencioso Administrativo, Compilación arreglada por el doctor Gómez Naranjo, Pedro A. Consejero de Estado, de conformidad con el artículo $8^{\circ}$ de la Ley 116 de 1928, con la aprobación del Consejo.

47 "Ley 42 de 1923”. En: Diario Oficial NOS. 19119 - 19126 de julio 26 de 1923.

48 “Ley 109 de 1923, artículo 20". En: Diario Oficinal Nos. 19378 - 19379 de diciembre 20 de 1923.

49 "Ley 42 de 1923", op. cit.

50 “Decreto Nacional 911 de 1932”. En: Código Contencioso Administrativo, Compilación arreglada por el doctor Gómez Naranjo, Pedro A. Consejero de Estado, de conformidad con el artículo $8^{\circ}$ de la Ley 116 de 1928, con la aprobación del Consejo. 
cuentas efectuadas por la Contraloría General. La Ley 1 de $1931^{51}$, permitía apelar ante el Consejo de Estado las resoluciones proferidas por el Director de Higiene y Asistencia Pública. Finalmente, la Ley 79 de 1931 en el artículo $332^{52}$, permitía que las sentencias del Tribunal Supremo de Aduanas fueran apeladas ante el Consejo de Estado.

Pero además de conocer las controversias en única y en segunda instancia, el Consejo de Estado tenía unas competencias adicionales al conocer del grado de consulta, así:

- De las sentencias dictadas por los tribunales administrativos seccionales, sobre la validez o nulidad de las ordenanzas $u$ otros actos de las asambleas departamentales, cuando aquellas no hubiesen sido apeladas ${ }^{53}$. Se le había asignado igualmente al Consejo de Estado como competencia en grado de consulta, el referido a los autos absolutorios proferidos por la sala de decisión de la Corte de Cuentas. Ésta Corte quedó incorporada a la Contraloría en virtud de la Ley 42 de 1923, artículo 42.

La consulta quedó limitada, a las sentencias de primera instancia de los tribunales administrativos seccionales, respecto de las acciones sobre la legalidad de ordenanzas u otros actos de las asambleas departamentales; es decir, que cualquier otra sentencia, por ejemplo las indemnizatorias estaban excluidas de consulta. La consulta era además, una oportunidad para que el Consejo de Estado se pronunciara sobre la validez o legalidad de una sentencia de primera instancia cuando no era apelada, lo que creaba seguridad jurídica y probatoria en los fallos de los tribunales administrativos seccionales en los asuntos mencionados, pues de todas maneras, las sentencias eran revisadas por el Consejo de Estado, ya por vía de apelación o a través de la consulta.

Así las cosas, podemos darnos cuenta que las atribuciones del Consejo de Estado como juez de instancia, ya sea en única, en segunda o a través del grado de consulta, representaron claramente su puesta en marcha; en

51 "Ley 1 de 1931". En: Código Contencioso Administrativo, Compilación arreglada por el doctor Gómez Naranjo, Pedro A. Consejero de Estado, de conformidad con el artículo $8^{\circ}$ de la Ley 116 de 1928, con la aprobación del Consejo.

52 "Ley 79 de 1931, artículo 3322. En: Código Contencioso Administrativo, compilación arreglada por el Doctor Gómez Naranjo, Pedro A. Consejero de Estado, de conformidad con el artículo $8^{\circ}$ de la Ley 116 de 1928, con la aprobación del Consejo.

53 “Ley 130 de 1913, artículo 21”. En: Código Contencioso Administrativo, compilación arreglada por el doctor Gómez Naranjo, Pedro A. Consejero de Estado, de conformidad con el artículo $8^{\circ}$ de la Ley 116 de 1928, con la aprobación del Consejo. 
efecto, la Ley 130 de 1913 o primer Código Contencioso Administrativo, constituyó el punto de partida del Consejo de Estado como juez natural de la Administración. Ya no es el simple órgano asesor del ejecutivo, sino que se convirtió en su juzgador, a través del conocimiento de los diversos asuntos que por mandato legal le eran asignados. La Administración tiene formalmente a partir de este momento una jurisdicción y un juez especial que conocía de las controversias en que era parte y es lógico que así fuera, pues los principios que inspiraban su actuación también eran especiales, por tratarse de principios de derecho público. Juez y jurisdicción especial que al igual que en Francia se impusieron lentamente, con paciencia, en el marco de una dualidad de jurisdicciones que la ponían necesariamente frente a la jurisdicción ordinaria ${ }^{54}$.

\section{SECCIÓN TERCERA}

\section{PERFECCIONAMIENTO DEL CONSEJO DE ESTADO}

Bajo el gobierno de José Vicente Concha, quien gobernó Colombia entre 1914-1918 y que constituyó una figura de unión del partido conservador de la época, frente a la entrada en decadencia del denominado republicanismo que había tenido como Presidente de la República en el período anterior a Carlos E. Restrepo. Concha se constituyó en el primer Presidente elegido por voto directo después de la reforma de $1910^{55}$, la cual en palabras del profesor Rodrigo NARANJO, efectuó una importante tarea en materia de racionalización y control del poder político y por ello constituyó un hito en la construcción de nuestra democracia ${ }^{56}$. El Consejo de Estado se restableció con carácter constitucional mediante el Acto Legislativo número 10 de $1914^{57}$, recobrando su calidad de órgano asesor del ejecutivo, colegislador y de tribunal supremo de lo contencioso administrativo; estaba conformado por siete miembros, así: El primer designado para ejercer el poder ejecutivo,

54 Moderne, F. Origen y evolución de la jurisdicción administrativa en Francia, Memorias del coloquio conmemorativo del bicentenario del Consejo de Estado Francés, Bogotá: Ed. Temis, p. 38.

55 Arizmendi, I. Presidentes de Colombia 1810-1990, Bogotá: Editorial Planeta, 1989, p. 209.

56 Naranjo, R. "La reforma contenciosa administrativa de 1914". En: Revista estudios socio jurídicos, Bogotá: Universidad del Rosario, 2001, p. 30.

57 “Acto Legislativo N. 10 DE 1914, artículo 6". En: Restrepo, C. Constituciones Políticas Nacionales de Colombia, Bogotá: Ed. Universidad Externado de Colombia, 1995, p. 431. 
quien lo presidía y siete vocales cuya designación sería reglamentada por la ley. A los ministros del despacho se les asignó voz pero no voto dentro del seno del Consejo de Estado; esto es comprensible por la calidad de órgano asesor del ejecutivo que poseía.

Para ser Consejero de Estado se requerían las mismas condiciones que para ser Magistrado de la Corte Suprema de Justicia, es decir: ser colombiano de nacimiento, tener más de 35 años de edad, haber sido Magistrado de Tribunal Superior de Distrito o haber ejercido la profesión de abogado con buen crédito por cinco años o haber sido profesor de jurisprudencia en algún establecimiento público. Quienes se designaban como Consejeros de Estado no podían ejercer otro empleo público, ni la abogacía; es decir, que la actividad de Consejero era de dedicación exclusiva. El período de los Consejeros se estableció en cuatro años, los cuales eran renovados por mitad cada dos años.

El artículo $6^{\circ}$ del Acto Legislativo confirió las siguientes atribuciones al Consejo de Estado, así:

“Artículo 60. Son atribuciones del Consejo de Estado.

$1^{\circ}$. Actuar como cuerpo consultivo del Gobierno, en asuntos de administración, debiendo ser necesariamente oído en todos aquellos que la Constitución y las leyes determinen.

Los dictámenes del Consejo de Estado no son obligatorios para el Gobierno.

$2^{\circ}$. Preparar los proyectos de ley y de códigos que deban presentarse a las cámaras legislativas, y proponer las reformas convenientes en todos los ramos de la legislación.

$3^{\circ}$. Desempeñar todas las funciones de tribunal supremo de lo contencioso administrativo conforme a las reglas que señale la ley.

$4^{\circ}$. Darse su propio reglamento, con la obligación de celebrar por lo menos tres sesiones en cada semana, y las demás que les señalen las leyes" 58 .

Como se puede ver, de suma importancia para el desarrollo y evolución de la jurisdicción contencioso administrativa, constituye este acto legislativo de 1914, ya que revive la calidad de órgano supremo de lo contencioso administrativo que la Constitución de 1886 le había dado al Consejo de Estado.

58 “Acto Legislativo de septiembre 10 de 1914, artículo 6". En: Restrepo, C. Recopilación de Actos Legislativos 1914-1986, Anexo a la Obra Constituciones de Colombia de M.A. Pombo y J.J. Guerra, Bogotá: Biblioteca Banco Popular, 1986, p. 14. 
Por mandato del Acto Legislativo número 3 de 1910, la Ley 130 de 1913 creó la jurisdicción contencioso administrativa como ya se explicó, lo que dio como resultado que el Acto Legislativo de septiembre 10 de 1914 restableciera el Consejo de Estado, el cual había sido suprimido del ordenamiento jurídico colombiano mediante el Acto Legislativo número 10 de 1905.

Con la creación del Consejo de Estado ya como máximo tribunal de la jurisdicción contencioso administrativa, hubo necesidad de darle una organización adecuada para que se consolidara como máximo órgano de la jurisdicción contencioso administrativa, por lo que se dictó la Ley 60 de 1914 titulada: “Orgánica del Consejo de Estado". Mediante ésta ley se reguló lo concerniente a la integración y funcionamiento de la institución; hecho importante para el desarrollo del Jurisdicción Contencioso Administrativa, pues, como dice el profesor Gustavo Penagos:

"La Ley 60 del mismo año 1914 lo dividió en salas, la Sala de Negocios Generales, con funciones consultivas, y la Sala de lo Contencioso Administrativo. Para la Sala Plena se reservaron algunas funciones consultivas especiales.

A este Consejo de Estado se le dio inusitada importancia, pues se instaló solemnemente el 17 de diciembre de 1914, con la asistencia del Presidente de la República, de todos sus Ministros y de otros altos funcionarios del Estado.

A partir de este Acto Legislativo número 10 de 1914 se institucionaliza en Colombia la jurisdicción contencioso administrativa. Puede afirmarse que de ahí en adelante se inicia su verdadero proceso de perfeccionamiento"59.

Es así, que la Ley 60 de 1914 constituyó la consolidación definitiva del Consejo de Estado, el cual se concibió de la siguiente manera: Estaba integrado por el primer designado para ejercer el poder ejecutivo, quien lo presidía y además por seis vocales, tres designados por el Senado y tres por la Cámara de Representantes ${ }^{60}$. De la designación de los Consejeros de Estado, podemos ver que aunque era un órgano jurisdiccional por las funciones que cumplía, tenía un acentuado carácter político ya que se dejó a la Cámara y al Senado la potestad de nombramiento de sus integrantes.

59 Penagos, G. Código Contencioso Administrativo, tercera edición, Bogotá: Ediciones Librería del Profesional, 1987.

60 Ley 60 de 1914, artículo 1. En: Diario Oficial No. 15337 de noviembre 05 de 1914. 
Los Consejeros de Estado, a excepción del primer designado, tenían dos suplentes que los remplazaban en caso de faltas temporales o absolutas, quienes eran nombrados en la misma forma que los Consejeros principales. Los Consejeros eran nombrados para períodos de cuatro años, designación que se hacía por turnos cada dos años, empezando por el Senado quien eligió tres Consejeros en el primer año para un período de cuatro años y la Cámara eligió tres Consejeros, para un período de dos años ${ }^{61}$.

El Consejo de Estado para ocuparse de los asuntos que eran sometidos a su conocimiento, ya como órgano de consulta, ya como máximo tribunal de lo contencioso administrativo, se componía de dos salas: la Sala de Negocios Generales y la Sala de lo Contencioso Administrativo. La Sala de lo Contencioso Administrativo tenía asignada las funciones relacionadas con la jurisdicción de lo contencioso, es decir, que era el verdadero juez de la Administración. Esta sala que estaba integrada por cuatro Consejeros, los cuales eran nombrados por el poder ejecutivo de los designados por el Congreso; por su parte, la Sala de Negocios Generales conocía de los demás asuntos asignados a la competencia del Consejo de Estado, es decir, de los relativos a consulta; esta sala se integraba por el primer designado y por dos de los Consejeros designados por el Congreso.

El Consejo de Estado a través de la Sala de lo Contencioso Administrativo, daba el trámite correspondiente a las acciones contempladas en la Ley 130 de 1913 o sea las consagradas en el Código Contencioso Administrativo, conociendo las mismas en única o segunda instancia. Para casos específicos y en especial para dictaminar respecto de asuntos de suma gravedad o importancia, el Consejo de Estado se reunía en Sala Plena por convocatoria del presidente de la Sala de Negocios Generales.

Merece resaltarse y aunque no eran funciones jurisdiccionales, el hecho de que el gobierno debía escuchar al Consejo de Estado que se reunía en Sala Plena para dar su dictamen, en el caso de permitir el tránsito de tropas extranjeras por el territorio de la República, esto en receso del Senado, y para dejar fondear buques de guerra extranjeros en aguas de la Nación.

\section{UN CONSEJO DE ESTADO INDEPENDIENTE}

Como máximo órgano de la jurisdicción contencioso administrativa, el Consejo de Estado tenía una regulación expresa en la Ley 167 de 1941, el

${ }_{61}$ “Ley 60 de 1914, artículo 2"”. En: Diario Oficial No. 15337 de noviembre 05 de 1914. 
segundo Código Contencioso Administrativo, lo que constituyó un paso más para que la jurisdicción de lo contencioso administrativo se convirtiera en una jurisdicción autónoma, por lo que es conveniente conocerlo, para ver cuál fue el avance respecto del código de 1913.

En cuanto a su conformación, el Consejo de Estado se integraba por siete miembros dentro de los cuales estaban el Primer Designado a la Presidencia de la República, quien lo presidía y seis vocales elegidos para un período de cuatro años; designación que hacían las Cámaras Legislativas, es decir, el Senado de la República y la Cámara de Representantes. El Senado elegía tres Consejeros y la Cámara los otros tres, los cuales eran renovados por mitad cada dos años. Los Consejeros de Estado tenían dos suplentes cada uno, designados por las Cámaras en la misma forma que los principales, quienes reemplazaban a los Consejeros principales en sus faltas absolutas o temporales. El Consejo de Estado conformaba anualmente una lista de siete conjueces, destinados a llenar las faltas de los Consejeros como consecuencia de impedimentos, recusaciones o empates en las decisiones.

Tenía además unas competencias específicas como juez de instancia; tal es que, conocía de los siguientes asuntos en única instancia:

- De las controversias sobre suministros, empréstitos y expropiaciones en tiempo de guerra.

- De las indemnizaciones a cargo del Estado por causa de trabajos público nacionales.

- De los asuntos relativos a la navegación marítima o fluvial de los ríos navegables, en que se ventilan cuestiones de mero derecho administrativo.

- De los asuntos contenciosos sobre presas marítimas.

- De las controversias originadas entre el Estado y los departamentos o municipios, respecto de competencias de facultades administrativas; o entre dos o más departamentos, o entre uno de éstos y una intendencia o comisaría, por las mismas razones.

- De los asuntos respecto de la condición de ocultos que tenían los bienes denunciados como tales.

- De la decisión sobre extinción de la condición resolutoria de los baldíos nacionales.

- De los juicios de revisión de cartas de naturaleza. 
- De los procesos contra las resoluciones y actos de la Contraloría General de la República, la Superintendencia Bancaria y la Superintendencia de Sociedades Anónimas.

- De los recursos contencioso administrativos contra los decretos, resoluciones y otros actos del gobierno, de los ministros o de cualquiera autoridad, funcionario o persona administrativa del orden nacional, que ponían fin a una actuación administrativa y que no se atribuían expresamente a una jurisdicción distinta.

- De los juicios electorales, en los términos del capítulo XX de la Ley 167 de 1941; o sea, de los juicios de elección de Presidente de la República, de Senadores, Representantes y de las elecciones o nombramientos que realizaran el Congreso, la Corte Suprema de Justicia, el gobierno o cualquier otra autoridad del orden nacional ${ }^{62}$.

Es de anotar que a la Corte Suprema de Justicia se le asignó competencia especial, para que en Sala Plena y en única instancia conociera de los juicios electorales, por la elección del Designado a la Presidencia de la República, los Consejeros de Estado y los magistrados de los tribunales administrativos.

Es pertinente decir que los asuntos sometidos al conocimiento del Consejo de Estado en única instancia, se referían fundamentalmente a actuaciones de la Administración de carácter nacional, siendo esto lógico, pues por ser el Consejo de Estado el máximo tribunal de lo contencioso administrativo, debía encargarse de los asuntos de mayor importancia y trascendencia en lo relacionado con la actividad de la Administración.

Pero además, en su calidad de juez de lo contencioso administrativo, al Consejo de Estado se le asignaron unas competencias en segunda instancia, así:

- De las apelaciones o consultas de las sentencias de los tribunales administrativos, en el caso que tuvieran doble instancia.

- De las apelaciones de los autos de suspensión provisional dictados por los tribunales administrativos.

- De las apelaciones contra los autos de fenecimiento con alcance proferidos por la Contraloría General de la República, cuando el alcance ascendía a más de quinientos pesos.

62 “Ley 167 de 1941, artículo 34”. En: Diario Oficial N. 24853 de enero 07 de 1942. 
- De las apelaciones de las resoluciones proferidas por la Contraloría General de la República.

- De las apelaciones contra decisiones relativas a recompensas o pensiones ${ }^{63}$.

La competencia en segunda instancia del Consejo de Estado, se circunscribía a la revisión de decisiones ya fueran de los tribunales administrativos o de la Contraloría General de la República, esto, para determinar legalidad de los fallos y garantizar el principio de la doble instancia.

Es de anotar, que el Consejo de Estado conocía de las consultas de los litigios, estableciéndose este grado de jurisdicción por mandato expreso del artículo 36 de la Ley 167 de 1941. En igual forma, le correspondía decidir respecto de las controversias surgidas entre los tribunales por cuestiones de jurisdicción, es decir, de los conflictos de competencia; así como de los impedimentos y recusaciones de los Consejeros de Estado, de los conjueces y del secretario.

3.

\section{LA SEPARACIÓN DE FUNCIONES CONSULTIVAS Y JURISDICCIONALES}

Para el año de 1945 la vida política y administrativa del país estaba altamente convulsionada, tal es así que en el mismo año se dio un cambio de Presidente de la República en forma inesperada, pues se presentó la renuncia del titular Alfonso López Pumarejo y en su reemplazo asumió el poder Alberto Lleras Camargo, político que al igual que el anterior, era de estirpe liberal y que posteriormente se convertiría en el primer Presidente del frente nacional. Como consecuencia de esa convulsión política existente, se expidió el Acto Legislativo No. 1 de 1945, que reguló ampliamente la institución del Consejo de Estado, especialmente en los siguientes aspectos:

En cuanto a la designación de los Consejeros, esta correspondía hacerla a las Cámaras Legislativas de ternas enviadas por el Presidente de la República, dentro de las cuales debía incluirse un Consejero que se encontrara ejerciendo el cargo. Es de anotar, que se contempló la existencia de Consejeros suplentes, que también eran elegidos por las cámaras legislativas en igual forma que se hacía para los principales, siendo su obligación remplazarlos en caso de faltas absolutas o temporales. El período

63 “Ley 167 de 1941, artículo 35”. En: Diario Oficial N. 24853 de enero 07 de 1942. 
de elección de los Consejeros al igual que en el acto legislativo de 1914, era de cuatro años, siendo renovados parcialmente cada dos años.

Especial importancia se le dio a la separación de las funciones del Consejo de Estado, como órgano asesor de gobierno y como tribunal de lo contencioso administrativo, por esta razón, se consagró que se dividiría en salas o secciones para cumplir sus funciones como tribunal de lo contencioso administrativo y como órgano asesor del ejecutivo. Al igual que el acto legislativo de 1914, para ser Consejero de Estado se requerían las mismas calidades que para ser Magistrado de la Corte Suprema de Justicia.

Este acto legislativo determinó las funciones del Consejo de Estado, de la siguiente manera:

- Actuar como cuerpo consultivo del gobierno en asuntos de administración, debiendo ser necesariamente oído en todos aquellos casos que la Constitución y la ley lo señalaran. Los conceptos del Consejo de Estado no eran obligatorios para el ejecutivo.

- Preparar los proyectos de ley y de códigos que debían presentarse a las cámaras legislativas y proponer reformas convenientes en todos los ramos de la legislación.

- Desempeñar las funciones de tribunal supremo de lo contencioso administrativo

- Darse su propio reglamento ${ }^{64}$.

Especial importancia merece la función otorgada al Consejo de Estado, en el sentido de conocer de las acusaciones por inconstitucionalidad de los decretos dictados por el gobierno, cuando no eran de los expedidos en ejercicio de las facultades de los numerales 11 y 12 del artículo 69 constitucional. Es decir, cuando el Congreso otorgaba facultades al gobierno para celebrar contratos, negociar empréstitos, enajenar bienes nacionales y en el caso en que el Congreso revestía pro tempore al Presidente de precisas facultades extraordinarias, cuando la necesidad lo exigió o las conveniencias públicas lo aconsejaran. En este caso, se le atribuyó al Consejo de Estado la función de juez constitucional, además de la de juez administrativo; hecho que corroboró aún más su carácter de tribunal jurisdiccional y no sólo de cuerpo consultivo del ejecutivo.

64 “Acto Legislativo No. 1 De 1945, En: Restrepo, C. Recopilación de Actos Legislativos 1914-1986, Anexo a la Obra Constituciones de Colombia de M.A. Pombo Y J. J. Guerra, Bogotá: Biblioteca Banco Popular, 1986, p. 54. 
En igual forma, se siguió otorgando a la jurisdicción de lo contencioso administrativo la facultad de suspender los actos de la Administración en casos específicos y por las circunstancias que determinaría la ley. Recordemos, que los actos administrativos están sujetos a ser suspendidos provisionalmente, debido a lo que ARGAÑARÁs denomina propiedad ejecutiva del acto administrativo por proceder simplemente de la Administración así se ejecute o no, lo cual depende bien de la decisión de la propia Administración o de la suspensión jurisdiccional ${ }^{65}$. Esto es importante en el proceso de evolución de la jurisdicción contenciosa, puesto que era una facultad eminentemente jurisdiccional, la cual se refleja actualmente en la posibilidad que tiene dentro de ciertos requisitos, de suspender provisionalmente los actos administrativos. Es de anotar, que la figura de la suspensión provisional fue adoptada por el Acto Legislativo número 3 de 1910 en sus artículos 58 y 64, como un recurso que se otorgaba a los particulares que se consideraban lesionados por actos de las asambleas departamentales o de los concejos municipales, para acudir ante el tribunal competente con el fin de lograr la suspensión del acto. En cambio, en este acto legislativo de 1945 se contemplaba la facultad de la jurisdicción contencioso administrativa para suspender provisionalmente los actos de la Administración por los motivos que estableciere la ley, que no eran otros que la manifiesta ilegalidad del acto, si se trataba de una acción de nulidad o que constituyera agravio injustificado a un particular, si se trataba de una acción distinta de la de nulidad. La importancia de esta disposición constitucional para la jurisdicción contencioso administrativa y por tal para el Consejo de Estado, está en que le dio firmeza y lo arraigó aún más como máximo tribunal de lo contencioso administrativo y además confirmó, la separación de sus funciones jurisdiccionales de las de asesor del ejecutivo.

\section{4. \\ CRITERIOS POLÍTICOS EN LA CONFORMACIÓN DEL CONSEJO DE ESTADO}

El Decreto Legislativo número 0259 de octubre 9 de 1957, le introdujo aspectos políticos a la conformación del Consejo de Estado, que es conveniente estudiar. Se refiere a que el Consejo de Estado sería paritario, estableciéndose además que los Consejeros de Estado permanecían en sus

65 Argañarás, M. Tratado de lo contencioso administrativo, Buenos Aires: Ed. Tea, 1955, p. 245 . 
cargos mientras observaran buena conducta y no llegaran a edad de retiro forzoso. El hecho de ser paritario el Consejo de Estado, significaba que los miembros que lo integraban debían pertenecer por mitad a cada uno de los dos partidos políticos tradicionales.

Este decreto legislativo es de importancia en dos aspectos: en cuanto al período de los Consejeros, el cual se convirtió en vitalicio, siendo que en el acto legislativo de 1945 el período era de cuatro años; y en cuanto a la obligación que se imponía a que el Consejo de Estado fuera paritario, es decir, la mitad de los Consejeros de filiación política liberal y la otra mitad conservadores, se debió a una supuesta estabilidad política, administrativa y jurisdiccional que se lograría con la participación equitativa para los dos partidos tradicionales de nuestro país; lo que se reflejó igualmente en el Acto Legislativo $\mathrm{N}^{\circ} .1$ de 1959, que estableció que los 3 períodos constitucionales comprendidos entre el 7 de agosto de 1962 y el 7 de agosto de 1974, el cargo de Presidente de la República sería desempeñado o ejercido alternativamente por un Presidente liberal y uno conservador, es decir, por ciudadanos que pertenecían a los partidos tradicionales ${ }^{66}$. Dos hechos de importancia dieron lugar a que se presentara esa alternatividad en el gobierno de nuestro país: uno el Pacto de Benidorm y el otro, el Pacto de Sitges. El Pacto de Benidorm, fue firmado el 24 de julio de 1956 en la ciudad española del mismo nombre, entre el líder liberal Alberto Lleras y el conservador Laureano Gómez, dicho pacto, hace referencia, a una declaración de principios sobre la situación política de la Nación, sobre la dictadura que imperaba en la época del General Gustavo Rojas Pinilla y las posibilidades que se vislumbraban del retorno al gobierno de los civiles; en igual forma, se convino en la necesidad de un sistema de gobierno de coalición bipartidista, con el fin de derrocar del poder al mentado General Rojas Pinilla ${ }^{67}$. Por su parte el Pacto de Sitges fue firmado el 20 de julio de 1957, por Alberto Lleras Camargo y Laureano Gómez en Sitges España y en él se establecieron los pasos a seguir para establecer un gobierno de coalición una vez que se hubiera derrocado la dictadura del General Rojas Pinilla. En él se establecieron los principios básicos del frente nacional, desarrollando los acuerdos del Pacto de Benidorm, que incluía una reforma constitucional que contuviera la paridad en el gabinete ministerial y las corporaciones públicas por un período de doce años, al igual que el establecimiento de la

\footnotetext{
66 Acto Legislativo No. 1 de 1959, estableció en nuestro país, lo que se denominó Frente Nacional.

67 Enciclopedia Nueva Historia de Colombia, Bogotá: Ed. Planeta, 1989, p. 189.
} 
carrera administrativa. Planteó la necesidad de un plebiscito popular para ratificar las reformas constitucionales. Contenía la necesidad de un candidato nacional para la presidencia de la República ${ }^{68}$.

5. EL CONSEJO DE ESTADO Y LA REFORMA DE 1968

En la reforma política de 1968 de la que fue ideólogo el Presidente Carlos Lleras Restrepo, se plantearon los siguientes postulados: se transformó la estructura político institucional con el fin de fortalecer la autoridad presidencial, ampliar el poder del ejecutivo frente al legislativo, incrementar la influencia de los técnicos en las decisiones del Estado ${ }^{69}$. En efecto, la reforma político administrativa obedeció fundamentalmente a los postulados de campaña que llevaron a la presidencia de la República a Carlos Lleras Restrepo, que básicamente eran los siguientes: En primer lugar, lo referente al funcionamiento institucional, es decir, la negativa de un plebiscito para llevar a cabo las reformas; las facultades extraordinarias del artículo 121 de guerra exterior y conmoción interior o estado de sitio, como sistema normal de gobierno. En segundo lugar, la reforma como compromiso de los programas de transformación nacional. En tercer lugar, una necesidad de reformar el Congreso disminuyendo su número, optimizando su funcionamiento, acrecentando su prestigio y aumentando sus funciones de control de la Administración. En cuarto lugar, un mejoramiento en la planeación y el gasto público, para así poder utilizar adecuadamente los pocos recursos del país. En quinto lugar, una reforma al sistema de votación, para lograr recuperar el poder de decisión del Congreso. Como sexto punto, una reforma al sistema de elecciones en el sentido de modificar el cuociente electoral, para favorecer las minorías políticas; reforma solicitada por el entonces movimiento MRL o Movimiento Revolucionario Liberal. En último lugar, una reforma al régimen departamental y municipal, aumentando la descentralización administrativa y dotándolos de mayores recursos para cumplir sus funciones ${ }^{70}$. La reforma en algunos aspectos, no logró plenamente los postulados del gobierno, pero sí se constituyó en un instrumento eficaz de modernización del Estado y de sus instituciones. En cuanto a la paridad en el Congreso, se determinó que en las elecciones de

68 Ibid.

69 Ibid, p. 239.

70 Vidal, J. Historia de la reforma constitucional de 1968 y sus alcances jurídicos, Bogotá:

Publicaciones Universidad Externado de Colombia, 1970, p. 67. 
1974 los partidos políticos ocuparían los puestos que les diera su fuerza política, en aplicación del cuociente electoral. En lo referente a la paridad en la rama ejecutiva, se estableció que los ministros del despacho eran de libre nombramiento y remoción del Presidente de la República, pero se mantuvo la paridad política hasta el año de 1978, al igual que en las gobernaciones, alcaldías y demás cargos de la Administración, siempre que no fueran de carrera administrativa. En lo relacionado con la elección de diputados y concejales, se estableció que la paridad política terminaría en 1970. Es pertinente resaltar, además, que en lo relacionado con el cuociente electoral, se estableció como sistema especial de elecciones, el cual obraría plenamente en las elecciones de diputados y concejales de 1979 y de congresistas de 1974. En la misma forma, se unificó el calendario electoral y se dictaron otras disposiciones que no son del caso traer a colación, por tratarse de un estudio eminentemente procesal; pero sí es pertinente decir, que como consecuencia de esta reforma constitucional el Estado modificó muchas de sus estructuras políticas y administrativas, como se refleja en la expedición de los Decretos 3135, 2400, 1848 y otros, todos del mismo año $1968^{71}$.

En igual forma, el Consejo de Estado no fue ajeno a las reformas que sucedían en la época y por tal tuvo algunos cambios. El Acto Legislativo $\mathrm{N}^{\circ} .1$ de 1968 estableció las atribuciones del Consejo de Estado de la siguiente forma:

- Actuar como cuerpo consultivo del gobierno en asuntos de administración, debiendo ser necesariamente oído en todos aquellos que la Constitución y las leyes determinaran.

Se establecieron unos casos especiales, en que el ejecutivo debía oír previamente al Consejo de Estado en forma obligatoria, esto era en lo referente a los estados de excepción, artículos 121 y 122, en los casos de privación de la libertad de personas por serios motivos de perturbación del orden público artículo 28 y en el caso de la apertura de créditos presupuestarios adicionales, suplementales y extraordinarios artículo 212. Es de anotar que los conceptos del Consejo de Estado no eran obligatorios, salvo el caso del artículo 212, pues esta disposición contemplaba que el dictamen necesariamente debía ser favorable, para el caso de la apertura de los créditos adicionales, suplementarios y extraordinarios a que se hizo referencia anteriormente.

71 Para profundizar en todos los aspectos jurídico-políticos de la Reforma de 1968, Ver Vidal, J. Historia de la Reforma Constitucional de 1968, op. cit., pp. 65 a 171. 
- Se le asignó igualmente, la función de preparar los proyectos de ley y códigos que se debían presentar a las cámaras legislativas y proponer las reformas que fueren convenientes, en todos los ramos de la legislación. Esto como consecuencia de lo que se ha llamado función colegisladora del Consejo de Estado.

- El acto legislativo consagró como función del Consejo de Estado, la de ser tribunal supremo de lo contencioso administrativo, corroborando lo que ha venido siendo constante en las normas constitucionales, desde la expedición de la Constitución de 1886.

- Se atribuyó la posibilidad al Consejo de Estado de darse su propio reglamento ${ }^{72}$.

Las funciones otorgadas en este acto legislativo no se diferenciaron en gran medida, de las que venían siendo atribuidas en la última época al Consejo de Estado; no existió un cambio significativo.

6.

\section{LA COOPTACIÓN ABIERTA DE 1979}

Para el año de 1979, se encontraba rigiendo los destinos de la República el entonces Presidente liberal Julio César Turbay Ayala, que había derrotado en las elecciones presidenciales a las varias veces candidato conservador Belisario Betancur, quien posteriormente fue también Presidente. Su gobierno osciló entre los problemas de orden público con el movimiento guerrillero M-19 y el sonado Estatuto de Seguridad. Pero lo más destacable, desde el punto de vista jurídico, fue el derrumbe de la reforma constitucional de 1979 cuando la Corte Suprema de Justicia la declaró inexequible a finales de $1981^{73}$; pues recordemos, que para esa época el control de constitucionalidad lo ejercía la Corte Suprema, ya que no existía Corte Constitucional. Pero para los efectos de nuestro estudio, el Acto Legislativo número 1 de $1979^{74}$ contempló que el Consejo de Estado estaría integrado por el número de miembros que determinara la ley; es decir, que dejaba a la reglamentación legal de la norma constitucional, el número de Consejeros.

72 “Acto Legislativo N. 01 DE 1968". En: Restrepo, C. Recopilación de Actos Legislativos 1914-1986, Anexo a la Obra Constituciones de Colombia de M. A. Pombo \& J. J. Guerra, Bogotá: Biblioteca Banco Popular, 1986, p. 152.

73 Arizmendi, I. Presidentes de Colombia 1810-1990, Bogotá: Editorial Planeta, 1989, p. 292.

74 “Acto Legislativo N. 01 de 1979”. En: Restrepo, C. Recopilación de Actos Legislativos 1914-1986, Anexo a la obra Constituciones de Colombia de M. A. Pombo \& J. J. Guerra, Bogotá: Biblioteca Banco Popular, 1986, p. 216. 
En cuanto a los requisitos para ser Consejero de Estado, se debía tener más de 35 años de edad, ser abogado titulado y además haber sido magistrado en propiedad de la Corte Suprema de Justicia o del Consejo de Estado o Procurador General de la Nación o Fiscal General de la Nación o magistrado de tribunal superior de distrito, por un término no menor de ocho años o haber ejercido con excelente reputación moral y buen crédito por más de diez años a lo menos, la profesión de abogado o el profesorado en jurisprudencia en algún establecimiento de enseñanza.

Este acto legislativo es más expreso, en cuanto a los requisitos para ser Consejero de Estado, exigiendo no sólo preparación académica sino experiencia en cargos de alto rango del orden jurisdiccional. Es importante recalcar, además, que en la elección de los Consejeros se pasó de un sistema de cooptación cerrada a una cooptación abierta, en donde los propios Consejeros de Estado suplían las vacantes, pero de listas enviadas por el Consejo Superior de la Judicatura. Fue entonces, limitado en cierto sentido el poder del Consejo de Estado, para la elección de sus miembros.

De todo lo analizado en esta sección es pertinente afirmar, que el perfeccionamiento del Consejo de Estado como máxima institución de la jurisdicción contencioso administrativa, llevó un período largo desde que en 1914, mediante el Acto Legislativo número 10, se le restableció como juez natural de la Administración, hasta la reforma constitucional de 1979, pasando por cada una de las etapas de regulación, como fueron algunas disposiciones legales entre ellas la Ley 60 de 1914 o la Ley 167 de 1941 o cada una de las reformas constitucionales a que se hizo referencia. En este período el Consejo de Estado fue adquiriendo identidad como institución, lo que permite ver que en algunas ocasiones se muestre como un órgano en muchos aspectos imperfecto, esto es así, con lo que se presentaba en la paridad que existía en la designación de sus miembros, por ejemplo. Pero el desarrollo como tribunal jurisdiccional fue evidente, ya que sus competencias, los trámites que se surtían y sus decisiones constituyeron muestra de avance, por haberse convertido además en una institución próxima a la Administración; lo que nos permite decir con Guy Braibant, que la proximidad del juez administrativo con la Administración, le ha permitido conocerla mejor, comprenderla mejor y controlarla mejor ${ }^{75}$.

75 Braibant, G. "La jurisdicción administrativa en el derecho comparado". En: Historia y perspectivas de la jurisdicción administrativa en Francia y América Latina, Coloquio conmemorativo bicentenario del Consejo de Estado Francés, op. cit., p. 343. 


\section{SECCIÓN CUARTA}

\section{LA CONSOLIDACIÓN DEL CONSEJO DE ESTADO}

El Decreto 01 de 1984, reguló todo lo referente al Consejo de Estado en el Título XII organización de la jurisdicción de lo contencioso administrativo, Capítulo I; en donde se hizo una referencia específica al Consejo de Estado en cuanto a su integración, permanencia de los Consejeros en sus cargos, vacantes, calidades para ser Consejero, prueba de las calidades, atribuciones tanto de la Sala Plena como de las Salas de lo Contencioso Administrativo y de Consulta. En otras disposiciones de este decreto, se muestra al Consejo de Estado en cuanto a competencias, trámites o procedimientos, a los cuales no haremos referencia en esta parte, pues serán tratados cuando se analicen los asuntos jurisdiccionales sobre cada tema.

El Consejo de Estado se integraba por veinte miembros teniendo en cuenta la paridad política; es decir, la mitad del partido liberal y la otra mitad del partido conservador, como rezago del Frente Nacional; los cuales permanecerían en sus cargos mientras demostraran buena conducta y no llegaran a la edad de retiro forzoso; exigiendo las mismas calidades para ser Consejero de Estado, que las requeridas para ser Magistrado de la Corte Suprema de Justicia.

En cuanto a la organización, la corporación se integraba por tres Salas, que correspondían a la Sala Plena, la Sala de lo Contencioso Administrativo y la Sala de Consulta. Como es obvio, la Sala de lo Contencioso Administrativo, cumplía en forma especial las funciones jurisdiccionales, aunque en casos específicos lo hacía la Sala Plena. Es pertinente resaltar, el hecho de que existieran Salas Disciplinarias integradas por tres magistrados, quienes se encargaban de tramitar los procesos disciplinarios contra los magistrados de los tribunales administrativos y contra los funcionarios del Consejo de Estado.

La Sala de lo Contencioso Administrativo, se dividía en cuatro secciones integradas por cuatro Consejeros. En este caso, se respetaba en igual forma la paridad política; a cada sección se le asignaban las competencias respectivas por la Sala Plena; es decir, cada sección tenía una competencia específica de negocios, dependiendo si los asuntos eran laborales, contractuales, de impuestos, electorales, etc. Al Consejo de Estado se le asignaron funciones o competencias jurisdiccionales como ya se dijo, las cuales ejercía con atribuciones o competencia de juez de 
única o segunda instancia, según el caso; dichas funciones las pasaremos a describir en los apartes siguientes.

En única instancia, el Consejo de Estado tenía competencia en los siguientes asuntos:

- De la nulidad de los actos administrativos del orden nacional, Aquí se incluían los actos de todas las autoridades de este orden.

- De la nulidad de los contratos administrativos celebrados por las entidades públicas del orden nacional.

- De las acciones de restablecimiento del derecho de actos del orden nacional, cuando carecían de cuantía.

- De la nulidad de elección de Presidente de la Republica, Designado a la Presidencia, Senadores y Representantes.

- De los asuntos relacionados con la navegación marítima, fluvial o aérea, en donde se discutieran cuestiones de Derecho Administrativo.

- De los asuntos relativos a la condición de ocultos de los baldíos nacionales.

- De la extinción del dominio de la propiedad.

- De los actos expedidos por el Incora.

- De los asuntos referidos a actos administrativos de la nacionalidad y la ciudadanía.

- De actos referentes a asuntos petroleros y mineros en que fuere parte la Nación o una entidad territorial o descentralizada.

- De la nulidad de los laudos arbitrales sucedidos como consecuencia de los contratos administrativos.

- De los incidentes de excepciones en procesos de jurisdicción coactiva, cuando la cuantía excedía de quinientos mil pesos.

- De la definición de competencias administrativas, cuando se incluían entidades del orden nacional o de otro orden; siempre y cuando no correspondieran a la jurisdicción de un sólo tribunal administrativo ${ }^{76}$.

Como se puede ver, la competencia del Consejo de Estado en única instancia, hizo referencia especialmente a asuntos del orden nacional; esto

76 “Decreto 01 de 1984”. En, Penagos, G. Código Contencioso Administrativo, tercera edición, Bogotá: Ediciones Librería del Profesional, 1987, p. 48. 
es comprensible, el Decreto 01 de 1984 consagró competencia específica para los tribunales administrativos en asuntos diferentes de dicho orden, los cuales llegaban al Consejo de Estado por vía del recurso de apelación como juez de segunda instancia.

A su vez, como juez de segunda instancia, al Consejo de Estado se le dio la facultad o la competencia de conocer respecto de las apelaciones de las sentencias de los tribunales administrativos dictadas en primera instancia; al igual que de las consultas de las mismas, cuando procedía este grado de jurisdicción. Pero no sólo conocía de las apelaciones de sentencias, sino igualmente de autos proferidos por los mentados tribunales administrativos, en los casos del rechazo de demandas, suspensión provisional de actos administrativos o de las providencias que ponían fin a la actuación procesal; es decir, para casos de autos interlocutorios de determinada importancia.

\section{LA REFORMA DE 1989 NO IMPLICÓ TRANSFORMACIONES SUSTANCIALES}

La reforma de 1989 se presentó siendo Presidente de la República Virgilio Barco Vargas, quien representaba al partido liberal y había derrotado en las elecciones al varias veces candidato conservador y nunca Presidente Álvaro Gómez Hurtado y al candidato de la izquierda Jaime Pardo Leal ${ }^{77}$. La reforma solo hizo énfasis en el número de Consejeros y en el aumento de las secciones, pero en lo medular de la institución no existió mayor variación. En efecto, el Decreto 2289 de 1989 modificó el Decreto 01 de 1984, que para el caso específico del Consejo de Estado hizo referencia a los siguientes aspectos.

El número de Consejeros fue elevado a 30, eso sí, manteniendo todavía la paridad política, figura poco comprensible en un sistema democrático como el nuestro. El incremento en el número de Consejeros llevó a que las salas, en igual forma, incrementaran sus miembros, para lo cual la Sala de lo Contencioso Administrativo quedó integrada por veintiséis Consejeros y la Sala de Consulta por cuatro.

Especial atención merece la modificación del número de secciones, las cuales pasaron de cuatro a seis, cada una integrada por cuatro Consejeros y la segunda por seis, a las que se repartían los negocios según su naturaleza;

77 Arizmendi, op. cit., p. 302. 
es decir, si se trataban de cuestiones laborales, electorales, indemnizatorias de reparación, de impuestos, contractuales etc. Los demás aspectos a que se hizo referencia cuando se habló del Consejo de Estado en el Decreto 01 de 1984, no sufrieron mayor modificación.

\section{EL CONSEJO DE ESTADO EN LA CONSTITUCIÓN DE 1991}

La Constitución de 1991, la cual propugna por un Estado Social de Derecho y que fue el fruto de la Asamblea Constituyente convocada en el gobierno de César Gaviria, consagra el Consejo de Estado en el Título VIII denominado De la Rama Judicial, capítulo 3 De la jurisdicción contencioso administrativa $^{78}$. Esto para significar, el carácter de órgano jurisdiccional que predomina en esta institución y no como se hizo en constituciones anteriores, donde se le incluía en el título correspondiente a la rama ejecutiva, para dar a entender la prevalencia de órgano asesor del gobierno, como se consideraba al Consejo de Estado. Esta Carta Constitucional por fin rompe la paridad que existía en el Consejo de Estado y dice que estará integrado por un número impar de magistrados según lo determine la ley. Para el cumplimiento de sus atribuciones es dividido en salas y secciones, esto con el fin de separar las funciones de órgano jurisdiccional de las demás que le son atribuidas.

A su vez contempla la Constitución que el Consejo de Estado estará integrado por Consejeros, los cuales serán nombrados por la propia corporación de listas que debe enviar el Consejo Superior de la Judicatura, nombramiento que se hará para un período de ocho años sin que puedan ser reelegidos en sus cargos, permaneciendo en los mismos siempre y cuando observen buena conducta, tengan rendimiento satisfactorio y no hayan llegado a la edad de retiro forzoso. Es interesante observar, que la disposición constitucional, incluye un requisito importante para permanecer en el cargo de Consejero de Estado, como es el del rendimiento satisfactorio. Hay que aclarar, que hasta ahora no se ha retirado a ningún Consejero por su bajo rendimiento en el cargo.

Para ser Consejero de Estado se contemplaron unos requisitos, así:

- Ser colombiano de nacimiento y ciudadano en ejercicio.

- Ser abogado.

78 “Constitución de 1991, Artículo 232”. En: Ortega, J. Constitución Política de Colombia, Bogotá: Ed. Temis, 1991, p. 107. 
- No haber sido condenado por sentencia judicial a pena privativa de la libertad, excepto por delitos políticos o culposos.

- Haber desempeñado durante diez años cargos en la rama judicial o el Ministerio Público o haber ejercido con buen crédito por el mismo tiempo la profesión de abogado o la cátedra universitaria en disciplinas jurídicas en establecimientos reconocidos oficialmente ${ }^{79}$.

Es de anotar que, a diferencia de otras constituciones, no se exige una edad mínima para poder ser Consejero de Estado, pero se regula con el mínimo de experiencia en el ejercicio de la judicatura, la docencia o el ejercicio profesional.

En cuanto a las atribuciones del Consejo de Estado al artículo 237 de la Carta estableció las siguientes:

"Art. 237. - Son atribuciones del Consejo de Estado:

1. Desempeñar las funciones de Tribunal Supremo de lo Contencioso Administrativo, conforme a las reglas que señale la ley.

2. Conocer de las acciones de nulidad por inconstitucionalidad de los decretos dictados por el Gobierno Nacional, cuya competencia no corresponda a la Corte Constitucional.

3. Actuar como cuerpo supremo consultivo del Gobierno en asuntos de administración, debiendo ser necesariamente oído en todos aquellos casos que la Constitución y las leyes determinen.

En el caso de tránsito de tropas extranjeras por el territorio nacional, de estación o tránsito de buques o aeronaves extranjeras de guerra, en aguas o en territorio o en espacio aéreo de la Nación, el Gobierno debe oír antes al Consejo de Estado.

4. Preparar proyectos de actos reformatorios de la Constitución y proyectos de ley.

5. Conocer de los casos sobre pérdida de investidura de los Congresistas, de conformidad con esta Constitución.

6. Darse su propio reglamento y ejercer las demás funciones que determine la ley" ${ }^{\prime \prime}$.

79 Ibid, p. 407.

80 “Constitución de 1991, artículo 237”. En: Ortega, J. Constitución Política de Colombia, Bogotá: Ed. Temis, 1991, pp. 109 y 110. 
Como se nota, la Constitución de 1991 le ha seguido dando al Consejo de Estado el carácter de máximo tribunal de lo contencioso administrativo, hecho que le permite seguir manteniendo el carácter de órgano jurisdiccional y no sólo como cuerpo consultivo del ejecutivo, como lo fue en alguna época. Pero igualmente le dio el carácter de juez constitucional, cuando le asigna la competencia de conocer de las acciones por inconstitucionalidad de decretos del gobierno cuyo control no corresponda a la Corte Constitucional. Es entonces juez administrativo y juez constitucional.

3.

EL CONSEJO DE ESTADO EN LA ACTUALIDAD. LEY 270 DE 1996, LEY 446 DE 1998 Y ACUERDOS DE SALA PLENA

En la actualidad, el Consejo de Estado es considerado como parte integrante de la estructura general de la administración de justicia. Es así, que el artículo 11 de la Ley 270 de 1996, Estatutaria de la Administración de Justicia establece:

“Art. 11. La rama judicial del poder público está constituida por:

1. Los órganos que integran las distintas jurisdicciones.

a) De la jurisdicción ordinaria...

b) De la jurisdicción de lo contencioso administrativo.

1. Consejo de Estado.

2. Tribunales administrativos.

3. Juzgados administrativos. ... $" 81$.

En cuanto a su actividad como juez de la Administración, el Consejo de Estado ejerce función jurisdiccional en los términos del artículo 12 de la Ley Estatutaria de la Administración de Justicia, la que ejerce como propia y habitual y de manera permanente, como consecuencia de la investidura constitucional y legal de la cual ha sido dotado, junto con los demás órganos de la rama judicial, como la Corte Suprema de Justicia, la Corte Constitucional, el Consejo Superior de la Judicatura, etc.

$\overline{81}$ "Ley 270 de 1996, artículo 11". En: Revista anexa al Código Contencioso Administrativo, Bogotá: Ed. Legis, 1996. 
Determinado el carácter del Consejo de Estado como órgano perteneciente a la rama jurisdiccional del poder público, como máximo órgano de la jurisdicción contencioso administrativa, es necesario que miremos su composición, sus integrantes, sus atribuciones, sus funciones.

\subsection{CONFORMACIÓN DEL CONSEJO DE ESTADO}

El Consejo de Estado está integrado por 31 magistrados, quienes son elegidos por la misma corporación de listas que son enviadas por el Consejo Superior de la Judicatura, los cuales conforman tres salas mediante las cuales cumple las funciones que le han sido asignadas.

Las salas que integran la Corporación son las siguientes: la Sala Plena, que está integrada por todos los magistrados; la Sala de lo Contencioso Administrativo, integrada por 27 magistrados y la Sala de Consulta integrada por 4 magistrados.

\subsubsection{Sala de lo Contencioso Administrativo. La Sala de lo Contencioso Administrativo se divide en 5 secciones, así:}

- Sección primera, integrada por cuatro magistrados. Esta sección conoce de los procesos de simple nulidad de actos administrativos, procesos de nulidad y restablecimiento del derecho que versen sobre asuntos no asignados a otras secciones, del recurso de revisión contra las sentencias de única instancia dictadas por los tribunales administrativos, en los asuntos relacionados con la competencia de ella y además, conoce de los procesos donde no exista regla general de competencia.

- Sección segunda, integrada por seis magistrados. Esta sección se divide en dos subsecciones de tres magistrados. La sección conoce de los procesos de simple nulidad de actos administrativos, procesos de nulidad y restablecimiento del derecho relacionado con asuntos laborales, de los recursos de revisión de las sentencias de única instancia dictadas por los tribunales administrativos en asuntos laborales y de los demás actos vinculados con las relaciones de trabajo.

- Sección tercera, integrada por nueve magistrados. Esta sección conoce de los procesos de simple nulidad en asuntos contractuales mineros, petroleros y agrarios, conflictos de carácter contractual, acciones de reparación directa, 
acciones de extinción de la condición resolutoria de los baldíos nacionales, del recurso de revisión contra las sentencias de única instancia dictadas por los tribunales administrativos, en los asuntos relacionados con la competencia de esta sección.

- Sección cuarta, integrada por cuatro magistrados. A esta sección se le ha asignado conocer de los procesos de simple nulidad y los de nulidad y restablecimiento del derecho que versen sobre impuestos y contribuciones, procesos de nulidad y nulidad y restablecimiento del derecho distintos a los de carácter laboral, respecto de actos expedidos por entidades como el Consejo de Política y Social, Superintendencias etc.

- Sección quinta, integrada por cuatro magistrados. Esta sección conoce de los procesos de simple nulidad electoral y revisión contra estos mismos actos ${ }^{82}$.

\subsubsection{Funciones de la Sala de lo Contencioso Administrativo.}

La Ley Estatutaria de la Administración de Justicia, ha establecido unas funciones específicas de la Sala de lo Contencioso Administrativo, las cuales se refieren a la calidad de órgano jurisdiccional que tiene el Consejo de Estado y son de vital importancia para nuestro tema de estudio, relacionado con el Jurisdicción Contencioso Administrativa en nuestro país.

Las funciones que cumple la Sala de lo Contencioso Administrativo, son las siguientes:

- Resolver los conflictos de competencia entre las secciones del Consejo de Estado, los tribunales administrativos y las secciones de los tribunales administrativos y entre los tribunales y jueces de la jurisdicción de lo contencioso administrativo pertenecientes a los diferentes distritos judiciales administrativos y entre jueces de los diferentes distritos judiciales administrativos. Esta función es lógica, si tenemos en cuenta que el Consejo de Estado es el máximo órgano de la jurisdicción contencioso administrativa.

- Conocer de todos los procesos contenciosos administrativos cuyo juzgamiento atribuya la ley al Consejo de Estado y que no se hayan asignado a las secciones. Si se trata de la Sala de lo Contencioso Administrativo, es necesario que conozca de los asuntos contencioso administrativos.

82 Sala Plena del Consejo de Estado, Acuerdos 2 de 1971; 1 de 1978; 39 de 1990. 
- Elaborar cada dos años la lista de auxiliares de la justicia. Esto para asuntos específicos de competencia del Consejo de Estado.

- Resolver los asuntos extraordinarios que sean de su competencia. Aquí podemos hablar del recurso extraordinario de súplica.

- Resolver los asuntos que le remitan las secciones por su importancia jurídica o trascendencia social. En este caso se trata de una función subsidiaria, pues está determinada a que las secciones le envíen los asuntos por considerarlos de importancia y además a que la Sala Plena de lo Contencioso decida asumir la competencia, pues es facultativo.

- Conocer de los procesos que le remitan las secciones, para cambiar o reformar la jurisprudencia de la corporación. Porque la jurisprudencia del Consejo de Estado debe ser uniforme y sólo puede ser modificada por decisión de Sala Plena de lo Contencioso Administrativo.

- Conocer de los casos de pérdida de investidura de los congresistas, de conformidad con la Constitución y la ley. Las sentencias que ordenen la pérdida de la investidura deberán ser aprobadas por los miembros de la Sala Plena y por las causales establecidas taxativamente en la Constitución. Es de aclarar, que se había contemplado que la decisión de pérdida de investidura debía ser tomada por las dos terceras partes de la Sala Plena, pero fue declarada inexequible por la Corte Constitucional ${ }^{83}$.

- Conocer de los recursos de apelación contra las sentencias dictadas por la sección de asuntos electorales, en los casos que determine la ley. La Corte Constitucional declaró inexequible la expresión de apelación dentro de esta facultad concedida a la Sala Plena de lo Contencioso Administrativo. En efecto, la Corte Constitucional dijo a este respecto lo siguiente:

“...En otras palabras, el hecho de que la Carta Política hubiese facultado al legislador para determinar las materias de que deba conocer el Consejo de Estado, en particular la Sala Plena de lo Contencioso Administrativo, no significa que las secciones pierdan su competencia o que la Sala Plena sea superior de alguna de ellas. Así, pues, deberá declararse la inexequibilidad de la expresión 'de apelación', contenida en el numeral en comento, sin que ello signifique -conviene aclararlo-restringir la posibilidad de que el legislador establezca la procedencia de otros recursos como el de súplica" 84 .

\footnotetext{
83 Corte Constitucional. Sala Plena, Sentencia C-037 de febrero 05 de 1996, M.P. Vladimiro Naranjo Mesa. 
- Conocer de las acciones de nulidad por inconstitucionalidad de los decretos expedidos por el gobierno nacional, cuya competencia no corresponda a la Corte Constitucional. En este caso, se le está atribuyendo funciones de juez constitucional al Consejo de Estado ${ }^{85}$.

\subsubsection{Competencia del Consejo de Estado}

- Sala de lo Contencioso Administrativo. Actualmente la competencia del Consejo de Estado como juez de lo contencioso administrativo, está determinada en los artículos 149 y 150 del Código de Procedimiento Administrativo y de lo Contencioso Administrativo; competencia que ejerce en única instancia, en segunda instancia y en asuntos enviados por las secciones.

La competencia en única instancia, se sigue circunscribiendo al conocimiento de asuntos del orden nacional, en cuanto a la anulación de actos expedidos por autoridades de dicho orden, al igual que el conocimiento de las acciones por elección de los altos dignatarios como el Presidente de la República, senadores, representantes; así como los nombramientos y elecciones realizados por el Presidente de la República, la Corte Suprema de Justicia, el Consejo de Estado, el Congreso, la Cámara, la Fiscalía General de la Nación y en general los realizados por autoridades del orden nacional. Mención especial debe hacerse, en cuanto a la competencia en única instancia que desde la Ley 446 de 1998 se le asignó al Consejo de Estado del conocimiento de las acciones de repetición que se ejerzan contra el Presidente de la República, senadores y representantes, ministros, directores de departamentos administrativos, Procurador General de la Nación, Contralor General de la República, Fiscal General de la Nación, magistrados de las altas cortes y de los tribunales superiores. Competencia que es nueva respecto de las ya analizadas, como consecuencia de la implementación de la acción de repetición en nuestro ordenamiento jurídico, pues en lo demás, la competencia es muy similar a la ya estudiada, en cuanto a que le corresponde conocer de asuntos de orden nacional y de reconocida importancia. Consideramos que no es necesario especificar cada uno de los asuntos de competencia y en su lugar, recomendamos la remisión a los artículos 149 y 150 del CPACA ${ }^{86}$.

\footnotetext{
85 “Ley 270 de 1996, Artículo 37”. En: Revista anexa al Código Contencioso Administrativo, Bogotá: Ed. Legis, 1996.

86 Código Contencioso Administrativo, Bogotá: Ed. Legis, año 2002, pp. 236 y 237.
} 
Es bien importante la competencia que le asiste a la Sala de lo Contencioso Administrativo, del conocimiento de los asuntos que las secciones le envíen por su reconocida importancia o trascendencia social, cuando dichos asuntos se encuentren para fallo. Esto se debe a que las decisiones que se tomen implican interés de carácter general, lo que amerita un pronunciamiento de la Sala Plena de lo Contencioso Administrativo.

La competencia en segunda instancia, con la entrada en vigencia de La Ley 1437 de 2011, siguió determinándose por el conocimiento de la apelación de sentencias proferidas por los tribunales administrativos en primera instancia y de los autos susceptibles de dicho recurso, al igual que los recursos de queja, cuando la apelación no es concedida o se concede en efecto diferente. En esencia, la variación no es significativa respecto de la competencia ya estudiada; haciendo alusión además, que le compete igualmente conocer del grado jurisdiccional de consulta.

La esencia de la competencia del Consejo de Estado en los asuntos asignados a la Sala de lo Contencioso Administrativo, ha mantenido una línea de uniformidad desde la expedición del Decreto 01 de 1984, eso sí, con las modificaciones del constante devenir del Jurisdicción Contencioso Administrativa, en cuanto a la entrada en vigencia de nuevas acciones o medios de control y nuevos los actuales criterios de competencia previstos en la Ley 1437 de 2011.

\subsubsection{Sala Plena del Consejo de Estado}

La Sala Plena del Consejo de Estado, está compuesta por todos los Consejeros que integran la corporación y sus funciones se encaminan a dos clases de asuntos: unos administrativos y otros encaminados a emitir ciertos conceptos que le han sido asignados por mandato constitucional.

\subsubsection{Funciones de la Sala Plena del Consejo de Estado}

La Ley Estatutaria de la Administración de Justicia, ha establecido unas funciones específicas de la Sala Plena del Consejo de Estado, así:

- Elegir los Consejeros para proveer los nuevos cargos que se creen, llenar las vacantes de conformidad con la Constitución o la ley. 
- Elegir el Secretario General y demás empleados de la corporación, con excepción de los de las salas, secciones y despachos, los cuales son elegidos por cada una de aquéllas o por los respectivos Consejeros.

- Elegir conforme a la ley, a los miembros del Consejo Nacional Electoral.

- Proveer las faltas temporales del Contralor General de la República.

- Distribuir mediante acuerdo, las funciones de la Sala de lo Contencioso Administrativo, que no deban ser ejercidas en pleno, entre las secciones que la constituyen, con base en un criterio de especialización y de volumen de trabajo.

- Integrar las comisiones que deba designar de conformidad con la ley o el reglamento.

- Hacer la evaluación del factor cualitativo de la calificación de servicios de los magistrados de los tribunales administrativos, que servirá de base para la calificación integral.

- Darse su propio reglamento.

- Elegir de terna enviada por la Corte Suprema de Justicia para períodos de dos años, al Auditor ante la Contraloría General de la República o a quien deba remplazarlo en sus faltas temporales o absolutas, sin que en ningún caso pueda reelegirlo ${ }^{87}$.

Las anteriores funciones, hacen referencia principalmente a temas administrativos y de nombramiento de ciertos funcionarios.

En cuanto a sus atribuciones de rendir concepto en determinados asuntos, están contempladas en las normas constitucionales y en el reglamento del Consejo de Estado, así:

Emitir concepto motivado para que el Presidente de la República permita en receso del Senado, el tránsito de tropas extranjeras por el territorio de la República (artículo 189 num.7 C. N.). El actual reglamento del Consejo de Estado en el artículo 4 literal i, hace referencia, a que la Sala Plena debe emitir concepto motivado en los casos de los artículos 28, 120 ordinal 10, 121, 122 y

87 “Ley 270 de 1996, artículo 35”. En: Revista anexa al Código Contencioso Administrativo, Bogotá: Ed. Legis, 1996. 
212. Hay que dejar claridad, que estas disposiciones se refieren a la Constitución de 1886, las cuales fueron modificadas por la Constitución de 1991.

\subsubsection{Sala de Consulta.}

La Sala de Consulta hace parte de la estructura del Consejo de Estado y es la encargada de absolver los cuestionamientos que se le formulen por parte del gobierno, para efectos del adecuado funcionamiento de la Administración pública, en temas específicos y de trascendencia para el país.

La Sala de Consulta cumple las siguientes funciones:

- Absolver las consultas jurídicas generales o particulares que le formule el gobierno nacional.

- Preparar los proyectos de ley y de códigos que le encomiende el gobierno nacional. El proyecto, se entregará al gobierno por conducto del ministro o director de departamento administrativo correspondiente, para su presentación a la consideración del Congreso.

- Revisar los contratos y conceptuar sobre las cuestiones jurídicas relativas al servicio civil, en los casos previstos por la ley.

- Conceptuar sobre los contratos que se proyecten celebrar con empresas privadas colombianas, escogidas por concurso público de méritos en los casos especiales autorizados por la ley, para efectuar el control fiscal de la gestión administrativa, nacional.

- Verificar de conformidad con el Código Electoral, si cada candidato a la Presidencia de la República reúne o no los requisitos constitucionales y expedir la correspondiente certificación.

- Ejercer las demás funciones que le prescriban la Constitución y la ley ${ }^{88}$.

Así las cosas, podemos decir que la confirmación del Consejo de Estado como máximo órgano de la jurisdicción contencioso administrativa, se dio principalmente con la expedición del tercer Código Contencioso Administrativo, es decir, con el Decreto 01 de 1984, pero que se ha ratificado con la llegada de la Ley 1437 de 2011, que lo han regulado en forma detallada estableciendo su conformación, su competencia y los trámites como juez de

88 "Ley 270 de 1996, artículo 38”. En: Revista anexa al Código Contencioso Administrativo, Bogotá: Ed. Legis, 1996. 
instancia. Pero esa confirmación también se encuentra en la Constitución de 1991, que lo consagra en el título referente a la administración de justicia, dándole una importancia igual a la de los demás órganos jurisdiccionales, como la Corte Suprema de Justicia y la Corte Constitucional.

Es pertinente decir también, que el Consejo de Estado constituye el fiel reflejo de la jurisdicción contencioso administrativa, pues además de ser el máximo órgano de esta jurisdicción, ha contribuido de una manera esencial en su desarrollo, ya que con sus decisiones ha hecho que evolucione y se afiance dentro del ordenamiento jurídico colombiano. Recordemos, que la jurisdicción contencioso administrativa, ha sido y es, lo que las decisiones del Consejo de Estado han querido que sea.

En igual forma y a manera de conclusión del escrito que nos ha ocupado en estas páginas, es posible afirmar, que el origen y la evolución de la Jurisdicción de lo Contencioso Administrativo, se ha visto marcado por una serie de acontecimientos de carácter histórico-políticos, que han determinado su génesis y desarrollo, dando lugar a que lo jurisdiccional sea el producto de la realidad imperante. Nadie puede desconocer, los acontecimientos de la Revolución Francesa de 1789, como signo de vital importancia en la creación del derecho que nos ocupa; y qué decir de la época bolivariana, que con la creación del Consejo de Estado en nuestro país, contribuyó a que la jurisdicción contencioso administrativa llegara a nuestra vida jurídica. Esto sin desconocer, cada uno de los antecedentes constitucionales que fueron estudiados. En fin, el Jurisdicción Contencioso Administrativa es el producto de las realidades históricas, sociales, políticas, económicas y de intereses de una sociedad a lo largo de cada momento de su existencia. Pero si nos dedicáramos a escudriñar, qué institución o qué acontecimiento constituyó la piedra angular para el origen y el desarrollo de la jurisdicción contencioso administrativa o el Jurisdicción Contencioso Administrativa, necesariamente tendremos que decir que fue el Consejo de Estado, quien se ha convertido en la mayor fuente de evolución de la jurisdicción que nos ocupa y en el juez de la Administración, así en un principio y como lo recuerda Franck Moderne, hubiese sido creado como una asamblea política y no como un juez administrativo, no para juzgar a la administración sino para colaborarle, para aconsejar al ejecutivo y ayudarle a resolver sus dificultades ${ }^{89}$; pero el Consejo de Estado, logró con sus conceptos de orden administrativo en un principio y sus decisiones jurisdiccionales posteriormente, convertirse

89 Moderne, F. “Origen y evolución de la jurisdicción administrativa en Francia”. En: Memorias del coloquio conmemorativo del bicentenario del Consejo de Estado Francés, op. cit., p. 3. 
en el máximo órgano de la jurisdicción particular que controla la actividad de la Administración.

\section{BIBLIOGRAFÍA}

Argañarás, M. (1995). Tratado de lo contencioso administrativo, Buenos Aires: Ed. Tea. Arizmendi, I. (1989). Presidentes de Colombia 1810-1990, Bogotá: Editorial Planeta.

Braibant, G. La jurisdicción administrativa en el derecho comparado. En Historia y perspectivas de la jurisdicción administrativa en Francia y América Latina, Coloquio conmemorativo bicentenario del Consejo de Estado Francés.

Enciclopedia Nueva Historia de Colombia (1989). Bogotá: Ed. Planeta.

Ensor, R.C.K. Jueces y tribunales en Francia y Alemania, Traducción de Emilio Gómez.

Galindo, J. C. (2003). Lecciones de Derecho Procesal Administrativo, Bogotá: Pontificia Universidad Javeriana.

Gómez, P. (1934). El Consejo de Estado, Bogotá: Imprenta Nacional.

Moderne, F. Origen y evolución de la jurisdicción administrativa en Francia. En Memorias del coloquio conmemorativo del bicentenario del Consejo de Estado Francés.

Naranjo, R. (2001). “La reforma contenciosa administrativa de 1914”. En Revista estudios socio jurídicos, Bogotá: Universidad del Rosario.

Palacios, M. Colombia país fragmentado, país dividido, Bogotá.

Penagos, G. (2000). Derecho Administrativo Parte General, (segunda edición actualizada), Bogotá: Ediciones Librería El Profesional.

Pombo, M. A. \& Guerra, J. J (1986). Constituciones colombianas, T. III, Bogotá: Ed. Biblioteca Banco Popular.

Rodríguez L. Origen y evolución de la jurisdicción administrativa en Colombia, Memorias del coloquio conmemorativo del bicentenario del Consejo de Estado Francés.

Sáchica, L. C. (1987). Constitución de la República de Colombia, artículo 141, Bogotá: Biblioteca Jurídica Dike.

Vedel, G. (1980). Derecho Administrativo, Madrid: Editorial Aguilar.

Vidal, J. (1970). Historia de la reforma constitucional de 1968 y sus alcances jurídicos, Bogotá: Publicaciones Universidad Externado de Colombia. 



\title{
PERSPECTIVA DE LAS TECNOLOGÍAS DE LA INFORMACIÓN Y DE LAS COMUNICACIONES EN EL BLOQUE DE CONSTITUCIONALIDAD EN COLOMBIA*
}

\author{
Javier Eduardo Rocha Amarís* \\ Diego Fernando PeÑa PeÑA ${ }^{* * *}$
}

\section{INTRODUCCIÓN}

En tiempos actuales, cuando se avanza y se desarrolla la vida en medio de la era digital, que además de temas de tecnología implica, en el presente trabajo, esas formas de impacto social que refleja el hecho de la transformación y cambio de vida que experimenta la humanidad en términos de sociedad de la información, donde se ejercen los derechos se contraen y asumen obligaciones por a través de las Tic's, junto con nuevos derechos como el de relacionarse electrónicamente con la administración genera la necesidad de repensar el uso y el modo de los medios electrónicos y la protección tradicional de los derechos fundamentales.

De la protección constitucional que se concrete en materia de derechos fundamentales afectados en el ejercicio de las Tic's, por parte de la legislación de un Estado, hace que como sociedad de la información, se pueda aplicar criterios de la ética de la tecnología y que como Nación se adquiera conciencia de la enorme presión e influencia que los soft law, en

\footnotetext{
* El presente capítulo de libro es producto del proyecto de investigación titulado: Diseño de Procedimiento Administrativo Electrónico en Colombia, por el cual el Doctor Javier Eduardo Rocha obtuvo el titulo de Magister en la Universidad Externado de Colombia.

** Magister en Derecho Administrativo de la Universidad Externado de Colombia. Docente e Investigador del Centro de Investigaciones de la Facultad de Derecho de la Universidad Santo Tomas (Sede Bogotá). Correo Electrónico: rochadoctorado@ gmail.com

*** Candidato a Magister en Derecho Publico en la Universidad Santo Tomas. Docente e Investigador del Centro de Investigaciones de la Facultad de Derecho de la Universidad Santo Tomas (Sede Bogota). Correo Electrónico: diego.magister@hotmail.com
} 
forma de protocolos tecnológicos se incorporan en las legislaciones y se vuelven normas para aplicar en los estados, sin ningún tipo de reparos o análisis de eventuales vulneraciones de derechos.

Lo anterior solo puede ser posible, en la medida que se elabore un estudio de derechos que hacen parte del bloque de constitucionalidad. Para luego abordar un análisis de casos, en los cuales este tipo de derechos se encuentra en amenaza o en riesgo y, podamos plantear los fundamentos legales de la protección constitucional en el ámbito de derechos que se ejercen con utilización de las Tic's.

I.

PERSPECTIVA DE LAS TECNOLOGÍAS DE LA INFORMACIÓN Y DE LAS COMUNICACIONES EN EL BLOQUE DE CONSTITUCIONALIDAD EN COLOMBIA

Uno de los principales retos que se ha identificado en el derecho comparado $^{90}$, tiene que ver con las dificultades en la protección de los derechos fundamentales, lo cual se aplica al ejercicio de derechos por medio de las Tecnologías de la Información y las Comunicaciones, por el hasta ahora escaso desarrollo jurisprudencial dedicado al tema. Debido a lo que, se espera de la jurisprudencia constitucional y ordinaria que estas vayan experimentando una adaptación al tema de acuerdo con los cambios que se presentan y que en consecuencia arrojan otras realidades.

La perspectiva de las Tecnologías de la Información y de las Comunicaciones en el bloque de constitucionalidad en Colombia, se ha desarrollado jurisprudencialmente a partir de las sentencias de la Corte Constitucional donde ha sido, a raíz de algunos casos específicos, donde la alta corporación ha entrado a definir, como responde nuestro ordenamiento jurídico a los retos que como Nación tenemos ante los avances científicos y tecnológicos. Sin que en Latinoamérica a la fecha se cuente con una fundamentación teórica que sirva como protección de los derechos fundamentales en el ejercicio de los derechos por medios electrónicos.

Sin lugar a equivocarnos, podemos sostener que la forma de hacer los negocios en el mundo y la manera de efectuar las comunicaciones es lo que demarca los fenómenos de los grandes cambios culturales. Lo anterior

90 Roig, Antoni. Derechos Fundamentales y TIC'S, Barcelona: Bosch Editor, 2010, pp. 11 a $13 .$. 
desde luego aunado a las nuevas invenciones en materia de tecnología y de comunicaciones.

Es así como con el surgimiento de las prácticas de comercio electrónico entre comerciantes de todo el mundo; la desbordante tendencia de la comunidad global por el cambio en la forma de ejercer sus comunicaciones por medios tecnológicos; y las nuevas gestiones y relaciones de los gobiernos locales y nacionales con los ciudadanos, tienen en común dos grandes aspectos como son, el uso de las tecnologías de la información y las comunicaciones en las formas de hacer los negocios, y de las relaciones de las personas entre sí y con las instituciones del Estado, lo cual se traduce en nuevas prácticas sociales donde los seres humanos no pueden quedar sin una protección constitucional a sus derechos fundamentales. Aspectos hasta hace poco no regulados por el derecho y con muchos vacíos aun por llenar.

Dicha protección Constitucional resulta válida, toda vez las tecnologías de la información y las comunicaciones tuvieron su aparición en el mundo, como meros adelantos científicos cuyo nivel de incorporación en la vida para las actividades de la humanidad nunca se previó que tuviera tales dimensiones, que hasta la forma de relacionarse los ciudadanos con las instituciones del Estado y la forma de ejercer sus derechos y de contraer sus obligaciones hoy en día y cada vez en mayor medida, se hacen por medio de tecnologías. En consecuencia resulta válida a la luz del derecho plantear una protección a los derechos fundamentales por aplicación de las Tic's.

\section{PROTECCIÓN CONSTITUCIONAL A DERECHOS FUNDAMENTALES, EN EL EJERCICIO DE DERECHOS POR MEDIO DE TIC'S}

En desarrollo del tema de una perspectiva constitucional de las Tic's en el bloque de constitucionalidad en Colombia, podemos señalar que la forma de ejercer derechos y de contraer obligaciones por medio de las tecnologías le han implicado retos a las ciencias del derecho, tanto así que el máximo órgano Constitucional ha reconocido que los adelantos científicos y tecnológicos ${ }^{91}$ le han significado esfuerzos al derecho. Esfuerzos y retos

$91 \quad$ En Sentencia de la Corte Constitucional, C-1147 de 2001, al resolver sobre la demanda de inconstitucionalidad del artículo 91 de la Ley 633 de 2000, "Artículo 91. Todas las páginas web y los sitios de internet de origen colombiano que operan en el internet y cuya actividad económica sea de carácter comercial, financiera o de prestación de servicios, deberán inscribirse en el registro mercantil y suministrar a la Dirección de 
que pueden ser de tipo argumentativo y en el sentido de construir una línea de garantía y protección de los derechos fundamentales ante el uso de las Tic's para la expedición y comunicación de actos administrativos entre otras maneras de comunicarse legalmente, la administración con los ciudadanos.

Es así como el reconocimiento a un nuevo espacio de acción de la humanidad, con las tecnologías de la información y las comunicaciones al servicio de la función pública, la reflexión del personaje el Señor K, de la novela El Castillo, del escritor Franz Kafka, exhibe una administración cambiante y en donde en la atención al ciudadano inciden factores climáticos, culturales y hasta cierto grado de sensibilidad del funcionario público hacía las labores propias de su cargo, se presentaba la administración, allá arriba con su grandeza inextricable, y una persona quien solicita una petición administrativa:

“...se somete, por ejemplo, a ese proceso, tiembla durante años por los resultados, y por todas partes le preguntan con asombro, desde el primer día, cómo puede atreverse a hacer algo desesperado; él, sin embargo, confia, ¿cómo podría vivir si no?, pero al cabo de muchos años, tal vez ya anciano, se entera de que lo han rechazado, se entera de que todo se ha perdido y de que su vida ha sido inútil"'92.

Ahora con los conceptos de sociedad de la información, ahí donde se crean nuevos de espacio de acción, se configuran nuevos escenarios de protección debido a que los seres humanos y las sociedades en su interacción suelen generar conflictos y nuevos espacios de corrección y de distribución en el derecho. Nacen así, la protección constitucional por vulneración de derechos fundamentales en la interacción por medio de las Tic's y en el ejercicio de derechos de raigambre constitucional por estos medios.

Impuestos y Aduanas Nacionales, DIAN, la información de transacciones económicas en los términos que esta entidad lo requiera" con ponencia del M.P. Dr. Manuel José Cepeda Espinosa de fecha 31 de octubre de 2001, señaló: “Los avances de la humanidad en los campos científico y tecnológico siempre han planteado retos al derecho. El desarrollo de nuevas técnicas de producción y el desenvolvimiento de complejas formas de comunicación, por citar tan sólo dos ejemplos, tienen efectos directos en la estructura política y económica de la sociedad, que, de acuerdo con su grado de incidencia en el tráfico jurídico, en la distribución de bienes y servicios escasos y en el ejercicio de los derechos fundamentales de las personas, demandan diferentes respuestas del ordenamiento jurídico".

92 Kafka, F. El Castillo, Barcelona: Ramdom House Mondadori, S.A., Miguel Sáenz, 2004, p. 246. 
Se habla entonces de que el aspecto virtual de la comunicación, y de la expedición de actos administrativos, no implica una virtualización de los derechos que se regulan o se comunican a través de Tic's. Surge -en el contexto definido por la Corte- la exigencia para el juez constitucional de velar por que las actuaciones administrativas ejercidas en sede del ciberespacio para que estas se hagan respetando las garantías mínimas y los derechos fundamentales.

En materia de producción jurisprudencial al tema objeto de estudio, los cargos del actor estaban encaminados a reprochar una presunta vaguedad y lo genérico del texto del artículo 91 de la Ley 633 de 2000, y al hecho de nuevas exigencias con las cuales deberían cumplir los sitios web dedicados de carácter comercial, financiero y de prestación de servicios, la sentencia de la Corte Constitucional C-1147 de $2001^{93}$ conforme la demanda propuesta en ese entonces se concentró en resolver el problema jurídico en el interrogante de si:

“La consagración de los deberes de inscripción en el registro mercantil y de remisión de la información tributaria que solicite la DIAN a las páginas o sitios web de origen colombiano mediante las que se prestan servicios personales, comerciales y financieros, constituye una violación del principio de reserva de ley que establece la Constitución en ciertas materias como la relativa al derecho a la intimidad garantizado por el artículo 15 Superior?".

Para resolver el anterior interrogante la Corte consideró, que la normatividad demandada, se ocupaba de los deberes que en los aspectos comerciales y tributarios, se prestaban por medios electrónicos, esto es en el nuevo espacio cuya creación adjudicamos en internet, de tal manera que esa nueva forma de la actividad mercantil y hacer los negocios se constituye como un nuevo espacio materia de regulación para que el Estado ejerza su función a través de sus instituciones -DIAN- y solicite información que las actividades en esos nuevos escenarios ahora se presentan. De manera

93 Corte Constitucional, M.P. Dr. Manuel José Cepeda Espinosa, sentencia de fecha treinta y uno (31) de octubre de dos mil uno (2001), Referencia: expediente D-3495, Actor: Manuel Enrique Cifuentes Muñoz. Se trata de la demanda de inconstitucionalidad contra el artículo 91 de la Ley 633 de 2000 “por la cual se expiden normas en materia tributaria, se dictan disposiciones sobre el tratamiento de los fondos obligatorios para la vivienda de interés social y se introducen normas para establecer las finanzas de la rama judicial". Temas: Registro mercantil y comercio electrónico. Facultades de la administración tributaria - transacciones en Internet Intimidad y habeas data principio de relevancia y finalidad. 
que la Corporación encuentra legítimo, que se cree la obligación para quienes ejercen actividad económica y financiera por las páginas web deben hacerse inscribir en el registro mercantil y colaborar con el suministro de la información comercial que requiera la DIAN.

Lo anterior en observancia del derecho comparado, donde se encontró que siempre que se desarrolle una actividad comercial, es responsabilidad del comerciante, del prestador del servicio o agente financiero, ya sea que la actividad se desarrolle en espacio físico o virtual, será la persona que resultara llamado a responder por las obligaciones que se deriven de ejercer dicha actividad comercial.

En consecuencia, en la ponderación de derechos trazada entre los derechos fundamentales invocados como de Habeas Data y a la Intimidad, que según el actor se vulnerarían al reportar la información de los movimientos financieros, da cuenta que dicha información solicitada no vulnera tales derechos como quiera que esa obligación ya existe para las actividades mercantiles que se adelantan de manera física, y en consecuencia se resolvió declarar exequible el artículo 91 de la Ley 633 de 2000, en el entendido de que la norma al reglamentar los nuevos espacios donde la DIAN puede requerir información, para el cumplimiento de sus funciones y en ejercicio de sus competencias, no vulnera derechos fundamentales.

\section{PROTECCIÓN CONSTITUCIONAL AL DERECHO A LA INTIMIDAD Y AL HABEAS DATA}

En la sentencia en estudio C-1147 de 2001 en las actividades comerciales, laborales y en general que se desarrollen vía internet, resulta plausible, propender por la protección del derecho a la intimidad ${ }^{94}$ y la observancia

94 Constitución Política de Colombia, el derecho a la intimidad y al Habeas Data se encuentra regulado en el Artículo 15.- Todas las personas tienen derecho a su intimidad personal y familiar y a su buen nombre, y el Estado debe respetarlos y hacerlos respetar. De igual modo, tienen derecho a conocer, actualizar y rectificar las informaciones que se hayan recogido sobre ellas en bancos de datos y en archivos de entidades públicas y privadas. Concordante con: Ley 1010 de 2006; Ley 1266 de 2008; Ley 1288 de 2009 y Ley 1581 de 2012. En la recolección, tratamiento y circulación de datos se respetarán la libertad y demás garantías consagradas en la Constitución. La correspondencia y demás formas de comunicación privada son inviolables. Sólo pueden ser interceptadas o registradas mediante orden judicial, en los casos y con las formalidades que establezca la ley. Para efectos tributarios o judiciales y para los casos de inspección, vigilancia e intervención del Estado podrá exigirse la presentación de libros de contabilidad y demás documentos privados, en los términos que señale la ley. 
de la garantía del habeas data de los usuarios de esta modalidad de comunicación, de donde a las voces de la sentencia en estudio, resulta que se constituyen en garantías susceptibles de protección, en razón a la naturaleza del internet y a las especificaciones del medio masivo de comunicación en el que se ejercen dichos derechos.

Fíjese bien que en la sentencia en estudio la Corte resalta la necesidad que se protejan las garantías mínimas fundamentales a quienes confiando en la seguridad de la puesta en marcha de la actividad estatal a través de internet, reportan a la DIAN su actividad comercial y mercantil a través del cumplimiento de la exigencia del envío de este tipo de información requerida.

La exigencia de tal protección a la intimidad en la información suministrada, sería para las instituciones del Estado en este caso para la DIAN. Aunado a lo anterior surge el Derecho de Habeas Data, consistente en que la información recaudada no va a ser utilizada para fines distintos de los originalmente previstos o invocados en la norma, lo cual merece un responsable en la entidad que recoge la información y un estándar de dichos datos los cuales deberán ser ciertos, íntegros y de trascendencia para los fines en que la información fue requerida.

De tal forma que en el juicio de razonabilidad y de proporcionabilidad efectuado al contenido de la norma demandada, la Corte Constitucional examinó que el deber de informar a la DIAN de las actividades comerciales prestadas por internet, como la exigencia de que sometan a registro mercantil, se encuentra ajustada a derecho, por cuanto se trata de las mismas obligaciones que tienen los comerciantes que operan en el ámbito físico o no virtual, encontrándose que existe una identidad y correspondencia entre el espíritu de la norma demandada y la norma superior.

Lo relevante para el presente estudio, es que la Corte identificó que la preocupación sobre la cual había que hacer especial énfasis es que, en este caso lo que está en disputa es la protección del contexto de los datos electrónicos por medio del cual se está ejerciendo una actividad comercial, y no así para que no se cumpla con la obligación legal de proporcionar la información que, para el cumplimiento constitucional de la DIAN así le sea requerida a los comerciantes por medios electrónicos. Con lo cual se quiere recalcar que dicho cumplimiento que hace a quienes desarrollen actividades financieras y comerciales por internet, son los mismos que se piden para este tipo de actividades llevadas a cabo de manera física o de forma tradicional con observancia de las normas y disposiciones constitucionales. 
Desde la doctrina española se ha dado tratamiento al tema de la diferencia que plantea una protección del derecho a la intimidad, con respecto a la protección de los datos personales ${ }^{95}$. Y se ha sostenido que mientras con la protección del derecho a la intimidad se quiere salva-guardar la esfera personal y familiar, con la protección de los datos personales lo que se trata es de garantizar a los ciudadanos que la información y datos suministrados - a una entidad de derecho público o privado- sea usada para los fines que se recogió y no tendrá otro destino que el trámite en la entidad recaudadora de dicha información. Lo anterior en virtud de las nuevas interpretaciones que se debe hacer de ciertos derechos, ahora en la era de la información digital, cuyos cambios le imponen retos a las ciencias del derecho.

Se encuentran incluidos dentro de la protección de datos personales, los datos de la intimidad y demás información que identifica y que únicamente interesa a esa persona. En consecuencia como quiera que la puesta en marcha del ejercicio de derechos por medio de las tecnologías y con las nuevas formas de contraer obligaciones con la utilización de dichos medios, se pueden ver afectados y transformados derechos tradicionales, como es el caso que explica Antoni Roig donde la abstención del derecho a la libertad se torna en tiempos actuales en el derecho a la protección de datos, es entonces cuando se hace necesario ir avanzando en la protección constitucional de derechos fundamentales cuya lesión tenga como escenario las Tic's.

\section{PERSPECTIVA DE LA PROTECCIÓN CONSTITUCIONAL DE LOS DERECHOS EN INTERNET $^{96}$}

La puesta en marcha del ejercicio de derechos y la prestación de servicios de la administración por medio de las tecnologías de la información y de las comunicaciones, para que sea posible en Colombia como la conocemos hoy en día, y algunas propuestas del presente trabajo para desarrollar en

95 Roig, A. Derechos Fundamentales y TIC'S, Barcelona: Bosch Editor, 2010, pp. 16. En este aparte en relación a las "facultades, cuyo ejercicio impone deberes de hacer a los poderes públicos: el derecho a requerir previo consentimiento para la recogida de los datos, el derecho a ser informado sobre el destino y uso de los datos. Esta evolución en la interpretación del artículo 18.4 CE no supone un cambio en cuanto a los contenidos o haz de facultades reconocidos a la libertad informática, ahora llamada con más precisión derecho a la protección de los datos personales."

96 Santofimio, J. O. Procedimientos administrativos y tecnología; Bogotá: Universidad Externado de Colombia; 2011; pp. 177 y 178. 
aplicaciones, para poner al servicio a los usuarios actuaciones administrativas ante las distintas entidades del Estado, con el fin de garantizar el derecho a relacionarse de manera electrónica de los ciudadanos con la administración pública; demarcan la observancia de una complejidad de disposiciones constitucionales que encontramos en el desarrollo de los primeros setenta (70) artículos de la carta magna.

La protección del derecho a la intimidad y al habeas data, en el marco de la puesta en marcha de unas funciones del ejercicio de la actividad administrativa y de las comunicaciones legales por medios electrónicos con la administración, más los derechos constitucionales del Estado para con los ciudadanos al desarrollo ético de la ciencia y la técnica, son argumentos de justificación legal necesarios desarrollar las disposiciones de la Constitución Política de contenido relevante para el estudio Constitucional de las Tic's, a saber:

a) Hoy es posible a partir de las Tecnologías de la Información y las comunicaciones, que un pensamiento se difundido a mayor población y en menor tiempo que lo que podía experimentarse con anterioridad a la conformación de la Internet, como canal masivo de comunicación. Es así como el cable interoceánico termina convirtiéndose en un invento que sin duda cambió la forma de la vida de la humanidad, lo cual en conjunto con un invención inspirada en la técnica de lo digital, planteó una nueva era de la civilización de la humanidad.

ARTículo 20. Se garantiza a toda persona la libertad de expresar y difundir su pensamiento y opiniones, la de informar y recibir información veraz e imparcial, y la de fundar medios masivos de comunicación. Estos son libres y tienen responsabilidad social. Se garantiza el derecho a la rectificación en condiciones de equidad. No habrá censura.

b) La dinámica del gobierno electrónico debe cambiar, tornarse más amigable, ágil, clara, segura, interactiva y que de verdad sirva para agotar unas instancias en la petición de derechos en sede administrativa, con la correspondiente interposición de los recursos que pueden ser susceptibles de ser notificado por medios electrónicos.

ARTículo 23. Toda persona tiene derecho a presentar peticiones respetuosas a las autoridades por motivos de interés general o particular y a obtener pronta resolución. El legislador podrá reglamentar su ejercicio ante organizaciones privadas para garantizar los derechos fundamentales.

c) El Ministerio de la Educación y de las Tecnologías de la Información y de las Comunicaciones, dará cuenta del fomento que a nombre del Estado 
se haga de la educación como un servicio público buscando integrar a los procesos educativos la ciencia y la técnica.

ARTículo 67. La educación es un derecho de la persona y un servicio público que tiene una función social; con ella se busca el acceso al conocimiento, a la ciencia, a la técnica, y a los demás bienes y valores de la cultura. d) Por disposición Constitucional, al Estado le compete la promoción y los incentivos que se hagan hacia la comunidad propendiendo a la enseñanza científica y técnica, facilitando a través de organismos como Colciencias que se estimule la investigación en ciencia y en tecnología.

ARTículo 70. El Estado tiene el deber de promover y fomentar el acceso a la cultura de todos los colombianos en igualdad de oportunidades, por medio de la educación permanente y la enseñanza científica, técnica, artística y profesional en todas las etapas del proceso de creación de la identidad nacional. La cultura en sus diversas manifestaciones es fundamento de la nacionalidad. El Estado reconoce la igualdad y dignidad de todas las que conviven en el país. El Estado promoverá la investigación, la ciencia, el desarrollo y la difusión de los valores culturales de la Nación.

e) Las estrategias de inversión en promociones culturales, de ciencia y tecnología, para que tengan mayor sustento a la hora de aplicar por parte de las administraciones, se dispone que deben ser incluidas en los planes de desarrollo de las propuestas de planes de gobierno.

ArTículo 71. La búsqueda del conocimiento y la expresión artística son libres. Los planes de desarrollo económico y social incluirán el fomento a las ciencias y, en general, a la cultura. El Estado creará incentivos para personas e instituciones que desarrollen y fomenten la ciencia y la tecnología y las demás manifestaciones culturales y ofrecerá estímulos especiales a personas e instituciones que ejerzan estas actividades.

Para el año de 2010, el estado del arte en el derecho comparado, relativamente en el caso del Derecho Español, se permitió identificar que para ese momento no se contaban con las bases de las nuevas interpretaciones de los derechos fundamentales vulnerados en tiempos de la interacción y ejercicio de derechos por medio de las nuevas tecnologías. Lo anterior se debe a dos aspectos en concreto ${ }^{97}$ :

i.) Capacidad de interpretar el nivel de razonabilidad en el uso de las nuevas tecnologías.

$97 \quad$ Roig, A., ob. cit., pp. 18 y 19. 
En tiempos donde en Europa se habla de los ciberderechos y la Declaración de Derechos del Internet del Senado Español, hay que capacitar a los jueces administrativos como juez del Estado en la apreciación de los derechos a comunicarse por medio de Tic's como parte de la sociedad de la información.

ii.) Los escasos mecanismos y los poco efectivos para salvaguardar el interés general. Es la necesidad de imponer el interés general, al interés particular en temas de TIC's. La doctrina en cita, sustenta como el derecho a la intimidad puede ser vulnerado en aras a la garantía y el uso de las etiquetas de radiofrecuencia (RFID), los cuales se tratan dispositivos consistentes el laminas donde se almacena información con los cuales se marcan objetos con el fin de que su paso de un sitio a otro sea leído y en general una información sea registrada por un sensor de lectura. De uso común en los grandes almacenes de cadena, es el dispositivo que se le instala a los productos con el fin que sean registrados y vigilados en todo momento. Además de almacenes su uso se puede dar instalado en medios de comunicación para hospitales, aeropuertos, entre otros espacios masivos y de grandes áreas, donde citando al autor, los objetos físicos adquieren una identidad digital. De manera que para desarrollar el tema de los riesgos y vulneraciones en este punto, podemos enunciar, los problemas de seguridad que se suelen presentar en un mecanismo de identificación y de información portátil, en las empresas, en el caso de que se presenten interceptaciones de comunicaciones, falsificaciones de datos y de información bancaria por ejemplo, si es un medio de comunicación hay que tener en cuenta que se cuente con mecanismos de prueba distintos a la misma identificación.

En los casos de usos de estos dispositivos de almacenamiento de información se empleen por trabajadores en áreas empresariales, deberá constar un aplicativo o protocolo para el uso y manejo de la información por parte de la empresa. Esto es que se conformen una reglas claras y se identifique a la persona que se haga responsable de la manejo de este tipo de tecnologías.

A manera de impacto sociológico, se plantea que si cada vez se cargan en mayor proporción de datos del perfil de un trabajador, en esa misma medida en podrá contarse con mayor información personal de un trabajador, tornándose un espacio sensible, propenso a la vulneración de derechos fundamentales, donde deben desarrollarse a la manera de reglamentos internos del uso y manejo de dicha información, siendo la tecnología guarda de derechos y de los limites en ese adecuado manejo de la información. 
Otros ámbitos hacía donde se debe extender la protección de los derechos fundamentales por uso de las tecnologías, es hacia el espacio de la utilización de las tecnologías en la labor sindical, y la privacidad en las redes sociales.

\section{AVANCE TECNOLÓGICO A TRAVÉS DE LA CIENCIA Y TECNOLOGÍA}

En la actualidad resulta con escasa difusión los mecanismos constitucionales por medio del cual puede hacerse exigible, o por lo menos para tener en cuenta los medios por los cuales se puede hablar de un fundamento constitucional de planes de inversión, fomento ${ }^{98}$ y gestión en las áreas de tecnología y ciencia. Es así como en cabeza de COLCIENCIAS, reside las misiones antes descritas y el papel de la incorporación de la promoción de los planes para propender a la desarrollo de la nación a través de sus políticas y programas a mediano plazo al desarrollo.

De manera que para el cumplimiento en Colombia, del mandato legal contenido en los artículos 70 y 71 de la Constitución Política fueron asignadas funciones a cargo de Colciencias, que es la institución encargada tanto del fomento de la ciencia y de la tecnología como de la internacionalización de la educación y de elevar los estándares en estos ámbitos, siendo que al referirse la Corte Constitucional en la sentencia antes citada, a las misiones asignadas a Colciencias precisó:

"La labor de Colciencias"9 está orientada a promover el avance científico y tecnológico, incorporar la ciencia y la tecnología a los planes y programas de desarrollo económico y social del país y formular planes de ciencia y tecnología para el mediano y el largo plazo. También establece los mecanismos de relación entre las distintas actividades de desarrollo científico y tecnológico y las que, en los mismos campos, realicen la universidad, la comunidad científica y el sector privado colombianos y la propia entidad, Colciencias.

$98 \quad$ En la sentencia de tutela T-677 de 2004, la Corte Constitucional, con ponencia del Dr. M.P. Gerardo Monroy Cabra, Referencia: T-845134, Peticionario: Natalia Palacios Rojas y otros, Accionado: Colciencias e Icetex, en sentencia del 15 de julio de 2004 preciso: "El Estado tiene el deber de garantizar el fomento a la ciencia y la tecnología como un instrumento eficaz para consolidar y materializar el derecho a la educación, cuya función social (art. 67) incluye el crear condiciones que posibiliten a los individuos desenvolverse en un contexto social en el cual los principios de heterogeneidad y pluralismo que caracterizan a nuestra Constitución se orientan hacía la construcción de un orden social inclusivo”. 
Su acción se dirige a crear condiciones favorables para la generación de conocimiento científico y tecnológico nacionales; a estimular la capacidad innovadora del sector productivo; a orientar la importación selectiva de tecnología aplicable a la producción nacional; a fortalecer los servicios de apoyo a la investigación científica y al desarrollo tecnológico; a facilitar la apropiación pública del conocimiento; a consolidar el Sistema Nacional de Ciencia y Tecnología ${ }^{100}$-SNCYT-, y, en general, a incentivar la creatividad, aprovechando sus productos en el mejoramiento de la calidad de vida de los colombianos".

Por su parte el Consejo de Estado también ha aportado al tema de la protección constitucional en el ejercicio de actividades relacionadas con la TIC's, y para el caso en concreto contribuye al tema de la protección por vía jurisprudencial, de los derechos fundamentales cuando se ejercen derechos por los medios tecnológicos. Es así como al conocer del recurso de apelación dentro del trámite de la segunda instancia de una tutela, la sección primera del Consejo de Estado ${ }^{101}$ para garantizar los derechos fundamentales en la utilización de los medios tecnológicos, analizó y consideró el hecho que el demandante en su escrito de demanda registró como dirección para recibir notificaciones, el correo electrónico, correo a donde el juzgado omitió enviar el estado notificándole de la decisión de indamitir la demanda, como también el estado donde se notificó el auto que rechazó el proceso por no subsanación en tiempo, contrariando con ello lo dispuesto en el artículo 201 de la Ley 1437 de 2011. Lo anterior aunado al hecho de que la oficina de reparto judicial

100 [15] http://www.corteconstitucional.gov.co/relatoria/2004/T-677-04.htm\#_ftn15

101 Consejo de Estado, Sala de lo Contencioso Administrativo Sección Primera, sentencia de acción de tutela de fecha 6 de diciembre de 2012, C.P. Dra. María Elizabeth García González, Ref.: Expediente núm. 2012-00463-01; Actores: Julián Calderón Palacio y otros. Accionado: Juzgado Veintidós Administrativo del Circuito de Medellín. Se interpuso para solicitar la declaratoria de nulidad de actuaciones judiciales proferidas por el juzgado accionado dentro del proceso de reparación directa de radicación 0500133-33-022-2012-00093-00, según la providencia del H. C. de E., el actor imputo a la decisión judicial atacada cargos de "vulneración de los derechos constitucionales fundamentales al debido proceso, al acceso a la Administración de Justicia, a la igualdad de los ciudadanos ante la Ley y a la confianza legítima, habida cuenta de que, a juicio del actor, el Juzgado Veintidós Administrativo del Circuito de Medellín, cometió errores al momento de realizar la notificación de los autos que inadmitieron y rechazaron la demanda, teniendo en cuenta que por un lado, se hizo un registro equivocado de los nombres de algunos de los demandantes y por otro, se omitió enviar el mensaje de datos que establece el artículo 201 de la Ley 1437 de 2011, situación que le impidió conocer a tiempo las providencias e interponer los recursos procedentes". 
y la secretaría del juzgado accionado por un error involuntario, terminaron alterando el nombre de la demandante, persona que identificada las partes en el proceso, haciéndose una notificación con errores en el nombre del demandante.

En virtud de lo anterior el actor solicita el amparo de sus derechos fundamentales al debido proceso, al acceso a la Administración de Justicia, a la igualdad de los ciudadanos ante la Ley y a la confianza legítima, y en consecuencia la nulidad de las decisiones judiciales en comento. Amparo al que accedió el Tribunal Administrativo de Antioquia en primera instancia.

Para la segunda instancia el Consejo de Estado tuvo en cuenta que el accionante sustentó, que con la falta de notificación en la dirección de su correo electrónico aportada con el escrito de demanda, y ordenada en el reciente Código de Procedimiento Administrativo y de lo Contencioso Administrativo (CPACA), la autoridad judicial accionada vulneró sus derechos fundamentales y le impidió conocer a tiempo las providencias dictadas dentro del proceso contentivo de la acción de reparación directa. Razones por las cuales el Consejo de Estado al desatar el recurso de apelación de la acción de tutela interpuesta, encontró configurado el error procedimental de las decisiones judiciales atacadas y confirma la decisión del Tribunal con fundamento en los siguientes señalamientos:

“...en lo que hace referencia al envío del mensaje de datos, estipulado en el artículo 201 de la Ley 1437 de 2011, la Sala comparte la posición del Tribunal Administrativo de Antioquia, que en buena hora señaló que dicha norma contempla una obligación para los funcionarios judiciales, consistente en remitir un correo electrónico cuando se produzca una notificación por estado, a las personas que hubiesen suministrado la información para tal finalidad, y su omisión genera una vulneración inexplicable de los derechos fundamentales al debido proceso y a la defensa de las personas a las cuales hay que remitirle la misma.

En efecto, el artículo 201 de la Ley 1437 de 2011, dispone lo siguiente:

“Artículo 201. Notificaciones por estado. Los autos no sujetos al requisito de la notificación personal se notificarán por medio de anotación en estados electrónicos para consulta en línea bajo la responsabilidad del Secretario. La inserción en el estado se hará el día siguiente al de la fecha del auto y en ella ha de constar:

1. La identificación del proceso.

2. Los nombres del demandante y el demandado.

3. La fecha del auto y el cuaderno en que se halla. 


\section{La fecha del estado y la firma del Secretario.}

El estado se insertará en los medios informáticos de la Rama Judicial y permanecerá allí en calidad de medio notificador durante el respectivo día.

De las notificaciones hechas por estado el Secretario dejará certificación con su firma al pie de la providencia notificada y se enviará un mensaje de datos a quienes hayan suministrado su dirección electrónica.

De los estados que hayan sido fijados electrónicamente se conservará un archivo disponible para la consulta permanente en línea por cualquier interesado, por el término mínimo de diez (10) años.

Cada juzgado dispondrá del número suficiente de equipos electrónicos al acceso del público para la consulta de los estados." (Subrayado y negrillas fuera de texto original).

En el caso objeto de controversia, los autos que inadmitieron y rechazaron la demanda, eran providencias susceptibles de notificación por estado, razón por la cual, era obligatorio para el Juzgado Veintidós Administrativo del Circuito de Medellín, cumplir la norma transcrita y enviar el correspondiente mensaje de datos al señor Julián Calderón Palacio, toda vez que en el acápite de notificaciones contenido en la última hoja de la demanda de reparación directa de la cual era apoderado, se había suministrado el correo electrónico juliancalderonpalacio@hotmail.com.

El Juzgado Veintidós Administrativo del Circuito de Medellín, en su defensa, argumentó que el aquí actor no aceptó expresamente que se le notificara por este medio electrónico, como lo dispone el artículo 205 de la Ley 1437 de 2011 y por tanto, no existía obligación de remitir el señalado mensaje de datos.

Para desvirtuar este fundamento, es necesario transcribir lo señalado en el artículo 205 de la Ley 1437 de 2011, que dispone:

"Artículo 205. Notificación por medios electrónicos. Además de los casos contemplados en los artículos anteriores, se podrán notificar las providencias a través de medios electrónicos, a quien haya aceptado expresamente este medio de notificación.

En este caso, la providencia a ser notificada se remitirá por el Secretario a la dirección electrónica registrada y para su envío se deberán utilizar los mecanismos que garanticen la autenticidad e integridad del mensaje. Se presumirá que el destinatario ha recibido la notificación cuando el iniciador recepcione acuse de recibo o se pueda por otro medio constatar el acceso del destinatario al mensaje. El Secretario hará constar este hecho en el expediente. 
De las notificaciones realizadas electrónicamente se conservarán los registros para consulta permanente en línea por cualquier interesado".

La Sala advierte que el inciso primero del artículo transcrito, es claro en manifestar que su aplicación es adicional a la de los artículos anteriores, entre los cuales se encuentra el artículo 201, que consagra la obligación de la remisión del mensaje de datos cuando efectivamente se hubiese suministrado la dirección de correo necesaria, por lo que no se entiende en qué se basa el referido Despacho Judicial, para indicar que debe haber una aceptación expresa, cuando son normas que regulan situaciones totalmente diferentes.

Es pertinente resaltar que el artículo 201 establece la obligación de enviar un mensaje de datos de las notificaciones hechas por estado, a quienes hubiesen suministrado la información respectiva para tal fin, situación que bajo ningún punto de vista requiere autorización expresa o especial, más allá de la anotación de la dirección electrónica a la cual se remitirá el señalado mensaje de datos. Cosa distinta es lo establecido en el artículo 205 de la Ley 1437 de 2011, que regula un evento adicional en el que se debe remitir la providencia propiamente dicha, el cual sí requiere la aceptación expresa de la notificación por medios electrónicos".

\section{CONCLUSIONES}

En este primer capítulo a manera de conclusión podemos plantear que, en razón a la interacción en la era digital y al nuevo espacio que el internet presenta para las comunicaciones legales de los ciudadanos, de la sociedad de la información, en vista de un nuevo escenario para el ejercicio de derechos y para contraer obligaciones, se hacen necesarias nuevas regulaciones para los derechos fundamentales que se vean vulnerados en las nuevas dinámicas que traen consigo el acceder a la administración con la implementación de medios tecnológicos. Por consiguiente la jurisprudencia constitucional tendrá que amparar nuevas formas de amenazas a los derechos fundamentales con ocasión a los nuevos espacios para ejercer los derechos.

El panorama tendrá que ser abordado desde el ejercicio de los derechos sindicales, relaciones laborales, tecnología; el derecho a la intimad y protección de datos con las tic's en todo momento, recopilando y portando datos de información personal en las empresas en los tiempos de la administración electrónica.

La crítica en relación a que no hay una fundamentación jurídica actualmente para garantizar la protección de los derechos fundamentales, 
sino que las TIC's son percibidas como factores de riesgo para los derechos en general, y la propuesta de que se consolide un estándar internacional de privacidad en las redes sociales, como marco regulador de estos asuntos, son grandes tesis que se comparten del autor de los Derechos Fundamentales y Tecnologías de la Información y de las Comunicaciones (TICs), Antoni Roig quien desde España, se encuentra en el punto adecuado desde donde puede presentar la propuesta al parlamento de la comunidad Europea.

Como la anterior, su idea de que la práctica del internet y en especial la transacción entre los derechos de los usuarios y la red social, a cambio de beneficios, transforma la esencia de los derechos fundamentales en pretensiones particulares, el autor, abarca varios puntos donde las Tic's tienen rango de acción y para las cuales identifiqué algunos escenarios de investigación.

En parte los objetivos con el presente trabajo van encaminados hacia la reflexión sobre esos estándares tecnológicos que como especies de soft law se diseñan, se elaboran, producen y se imponen como determinadas tecnología, muchas veces sin tener en cuenta una eventual vulneración de derechos fundamentales y los mecanismos constitucionales para reaccionar a tiempo, antes que unos estándares y una tecnología resulte lesiva, inadecuada, para implementar en el ejercicio de funciones estatales.

Hay que profundizar en los estudios de sociología de la tecnología, retomando temas como los de la ética en la tecnología, los cuales es posible en la medida que se concrete y se fundamente una protección de los derechos fundamentales en los crecientes proyectos de tecnología en el país, para que desde ya, se incorporen la dimensión de estos derechos en lo que puede ser toda la arquitectura y diseño de la sistematización de las funciones del estado a través de las TIC's, procurando llegar más allá de una notable preocupación que trae Antoni Roig, concerniente a evitar que lleguemos al punto de que un regulación legal y de protección a los derechos fundamentales se vea desplazada por un soft law de un protocolo y estándar tecnológico.

\section{BIBLIOGRAFÍA}

Bauzá, F. J. (2002). Procedimiento Administrativo Electrónico, Granada-España: Editorial Comares de ciencia jurídica.

Brewer, A. R. (2005). Derecho Administrativo Tomos I y II, primera edición, Bogotá D.C.: Universidad Externado de Colombia y Universidad Central de Venezuela. 
Cerillo, A., Valero, J. \& Villaverde, I. (2006). La administración y la Información, Madrid: editorial apdcat y Marcial Pons.

Del Peso, E. (2003). Servicios de la Sociedad de la Información - Comercio electrónico y protección de datos, Madrid- España; Díaz de Santos S.A.

Fernández, R. (2001). Contratación Electrónica: La prestación del consentimiento en Internet, Barcelona-España: Bosch Editor - Pedro Brosa $\&$ Asociados.

Fernández, J. J. (2004). Gobierno Electrónico: un desafio en internet (implicaciones juridicas), México: FUNDAP Fundación Universitaria de Derecho, Administración y Políticas S.C.

García, E. \& Fernández, T. R. (2006). Curso de Derecho Administrativo Tomos I y II, Décima Edición, Madrid España: Thomson-Civitas.

Kafka, F.(2004). El Castillo, Barcelona: Ramdom House Mondadori, S.A., Miguel Sáenz.

Penagos, G. (2001). El Acto Administrativo, Tomo I y II, séptima edición, Bogotá D.C.: Ediciones librería del profesional.

Pérez M. (2003). Gobierno Digital-tendencias y desafios, primera edición, Bogotá D.C.: Universidad Externado de Colombia.

Rincón, E. (2006). Contratación Electrónica, Colección Lecciones de Jurisprudencia, primera edición, Bogotá D.C.: Centro editorial Universidad del Rosario.

Rivero, R. (2007). El Expediente Administrativo de los legajos a los soportes electrónicos, primera edición. Navarra España: Thomson Aranzadi.

Rodríguez, L. (2000). Derecho Administrativo General y Colombiano, Bogotá D.C.: Temis, duodécima edición.

Roig, A. (2010). Derechos Fundamentales y TIC'S. Barcelona: Bosch Editor, .

Sánchez, C. A., Ibáñez, O. \& Cabanzo D. (2010). La Teoría del acto administrativo en Colombia y Las Tecnologías de la Información y las Comunicaciones, Universidad Sergio Arboleda y Biblioteca Jurídica Dike.

Santofimio, J. O. (2004). Tratado de Derecho Administrativo, edit. Universidad Externado de Colombia.

—. (2011). Procedimientos administrativos y tecnología; Bogotá: Universidad Externado de Colombia.

Tafur, Á. (1975). Teoría del Acto Administrativo, Bogotá: Ediciones Rosaristas.

Universidad Externado de Colombia (2005). Convenio Unesco - Guía de Gobierno Electrónico Local: Servicios electrónicos orientados al ciudadano, Bogotá D.C., primera edición agosto. 
Constitución Política de Colombia, artículo 15.- Derecho a la intimidad y al Habeas Data.

http://www.corteconstitucional.gov.co/relatoria/2004/T-677-04.htm\#_ftn14 11

http://www.corteconstitucional.gov.co/relatoria/2004/T-677-04.htm\#_ftn15

Sentencia de la Corte Constitucional, M.P. Dr. Manuel José Cepeda Espinosa, 31 de octubre de 2001, Referencia: expediente D-3495, Actor: Manuel Enrique Cifuentes Muñoz.

Sentencia Acción de Tutela, Consejo de Estado, Sala de lo Contencioso Administrativo Sección Primera, 6 de diciembre de 2012, C.P. Dra. María Elizabeth García González, Ref.: Expediente núm. 2012-00463-01; Actores: Julián Calderón Palacio y otros. Accionado: Juzgado Veintidós Administrativo del Circuito de Medellín

Sentencia de tutela T-677 de 2004, la Corte Constitucional, con ponencia del Dr. M.P. Gerardo Monroy Cabra, Referencia: T-845134, Peticionario: Natalia Palacios Rojas y otros. 



\title{
PRECEDENTE ADMINISTRATIVO \\ EN COLOMBIA: APROXIMACIÓN A UN MODELO DE UNIFICACIÓN JURISPRUDENCIAL*
}

\author{
Diego Hernán Morales SÁnChez \\ Álvaro Moreno Duran ${ }^{* * * *}$
}

\section{INTRODUCCIÓN}

El derecho administrativo colombiano experimenta una importante transformación: Diversas decisiones del Consejo de Estado, dan muestra de una actitud garantista de los derechos acorde con los avances y procesos de transformación de la sociedad colombiana. Así, por citar algunos ejemplos recientemente se determinó que en los eventos de reparación integral a las víctimas de la violencia, el principio de progresividad hace posible que las autoridades judiciales amplien de manera gradual la reparación, si el agravio no cesa, sino que produce reiteradamente, de manera que la indemnización de perjuicios no necesariamente debe presentarse en un único pago, sino que la misma puede suceder en forma gradual según la evolución del perjuicio sufrido (Exp. 21884, 2012); de otra parte, se ha superado el tope indemnizatorio de los perjuicios morales en escenarios en los que el daño antijurídico imputable al Estado tiene su origen en una conducta punible (Exp. 36340, 2013a) y; se ha efectuado el reconocimiento de derechos a seres vivos distintos del ser humano en cuyo caso cualquier persona puede solicitar su protección por conducto de la acción popular (AP 25000232400020110022701, 2013b).

* El capítulo del libro es producto del proyecto de investigación institucional titulado: "Derecho Procesal", el cual hace parte de los proyectos de investigación institucionales de la Universidad Santo Tomas.

** Magister en Derecho Público - Universidad Santo Tomás en Convenio con la Universidad de Konstanz. Docente e investigador de la facultad de Derecho de la Universidad Santo Tomas. Correo Electrónico: diegomorales164@gmail.com

*** Doctor en Sociología - Universidad de París. Docente e investigador de la Universidad Santo Tomas. Correo Electrónico: alvaromoreno@usantotomas.edu.co 
De otra parte, la entrada en vigencia del Código de Procedimiento Administrativo y de lo Contencioso Administrativo-CPACA-, expedido mediante la ley 1437 de 2.011 apunta a la modernización de los procedimientos administrativos y de la Jurisdicción Contencioso-Administrativa, en mérito de lo cual se adoptan estrategias encaminadas a la implementación de la oralidad y el uso de las tecnologías de la información y las comunicaciones con el fin de reducir significativamente el impacto de fenómenos que, como sucede con la congestión judicial, afectan la solución de las controversias cuyo conocimiento compete a ésta jurisdicción.

En ese contexto, llama la atención el recurso extraordinario de unificación contencioso-administrativo, contemplado en los artículos 270 y 271 del CPACA, puesto que con su consagración se introduce una figura que, pese a no ser novedosa si se compara con la actividad de la Corte Constitucional, se destaca su propósito de superar el tradicional motivo de unificación denominado importancia jurídica e incluir la trascendencia social y económica junto a la necesidad de sentar o unificar la jurisprudencia y de aquellas decisiones proferidas en desarrollo del mecanismo eventual de revisión -aplicable en los eventos de acciones populares y de grupo-, así como de aquellas decisiones relacionadas con los recursos extraordinarios.

De implementarse satisfactoriamente, un mecanismo judicial como el descrito, contribuiría a la reducción de la complejidad dentro de la Jurisdicción Contencioso-administrativa si se tiene en cuenta que, con fundamento en los artículos 10, 102 y 269 CPACA, los efectos de la sentencias de unificación deben reconocerse por las autoridades administrativas cuando los solicitantes acrediten los mismos supuestos fácticos y jurídicos que dieron lugar a la sentencia de unificación. Corolario de lo cual, los principios de seguridad jurídica y justicia material se realizarían a través de la interpretación y aplicación uniforme del derecho.

B. Metodología y estructura

1. Delimitación de la investigación

Resulta necesario demarcar la situación que se pretende indagar puesto que, como se dijo, la unificación jurisprudencial contencioso-administrativa 
es relativamente reciente tomando como punto de partida la expedición del CPACA, de suerte que la delimitación del mismo concepto carece de fuentes jurisprudenciales tomando como punto de partida la fecha de entrada en vigencia del mencionado estatuto -2 de julio de $2012-$.

En vista de las dificultades que reviste el problema de investigación y dada la escasez de fuentes que ambientan una delimitación, surge la necesidad de emplear un lenguaje que guarde relación entre el contenido de las disposiciones sobre unificación administrativa y, en ese orden, permita diseñar un esquema que brinde pautas para la práctica de la unificación jurisprudencial contencioso-administrativa.

Ésta propuesta no se circunscribe exclusivamente al estudio del derecho administrativo, así como tampoco se aborda desde prácticas foráneas referentes al precedente administrativo; por el contrario, se pretende diseñar, explicar y poner a prueba una alternativa metodológica de unificación jurisprudencial cuyo referente, en sentido estricto, no se encuentra al interior del ordenamiento jurídico.

Del mismo modo, no se ahondará en las implicaciones teóricas de los postulados presentados en ésta investigación toda vez que su propósito está encaminado a la esquematización de una estructura que permita reducir la complejidad en sede de unificación jurisprudencial; sin embargo, los enunciados que se consignan tienen su razón de ser en tanto contribuyen a la estructuración propuesta, de manera que desde el punto de vista lógico y metodológico, tengan el suficiente fundamento que permita su implementación. Ello atendiendo a que "los únicos fines intelectualmente importantes son: la formulación de problemas; la propuesta tentativa de teorías para resolverlos; y la discusión crítica de las teorías en competición" (Popper, 2002, p. 30).

\section{Estructura del trabajo}

En su primera parte, la investigación se desarrolla a partir de los conceptos de complejidad y riesgo, propios de la sociología y con injerencia directa en el campo jurídico. Estas categorías fungen a su vez como continentes de subcategorías que evidencian la existencia de fenómenos que, hallándose entrelazados, inciden en las decisiones judiciales en formas variadas. 
Así, partiendo del concepto de neoconstitucionalismo, entendido éste como la doctrina garantista de los derechos fundamentales, puede afirmarse que constituye el marco dogmático que regula la actividad de los poderes públicos $\mathrm{y}$, por tanto impregna e informa la tarea de unificación jurisprudencial de conformidad con lo prescrito en la Constitución Política de 1991. En igual sentido, se entrelaza el componente propio de las sociedades del Siglo XXI denominado Globalización, toda vez que a partir de dicho proceso, las teorías jurídicas, económicas y doctrinas políticas de otros estados han interactuado y enriquecido, de la misma forma en que unas corrientes dominantes se han impuesto frente a otras o; simplemente, estados que, encontrándose en la búsqueda de soluciones a sus problemas, han empleado mecanismos de mimetización y trasplante de instituciones y doctrinas foráneas, creando establecimientos autónomos desde el punto de vista local pero heterotópicos en la perspectiva global.

En consonancia con lo señalado, se tiene que fenómenos como la diversidad o heterogeneidad de la sociedad colombiana resultan reflejados en la asunción de decisiones a través de sus jueces, de suerte que la complejidad de la situación materia de estudio se incrementa, requiriendo, como es preciso, la interrelación de otros elementos que permitan reducir aquella complejidad a través de procedimientos como la codificación y la asignación de competencias en el campo jurídico; sin embargo, este propósito lleva implícito el riesgo de que pudiera no ser útil ni idóneo el proceso de codificación dado que el Derecho resulta siendo aquello que los jueces dicen y no aquello que las normas señalan pese a ser un país cuya tradición jurídica se enmarca en el respeto al principio de legalidad.

Se plantea la necesidad de ahondar la cuestión referida a la complejidad y el riesgo bajo una óptica con mayor capacidad de abarcamiento y simplificación que, a su vez, reconozca una diversidad de elementos con injerencia directa en la práctica judicial y no actúe de manera mutilante frente a la diversidad de contextos y significados posibles en la interpretación y aplicación de las normas jurídicas.

Posteriormente, el capítulo segundo plantea, a la manera de una revisión corporativista, la situación existente entre los recursos extraordinarios de casación contencioso-administrativa del derecho español y costarricense, en contraste con el recurso extraordinario de unificación de jurisprudencia previsto en la Ley 1437 de 2011 delimitando su naturaleza, efectos y alcances individuales, haciendo especial énfasis en la situación del recurso extraordinario local. 
Por su parte, el capítulo tercero propone una metodología descriptiva de la relación entre los conceptos, la atribución de su significado, la estructuración de la decisión judicial y el efecto de la misma en el tiempo. Podría indicarse que dicho capítulo parte desde su conclusión toda vez que principia desde la propuesta de solución al problema de la investigación y, a partir de su exposición se desarrollan los distintos elementos que componen ésta propuesta metodológica.

En este aspecto, se toma como punto de partida la formas de similitud ampliamente descritas por Foucault en su obra "Las palabras y las cosas" (2010) sin perder de vista la pertinencia de sus afirmaciones en el Derecho, para lo cual, se propone la interacción de sus ideas con una obra que constituye pieza obligatoria en el proceso académico de formación y comprensión del escenario jurídico: "El concepto de Derecho" de Herbert Hart (1998), cuyas afirmaciones coinciden e incluso llegan a asimilarse frente a las descripciones de la obra foucaultiana en punto del lenguaje, los conceptos y su significado.

De allí, con miras al diseño de una estructura del precedente contenciosoadministrativo, se examinarán los componentes dentro de los cuales la atribución de significado de los conceptos tiende a la estabilización del sentido de las decisiones judiciales, a la comprobación práctica de las circunstancias jurídicas o al logro de una mayor claridad y precisión de los conceptos del derecho en sede jurisdiccional de suerte que, a partir de la determinación preestablecida sea menester precisar el alcance que la decisión judicial tendrá en el ordenamiento y la praxis jurídica en aras de iniciar procesos de asentamiento de posiciones jurídicas, a fin de que éstas con el permanente ejercicio de la actividad judicial resulten consolidadas $\mathrm{y}$, en el desarrollo continuo de la práctica judicial, sea posible unificar las decisiones del Consejo de Estado como supremo órgano de la Jurisdicción de lo Contencioso-administrativo.

Por último, el cuarto capítulo pretende someter a juicio de falseabilidad la hipótesis planteada en la presente investigación, de manera que pueda establecerse la pertinencia del modelo propuesto de unificación y su capacidad de reducir la complejidad existente en el tratamiento que la jurisdicción de lo Contencioso-Administrativo le ha dado al tema de la privación injusta de la libertad. 


\section{CAPÍTULO I \\ SOCIEDAD Y PRÁCTICAS JURÍDICAS}

La Constitución Política de 1991 ha introducido fuertes cambios en la manera en que tanto ciudadanos como jueces ven y comprenden el derecho, así como la forma en que aquellos perciben a los operadores jurídicos. Sumado a lo anterior, las políticas estatales han priorizado procesos enmarcados dentro de la dinámica de la globalización cuyo propósito es el fortalecimiento de las relaciones económicas, comerciales e institucionales con otros estados y organismos multilaterales, de allí que se "ha reducido la sensación de aislamiento experimentada en buena parte del mundo en desarrollo y ha brindado a muchas personas de esas naciones acceso a un conocimiento que hace un siglo ni siquiera estaba al alcance de los más ricos del planeta" (Stiglitz, 2004, p. 28).

En este contexto, es necesario que la respuesta de la actividad judicial se encuentre no sólo en sincronía con el caso concreto, sino que además aquella solución individualmente considerada debe comprenderse y dimensionarse en el contexto global. Es decir, se requiere que el fallo provea y evidencie unos mínimos parámetros de estabilidad, en donde el interés de organismos multilaterales, inversionistas y políticas transnacionales no se encuentren condicionadas a las continuas fluctuaciones y excesos de la jurisprudencia local (Botero, 2014). Puesto que de perpetuarse o mantenerse incólume esta situación, la pretensión de controlar los riesgos o de cuantificar sus resultados a través de elementos que transmitan e implementen mecanismos encauzados hacia la certidumbre y seguridad (Beck, 2002, p. 2), corren el riesgo de colapsar ante el arbitrio de los funcionarios judiciales.

Bajo éste entendido, la complejidad del mundo jurídico implica el reconocimiento de las heterotopías en que la sociedad se desenvuelve puesto que, como describe Foucault (2010):

[M]inan secretamente el lenguaje, porque impiden nombrar esto y aquello, porque rompen los nombres comunes o los enmarañan, porque arruinan de antemano la "sintaxis" y no sólo la que construye las frases aquella menos evidente que hace "mantenerse juntas" (unas al otro lado o frente de otras) a las palabras y a las cosas. (p. 11).

Ese entorno social heterogéneo permite el desarrollo de relaciones jurídicas, las cuales tienden a interpretar los fenómenos sociales y dilucidar las situaciones que en dicho entramado se presentan, de modo que las 
diversas manifestaciones de la sociedad hallan en el ordenamiento jurídico y sus operadores una explicación - o respuesta- aparentemente exitosa de aquellas, lo cual pone de presente la existencia de posiciones diversas en torno a la naturaleza de lo real y la naturaleza del conocimiento (Morin, 2007, p. 65) y es justo allí donde se corre el riesgo que muchas investigaciones académicas terminen inexorablemente archivadas en los anaqueles de las universidades dado que corresponden a proyecciones metafísicas que de ninguna manera interpretan la realidad.

Incluso, como anota Morin (2007, p. 79) "la ciencia se ha vuelto ciega por su incapacidad de controlar, prever, incluso concebir su rol social, por incapacidad de integrar, articular, reflexionar sus propios conocimientos". Así pues, resulta necesario adscribir un componente teórico a aquella(s) situación(es) que en la realidad social demanda una explicación o una solución.

En este orden de ideas, la Constitución Política de 1991 y los aportes a la doctrina del neoconstitucionalismo demarcan el contexto de uniformidad y estabilidad del ordenamiento jurídico y por tanto, de la decisión judicial. Sin embargo, como se verá posteriormente, las reflexiones esbozadas por los teóricos de ésta doctrina en aspectos tales como la ponderación, los tests, las reglas y problemas teóricos específicos del neoconstitucionalismo, no serán materia de ésta investigación puesto que lo que se pretende es la ambientación de una propuesta de unificación jurisprudencial, la cual se expondrá en líneas posteriores.

A.

\section{LA INTERPRETACIÓN DEL TEXTO CONSTITUCIONAL}

La ruptura del tradicional enfoque orgánico-constitucional trajo consigo la adopción de textos constitucionales dotados de fuerza material y normativa más allá de las meras distribuciones de competencias y asignación de poderes de los órganos estatales. En tal sentido, los modernos diseños constitucionales contienen significativos niveles de normas sustantivas en virtud de las cuales se orienta la actividad del Estado y sus órganos. Aunado a ello, las prácticas de los tribunales constitucionales evidencian un viraje conceptual hacia posturas e interpretaciones garantistas $\mathrm{y}$, por tanto, compatibles con los textos de las nuevas constituciones nacionales, de suerte que la hermenéutica jurídica debe involucrar elementos meta y extrajurídicos a fin de sincronizarse con la sociedad y sus cambiantes prácticas.

Como consecuencia de lo anterior, se encuentra que la Constitución representa el punto de partida para la actividad de los tribunales, operadores 
jurídicos y la sociedad, de allí que "El término Constitución es usado en el lenguaje jurídico (y político) con una multiplicidad de significados (cada uno de los cuales presenta muy diversos matices)" (Guastini, 2007, p. 15).

En igual sentido, "aquello que llamamos constitución consiste precisamente en este sistema de reglas, sustanciales y formales, que tiene como destinatarios propios a los titulares del poder" (Ferrajoli, 2008, p. 33), dicha postura se dilucida desde una doble óptica: en primer lugar, imponiéndole de manera negativa al poder público restricciones intangibles sobre los derechos humanos y; en segundo lugar, señalando que los actos ilícitos y las violaciones de derechos subjetivos serán sancionados o anulados (Ferrajoli, p. 64).

La Constitución determina el eje transversal y común a todas las decisiones jurídicas comoquiera su efecto de irradiación no sólo resulta tangible en las decisiones de los jueces, sino también en las mismas reglas del ordenamiento jurídico en donde se presentan diversas acepciones respecto de un mismo fenómeno, esto es, "la común aceptación de conceptos, la intercambiabilidad de argumentaciones jurídicas (validas, de la misma manera, e incluso en unas y otras jurisdicciones nacionales)" (Guastini, 2007, p. 39)

No obstante, la práctica jurisprudencial ha puesto en evidencia que los cambios de los usos y/o de las costumbres de la sociedad no encuentran respuestas jurídicas satisfactorias si se considera que las mismas residen al interior del ordenamiento. Evento que puede explicarse teniendo en cuenta las implicaciones de la globalización en tanto "proceso (...) que crea vínculos y espacios sociales transnacionales, revaloriza culturas locales y trae a un primer plano terceras culturas - «un poco de esto, otro poco de eso, tal es la manera como las novedades llegan al mundo»" (Beck, 1998, p. 36) ello sumado al hecho que "las personas que participan en el sistema jurídico actúan como maximizadores racionales de sus deseos" (Posner, 2011, p. 83). De allí que sean los jueces los encargados de actualizar las premisas jurídicas interpretándolas de manera consonante con las transformaciones sociales.

Éste proceso de actualización del ordenamiento jurídico se escinde en dos momentos: el de la interpretación de la norma y la aplicación de la misma atendiendo su propio lenguaje. La actividad interpretativa, "es en cierto sentido una recreación, pero ésta no se guía por un actor creador precedente sino por la figura de la obra ya creada, que cada cual debe representar del modo como él encuentra en ella algún sentido" (Gadamer, 2007c, p. 165). Entonces, no se pretende ir más allá de la obra del constituyente, sino que se parte de su proposición normativa con miras a desentrañar el contenido 
de la norma jurídica "en su tránsito de una grada superior a una inferior" (Kelsen, 1998, p. 349).

La atribución de significado de las disposiciones constitucionales implica el reconocimiento de las diversos sentidos que el concepto de interpretación constitucional adquiere; así por ejemplo, la actividad hermenéutica puede referirse a la Constitución como un orden producto de la manifestación popular en donde la interpetación dista de la asignación de un significado a un documento para trasladarse a la adjunción de un sentido a un objeto naturalcultural. (Comanducci, p. 54); de otra parte, se trata de una labor adjudicada a los jueces, correspondiéndole a tales autoridades la determinación de su contenido a través de ejercicios propios de la actividad de la judicatura.

Con todo, la interpretación de la Constitución implica la adscripción de un contenido mucho mayor al que se desprende de la mera hermenéutica de la ley, de manera que los resultados de ese ejercicio debe prescribir aquellas interpretaciones razonables del texto constitucional, sujetando desde tales lineamientos la actividad política del legislador y los demás poderes públicos (Ibíd, p. 58). Aquí resulta notoria la jerarquía y el posicionamiento político de los jueces constitucionales respecto de los demás jueces puesto que, mientras que la función de éstos se limita al reconocimiento de los derechos contenidos en las normas legales; la función de aquellos tiende a la creación del Derecho, no de manera libre pero tampoco sujeta a importantes restricciones. (Ibíd. p. 59). Bajo este supuesto, tiene cabida el empleo de elementos extra y metajurídicos en los que se manifiestan los influjos de las corrientes de pensamiento en áreas tan diversas como la sociología, la filosofía siempre teniendo "conciencia de la historicidad de todo presente y de la relatividad de todas las opinones" (Gadamer, 2007a, p. 41).

\section{LA FUNCIÓN GARANTISTA}

Ante todo, el ejercicio de la actividad judicial, implica fundamentalmente la garantía de los derechos e intereses amparados en los textos constitucionales. De suerte que la intervención de las autoridades judiciales se encuentra dirigida a "afianzar, asegurar, proteger, defender, tutelar algo, y cuando en la cultura jurídica se habla de garantismo, ese algo que se tutela son derechos o bienes individuales" (Gascón, 2005, p. 21).

En este ámbito, tiene cabida la doctrina denominada garantismo, sobre la cual vale la pena anotar que preliminarmente se enfocó en el aspecto procesal del ordenamiento jurídico-penal, puesto que se trata de una 
"técnica de minimización de la violencia reactiva de las instituciones de ese ámbito" (Ibáñez, 2005, p. 61). Asimismo, llama la atención el hecho que ésta doctrina hace referencia a una propuesta metodológica que separa el ser de la norma junto con el deber ser y "atribuye a la teoría del derecho una función de análisis y crítica de la deslegitimización de las instituciones jurídicas positivas" (Gascón, p. 23).

Siguiendo las ideas precedentes, la función del juez no se limita a la interpretación de la norma jurídica, sino que además debe encontrar aquella comprensión acorde con los principios y valores contenidos en la Constitución y el Estado Social y Democrático de Derecho, de manera que los derechos individuales fundan la estructura garantista, en donde las instituciones políticas y jurídicas "se justifican no sólo como males necesarios sino también como instrumentos al servicio de aquellos derechos" (Gascón, p. 24). Bajo la anterior dinámica, el contenido de las constituciones se actualiza en tanto muestra coherencia con las cambiantes prácticas sociales y, en tal medida, el andamiaje estatal se determina de acuerdo con tales variaciones.

Ahora bien, el esquema garantista implica la fijación en un juez con autonomía en sus decisiones, es decir, "una fuerte demanda de imparcialidad judicial, entendida en el sentido más exigente y, a su vez, con una doble y rigurosa proyección. En efecto, el juez está obligado a ser intérprete crítico, en clave constitucional“" (Ibáñez, p. 65); sin embargo, con el fin de lograr tales garantías, el juez debe tener una sapiencia que le ha de servir incluso en la subsunción comoquiera que buscará la "verdad jurídica en cuanto es comprobable a través de la interpretación, del significado de los enunciados normativos" (Ibáñez, p. 66), puesto que si el juez pretende garantizar derechos en contra de la arbitrariedad, no debe con su conducta obrar de manera que resulte arbitraria (Gascón, p. 27) sino motivado siempre por el esquema garantista que le permita obtener una comprensión más coherente que aquella previsión contenida en la norma.

Así las cosas, la tarea del juez consistirá en auto-referenciarse para determinar qué tanto ha sido entendido, en otras palabras "a la tarea del escritor, corresponde aquí la tarea del lector, destinatario o intérprete de lograr esa comprensión, es decir, de hacer hablar de nuevo al texto fijado" (Gadamer, 2007c, p. 332).

Por este camino, pueden presentarse tres alternativas en la esencia de lo fallado: 1) observar con atención a qué grado estaba la norma de ser 
interpretada, esto es, si se manifestó aquella previsión del legislador frente a la respuesta del caso; 2) si la decisión puede cumplirse en el sentido fijado, toda vez que la relevancia de la solución amerita la comprensión de su y; 3) si el texto normativo consultado resulto idóneo para la solución del caso o si por el contrario, fue necesario actuar en forma decisionista, de manera que el texto prefijado ubicó al operador jurídico en un plano de apertura a la creación del derecho.

\section{CAPÍTULO II}

\section{LA UNIFICACIÓN DE JURISPRUDENCIA CONTENCIOSO-ADMINISTRATIVA: UN ACERCAMIENTO IUSCOMPARATIVISTA}

Tal y como lo evidencia el contenido, alcance y efectos previstos para el recurso extraordinario de unificación de jurisprudencia, es claro que el mismo no obedece a un proceso de creación auténtico del derecho local puesto que dicho mecanismo jurídico emula, con sus variaciones, el mecanismo procesal existente en los ordenamientos español y costarricense referente a la casación contencioso-administrativa.

De manera que, aun cuando se persigue la unidad de la interpretación y aplicación del derecho, se corre el riesgo de adoptar un producto jurídico cuyos resultados pudieran no ser satisfactorios o bien, no ajustarse a los cánones interpretativos y contextuales en que dicho instituto tuvo origen.

Podría considerarse que ante las necesidades sociales o académicas de los entornos de producción, el efecto unificador y correctivo de la casación sea adecuado frente a las necesidades planteadas; mientras que en ordenamientos ajenos al de orígen, la adopción de éste desarrollo jurídico, presenta una doble contingencia: 1) La existencia de una respuesta equivocada al problema planteado o; 2) El incremento de la complejidad en la resolución del asunto planteado puesto que las condiciones en que surge y se desarrolla el problema no son las mismas del entorno de creación. (López, p. 67).

\section{A. ESPAÑA}

La práctica judicial contencioso-administrativa española tiene como referente la Ley 29/1998 - Ley reguladora de la Jurisdicción Contenciosoadministrativa -en adelante, LJCA- la cual consagra, desde perspectivas 
distintas, instituciones jurídicas paradigmáticas que nutren los sistemas de derecho Contencioso-Administrativo costarricense y colombiano: Por un lado, la posibilidad de extender los efectos de las decisiones judiciales en determinados ámbitos y; de otra parte, se encuentra el Recurso Extraordinario de Casación Contencioso-administrativa y sus diversas modalidades, entre ellas, la de Casación para la unificación de doctrina.

El artículo 110 LJCA prescribe la posibilidad de extender los efectos de una sentencia firme que hubiera reconocido una situación jurídica individualizada a favor de una o varias personas siempre que la controversia ventilada hubiese recaído en las áreas tributaria, de personal al servicio de la Administración pública y de unidad de mercado. Éste elemento constituye una diferencia fundamental frente a los mecanismos de extensión de jurisprudencia costarricense y colombiano puesto que su ámbito de aplicación no se encuentra delimitado en las normas jurídico-procesales que los consagran. Con todo, no se ahondará en éste punto en razón a que no concuerda con los propósitos de la investigación.

El recurso extraordinario de casación Contencioso-Administrativo pretende la depuración y rectificación interpretativa del ordenamiento jurídico al amparo de causales específicas (Ruíz, 2012) tal y como acontece con el recurso homónimo propio de la jurisdicción ordinaria colombiana. En éste sentido, el Tribunal Supremo ha delimitado el recurso de casación precisando que:

Ese carácter extraordinario supone la exigencia de que se efectúe una crítica de la sentencia o resolución objeto del recurso, mediante la precisión de las infracciones que se hayan cometido, con indicación concreta de la norma en que se base el recurrente, sin que sea posible, para entender que se cometen las infracciones que se denuncian, con la simple remisión a los escritos de alegaciones o reproducción de las formuladas en la instancia, en cuanto que lo que se impugna es la sentencia y no los actos o disposiciones sobre los que aquella se pronunció y que fueron por ella confirmados o anulados. (STS 7222/2005).

La LJCA prevé tres modalidades distintas que puede asumir el recurso extraordinario de casación: el recurso de casación stricto sensu; el recurso de casación para la unificación de doctrina y el recurso de casación en interés de la ley.

No obstante lo anterior, para los fines de la presente investigación sólo se hará especial mención de los recursos de casación para la unificación de 
doctrina y aquel en interés de la ley, siendo éstos los que, por sus efectos, coinciden con el alcance de la denominada sentencia de unificación contencioso-administrativa del derecho colombiano.

Respecto de la casación para la unificación de doctrina (Arts. 96-99 LJCA), se encuentra que su propósito coincide con la garantía de igualdad en la aplicación e interpretación de la ley en tanto apunta a la unificación de posturas judiciales contradictorias. A fin de que se simplifique la diversidad de criterios posibles a través del asentamiento o reconocimiento de la doctrina judicial correcta, en palabras del Tribunal Supremo:

[L]a contradicción entre las sentencias ha de ser ontológica, esto es, derivada de dos proposiciones que, al propio tiempo, no pueden ser verdaderas o correctas jurídicamente hablando y falsas o contrarias a derecho, situación que ninguna analogía presenta con la de sentencias distintas o diferentes, pese a la identidad de planteamientos normativos y de hecho, por el, a su vez, distinto resultado probatorio o por la también distinta naturaleza que pudiera predicarse respecto de los supuestos planteados. (STS 309/2004).

De igual manera, se encuentra el recurso de casación en interés de la ley (Arts. 100 y 101 LJCA), en virtud del cual el enjuiciamiento de la decisión judicial apunta a la corrección en un doble sentido: el de la doctrina expuesta y el de la interpretación de la norma jurídica aplicada sin afectar, en todo caso, los derechos que se hubiesen adquirido al amparo de la sentencia recurrida. Así, en este caso, es presupuesto la existencia de una doctrina, que aparte de errónea, constituye grave afrenta para el interés general os son, pues, los requisitos exigidos: que se trate de una doctrina errónea y, adicionalmente lesiva para el interés general. De tal suerte que la doctrina o fundamentación de la resolución impugnada, que se considera gravemente dañosa y errónea, no se aplique, de ser declarada como tal, a situaciones similares a las enjuiciadas por aquélla. (STC 37/2012)

De acuerdo con lo anterior, la vocación unificadora de la decisión judicial producto de las sentencias de casación para la unificación de doctrina y en interés de la ley, tienen como efecto directo la invalidación de la decisión judicial que controvierte una posición previa y consolidada sobre un punto de derecho.

Sin embargo, el propósito de la sentencia de unificación dentro de la práctica judicial colombiana no muestra un resultado similar al que se produce en el derecho español, puesto que el proferimiento o identificación de una sentencia unificadora, a pesar de sentar una posición jurídica 
sustitutiva respecto de decisiones judiciales previas, rectifica las doctrinas preexistentes mas no las invalida ni las priva de efectos en derecho, por lo que resulta latente el escenario de inseguridad jurídica en tanto subsisten posiciones contradictorias.

B. COSTA RICA

La entrada en vigencia de la Ley No. 8508 - Código Procesal Contencioso Administrativo - en adelante, CPCA - ha dado lugar a la implementación del mecanismo denominado Proceso de extensión y adaptación de la jurisprudencia a terceros, descrito en el Capítulo I del Título IX de la mencionada Ley.

En virtud del proceso señalado, y de acuerdo a lo previsto en el artículo 185 CPCA los efectos de la jurisprudencia contenida al menos en dos fallos de casación, ya sean del Tribunal o de la Sala Primera de la Corte Suprema de Justicia, que haya reconocido una situación jurídica, podrán extenderse y adaptarse a otras personas, siempre que, en lo pretendido exista igualdad de objeto y causa con lo ya fallado. Así pues, de la misma forma en que sucede en el derecho colombiano, por cuanto se exigen una decisión judicial previa objeto de extensión -sentencia de unificación-, en el derecho contenciosoadministrativo costarricense constituye presupuesto ineludible la existencia de dos sentencias de casación.

El recurso extraordinario de casación, en el ordenamiento ContenciosoAdministrativo costarricense, desarrolla una función dual: Por un lado, se le encomienda la protección del ordenamiento jurídico y; de igual forma, tiene un rol uniformador de la jurisprudencia contenciosa en razón a que "la permanencia existencial del interés público, las prerrogativas de la Administración y los derechos del administrado trascienden el contenido puro de las normas jurídicas" (González \& Hiness, 2006, p. 18).

En tal sentido, la Sala Primera de la Corte Suprema de Justicia de Costa Rica ha estimado:

[L]a casación se concede sólo respecto de ciertas resoluciones definitivas dictadas en juicios de trascendencia, en procura de la correcta y uniforme aplicación o interpretación de la ley, y de evitar la introducción de prácticas viciadas y abusivas en el trámite de los juicios (...) no es su fin primario, remediar fallos injustos, pues se da para resguardar la legalidad, mantener la uniformidad de 
la jurisprudencia, así como la estabilidad y el rigor de los procedimientos en la tramitación de un proceso. (Sentencia No. 00031, 1994).

Con todo, la casación en éste punto no se torna sustitutiva de la interpretación auténtica de la ley, encontrándose que tiende a fungir como mecanismo de unificación de los modelos de comportamiento frente a los sentimientos sociales que el ordenamiento jurídico ha consagrado o elevado a la condición de valores. (González \& Hines, p. 22).

Dentro de las características individuales del recurso en mención, aparecen las causales encaminadas a la protección del ordenamiento jurídico bajo tres situaciones: 1) La casación por razones procesales (art. 137 CPCA); 2) la casación por violación de las normas sustantivas del ordenamiento jurídico (art. 138 CPCA) y; 3) la casación en interés del ordenamiento jurídico (art. 153 CPCA). De lo anterior, se infieren sendos resultados jurídicos distintos a saber:

1) Atendiendo la prescripción del artículo 150.1 CPCA, cuando se encuentre acreditada la infracción de normas procesales, se dispondrá la nulidad del proceso hasta la etapa en que la trasgresión procesal tuvo lugar y se remitirá el proceso al Tribunal de origen a fin de que rehaga las actuaciones viciadas $y$, si se trata de la sentencia, en tanto acto procesal, se dispondrá su anulación a fin de que el a quo emita la decisión pertinente. Como se observa, el efecto de la decisión casacional se asemeja al de una apelación motivada por errores in procedendo de la sede judicial antecedente, al punto que la actuación remedial le compete al órgano judicial instructor de la controversia adelantada y no al Juez de casación.

2) Si la sentencia se casa por infracción de normas sustanciales, el artículo 150.2 CPCA prevé que en la resolución que acuse la ocurrencia de las causales invocadas (art. 138 CPCA) se falle el proceso. Éste efecto de la decisión casacional resulta compatible con el que se manifiesta en la práctica de la jurisdicción ordinaria colombiana, puesto que el éxito del recurso compele al Juez de casación al proferimiento de una sentencia sustitutiva.

3) La casación en interés del ordenamiento jurídico (art. 153 CPCA) tiene lugar cuando la sentencia, no habiendo sido conocidas por la Sala Primera, se estime violatoria del ordenamiento jurídico. En cuyo caso, deberán fijarse la correcta interpretación y aplicación del ordenamiento sin afectar las situaciones jurídicas derivadas de la sentencia recurrida ni afectar aquellas situaciones consolidadas al amparo de la doctrina errónea. 
Como se observa, el antecedente del mecanismo de extensión de jurisprudencia, es decir, la sentencia de casación, se depura a través de formas procesales rigurosas en virtud de las cuales la práctica judicial ha determinado inexorablemente las situaciones dentro de las cuales se abre paso la extensión de los efectos de las decisiones judiciales, de suerte que aquellas controversias carentes del mínimo plural de sentencias de casación sobre un mismo punto de derecho gozan de un tratamiento sui generis dada la ausencia de doctrina judicial sobre la materia.

\section{COLOMBIA}

La promulgación de la Ley 1437 de $2011^{102}$ y su situación de vigencia diferida permitió la divulgación y ambientación del nuevo estatuto procesal. Con tal propósito, las temáticas referentes a la unificación de la jurisprudencia administrativa y el mecanismo de extensión de jurisprudencia fueron encauzados hacia la conceptualización y precisión de sus contenidos y alcances. En lo particular, Hernández Becerra (2011, p. 235) afirma:

La ley 1437 de 2011 propone, en cinco artículos (10, 102, 269, 270 y 271), un práctico sistema de reglas que convierte a la jurisprudencia en guía segura para que el Estado dé a los ciudadanos un trato más igualitario y justo. Dicho sistema tiene como eje una especial categoría de sentencia, la Sentencia de Unificación Jurisprudencial definida en el artículo 270 del nuevo código y que, bajo determinadas condiciones y según procedimientos especiales, competerá expedir al Consejo de Estado, en su condición de "tribunal supremo de lo contencioso administrativo", según las voces del artículo 237 numeral 1 de la Constitución.

De acuerdo con lo anterior, la categoría de sentencia de unificación, en virtud de lo prescrito por el artículo 270 del CPACA, corresponderá a aquella decisión judicial proferida en los eventos de: 1) Por importancia jurídica; 2) Por trascendencia económica o social; 3 ) Por necesidad de unificar o sentar jurisprudencia; 4) Por la decisión de recursos extraordinarios (de revisión y de unificación jurisprudencial y; 5) Las relativas al mecanismo eventual de revisión de las decisiones proferidas dentro de Acciones Populares o de Grupo $^{103}$. Correspondiéndole al órgano de cierre de la Jurisdicción de lo

\footnotetext{
$102 \quad 18$ de enero de 2011.

103 Hoy, medios de control denominados "Protección de los derechos e intereses colectivos" (Art. 144 CPACA) y "Reparación de los perjuicios causados a un grupo" (Art. 145 Ibídem), respectivamente.
} 
Contencioso Administrativo la determinación de los contenidos jurídicos materia de unificación. De lo cual se desprende que la categoría de sentencia de unificación obedece al cumplimiento de exigencias eminentemente formales a la manera de una lista de comprobación, resultando excluidas aquellas que no se adecuan a ninguno de las condiciones prefijadas en el artículo 270 CPACA.

Al respecto, el recurso extraordinario de unificación de jurisprudencia (art. 256 CPACA) tiene como finalidad aquella semejante a la del recurso de casación para la unificación de la doctrina y en interés de la ley del derecho español (arts. 96-101 LJCA), en consonancia con el de casación por infracción de normas sustanciales y en interés del ordenamiento jurídico del ordenamiento costarricense (arts. 138 y $153 \mathrm{CPCA}$ ) puesto que se encamina hacia la unidad de la interpretación del derecho, su aplicación uniforme, la garantía de los derechos de las partes y de los terceros que resulten perjudicados con la providencia recurrida y, de ser necesario, reparar los agravios inferidos a tales sujetos procesales.

Contrario a lo que acontece en los ordenamientos español y costarricense, el recurso extraordinario de unificación de jurisprudencia sólo prevé una causal, siendo esta la contravención u oposición de una sentencia de unificación del Consejo de Estado proferida por los Tribunales Administrativos en segunda o única instancia (art. 258 CPACA). Sin embargo, llama la atención el efecto que produce la decisión judicial corolario del recurso extraordinario, puesto que, a pesar de no encontrarse tasado bajo precisas causales en donde la garantía del derecho sustancial puede sacrificarse ante la liturgia de las formas procesales, es notoria su tendencia pro actione al punto que la decisión judicial impugnada padece los efectos de una sentencia casacional, puesto que ésta se torna nula y sustituida por la providencia decisoria del recurso.

Por otro lado, en concordancia con el artículo 259 CPACA, el Consejo de Estado ha dispuesto la reconformación funcional de las secciones que componen la Sala de lo Contencioso-administrativo. Así, mediante el Acuerdo No. 148 de 2014 reformatorio del Acuerdo 58 de 1999 -Reglamento del Consejo de Estado- se dispuso en su artículo 1 que las mencionadas secciones podrán, en el marco de su especialidad, tramitar y decidir el recurso extraordinario de unificación de jurisprudencia y dictar las sentencias de unificación jurisprudencial por razones de importancia jurídica, trascendencia económica o social o necesidad de sentar jurisprudencia, en relación con los asuntos que provengan de las Subsecciones o de los Tribunales Administrativos. 
No obstante, la norma en cita sólo se encauza hacia la asignación puntual de funciones, dejando al arbitrio de los consejeros de estado la gestación del fallo de unificación. En este punto es necesario recordar que la función de la sentencia de unificación tiende a contribuir a la eficacia del mecanismo de extensión de jurisprudencia, resultado de lo cual se aminoraría la litigiosidad contencioso-administrativa en función del reconocimiento de casos iguales posteriores sujetos a la eventual aplicación de una misma sentencia de unificación jurisprudencial por vía de extensión.

Por tanto, el reconocimiento del fallo de unificación debe identificar aquella causa petendi común y proveer sobre ésta una solución razonable y equivalente, de manera que la función judicial satisfaga la pretensión de mayor abarcamiento de casos posibles bajo idénticos razonamientos jurídicos. Puesto que, como sostiene Rojas Betancourth (2012):

[E]l caso igual impone al Consejo de Estado un gran rigor en la elaboración de las sentencias de unificación, para evitar mensajes hermenéuticos ambiguos que hagan no solo difícil la extensión de la jurisprudencia, sino también para evitar que en sede judicial la propia Corporación se vea en la obligación permanente de hacer precisiones o rectificaciones evitables.

En aras del propósito unificador, el Gobierno Nacional y la Rama Judicial han emprendido esfuerzos significativos en la tarea de contribuir a la reducción de la complejidad existente en la jurisdicción de lo contencioso administrativo. Prueba de ello se encuentra en la reciente publicación de las sentencias proferidas por el Consejo de Estado durante el período comprendido entre el 4 de julio de $1991^{104}$ y el 2 de julio $2012^{105}$ a través de una investigación realizada por la Sala de Consulta y Servicio Civil del Consejo de Estado con el auspicio del Ministerio de Justicia y del Derecho (Las sentencias de unificación y el mecanismo de extensión de jurisprudencia, 2014).

Esta obra, producto de un valioso emprendimiento investigativo, brinda una herramienta que facilita la determinación de aquellas sentencias de unificación jurisprudencial contencioso-administrativa proferidas por el Consejo de Estado de acuerdo con los criterios de distinción fijados en el artículo 270 CPACA. De modo que la compilación de aquellas decisiones contribuya a la simplificación del proceso judicial encaminado a hallazgo de aquella sentencia aparentemente unificadora -desde el punto de vista

104 Fecha de promulgación de la Constitución Política de Colombia.

105 Fecha de entrada en vigencia de la Ley 1437 de 2011 "Por la cual se expide el Código de Procedimiento Administrativo y de lo Contencioso Administrativo". 
formal- y por tanto, directriz del mecanismo de extensión de efectos de la jurisprudencia administrativa frente al caso concreto.

No obstante lo anterior, si bien resulta importante el contenido de la mencionada obra, en términos de bibliografía de obligatoria referencia, es preciso señalar que los criterios de distinción o de identificación de las sentencias de unificación contencioso-administrativas seleccionadas conforme a la metodología de la trabajo presentado, evidencian, ante todo, un requisito formal en virtud del cual se le atribuye la vocación unificadora a una decisión que satisfaga los menesteres del artículo 270 CPACA.

Con todo, la determinación de los fallos de unificación conforme a las reglas precitadas, conlleva intrínsecamente el arbitrio judicial. De manera que, es posible que frente a un caso concreto $y$, a pesar que existan decisiones similares sobre equivalentes puntos de derecho, resulte inviable unificar la jurisprudencia a partir de la mera aplicación de los criterios expuestos en líneas precedentes, bien sea porque la ratio decidendi aplicable sea insuficiente para la resolución del caso futuro o, el caso futuro sujeto a unificación, no pueda regirse bajo los mismos estándares jurídicos y fácticos de una ratio decidendi previa.

Así pues, no pueden considerarse sentencias de unificación aquellas decisiones judiciales reiteradas, comúnmente aceptadas y por tanto, estables en el entorno jurídico nacional puesto que el status de sentencia unificadora corresponde a una categoría superior que no puede ser el producto de la constante y mecánica repetición a la manera de obiter dicta o de argumentos de autoridad (Santofimio, 2010, p. 67); todo lo contrario, la sentencia de unificación debe propiciar la aplicación de

[una] misma concepción jurídica y solución en Derecho, no por la vía de la costumbre o de prácticas históricas (...), sino, por el contrario, por la reiteración de sólidos y razonables argumentos jurídicos que han hecho vivencial el sistema jurídico garantizando plenamente la igualdad y la legalidad. (Op. Cit. p. 69).

De igual manera, es preciso que los razonamientos que se involucren en la sentencia de unificación aíslen o, al menos, no profundicen en la exposición de obiter dicta que, a pesar de cumplir una función contextualizadora e incluso pedagógica del procedimiento decisorio, pueden llegar a entrelazarse con la ratio decidendi, complicando el trabajo de diferenciar una de otra y, a la postre, dificultando el proceso de individualización de la solución de un caso concreto a través de la aplicación del mecanismo de extensión de jurisprudencia. Ello considerando que el papel del juez no es el de aprovechar las sentencias para dar opiniones de todo, así como tales 
pedagogías pueden tener usos perversos, como afirmar que como ello fue dicho por una alta Corte, constituye no su opinión sobre un tema, sino un precedente judicial que debe ser aplicado en casos posteriores en donde el problema jurídico concreto sí sea precisamente el asunto de que trató anteriormente el obiter. (Rojas, p. 118).

En vista de lo anterior, el efecto de unificación y su corolario mecanismo de extensión de jurisprudencia, exigen que mas allá de la satisfacción de elementos formales -requisitos del artículo $270 \mathrm{CPACA}$ - la sentencia unificadora debe encontrarse dotada de un contenido discursivo, argumental y decisorio que evidencie un trabajo jurisprudencial razonable y plausible en términos de su propia ratio decidendi y su consecuente decisum.

\section{CAPÍTULO III \\ EL LENGUAJE, LAS REGLAS Y LOS LÍMITES EN LA METODOLOGÍA}

La problemática derivada de la falta de unidad de la jurisprudencia incide directamente en los contextos sociales, de manera que la garantía de los derechos fundamentales de las personas a través de decisiones judiciales uniformes no sólo es un propósito constantemente perseguido toda vez que su implementación las múltiples fluctuaciones de la jurisprudencia local, las cuales impactan negativamente la percepción de la institucionalidad colombiana en la escena internacional.

Por ello, vale la pena precisar que con el fin de proponer una metodología de unificación jurisprudencial contencioso-administrativa es necesario hacer a un lado la visión e interpretación del derecho cerrada a la influencia de otros saberes científicos dando paso a la vinculación de otras áreas del conocimiento, puesto que "el pensamiento simplificador desintegra la complejidad de lo real, el pensamiento complejo integra lo más posible los modos simplificadores de pensar, pero rechaza las consecuencias mutilantes" (Morin, 2007, p. 22).

Con el ánimo de ambientar el acoplamiento estructural de éste capítulo, es necesario tener presente que, como anota Teubner (2005) "las palabras se entienden fácilmente, pero por desgracia el mensaje se ha perdido" ( $\mathrm{p}$. 20), ello comoquiera que mientras el contenido de la decisón judicial apunta hacia un sentido; sus efectos y posteriores interpretaciones, se enfilan con rumbo distinto. 
La exposición de algunas características del lenguaje jurídico resulta compleja si su explicación es pretendida a partir de la misma disciplina jurídica; bien, porque se tiene que empezar con una noción de autoridad u obligación (Moreno \& Ramírez, 2011, p. 29), o de convenciones de las primeras sociedades primitivas, las cuales obedecían por la misma influencia o presión social; de ahí que la noción de poder en tanto "medio de comunicación simbólicamente generalizado" (Luhmann, 2005c, p. 19) se encuentre presente a lo largo de la historia de las sociedades y es entendida como; sin embargo, frente a los deberes por cumplir, "en el caso de las reglas jurídicas esta consecuencia predecible es precisa y está oficialmente organizada" (Hart, 1998, p. 12); de modo que frente al fenómeno de surgimiento del sistema jurídico se sostenga que "en una primera etapa, lo que caracterizaba al Derecho es la existencia de una autoridad judicial paliando las insuficiencias de las reglas consuetudinarias, y cuya misión era imponer una solución aceptable a los conflictos que peligraban en degenerar" (Manassero, 2001, p. 344).

El enfoque pretendido parte de la consideración según la cual "las reglas de Derecho están formuladas en lenguaje natural, lo cual hace imposible su univocidad. Ello produce problemas de interpretación divergente que, a su vez, entrañan conflictos basados en intereses opuestos" (Manassero, p. 348) o dicho de otro modo, a la codificación de elementos del lenguaje corriente con pretensiones de impersonalidad y neutralidad (Moreno \& Ramírez, p. 32).

Para ello es necesario retomar algunos elementos fundamentales que, dada la cotidianidad del uso del lenguaje jurídico, han perdido o mutado su significado y ello no tanto por la ausencia de normas - de suyo abundantes en el ordenamiento colombiano- sino porque los significados yacen en zonas de penumbra en las que el lego especula sobre su valor semántico, el abogado comprende parcialmente y, el juez atribuye un sentido -acorde o no- al amparo de su autonomía y discrecionalidad.

En ese contexto, Foucault (2010) considera que "las teorías científicas o las interpretaciones de los filósofos explican por qué existe un orden en general, a qué ley general obedece, qué principio puede dar cuenta de él, por qué razón se establece este orden y no aquel otro" (p. 14); esta afirmación 
vertida a las divergencias del lenguaje señalan que, de manera previa a la comprensión del mismo, debe existir una serie de convenciones limitadas a un orden suficientemente claro que permita conectar la identidad del objeto y su posterior uso.

De este modo, se fijan las pautas que designan un orden a las cosas; sin embargo, "lo visto no reside jamás en lo que se dice" (Foucault, p. 27), de modo que será la propia sintaxis de las palabras las que orienten no solo su identidad con el objeto sino además su significado. En este punto, surge la metodología adecuada para el estudio de las palabras, puesto que

Si se quiere mantener abierta la relación entre el lenguaje y lo visible, si se quiere hablar no en contra de su incompatibilidad sino a partir de ella (...), es necesario borrar los nombres propios y mantenerse en lo infinito de la tarea". (Foucault, 2010, p. 27)

Ésta reflexión al parecer resulta menos usual de lo que se pudiera pensar en el campo del Derecho, puesto que el término jurídico se asemeja a algo referente más no como análisis en sí mismo lo cual demuestra que "la reflexibilidad permanece como algo desconocido para la teoría jurídica que refleja la praxis del derecho" (Luhmann, 2005a, p. 206).

A manera de ilustración se pretende exponer aquellas pautas y criterios lógico-metódicos que tienen por propósito la unificación jurisprudencial de la jurisdicción contencioso administrativo, no sin antes señalar que, en el capítulo siguiente, éste diseño se pondrá a prueba con miras a determinar su contrastabilidad frente a la praxis judicial.

En todo caso, se aclara que, como podrá observarse, cada una de las columnas que integran los criterios de formulación del precedente administrativo, poseen una alternativa abierta, la cual en todos los criterios es la última de ellas.

Sobre el particular, se precisa que, si bien es cierto que el propósito de la investigación es el aporte de una metodología que permita la unificación jurisprudencial contencioso-administrativa, la misma no pretende erigirse como un mecanismo cerrado ajeno a las necesidades y tendencias de la praxis judicial.

Con todo, tampoco se espera que la implementación de ésta propuesta metodológica resulte en modo tan discrecional que la opción prevista en cada uno de los criterios señalados resulte incompatible con la teleología y 
componente epistemológico de cada uno de los sub-ítems que integran la metodología de unificación presentada.

\section{Criterios de formulación del precedente administrativo}

- Contenido de la sentencia de unificación-

I. Definición del concepto jurídico

a. Conveniencia

$\underline{\text { b. Emulación }}$

c. Analogía

d. Simpatía

e.

B.

\section{EL CONCEPTO JURÍDICO}

En lo que concierne al estudio interno del lenguaje, y a partir de la propuesta hecha por Foucault, los fenómenos semánticos pueden explicarse a partir de las similitudes - conveniencia, emulación, analogía y simpatía-; todas ellas con sus caracteres especiales explicando aquella relación que la mente efectúa entre el objeto y su significado. No obstante, en cualquier caso es necesario comprender que "un cambio de una palabra puede cambiar radicalmente el significado de un enunciado; tal como un cambio de una letra puede cambiar radicalmente el significado de una palabra, y con ello el de una teoría" (Popper, 2002, p. 30).

En primer lugar Foucault expone la conveniencia. Se entiende por ésta "las cosas que, acercándose una a la otra, se unen: sus bordes se tocan, sus franjas se mezclan, la extremidad de una traza el principio de la otra" (Foucault, p. 36). Es decir, algunas raíces de las palabras se originan en un tronco común; sin embargo, la existencia de diversos significados tiende a variar la naturaleza del concepto a tal punto que lo diferencia de otros a pesar de su origen común. De allí que "la convenientia $($ sic) (...) pertenece al orden de la conjunción y del ajuste" (Foucault, p. 36). En vista de ello, algunas palabras se encuentran necesariamente sujetas a mutar, dado que 
el entorno incide sobre su uso y contenido semántico, situación que puede evidenciarse en las divergencias de significado resultantes de la actividad jurídica y aquellas del contexto profano.

En lo que respecta a la emulación, la distancia incide en la explicación del fenómeno; empero, la acogida de uno u otro modelo implica "ver y probar, si una de las alternativas en examen resiste el riesgo de ser sólo una alternativa" (Luhmann, 2005b, p. 11). Así, Foucault expone que a través de la emulación

"las cosas pueden imitarse de un cabo a otro del universo sin encadenamiento ni proximidad (...) sin embargo (...) deja inertes, una frente a otra, las dos figuras reflejadas que opone. Sucede que una sea la más débil y acoja la fuerte influencia de la que se refleja en su espejo pasivo" (Foucault, 2010, p. 38);

Como evidencia de lo expuesto, encontramos en el mundo jurídico diversidad de teorías enteramente aptas para la explicación o regulación de prácticas sociales dentro de sus contextos de producción; sin embargo, sucede que dichos modelos son trasplantados en entornos foráneos ajenos o disímiles al de su origen resultando desfigurados pese a que conserven su denominación o referencia.

En tercer lugar aparece la analogía, similitud cuyos rasgos la identifican como una sutil relación entre las cosas mas no como una semejanza notoria (Foucault, 2010, p. 39). Resulta usual que los procesos de conocimiento pretendan la descripción de fenómenos a partir de paradigmas preexistentes, de modo que, a manera de espejo, se crea un imaginario que permite determinar qué tanto se asemeja un objeto a otro -forma, contenido, características-. Esta tesis práctica, es de común usanza en la ciencia jurídica en donde la analogía se origina a partir de situaciones resueltas u homólogas por tener características comunes; no obstante, es claro que la respuesta jurídica no surge del mero cotejo de las situaciones, sino del examen crítico acerca de si la situación estudiada se amolda a una solución previa, sin tornar incompatibles ésta y aquella.

Por último, aparece la simpatía, la cual actúa de dos formas, siendo una de ellas, consecuencia de su antecesora: vuelve hacia el mundo de las cosas buscando acercamiento con los objetos cuyas cualidades resulten afines y, después de parecerse a aquélla, la transforma e incluso la convierte en algo que otrora no era (Foucault, 2010, p. 42). Por contraposición, es de anotar que así como las cosas pueden resultar idénticas o desnaturalizadas bajo el influjo de la simpatía, su opuesto - antipatía- evita que todas las cosas sean 
absorbidas y pierdan su esencia, de suerte que "mantiene a las cosas en su aislamiento e impide la asimilación; encierra cada especie en su diferencia obstinada y su propensión a preservar en lo que es" (Foucault, 2010, p. 42).

Ciertamente, en el contexto jurídico encontramos en múltiples manifestaciones las similitudes expuestas, por lo cual es forzoso reconocer que "para que exista una operación jurídica no basta cualquier comunicación, ya que entonces el sistema jurídico se desvanecería en la total congruencia con la sociedad. No basta tampoco la pura utilización de conceptos jurídicos o palabras que contengan resabios jurídicos" (Luhmann, 2005, p. 122),

Ahora bien, sucede que en el sistema jurídico las similitudes resultan imbricarse en forma tal que aquello que se dice del objeto puede fungir como regla para la interpretación de diversas situaciones. Ello a pesar de que, en ocasiones, la misma norma establece sus propios presupuestos de aplicación y dando lugar a que emerjan confusiones en torno al sentido del lenguaje, no tanto por la capacidad de la palabra de representar aquello de lo que se habla, sino porque su sentido ha sido fragmentado o mezclado con disposiciones disímiles o contradictorias entre sí.

A raíz de lo anterior, habría que preguntarse si las normas jurídicas - en sentido material - satisfacen las expectativas de la sociedad o si, en consonancia con el ordenamiento, corresponde al juez la tarea de trasformar el ordenamiento jurídico en respuesta a las demandas de sus destinatarios. De allí que "las leyes positivas, el objeto propio de la jurisprudencia, están relacionadas por medio de la semejanza, o mediante una analogía próxima o remota" (Austin, 2002, p. 141).

Por ello, resulta necesaria una postura de los jueces orientada a la formulación de precedentes a través de la unificación de sus decisiones a fin de que éstos constituyan "unidad para una posterior aplicación" (Luhmann, 2005b, p. 17).

\section{VOCACIÓN UNIFICADORA DE LA DECISIÓN JUDICIAL}

Atendiendo a los propósitos de ésta investigación, resulta necesario involucrar algunos elementos de la teoría de H. L. A. HART, bajo el entendido que se abordarán algunos elementos puntuales de su exposición dejando de lado los reparos que otros autores han formulado frente a sus tesis. Ello obedece a que la percepción de su obra, lejos de la lectura del sistema de derecho anglosajón, contiene diversidad de reglas metodológicas que sirven de insumo, para el diseño de una estructura del precedente, bien sea 
de manera directa o por interpretación de aquellas. En su obra, Hart ( $E l$ concepto de derecho, 1998) considera que, pese a que existe un conjunto de reglas con contenido predeterminado, cuya aplicación conduce a un único resultado-significado indiscutido de la regla, se presentan situaciones que no se ajustan a una estructura prediseñada y, por tanto, deben analizarse bajo distintos parámetros -duda sobre el significado de la regla-. (p. 15).

En ese contexto, surgen situaciones que, dotadas de un margen de dificultad, requieren que su respuesta jurídica se amolde o, al menos regule parcialmente dicho paradigma. Por ello, así como de un modo la semejanza dota de significado y sentido al lenguaje, acontece que en el derecho le es dable al juez definir con palabras y así encontrar "los límites o discriminar entre un tipo de cosa y otro, que el lenguaje distingue mediante una palabra separada" (Hart, 1998, p. 16). Así entendido, la solución o respuesta jurídica no se halla supeditada al derecho preexistente sino precisamente en que, a falta $-\mathrm{o}$ ante manifiesta dificultad- de cotejo entre el hecho y la norma, habrá que determinar si la solución puede darse empleando las demás similitudes - analogía, simpatía o emulación-. Por ello, señala Hart (1998) que "los diversos ejemplos de un término general están a menudo unidos entre sí de manera totalmente diferentes de la postulada por la forma simple de definición" (p. 19).

Hasta aquí, resulta notorio que aquello cuya respuesta se pretende desde el Derecho, no dista de manera ostensible en la atribución de sentido y contenido a que puede llegarse desde la teoría del lenguaje, de manera que no resulta sorpresivo el hecho que la aplicación de una norma, en punto de la interpretación de la regla particular, ha de ser interpretada "sobre la base de entendimientos generales" (Hart, 1998, p. 27).

En ese orden, la tarea del juez consiste en encontrar -o crear- la norma jurídica sobre la cual se erigirá el sentido de su decisión, del mismo modo que deberá apropiarse de razonamientos que fortalezcan y, por tanto, sean tolerables por sus destinatarios, incluso basándose en decisiones previas, de allí en algunos fallos resulte palmaria la argumentación de tipo ad hominem strictu sensu, esto es, "un argumento aceptable para auditorios particulares" (Giraldo, 1993, p. 16). Bajo el anterior enfoque, pareciera que cada juez imprime sin saberlo un razonamiento invisible en la construcción del derecho, la cual le resulta útil a sí mismo en la asunción de decisiones.

De igual manera, sucede que en los órganos judiciales colegiados, no siempre la posición adoptada es avalada ni apoyada por la totalidad o un 
sector mayoritario de la corporación, de manera que el efecto de la disidencia tiende a la generación de complejidad al interior de dichas estructuras, dependiendo, en éste caso, de la obra de la persuasión y el convencimiento de sus contertulios. Sin duda, éste ejercicio judicial contribuye a la creación del Derecho por parte de los jueces, en donde resulta lesionada la unidad, la coherencia y la estabilidad de las decisiones, reflejando que "la prevención contra la circularidad o la auto-referencia quedaron, en efecto desactivadas cuando se aplicaron a la praxis jurídica" (Salguero, 2002, p. 71).

Esto es, sin duda el mayor obstáculo epistemológico en aras de la creación del precedente en tanto elemento de reducción de la complejidad en el sistema de decisiones judiciales. Por tanto, es necesario poner cortapisas a un entorno que tiende a ramificarse de manera indefinida frente fenómenos como: la existencia de situaciones disímiles, pese a guardar semejanzas; el continuo proselitismo de los jueces que pretenden validar posiciones personales en aras de una pretendida renovación del derecho y; el permanente deseo, propio de la condición humana, de hacer triunfar visiones personales sobre la realidad de las cosas aún en contravía de principios como la seguridad jurídica y la estabilidad en las decisiones judiciales, tornando mucho más difícil la tarea unificadora. Aquí, al igual que como sucede en la unidad de la ciencia, Morin (2007) considera "solo [ésta] tiene sentido si es capaz de aprehender, al mismo tiempo, unidad y diversidad, continuidad y rupturas" (p. 77). De allí emerge el primer aspecto metodológico respecto de la unificación de jurisprudencia, sin que ello atente contra las "ciencias interpretativas, en cuanto que se ocupan de lo que posee sentido y significado" (Ross, 2007, p. 371).

En éste orden de ideas, se tiene como punto de partida el principio de unidad de las decisiones, cuya consolidación será posible una vez se supere el conflicto de criterios de identificación de cada cuestión jurídica central. Dicho de otro modo, la consecución del propósito de auto-reproducción de los fallos y la consecuente estabilización judicial implica suspender o en cierto modo, hacer cesar la continua creación jurisprudencial que, a la postre, genera mayor complejidad en éste sistema. Al respecto, Hart (1998) considera que "para aproximarnos al uso jurídico del precedente, debemos suponer que el padre se concibe a sí mismo, y es concebido por los demás, como adhiriendo a pautas tradicionales de conducta, y no como introduciendo pautas nuevas" (p. 156).

Por supuesto que de lo anterior se puede comprender cómo "las reglas no son ya un conjunto discreto inconexo, sino que, de una manera simple, están 
unificadas" (Hart, 1998, p. 118) bajo el entendido que ahora los juicios serán sistemáticos y no unitarios. De esta forma, al interior de las Corporaciones judiciales la dinámica de conceptualización varía en tanto "lo que constituye una organización, no es una regla de agregación de contenidos en forma de decisión por fijar, como por ejemplo un fin, sino ante todo un proceso de comunicación" (Luhmann, 2005b, p. 47). Por supuesto, es necesaria la integración de elementos adicionales; y ello obedece a que "las sentencias no pueden ser formuladas en términos generales y su uso como guías que señalan cuáles son las reglas, depende de una inferencia de algún modo frágil, hecha a partir de decisiones particulares" (Hart, 1998, p. 121).

De otra parte, y en consonancia con el criterio de unidad de las decisiones, es pertinente determinar si aquélla construcción jurisprudencial uniforme es comprobable en la práctica. Aquí es menester recordar que "si una teoría no funciona en la práctica, es falsa en la teoría" (Sartori, 2010, p. 142), por tanto, debe acudirse a la comprobación fáctica del precedente cuyo criterio de validación se basa en la coherencia.

En otras palabras, aquella proposición o razonamiento jurisprudencial uniforme y por tanto, permeable a las Salas de decisión de las Corporaciones judiciales, lleva consigo: 1) el proceso de adaptación de las circunstancias fácticas del caso según las formas de similitud-conveniencia, simpatía, analogía y emulación-; 2) la determinación de la regla o criterio interpretativo -decisión uniforme-y; 3) Determinar - a partir del material probatorio del caso- si la situación materia de análisis se encuentra cobijada dentro de la interpretación uniformemente aceptada, de suerte que el alcance de los enunciados judiciales explicativos del caso concreto, no controviertan el contenido material y jurídico - en tanto vinculante- desarrollado en decisiones antecedentes.

Aquí los conceptos jurisprudenciales y normativos entran en conjunción con el saber aplicado de la lógica pragmática, de manera que el problema jurídico -materia de la litis-encuentra respuesta dentro de criterios fijos o predeterminados en la decisión uniforme. De suerte que la solución del caso, con independencia de la tesis de la parte, halla cabida en el continuo y reiterado ejercicio sobre criterios prefijados y, en ese orden la decisión judicial sería el reflejo de la "operatividad práctica consolidada en instituciones, y en último análisis solidificada en historia" (Sartori, 2010, p. 97).

En este punto, podría afirmarse que el cometido de mantener la decisión uniforme de acuerdo con su comprobación práctica, le impone al juez una 
tarea ideológicamente sesgada. De acuerdo con ello, el operador jurídico - a pesar de su autonomía- se encontraría atado por incuestionables límites conceptuales, de modo que su actividad sólo tiene lugar si acata irrestrictamente dichos cánones; sin embargo, lo que hasta ahora resulta notorio es un propósito de estabilidad, sobre el cual debe indicarse, que sólo a través de la replicación el modelo, podrá permearse la actividad de los funcionarios judiciales en niveles jerárquicamente inferiores. Con todo, lo que hasta ahora se ha dicho corresponde a un diseño incomprobable sobre el funcionamiento de la actividad judicial y el propósito de la decisión uniforme, por lo cual es necesario atribuir el contenido o, dicho de otro modo, dotar de sentido a aquello que constituye la unidad de la decisión, es decir, el concepto.

Comúnmente el lenguaje jurídico carece de univocidad, situación que conduce a que en la práctica, una misma situación con relevancia jurídica pueda explicarse de distintas formas y que, sus diversas explicaciones sean a su vez contradictorias. De allí cobra importancia la determinación del concepto, entendido como aquello que se dice sobre una forma jurídica, aspecto en que la similitud por simpatía pareciera gobernar el universo conceptual del derecho al punto de crear o transformar la naturaleza del objeto. En vista de lo anterior, es claro que el contenido fundamental de la unidad de la jurisprudencia no puede librarse a las continuas fluctuaciones sobre el alcance de los conceptos jurídicos, siendo necesario determinar qué aspectos de determinado concepto resultan aplicables en un caso concreto y cuales aspectos deben descartarse. Por ello, Foucault (2010) señala que "toda semejanza será sometida a la prueba de la comparación, es decir, no será admitida sino una vez se encuentre, por la medida, la unidad común o más radicalmente por el orden, la identidad y la serie de las diferencias" (p. 71).

Teniendo en cuenta la premisa anterior, es necesario involucrar y acoplar criterios que permitan superar el dilema que antecede. Para tal efecto, las categorías de "connotación"-conjunto de las características o propiedades que constituyen un concepto (Sartori, p. 79)-y "denotación" -la clase de objetos a la cual se aplica el concepto (Ibíd.)- ofrecen criterios de análisis sobre el interrogante planteado.

En primer lugar, es forzoso determinar los elementos internos del concepto jurídico hallados en la norma o el fallo, los cuales, orientados bajo el sentido de la connotación, no resulten modificados por vía de argumentación o interpretación en fallos posteriores. Bajo estas circunstancias, "está claro 
que cuanto mayor sea el radio comprensivo de un concepto, tanto menores serán las diferencias que de él se captan" (Sartori, 2010, p. 293), y; en esa orientación, tiene lugar la denotación, la cual constituirá la forma en que los conceptos y su alcance previsto en decisiones judiciales previas, constituirán el punto de partida en las decisiones posteriores.

Este elemento de la denotación coincide con la tesis de Hart, puesto que con independencia de la descripción de la palabra, ésta "solo tiene que reconocer ejemplos en términos verbales claros, que "subsumir" hechos particulares bajo rótulos clasificatorios generales y extraer una simple conclusión silogística" (Hart, 1998, p. 157). No obstante, en cuanto a la determinación precisa del concepto aplicable al caso, Hart arguye que "el lenguaje de la regla se limita a destacar un ejemplo revestido de autoridad, a saber, el constituido por el caso obvio. Este puede ser usado de manera muy análoga a un precedente" (Hart, 1998, p. 159). Aquí se entrecruzan las ideas expuestas en forma deductiva, al punto que la concepción sobre aquello que Sartori llama denotación, equivale en la tesis de Hart a "congelar el significado de la regla, de modo que sus términos generales tengan que tener el mismo significado en todos los casos en que su aplicación está de por medio" (Hart, 1998, p. 161).

Al respecto, si se afirmara que la ciencia jurídica parte de la observancia de las pautas generales de la teoría del lenguaje y, corolario de ello, resultara notoria la reducción de la complejidad del sistema judicial en punto de la vinculación directa con los cánones del precedente, podría objetarse esta articulación de conceptos a la luz del cúmulo de conflictos que presenta el derecho, del mismo modo en que son innegables aquellas divergencias -simpatías- que crean los operadores jurídicos. De allí que la idea del concepto uniforme resulte, en últimas, extraña en la concepción Hartiana del Derecho en tanto afirma que el juez toma distancia de la idea de un concepto que sirva de fundamento en la decisión uniforme, por un lado y, señalando el estado de caos dentro del cual un enunciado normativo, jurídico o jurisprudencial presenta diversidad de significados. En sus palabras:

"Primero, no hay ningún método único para determinar la regla respecto de la cual es autoridad un determinado precedente al que se reconoce autoridad. (...) En segundo lugar, ninguna formulación de una regla que tiene que ser extraída de los casos puede pretender ser la única correcta. (...) en tercer lugar, (...) los tribunales que resuelven un caso posterior pueden llegar a una decisión contraria a la de un precedente restringiendo la regla extraída de éste, y acogiendo alguna 
excepción antes no considerada, o que, si lo fue, quedó abierta. (...) Por otra parte, al seguir un precedente los tribunales pueden dejar a un lado una restricción que aparece en la regla tal como fue formulada en el caso anterior en base a que ella no es exigida por ninguna regla establecida por ley o por un precedente previo. Hacer esto es ampliar la regla". (Hart, 1998, pp. 167-168).

En sustento de su aserción, Hart (1998) se apoya en la textura abierta del derecho, en donde el desarrollo de aspectos jurídicos corresponde a sus operadores (Cfr. p. 168). De allí que, desde la instrucción jurídica básica, se asimilen locuciones como "El derecho (la constitución) es lo que los tribunales dicen que es" (Hart, 1998, p. 176) en donde se evidencia que la actividad judicial supera al hecho de la norma jurídica. Con esto, la práctica judicial contribuye a la inestabilidad del sistema de derechos y garantías cuya tutela corresponde a los mismos jueces. Surge de lo expuesto que, en cuanto al derecho "[éste] es quien produce todas las distinciones y descripciones que utiliza, y que la unidad del derecho no es más que el hecho de su autoproducción: "autopoiesis" (Luhmann, 2005a, p. 85).

Sumado a la situación esbozada, es conocido el rechazo que algunos sectores de la doctrina y de la judicatura manifiestan frente a los precedentes judiciales. Incluso, como se anotó en el capítulo anterior, pudo observarse la manera en que la discrecionalidad judicial incide en la interpretación del texto constitucional, de modo que el peso de la decisión se deja a un lado para "distinguir idealmente, dentro de la persona psicológica del juez, entre la instancia normadora y la que está sujeta a las normas -entre la mejor convicción y la decisión de hecho-" (Ross, 2007, p. 174), del mismo modo en que se indaga acerca de "qué es lo que vincula de un precedente" (Ibíd.). Ésta circunstancia, en la práctica, favorece la desorganización del sistema judicial al punto que, como señala Ross (2007) "si el juez confronta un precedente supuestamente vinculante, siempre podrá decir que interpreta ratio decidendi en un sentido que hace que en el caso actual no se halle vinculado por dicho precedente" (p. 175).

Según lo evidenciado, la obra de Hart presenta elementos importantes en el diseño de pautas metodológicas de unificación jurisprudencial; no obstante, el desajuste encontrado exige que su superación se aborde desde una óptica distinta a la teoría del Derecho, dado que el escenario jurídico per se no sólo ha generado mayor complejidad sino que además resulta insuficiente. De modo que, en palabras de Luhmann (2005a) "no queda 
otro camino que intentarlo con teorías de mayor poder de ordenamiento y de una más alta complejidad estructural" (p. 85).

\section{LA FUNCIÓN DE LA DECISIÓN JUDICIAL}

A partir de la dicotomía entre el acatamiento o no del precedente, es notorio el hecho que la asunción de una postura u otra, radica específicamente en el uso del lenguaje y su incidencia en las proposiciones jurídicas de los operadores. De suerte que los problemas verbales terminan anteponiéndose al estudio de las cuestiones reales (Cfr. Popper, p. 25).

Sin embargo, aquí es preciso diferenciar entre aquello que Popper (2002) denomina "las filosofías del significado y las filosofías del lenguaje" (p. 29); en donde, a juicio del autor, tienen mayor relevancia aquellas relacionadas con la verdad que aquellas referentes al significado, por lo que será necesario examinar la dualidad que se presenta en torno a un mismo concepto, esto es, la idea.

Al respecto, resulta que son temas distintos "las designaciones o términos o conceptos" y "los enunciados o proposiciones o teorías", a partir de lo cual es posible determinar si el contenido del lenguaje está asociado con elementos vagos e imprecisos (el significado) o con teorías (la verdad).

El lenguaje y su búsqueda por la mejor definición que se acomode a un término, puede correr el riesgo de ser un simple significado no susceptible de verificación con la realidad $\mathrm{y}$, ante tal situación, las proposiciones o enunciados construidos al amparo de ambigüedades corren el riesgo de ser insostenibles si no superan mecanismos de comprobación. (Popper, 2002, p. 50). Por lo anterior, deriva irremediable el hecho de soslayar la cuestión del lenguaje jurídico y su problemática representación para dar paso a la observación, a partir de la singularidad de su experiencia, aspectos metodológicos que podrían corroborar los posibles resultados de la investigación.

En éste punto, dado que el Derecho guarda relación con las expectativas, es necesario que la práctica de la jurisdicción se encauce reiteradamente en la reducción de aquellas, de lo cual se sigue que el decrecimiento de expectativas ${ }^{106}$ contribuiría al aminoramiento de la complejidad puesto que

106 Entendidas como "no sólo el estado actual de conciencia de un individuo determinado, sino el aspecto temporal del sentido en la comunicación”. (LUHMANN, 2005a, p. 182). 
las repeticiones que hacen posible las condensaciones y las confirmaciones que las acompañan, reducen el espectro de la arbitrariedad de la relación entre signo y significante" (Luhmann, 2005a, p. 185). A partir de ésta formulación, es posible superar las refutaciones en torno a la vinculación del precedente y la textura abierta, toda vez que en tales objeciones "la manipulación de los conceptos es obvia, de manera que los resultados [en las decisiones anti-precedente] no hacen otra cosa que mostrar los prejuicios con los que se inician las investigaciones. Si la discusión permanece en éste nivel, incluso las posiciones contrarias no son sino la articulación de otros prejuicios." (Luhmann, 2005a, p. 213).

Con todo, lo expresado debe entenderse en el sentido que no se descarta la textura abierta como mecanismo de justificación del contenido de una decisión judicial, toda vez que no es posible mantener incólumes e inmutables conceptos relacionados con el reconocimiento y el alcance de los derechos fundamentales, por ejemplo; sin embargo esta apertura no incide de igual manera en el reconocimiento de los derechos contenidos en las disposiciones de rango legal y aquellas jerárquicamente inferiores, por lo es forzoso retomar a Foucault y Hart bajo el entendido de que "el significado o relevancia de una teoría (...) depende de contextos muy comprehensivos, aunque, por supuesto, la relevancia de esos contextos depende, a su vez, de las diversas teorías, problemas y situaciones problema de los que se componen" (Popper, 2002, p. 34), esto es, mantener una relación entre los puntos de vista de los autores, en donde los apartes teóricos de cada uno contribuyen a la construcción del propósito de ésta investigación, sin olvidar que "no podemos, por tanto, conocer nunca, o entender, todas las implicaciones de una teoría, o su total relevancia" (Popper, 2002, p. 37).

Lo hasta aquí expuesto evidencia un ambiente en el que los postulados descritos resultan insuficientes per se frente al objetivo de la investigación, por tanto, cobra relevancia el hecho de determinar los objetivos de la decisión judicial con vocación de vinculatoriedad, de manera que los casos que le sucedan encuentren en una práctica judicial constante y repetitiva previa, elementos que cumplan la función de preservar el precedente, por un lado y, no coartar la autonomía judicial en circunstancias de interpretación por textura abierta o inaplicación parcial del precedente. Sobre lo cual el necesario resaltar que la decisión del operador jurídico debe ajustarse a uno de los modelos -funciones- del precedente.

En concordancia, es preciso señalar como primera medida, la función del precedente orientada a la unificación de criterios, de ahí que, en primer 
lugar las decisiones del órgano judicial den cabida al asentamiento de posturas jurídicas, por cuanto resulta necesario evitar aquellas pretensiones de universalidad del concepto jurídico en donde "la idea de un lenguaje preciso, o de precisión del lenguaje, parece estar, por entero, mal concebida" (Popper, p. 32), de manera que la precisión resulte más exigente que la propia situación problema y consecuentemente se pierda la claridad del concepto. Con ello se evita el error de asociar la unificación jurisprudencial bajo el entendido de encontrar los argumentos judiciales fuertes tanto como si fueran igualdades matemáticas, esto es, esquemas precisos de respuesta ante los fines de la norma.

Debe tenerse en cuenta que la estructura judicial del Estado, se encuentra al servicio de la satisfacción de pretensiones particulares, en mérito de lo cual, no pueden atribuírsele efectos irradiadores a una decisión aislada. Pese a ello, si en la decisión se encuentran argumentos que contribuyen al incremento de la precisión o la exactitud del concepto jurídico, éste elemento "tiene sólo un valor programático como medio para un fin definido" (Popper, 2002, p. 32). Por tanto, el propósito radicará en reducir el campo de aplicación del concepto, en donde interactúen proposiciones particulares -regla que gobierna el caso- con proposiciones individuales -caso concreto- en una relación de coordinación y subordinación.

Siguiendo las ideas presentadas, "los procesos de allanamiento de las diferencias se realizan a través de un procedimiento contencioso de tipo jurídico, y se juega, por así decirlo, con fuego: con la incertidumbre de los resultados, con costes y retrasos" (Luhmann, 2005a, p. 219). Es en este punto donde la complejidad resulta tangible frente a la decisión judicial; sin embargo, dado que lo pretendido es el control o reducción de la misma, surge un segundo elemento externo de la función del precedente, esto es, la previsión, entendida como aquella situación en la que la corporación judicial proyecta su decisión para cuestiones futuras en temas concretos, esto es, persigue "todo incremento en claridad" (Popper, 2002, p. 32) al momento de sentar una postura evitando situaciones que, en un momento posterior, impliquen el rediseño del precedente. Las eventualidades que resultan del concepto de textura abierta o la relatividad del precedente logran superarse, no en función del obstáculo epistemológico que tales conceptos pueden ofrecer, sino reconociendo la capacidad de aclarar aquello que se dice sobre una idea jurídica concreta.

De este modo, la función del precedente será anticipativa, lográndose con ella la pretensión de seguridad jurídica en donde "solo un almacenamiento 
semántico (...) [destinado] al uso repetido conduce a consolidaciones en el tiempo" (Luhmann, 2005a, p. 184). Esta situación resultará favorable no sólo en la adopción de determinada postura judicial -ponencia de la decisión-, sino que además, dada su finalidad puede permear el criterio del órgano colegiado judicial solidificando los diversos conceptos jurídicos cuyo contenido práctico resulta del estudio del caso concreto, de manera que "siempre que incrementa o disminuye la fuerza lógica, o el poder, o la cantidad de información de una teoría, deben incrementar o disminuir igualmente tanto su contenido lógico como su contenido informativo" (Popper, 2002, p. 35).

\section{CAPÍtUlo IV}

\section{PRIVACIÓN INJUSTIFICADA DE LA LIBERTAD: APROXIMACIÓN A UNA PROPUESTA DE UNIFICACIÓN JURISPRUDENCIAL}

\section{A. ANTECEDENTES}

Un cuestionamiento acerca de la eficacia y la eficiencia de la administración de justicia nacional, arroja resultados poco alentadores en tanto se persigue la garantía de los derechos consagrados en la Constitución y sus subproductos reflejados en las distintas codificaciones, leyes, estatutos, reglamentos y estipulaciones particulares. Como prueba de ello, "desde el año 1995, la demanda de justicia ha aumentado en un $98.2 \%$; en aquella época ingresaron 898.162 procesos y en 2008 esta cifra había aumentado a 1.783.670 casos; demanda que ha crecido a un ritmo más acelerado que el de la oferta, ya que de 4.012 jueces y magistrados que había en el 95, se pasó a 4.237 funcionarios; esto quiere decir que la oferta sólo creció un 5.6\%." (Herrera, 2013, p. 324)

Sumado a esta notoria ausencia de oferta, pululan las causas de la congestión en la Rama Judicial, entre las que se destacan: la excesiva duración de los procesos judiciales, la falta de recursos económicos de la Rama Judicial, la insuficiente capacitación -actualización- de los jueces, la ausencia de estrategias de sustanciación de los procesos, el ritualismo de los operadores jurídicos y la abultada litigiosidad corolario de la falta de empleo de Mecanismos Alternativos de Solución de Controversias entre las partes. (Torres, 2002). 
Visto lo anterior, pareciera ser que la congestión en los despachos judiciales del país es invulnerable frente a las medidas adoptadas por el Congreso de la República, la Rama Judicial y los Ministerios de Justicia y Hacienda, reflejando que, en la práctica, cualquier esfuerzo encaminado a su mitigación resulta irrisorio frente a la excesiva demanda de justicia de la sociedad. Así por ejemplo, el sinnúmero de estrategias normativas encaminadas a la descongestión de la judicatura atraviesa los más variados escenarios abarcando la creación de Tribunales con salas especiales de descongestión, la promoción e incentivo de los mecanismos alternativos de solución de controversias $^{107}$, reformas constitucionales y de leyes estatutarias ${ }^{108}$ así como la modificación y adopción de los códigos de procedimiento ${ }^{109}$, sin que, pese a su loable propósito, hayan disminuido notablemente el represamiento de procesos en los despachos judiciales.

Dentro de este escenario, la Jurisdicción de lo Contencioso-Administrativo ha emprendido, en concordancia con el reciente Código de Procedimiento Administrativo y de lo Contencioso Administrativo -CPACA- la tarea de reducir la complejidad de sus propias controversias y controlar el volumen de procesos existentes para su decisión en sede de segunda o única instancia. Prueba de ello puede encontrarse en la organización estructural originada con la otrora acción, hoy medio de control, de reparación directa, en donde, a diferencia de lo que ocurre en la jurisdicción ordinaria civil, no existen procedimientos diferentes para las numerosas modalidades en que se desarrolla la responsabilidad del estado al tenor del artículo 90 Constitucional, de suerte que ha correspondido a la jurisprudencia administrativa la clasificación de las distintas modalidades que puede asumir un solo medio de control contencioso administrativo.

Así, puede observarse que los títulos de responsabilidad administrativa, a pesar de sus diversas fuentes, presentan al interior de la Sección Tercera del Consejo de Estado un grado de esquematización -situación que no implica

107 Cfr. Ley 23/1991, Dto. 1818/1998, L. 446/1998, L. 640/2.001 y L. 1563/2012.

108 Acto Legislativo 03/2002 y Ley 1258/2009 reformatoria de la Ley 270/1996 "Estatutaria de la Administración de Justicia". En virtud de éste último se dispuso la ampliación del número de magistrados del Consejo de Estado.

109 Cfr. Decreto 2282/1989, Dto. 2651/1991 (Sobre descongestión judicial, prorrogado en tres oportunidades mediante las leyes 192/1995, 287/1996 y 377/1997), Ley 446/1998, L. 600/2000, L. 712/2001, L. 794/2003, L. 906/2004, L. 1194/2008, L. 1395/2010 y por último la promulgación de las leyes 1437/2011 (Código de Procedimiento Administrativo y de lo Contencioso Administrativo) y 1564/2012 (Código General del Proceso). 
necesariamente la unidad de discurso ni mucho menos, la consolidación de precedentes-como se verá posteriormente:

\section{$\underline{\text { Responsabilidad administrativa }}$}

Constitución Política, Artículo 90

Medio de control: Reparación directa

Código Contencioso Administrativo (Dto. 01/19849) Art. 86

Código de Procedimiento Administrativo y de lo Contencioso Administrativo (L. 1437/2011) Art. 140.

\section{$\underline{\text { Supuestos constitutivos de responsabilidad administrativa }}$}
a. Daños a la propiedad y a la libertad económica
i. Ocupación de bienes
ii. Bodegaje de mercancías
iii. El servicio notarial
iv. El servicio registral
v. Liquidación de entidades financieras

b. Administración de Justicia

i. Error judicial

ii. Privación injusta de la libertad

iii. Indebido funcionamiento de la administración de justicia
c. El hecho del legislador
e. Actos terroristas
g. Reclusos en centros carcelarios o de detención

i. Actividad médica

k. Actio in rem verso d. Actividades peligrosas

f. Incumplimiento del deber de protección y seguridad por parte del Estado

h. Daños a miembros de la fuerza pública

j. Violación a Derechos Humanos

1. Acción de repetición

Con todo, como se dijo al principio de ésta investigación, el propósito de unificar -Arts. 270 y 271 CPACA-y, en consecuencia, extender los efectos de la jurisprudencia -Arts. 102 y 269 ibídem- contencioso administrativa es relativamente reciente si se tiene en cuenta la entrada en vigencia de la Ley 1437/2011 -2 de julio de 2012-. Adicionalmente, nótese que el motivo de unificación jurisprudencial resulta ser excluyente, fijándose en aquellas decisiones que se hayan proferido por importancia

110 Reformado mediante Decreto 2304/1989 Art. 16 y la Ley 446 de 1998 Art. 31. 
jurídica, trascendencia económica o social o por necesidad de unificar o sentar jurisprudencia. Situación en la que nuevamente la textura abierta pareciera abrirse camino.

En vista de lo anterior, el cuestionamiento es patente: ¿Cuál es el criterio para determinar importancia jurídica, trascendencia económica o social o necesidad de sentar jurisprudencia, que ameriten la expedición de una sentencia de unificación jurisprudencial? Por lo que resulta necesario insistir en que su respuesta no se base en la mera liberalidad del ponente ni mucho menos de la sala de decisión. Todo lo contrario, se espera que el motivo de unificación encuentre asidero razonable y que interprete la realidad de la sociedad o de fenómenos cuyas consecuencias están siendo deferidas a la solución de la jurisdicción de lo contencioso-administrativo, tal y como ocurre con la privación injustificada de la libertad.

De otra parte, en cuanto al mecanismo de extensión de la jurisprudencia, la incertidumbre es aún mayor. Haciendo a un lado la sentencia de unificación y sus efectos, el ciudadano se encuentra expuesto a la transgresión de los derechos fundamentales a la igualdad y, potencialmente, de acceso a la justicia, en los eventos en que la solicitud de extensión a juicio de la autoridad no se adecue a los presupuestos de unificación jurisprudencial, de modo que, pese a la existencia de un fallo con la potencialidad de reducir la congestión judicial, el arbitrio de servidores públicos y de oficinas jurídicas de entidades estatales pueden hacer nugatorios los efectos de las sentencias unificadoras.

Por ello, será menester anotar que a la par de la sentencia de unificación, corresponderá al Consejo de Estado, establecer con la mayor claridad y pedagogía las pautas dentro de las cuales se enmarcarán los supuestos de extensión jurisprudencial de la decisión proferida, evitando tajantemente cualquier interpretación deformadora del contenido de la sentencia por parte de la autoridad y, garantizando en esta medida las funciones de asentamiento y previsión enunciadas en el capítulo precedente.

\section{B. \\ LAPRIVACIÓN INJUSTADE LALIBERTAD EN LO CONTENCIOSO- ADMINISTRATIVO}

El aparato estatal representa para los ciudadanos una restricción tolerable y soportada en común frente a las libertades individuales en aras de la convivencia pacífica de la sociedad. En éste sentido, las políticas estatales 
y la acción de las autoridades públicas se encaminan a la prevención, vigilancia e incluso el control de aquellas conductas que pueden resultar lesivas no sólo del ordenamiento jurídico sino que además pueden impactar negativamente la armonía social.

$\mathrm{Al}$ respecto, el establecimiento de códigos y leyes de orden sancionatorio ponen de presente el grado de control e intervencionismo que el Estado tiene en las conductas de sus administrados, al punto que los diversos regímenes punitivos estatuyen restricciones de diversa naturaleza al ejercicio de las libertades fundamentales -entre otras, de locomoción, de ejercicio del comercio, libertad personal-, de suerte que las limitaciones impuestas por los órganos competentes, exigen que sus decisiones se realicen al amparo de absoluta autonomía decisional y funcional -aspecto extrínseco-, así como también les resulta exigible que en sus determinaciones se satisfagan estándares de proporcionalidad y razonabilidad -aspecto intrínseco-dado que sus disposiciones tienen la virtualidad de coartar o restringir tales garantías.

Baste lo anterior para señalar que los impedimentos que las autoridades imponen al ejercicio de las libertades individuales son igualmente situaciones objeto de control por parte de la Jurisdicción de Contencioso-administrativo, de allí que los actos emitidos en ejercicio de los poderes Disciplinarios, de Control Fiscal y aquellos relacionados con la actividad de juzgamiento propia de la Rama Judicial del Estado, hallan en el control jurisdiccional el juicio sobre su razonabilidad, proporcionalidad y correspondencia con la presuntas infracciones a las normas sancionatorias. De allí emerge la privación injusta de la libertad como unos de los supuestos constitutivos de responsabilidad de la administración, en donde, como se expondrá, existen divergencias y contradicciones en cuanto a su tratamiento dentro del régimen de daños, al punto que sus manifiestas variaciones ponen en riesgo el principio de seguridad jurídica y el derecho a la igualdad referido al proferimiento de decisiones consistentes.

Con la entrada en vigencia de la Constitución de 1991, la Ley Estatutaria de Administración de Justicia - Ley 270/1996- consagró la responsabilidad del Estado por la acción u omisión de los agentes judiciales y, de manera específica el artículo 86 de la mencionada ley determinó la responsabilidad estatal por privación injustificada de la libertad, confiriéndole al afectado el derecho a demandar el pago de perjuicios. De otra parte, desde el punto de vista de las codificaciones procesales penales vigentes en sus respectivos momentos ${ }^{111}$, sólo una de éstas reconoce expresamente la

111 Decreto 2700/1991, Ley 600/2000 y L. 906/2004. 
privación injustificada de la libertad y el derecho a obtener indemnización por dicho concepto. Mientras que en las restantes, el supuesto constitutivo de responsabilidad deriva de la acreditación de la existencia de un daño antijurídico en los términos del artículo 90 de la Constitución Política, inclusive bajo aquellos supuestos en que se recupera la libertad personal con base en la aplicación del principio in dubio pro reo.

En base a lo expuesto, es pertinente dejar por sentado que: i) no se pretende ahondar en el contenido de las posturas y razonamientos de los Consejeros de Estado intervinientes sino determinar los criterios que han dado lugar a las oscilaciones jurisprudenciales; ii) tampoco será materia de análisis si los accionantes particularmente considerados acreditaron la configuración de los supuestos constitutivos de responsabilidad de la administración y; iii) no se preferirá ninguno de los títulos de imputación sobre privación injustificada de la libertad puesto que la escogencia de una de las alternativas implica renunciar al reconocimiento de criterios distintos. Sin embargo, sobre éste último punto, se deja claro que, en tanto aprovechen a la prueba de la estructura prediseñada, se extraerán sin distinción los componentes de los criterios de imputación.

Como primera medida, es necesario precisar el alcance que el concepto de privación injusta de la libertad se enmarca dentro de los cánones que la Corte Constitucional (C-037, 1996) fijó, en el sentido de considerar que dicha privación es "abiertamente desproporcionada y violatoria de los procedimientos legales, de forma tal que se torne evidente que la privación de la libertad no ha sido ni apropiada, ni razonada ni conforme a derecho, sino abiertamente arbitraria". Esta definición que, en principio pudiera delimitar el entorno comprensivo de la privación injusta de la libertad, peca por defecto en la medida en que la privación de la libertad por orden judicial puede acontecer con independencia de la observancia o desacato de las normas legales (Exp. 10299, 1996). Aquí, es pertinente anotar que en el ordenamiento jurídico colombiano, la imposición de la medida preventiva de aseguramiento, en ningún momento implica la desobediencia al postulado constitucional de presunción de inocencia, pese a que en la práctica, ésta situación comporte igualmente la privación de la libertad individual.

La persona que otrora fuera privada de su libertad debería iniciar el medio de control de reparación directa dentro de los dos (2) años siguientes contados a partir de la ejecutoria de la providencia judicial que dispuso dejarle en libertad a fin de obtener el pago de la indemnización por los perjuicios que le fueron irrogados. Asimismo, es preciso señalar que, contrario a las disposiciones encontradas en el Código Contencioso Administrativo-Decreto 01/1984-y el 
Código de Procedimiento Administrativo y de lo Contencioso-Administrativo -Ley 1437/2011- respecto de la competencia para el conocimiento del medio de control mencionado, corresponde, en primera instancia, a los Tribunales Administrativos, incluyendo aquellos cuya cuantía sea inferior a la suma equivalente a los 500 SMLMV. (Exp. 34985, 2008).

Con base en lo anterior, las decisiones que la justicia penal adopta tendrán incidencia en la jurisdicción contencioso-administrativa en los siguientes eventos:

i) Captura sin el lleno de requisitos legales, derivada de la acción defectuosa de los órganos estatales de policía judicial;

ii) Insuficiencia probatoria y argumental de la Fiscalía General de la Nación, por cuya manifestación no logra acreditarse la responsabilidad penal del procesado con privación de la libertad y;

iii) Imposición de medida de aseguramiento en debida forma pero, en desarrollo del proceso, se absuelve al implicado.

Inicialmente, el artículo 414 del Dto. 2700/1991 precisaba que el derecho a la indemnización de perjuicios deriva de los supuestos de sentencia absolutoria definitiva o su equivalente; porque el hecho no existió; o bien el sindicado no lo cometió o; en razón a que la conducta no constituía hecho punible - presupuestos objetivos de responsabilidad de la administración-; sin embargo, adviértase que a pesar que la disposición en comento se encuentra derogada, el Consejo de Estado (Exp. 13168, 2006c) (Exp. 15463, 2007) precisó que dicha disposición mantendría su vigencia para definir la responsabilidad del Estado inclusive con posterioridad a la entrada en vigencia la ley 270 de 1996 "pero no como aplicación ultractiva de la norma sino de los supuestos previstos en ella" (Exp. 19312, 2010).

Históricamente, la jurisprudencia contencioso-administrativa referente a la privación injusta de la libertad se ha desarrollado en líneas argumentales disímiles y excluyentes entre sí: En una primera etapa, con base en la tesis de la falla del servicio 112 y la interpretación de las causales del artículo 414 del Decreto 2700/1991, la declaratoria de responsabilidad administrativa

112 Esta modalidad, se refiere al incumplimiento del contenido obligacional que tiene la administración frente a sus administrados. Dicho contenido obligacional puede tener dos fuentes: i) Estatutos o leyes especiales que regulen la prestación del servicio por parte de la administración o; ii) genéricamente, a partir de la violación del artículo $2^{\circ}$ de la Constitución Política sobre los fines del Estado.

De otra parte, la declaratoria de responsabilidad de la administración, exige la acreditación de los siguientes requisitos: i) El afectado sufre un daño antijurídico; ii) El servicio tuvo deficiente funcionamiento, o bien funcionó en forma inoportuna o 
tenía lugar cuando se presentaban comportamientos irregulares de las autoridades del Estado en forma tal que redundaban en desmedro de la libertad personal (Exp. 9734, 1994a). De igual manera, se señalaba que el funcionamiento defectuoso de la administración de justicia, comprendía, entre otros supuestos, la privación injusta de la libertad (Exp. 7058, 1992).

Al mismo tiempo, se consideraba que dicha privación se producía "con abstracción de la conducta o de las providencias dictadas por las autoridades encargadas de administrar justicia" (Ibíd.), postura jurisprudencial sujeta al condicionamiento de la existencia de providencias contrarias al ordenamiento jurídico, de modo que "se ubica en el ámbito de la responsabilidad directa del Estado por error judicial, que se produce como consecuencia de la violación del deber que tiene todo juez de proferir sus resoluciones conforme a derecho" (Exp. 9391, 1994c). De la misma forma, dado que los eventos de detención se producían en el marco de una investigación penal, dicha circunstancia constituía una carga que todas las personas debían soportar, "de manera que la absolución final no es indicativa de que hubo algo indebido en la detención" (Exp. 8666, 1994b).

A la par de la producción jurisprudencial restrictiva, la interpretación del artículo 414 del Decreto 2700/1991 fue morigerándose al punto de considerar que los eventos descritos en la norma en comento, constituían causales objetivas de responsabilidad de la administración; empero sostuvo que si se tratara de situaciones ajenas a los eventos previstos en la norma, el régimen de responsabilidad seguiría siendo, por lo cual correspondía al demandante la carga de acreditar el error jurisdiccional derivado no sólo del carácter "injusto" sino "injustificado" de la detención. (Exp. 10056, 1995)

Así pues, los razonamientos de la jurisdicción contencioso-administrativa fueron flexibilizándose al punto de considerar supuestos de responsabilidad administrativa por situaciones independientes a las condiciones normativas del otrora código de procedimiento penal.

Es un tipo de responsabilidad objetiva en la medida en que no se requiere la existencia de falla en el servicio, razón por la cual no tiene ninguna incidencia la determinación de si en la providencia que ordeno la privación de la libertad hubo o no error judicial; y no es posible la exoneración de la responsabilidad de la administración con la sola prueba de diligencia que

equivocada y; iii) la existencia de una relación de causalidad entre la producción del daño al afectado como consecuencia de la falla del servicio. 
en este caso se traduciría en la demostración de que la providencia estuvo ajustada a la ley.

Para ilustrar esta circunstancia, el Consejo de Estado puntualizó que la falta de actividad probatoria por parte del Estado no corresponde a una carga que tengan que soportar los sindicados privados de la libertad y, en igual sentido, en relación con el principio in dubio pro reo, anotó:

$[\mathrm{N}]$ o debe olvidarse que el presupuesto de la aplicación de tal principio, supone una duda para el juzgador penal, lo cual evidencia, precisamente, la deficiencia de la actuación estatal en la labor probatoria, circunstancia que no puede servir de base, ni por asomo, para la exoneración del Estado por la privación injusta de la libertad, pues ha de tenerse presente que, como principio fundamental informador de toda la normativa penal, están los de buena fe y de inocencia, los cuales no pueden desvanecerse y mucho menos inobservarse, por una circunstancia meramente probatoria. (Exp. 11754, 1997).

Sobre éste aspecto, vale la pena resaltar el hecho que, si bien el Consejo de Estado acogió un elemento ajeno a las causales del artículo 414 del Decreto 2700/1991, la situación del principio in dubio pro reo ${ }^{113}$ no era extensible al contenido literal de la disposición anotada, de allí que estos eventos exigen la valoración específica por parte del juez, a fin de establecer si existía o no un daño antijurídico y por tanto, se encontraba demostrado el fundamento de imputación de la responsabilidad administrativa y la consecuente obligación resarcitoria. (Exp. 14530 y 14698, 2003). De modo que, en esta precisa situación, se robustece el título objetivo de imputación en tanto a la justicia penal le resultó imposible superar la duda razonable, razón por la cual el investigado no transgredió los bienes jurídicamente tutelados por el legislador.

En resumen, tiene lugar la declaratoria de responsabilidad de la administración cuando una persona es detenida preventivamente por decisión de autoridad, siendo posteriormente exonerada mediante sentencia absolutoria definitiva o su equivalente siempre que la absolución se base en que el hecho no existió o que el sindicado no lo cometió o en que el hecho que realizó no era punible. Aunado a ello es menester que el sindicado y

113 Cfr. Fallos de fecha 4 de diciembre de 2006, Exp. 13168; 2 de mayo de 2007, Exp. 15463; 27 de octubre de 2005, Exp. 15367; 5 de abril de 2008, Exp. 16819; 9 de junio de 2010, Exp. 19312 y; 7 de octubre de 2009, Exp. 17117. 
demás demandantes en el juicio de responsabilidad hayan padecido daño $\mathrm{y}$, que por parte del sindicado su detención no hubiese sido determinada conducta dolosa o gravemente culposa. (Exp. 13606, 2002)

Se debe tener en cuenta que la legalidad de la medida preventiva no escruta a través de las instituciones jurídico-penales sino en virtud del resultado del proceso penal. Puesto que si la medida fuera objeto de discusión, la situación jurídica pertinente sería la de falla del servicio debido a la ausencia o desacato de requisitos legales en la imposición de la medida. Mientras que, en el régimen objetivo la medida deviene injusta por la absolución posterior de la víctima, lo cual acredita la antijuridicidad del daño causado. Con base en esa distinción, la jurisprudencia administrativa extendió las premisas bajo las cuales tiene lugar la declaratoria de responsabilidad señalando incluso puede cuestionarse la medida preventiva en tanto:

$[\mathrm{H}]$ aya sido irrazonable porque el juicio sobre su procedencia según los parámetros de la ley no correspondan con la prueba que obraba en el proceso penal; o injustificada porque aunque se hubiera proferido inicialmente conforme a los parámetros legales, excedió el plazo razonable; o sea desproporcionada su duración en consideración al delito de que se trate; o porque, de acuerdo con las circunstancias específicas del asunto, al margen de la licitud o ilicitud de la decisión que le sirvió de fundamento, el particular que fue objeto de la medida privativa de la libertad no estaba en el deber jurídico de soportarla, conforme se hace evidente como consecuencia de una decisión definitiva de carácter absolutorio. En cada caso corresponderá al actor demostrar la injusticia, ilegalidad o irrazonabilidad de la medida. (Exp. 15348, 2005)

Adicionalmente, con independencia de los eventos anteriores, el Consejo de Estado amplió el espectro de protección al considerar que

[E]n los eventos en que se demuestra que la privación de la libertad fue injusta, -que lo será siempre que el proceso no termine con una sentencia condenatoria-, se está ante un daño imputable al Estado, que debe ser indemnizado con fundamento en lo dispuesto en el artículo 90 de la Constitución Política, así las razones de absolución o de preclusión de la investigación no obedezcan a ninguna de las causales previstas en el artículo 414 del antiguo C. de P. P. como causales de responsabilidad objetiva, o al in dubio pro reo. (Exp. 15980, 2008a) ${ }^{114}$.

114 En el caso citado, se imputó responsabilidad administrativa en razón a que el sindicado acreditó la existencia de una causal de justificación de responsabilidad penal. 
En el fallo de marras, igualmente se robustece la responsabilidad administrativa por privación injusta de la libertad en cuanto concurrieron situaciones objetivas y subjetivas en detrimento de los derechos y garantías individuales del sindicado, de allí que:

[Es] imputable al Estado el daño, consistente en la privación de la libertad, porque, de una parte, la absolución evidencia la injusticia de la medida de detención preventiva impuesta $\mathrm{y}$, de otra, se acreditó plenamente la falla del servicio en que incurrió la entidad pública demandada, que contribuyó a que la medida preventiva se prolongara indefinidamente. (Ibíd.)

Engrosa ésta línea de pensamiento, otros supuestos constitutivos de responsabilidad estatal, entre otros, la revocatoria de la medida de aseguramiento (Exp. 20569, 2011c); la falta de aplicación del principio de investigación integral (Exp. 15536, 2006a); la negativa a la concesión del beneficio de excarcelación (Exp. 15138, 2006b) y la recuperación de la libertad por ejercicio del hábeas corpus (Exp. 17174, 2008b).

Con todo, igualmente resulta notoria la falta de claridad del Consejo de Estado en cuanto resultan mezclándose las modalidades de falla del servicio junto a las causales del Decreto 2700 de 1991 en comunión con el artículo 68 de la Ley 270/1996. Sobre el particular, la Corporación señaló:

No siempre puede esperarse encajar la responsabilidad de la administración de justicia en el evento de privación de la libertad cuando la medida de aseguramiento consistente en detención se produzca por ser contraria a derecho (pese a su carácter sustancial), porque en la mayoría de los casos esta se encontrará conforme a la legalidad en la que se fundamenta, por lo que habrá que indagar si producido el daño antijurídico este se reputa de la decisión bien porque no hay elementos fácticos para determinar la existencia del hecho punible, o en otros eventos porque no existe prueba o esta permita inferir la duda a favor del sindicado o imputado, de tal manera que obre una valoración del in dubio pro reo. (Exp. 26679, 2011b).

Como puede verse, la jurisprudencia contencioso-administrativa ha depurado los contenidos y las modalidades sobre las cuales resulta exigible la indemnización de perjuicios como consecuencia de la privación injusta de la libertad. Ahora bien, el aspecto confuso de la ya mencionada situación jurisprudencial se refleja en la diversidad de criterios en casos que, si bien pudieran tratarse bajo criterios preestablecidos, resultan analizados de maneras distintas. Aspecto en el que tiene lugar la aplicación de los presupuestos descritos en el capítulo anterior en aras de lograr la unificación jurisprudencial a partir del reconocimiento de la misma diversidad de sentidos. 
En este punto, podría objetarse lo anterior si se considera que, recientemente la Sala Plena de lo Contencioso-Administrativo del Consejo de Estado (Exp. 21653,2011 a) en un intento de brindar claridad sobre la privación injusta de la libertad y su manejo jurisdiccional pareciera haber unificado las decisiones sobre ésta materia, lamentablemente dicha decisión, se limitó al compendio de argumentos de autoridad y recordación de posturas contenidas en fallos precedentes, al extremo que, tal y como lo consignara la opinión disidente del Consejero Enrique Gil Botero, la sentencia careciera por completo de una pretensión unificadora.

\section{PROPUESTA DE UNIFICACIÓN JURISPRUDENCIAL CONTENCIOSO-ADMINISTRATIVAEN TORNO A LA PRIVACIÓN INJUSTA DE LA LIBERTAD}

Finalmente, a manera de reiteración, se expone el diagrama diseñado al final de capítulo precedente con el fin de abordar las relaciones construidas en dicho esquema y su incidencia o capacidad de reducción de complejidad frente a las numerosas corrientes y razonamientos del Consejo de Estado frente a la privación injusta de la libertad:

\section{Criterios de formulación del precedente administrativo}

-Contenido de la sentencia de unificación-

$\underline{\text { I. Definición del concepto }}$ jurídico

a. Conveniencia

b. Emulación

c. Analogía

d. Simpatía

e.

En la primera columna, se persigue la proximidad o claridad en cuanto a la definición del concepto jurídico sobre el cual recaerá la decisión unificadora, para tal efecto, es necesario acoger alguna de las cuatro alternativas previstas siguiendo las explicaciones de FoucAult (2010): la conveniencia, la emulación, la analogía y la simpatía. 
Con miras a la aproximación semántica del concepto de privación injusta de la libertad, resulta necesario tener en cuenta que, como se vio, no existe unidad de criterio ni coherencia o ajuste en torno a dicha noción, por lo que resultaría insostenible acoger la opción de la conveniencia; de otra parte, las decisiones judiciales arriba citadas y esbozadas no ofrecen elementos que permitan inferir la imitación de institutos jurídicos similares nacionales o foráneos, por tanto, la emulación ha de descartarse. De igual manera tampoco resulta notorio que, el tratamiento de la privación injustificada de la libertad por parte de la jurisdicción contencioso-administrativa sea un subproducto jurídico o análogo, de hecho, se encontró que ésa institución tiene régimen propio y características identitarias autónomas e independientes de otras creaciones jurídicas.

En vista de lo anterior y dado que sólo resta una variable por agotar u acoger, según sea el caso, es pertinente recordar que el propósito principal de la primera columna de la estructura pretende la atribución del significado o, por lo menos, brindar la mayor claridad en cuanto al concepto bajo examen, de modo que sus elementos inherentes se preserven sin mutilaciones dada la variedad de títulos de imputación.

Por ello, es fundamental reconocer la diversidad de significados que dicha institución tiene dentro de la jurisprudencia administrativa, puesto que son aquellas modalidades las que terminan atribuyéndole sentido al concepto -privación injusta de la libertad-, en consecuencia, dicho propósito tiene la posibilidad de desarrollarse bajo la égida de la simpatía puesto que, conservando las diversas características del concepto, éste tiende a transformarse en uno de mayor envergadura, sin desnaturalizarlo.

En segundo lugar, es necesario acoplar el nuevo concepto creado por la simpatía con elementos estructurales que le permitan mantener su esencia. Así, se ofrecen cuatro posibilidades estructurales con consecuencias igualmente diversas: Unidad de la decisión, Lógica pragmática, Connotación y Denotación.

Como primera medida, debe descartarse sin lugar a dudas el criterio estructural de unidad de la decisión toda vez que, como pudo evidenciarse, la jurisprudencia contencioso-administrativa es altamente voluminosa, variable e incluso puede generar confusión sobre uno y otro título de imputación. De igual manera, dado que la situación de privación injusta deviene de particulares características modales, no es posible arroparlas bajo una misma posición jurisprudencial, por lo que ésta alternativa debe rechazarse. 
De otra parte, el criterio de la lógica pragmática carece de la capacidad de brindar coherencia entre el medio y el fin, puesto que no es posible unificar apreciaciones sobre el significado de privación injusta de la libertad cuando la materia de discusión se centra en el aspecto probatorio del proceso o la comprobación empírica de una restricción de éste talante; de tal suerte que esta opción resulta inaplicable.

En igual sentido, la connotación deviene improbable toda vez que no se pretende la inserción de nuevas características o elementos definitorios del concepto de privación injusta de la libertad, así como tampoco se persigue la discusión sobre las propiedades de ésta noción. En vista de lo anterior, la denotación sería la última alternativa, por tanto, es necesario comprobar si posee la entidad estructural necesaria para erigir sobre ella un armazón jurisprudencial.

Dado que el propósito radica en la consolidación del concepto y su posterior replicación con miras a minimizar la complejidad del sistema, la denotación desempeña el rol de preservar el alcance del concepto y de hacerlo vinculante sobre situaciones posteriores en las que el concepto denotado se involucre, por tanto, ésta categoría contribuye al objetivo descrito.

Por último, el concepto y su significado así como el pilar sobre el cual se erigirán la unificación jurisprudencial, debe cumplir una función coherente con el propósito de ordenación, de modo que habrá de seleccionarse la opción más apropiada frente a la dicotomía que plantean las finalidades de asentamiento $y$ previsión. En concordancia con lo expuesto, es necesario precisar el propósito del establecimiento del concepto - privación injusta de la libertad-y las situaciones cobijadas por éste-denotación del concepto-, de manera que la selección efectuada resulte consecuente con dicho cometido.

Teniendo en cuenta el objetivo de la estructura, no es posible acoger la función de previsión por cuanto lo anhelado en este momento no es la repetición ni mucho menos la consolidación de una posición que no ha sido prefijada, puesto que de elegirse ésta alternativa, no podrían superarse las múltiples situaciones conceptuales presentes en la jurisprudencia contencioso-administrativa del mismo modo que persistiría la proliferación de decisiones sobre el concepto anotado, por lo que los fines de unificación serían engañosos. De lo anterior, se encuentra que la finalidad no es distinta a la superación de la complejidad derivada del número de decisiones sobre un mismo asunto, por ende, lo deseable y consecuente sería el asentamiento de una posición jurídica conglobante construida a partir de la diversidad de criterios a través de la simpatía. 
En conclusión, para los efectos de la presente investigación, el precedente Contencioso-Administrativo respecto de la privación injusta de la libertad se desarrollaría al amparo de la estructura que sigue:

\section{Privación injusta de la libertad}

\begin{tabular}{|c|c|c|c|}
\hline I. Definición del concepto & Estructura & del & Función \\
\hline jurídico & precedente & & decisión \\
\hline Simpatía & Denotación & & Asentamiento \\
\hline
\end{tabular}

\section{CONCLUSIONES}

La metodología presentada se planteó como una respuesta epistemológica aplicada a un problema judicial cuyos efectos reflejan las variables prácticas en el reconocimiento de los derechos, la estabilidad del sistema jurídico y la percepción del escenario local en un ambiente impregnado de globalización en todos los ámbitos de la vida del Estado.

En esta medida, se hace necesario implementar mecanismos que controlen o aminoren el exceso de fluctuaciones conceptuales respecto de las decisiones judiciales estructura que posibilite la unificación de la jurisprudencia contencioso-administrativa a través de las relaciones entre derecho y lenguaje referidas a la adopción de significados para los conceptos jurídicos, de suerte que a partir de dicho elemento sea posible establecer el alcance de las decisiones judiciales con miras a brindar parámetros que precisen la unidad de las decisiones o el marco dentro del cual los conceptos jurídicos se relacionan con las controversias sometidas al estudio judicial y, con ello, procurar el establecimiento y posterior consolidación de decisiones inequívocas, en términos de proyectarse en el tiempo, dotadas de univocidad frente al contenido, significado y contexto de los conceptos jurídicos relacionados en la solución de las disputas deferidas al conocimiento de la jurisdicción de lo contencioso-administrativo.

Es de anotar que la textura abierta y la discrecionalidad judicial han ocasionado un grave daño a la forma en que se asumen y profieren las decisiones judiciales, habida cuenta que, la falta de metodología y estructura en la tarea unificadora ha dado permanencia al fenómeno de la complejidad sin que, a la fecha, se encuentre un mecanismo epistemológico que permita abarcar en mayor medida la heterogeneidad conceptual y simplificarla a través de herramientas funcionales. 
Ésta propuesta metodológica partió del reconocimiento de la diversidad semántica de los conceptos jurídicos, de modo que a través del proceso de sistematización y estructura sea posible reagruparlos con fines epistemológicos que conduzcan a determinar qué parte del significado jurídico es aplicable o rector del caso concreto y qué parte del mismo es incompatible, o corresponde a otra situación jurídica concreta a pesar de regirse bajo un mismo término.

No obstante lo anterior, la estructura diseñada no da cabida al sostenimiento y exposición de un esquema rígido e inmodificable toda vez que no puede actuarse de manera cerrada o mutilante frente a los diversos fenómenos y tendencias que inciden en la comprensión de los conceptos jurídicos, su semántica, la metodología judicial y la asunción de posiciones jurídicas con efectos hacia el futuro.

Bajo estas consideraciones, la investigación diseñó los siguientes elementos:

i. Definición del concepto jurídico: A través de esta categoría se pretendió explicar la forma en que suceden los procesos de atribución de significado y sentido a las expresiones lingüísticas, las cuales, como es de suponerse, se encuentran igualmente al interior del ordenamiento jurídico. Dicho proceso de atribución semántica tiene como base epistemológica las formas de similitud descritas en la obra de FOUCAULT: la conveniencia, la emulación, la analogía y la simpatía.

La categoría adoptada, se corresponde con los fenómenos judiciales existentes a través de decisiones jurídicas concretas, de allí que los conceptos preformados sean estudiados con el fin de adaptarse a la situación fáctica (conveniencia); o porque un tema puede encuadrarse sobre otro ya desarrollado (emulación), también porque la similitud del caso objeto de estudio tiene los mismos presupuestos que un concepto parecido (analogía) o finalmente porque se puede llegar a cambiar la noción tratada y mejorar el concepto (simpatía). No obstante, en esta última subcategoría puede existir la alternativa de aislamiento frente a casos anteriores, en cuyo caso la simpatía es ejercida por conducto de su antítesis, la antipatía.

A partir de las similitudes descritas, es necesario que, con el fin de avanzar en el proceso de formulación de una decisión unificadora, se escoja sólo una de las opciones presentadas, de allí que no sea posible mezclar o interpretar con laxitud las subcategorías involucradas.

Una vez efectuada la selección, se cumple el primer requisito de la unificación, es decir, describir el entorno semántico de la acepción jurídica 
sub lite y, consecuentemente sea posible determinar cómo el significado del concepto incidirá en la estructuración del precedente.

ii) Estructura del precedente: En este punto, el objeto lo constituye la finalidad de estabilizar o reducir las fluctuaciones sobre el significado del concepto, garantizando la seguridad jurídica a través de la gestión del riesgo en la interpretación del mismo.

Se involucran las subcategorías de unidad de la decisión, lógica pragmática, connotación y denotación, las cuales facilitan el reconocimiento por caracteres identitarios de las razones jurídicas de las salas de decisión. Aquí, los límites del precedente tienden a la fijación del alcance del tema desde el concepto jurídico lato sensu hasta la apreciación in concreto del juez ContenciosoAdministrativo de modo que las posturas jurídicas y sus elementos de soporte se concreten en elementos estructurales claros que no den lugar a variaciones injustificadas, arbitrarias o coyunturales de la jurisprudencia.

Bajo ésta categoría es preciso establecer cuatro situaciones: Si es preciso cesar la continua creación jurisprudencial sobre el mismo tema, es decir, si existen argumentos generalmente aceptados y generalizados en punto de determinada discusión jurídica (unidad de las decisiones) o; si el contenido probatorio del caso concreto puede modificar la razón de la decisión, de suerte que el fallo tendrá elementos técnico-probatorios con incidencia excepcional sobre la materia discutida (lógica pragmática) o; si los elementos conceptuales del problema jurídico pueden permanecer en cierta forma pétreos, delimitando el alcance del concepto (connotación) o; si como última medida eventuales decisiones futuras contemplan la existencia de elementos adicionales o restrictivos pese a que el contenido del problema jurídico se asemeje a uno previamente resuelto de suerte que se fije el alcance de los conceptos desarrollados hacia futuras decisiones, esto es, reconociendo ejemplos y adhiriendo la situación a la forma jurídica predeterminada o, dicho de otro modo, estableciendo a qué situaciones le es aplicable dicho precedente.

Al igual que como aconteció con las subordinadas de la categoría Definición del concepto jurídico, los subcriterios enunciados operan de forma excluyente entre sí.

iii) Función de la decisión: Finalmente, la última casilla denominada función de la decisión se proyecta según el telos de la situación, es decir, qué se pretende con la decisión judicial a través de las funciones de asentamiento o previsión, igualmente antitéticas. 
En lo que corresponde a la primera de éstas (asentamiento), su finalidad consiste en elaborar un contenido judicial pleno y preciso que le permita a la sala de decisión fijar una posición sobre determinada cuestión jurídica, situación que permitirá fijar al interior de otras entidades del Estado criterios para demarcar sus actuaciones y les permitan actuar de manera previsiva frente a eventos constitutivos de riesgo presupuestal contingente derivado de condenas en sede contencioso-administrativa. De igual manera, éste evento le permite al ciudadano comprender con cierto asomo de claridad, bajo qué supuestos es posible invocar la extensión de efectos de las sentencias de las jurisdicción contencioso-administrativa ante las autoridades. De suerte que tanto para los poderes públicos como para los particulares sea inteligible el contenido y efectos del precedente.

En segundo lugar, en lo que respecta a la función de previsión, ésta tiene lugar en el esclarecimiento o anticipación a eventualidades no previstas o no falladas con anterioridad. Con ello, las expectativas normativas consiguen una protección desde las propias sentencias a partir de efectos generales bajo pautas pre-examinadas por la jurisdicción contencioso-administrativa, de modo que el mecanismo de extensión jurisprudencial actúe como una forma de verificación de los presupuestos en que determinado derecho reclamado ha de ser reconocido.

En el tercer capítulo, la metodología diseñada se aplicó a una situación jurídica concreta con el fin de determinar la falseabilidad de la hipótesis planteada. Encontrándose que, frente al tema seleccionado (privación injusta de la libertad), los elementos conceptuales y estructurales de la diseño metodológico satisficieron los requisitos de comprobación a través de cada una de las subcategorías integrantes de los criterios de unificación jurisprudencial, estableciéndose la funcionalidad de la estructura propuesta.

Por último, es preciso anotar que, como se señaló en líneas precedentes, el modelo-propuesta de unificación jurisprudencial materia de ésta investigación, no puede considerarse como una herramienta cerrada frente a la praxis judicial; por el contrario, pretende realizar un aporte académico encaminado a la solución de un problema de la sociedad colombiana.

\section{BIBLIOGRAFÍA}

Ibáñez, P. A, (2005). Garantismo: Una teoría crítica de la jurisdicción. En: M. C. Salazar, Garantismo. Madrid: Trotta.

Austin, J. (2002). El objeto de la jurisprudencia. (J. De Páramo Argüelles, Trad.) Madrid: Centro de Estudios Políticos y Constitucionales. 
Becerra, A. (2011). "La jurisprudencia en el Nuevo Código". En: Consejo de Estado, Seminario Internacional de presentación del Nuevo Código de Procedimiento Administrativo y de lo Contencioso-administrativo. Bogotá: Imprenta Nacional de Colombia.

Beck, U. (1998). ¿Qué es la Globalización? (1 ed.). (B. Moreno Carrillo, \& M. Borrás Borrás, Trads.) Barcelona: Paidós.

—. (2002). La sociedad del riesgo global. (J. Alborés Rey, Trad.) Madrid: Siglo veintiuno de España editores.

Botero, J. (9 de mayo de 2014). Extravíos del NeoConstitucionalismo. Recuperado el junio de 2014, de Fasecolda: http://www.fasecolda.com/files/6613/9991/2373/ memoriaJHBOTEROcds2w.pdf

Comanducci, P. (2007). Modelos e interpretación de la Constitución. En M. Carbonell, Teoría del Neoconstitucionalismo (M. Ferrer Muñoz, Trad.). Madrid: Trotta.

Consejo de Estado, Sala de Consulta y Servicio Civil. (2014). Las sentencias de unificación y el mecanismo de extensión de jurisprudencia. Bogotá: Imprenta Nacional de Colombia.

Ferrajoli, L. (2008). Democracia y Garantismo. (M. Carbonell, Ed., P. Andrés Ibáñez, C. Courtis, G. Pisarello, \& M. Carbonell, Trads.) Madrid: Trotta.

Foucault, M. (2010). Las palabras y las cosas. (E. C. Frost, Trad.) México, D.F.: Siglo xxi Editores, s.a. de c.v.

Gadamer, H. G. (2007a). El problema de la conciencia histórica. (A. D. Moratalla, Trad.) Madrid: Tecnos.

—. (2007b). Verdad y Método I. (A. Agud Aparicio, \& R. De Agapito, Trads.) Salamanca: Sígueme.

—. (2007c). Verdad y Método II. (A. Agud Aparicio, \& R. De Agapito, Trads.) Salamanca: Sígueme.

Gascón, M. (2005). "La Teoría General del Garantismo: Rasgos principales”. En M. Carbonell \& P. Salazar, Garantismo: Estudios sobre el pensamiento jurídico de Luigi Ferrajoli. Madrid: Trotta.

Giraldo, A. L. (1993). Argumentos y falacias. Santiago de Cali: Universidad del Valle Facultad de humanidades colección textos académicos.

González, R., \& Hines, C. (2006). Reflexiones para el Recurso de Casación en el proceso contencioso administrativo. San José: Instituto de Investigaciones Jurídicas.

Guastini, R. (2007). “Sobre el concepto de Constitución”. En Carbonell, M. Teoría del Neoconstitucionalismo. Madrid: Trotta. 
Hart, H. L. (1998). El concepto de derecho. (G. R. Carrió, Trad.) Buenos Aires: Abeledo Perrot.

Herrera, H. (2013). Reflexiones sobre el desarrollo de los mecanismos alternativos de solución de controversias. En CEJ, Aproximación a la historia de una década de transformaciones en la justicia colombiana. Bogotá: Corporación Excelencia en la Justicia.

Hoyos, R. (2006). "Responsabilidad del Estado por privación injusta de la libertad". Prolegómenos: Derechos y valores , IX (17).

Kelsen, H. (1998). Teoría Pura del Derecho (10 ed.). (R. Vernengo, Trad.) México D.F.: Porrúa.

López, D. E. (2009). “¿Por qué hablar de una "Teoría impura del derecho” para América Latina?”. En: D. Bonilla Maldonado. Teoría del Derecho y trasplantes jurídicos. Bogotá: Siglo del Hombre Editores - Universidad de Los Andes.

Luhmann, N. (2005). El derecho de la sociedad. (c. 1. Javier Torres Nafarrete, Trad.) México: Herder.

—. (2005a). El derecho de la sociedad. (J. Torres Navarrete, Trad.) México: Herder.

—. (2005b). Organización y decisión. Autopoiesis, acción y entendimiento comunicativo. (D. R. Mansilla, Trad.) Barcelona: Anthropos.

—. (2005c). Poder. (d. 1. Lúz Mónica Talboth, Trad.) Barcelona: Anthropos.

Manassero, M. d. (2001). De la argumentación al derecho razonable, un estudio sobre Chaïm Perelman. Navarra: Ediciones Universidad de Navarra, S.A.

Moreno Durán, Á., \& Ramírez, J. (2011). Sociología del campo jurídico en Colombia. Bogotá: Universidad Santo Tomás.

Morin, E. (2007). Introducción al pensamiento complejo. (M. Pakman, Trad.) Barcelona: Gedisa .

Popper, K. R. (2002). Búsqueda sin término. (C. G. Trevijano, Trad.) Madrid: Tecnos.

Posner, R. A. (2011). Análisis económico del derecho. (C. M. Ravina, Trad.) Bogotá: Siglo del hombre editores.

Rojas Betancourth, D. (2012). Extensión de las sentencias de unificación de la Jurisprudencia. En Consejo de Estado, Instituciones del Derecho Administrativo en el nuevo Código: Una mirada a la luz de la Ley 1437 de 2011. Bogotá.

Ross, A. (2007). Teoría de las fuentes del derecho (una contribución a la teoría del derecho positivo sobre la base de investigaciones histórico-dogmáticas). (A. D. José Luis Muñoz de Baena Simón, Trad.) Madrid: Centro de estudios políticos y constitucionales. 
Ruíz, M. Á. (2012). Consideraciones generales sobre el recurso de casación en el orden jurisdiccional contencioso-administrativo: Especial referencia a la fase de admisión. Foro, Nueva Época, 15, 249-260.

Salguero, M. (2002). Argumentación jurídica por analogía. Barcelona: Marcial Pons, ediciones jurídicas y sociales S.A.

Santofimio, J. (2010). La fuerza de los precedentes administrativos en el sistema jurídico del Derecho positivo colombiano. Bogotá: Universidad Externado de Colombia.

Sartori, G. (2010). La Política (3 ed.). (M. Lara, Trad.) México D.F: Fondo de Cultura Económica.

Stiglitz, J. (2004). El maestar en la globalización. (C. Rodríguez Braun, Trad.) Bogotá: Taurus.

Teubner, G. (2005). El derecho como sistema autopoiético de la sociedad global. (C. Gómez-Jara Díez, Ed.) Bogotá: Universidad Externado de Colombia.

Torres, L. (2002). Reflexiones sobre la congestión judicial en la jurisdicción contenciosa administrativa colombiana. Revista de Derecho Público (14).

\section{PROVIDENCIAS JUDICIALES}

Exp. 7058 (Consejo de Estado de Colombia 1 de octubre de 1992).

Exp. 9734 (Consejo de Estado de Colombia 30 de junio de 1994a).

Exp. 8666 (Consejo de Estado de Colombia 25 de julio de 1994b).

Exp. 9391 (Consejo de Estado de Colombia 15 de septiembre de 1994c).

Exp. 10056 (Consejo de Estado de Colombia 17 de noviembre de 1995).

Exp. 10299 (Consejo de Estado de Colombia 12 de diciembre de 1996).

Exp. 11754 (Consejo de Estado de Colombia 18 de septiembre de 1997).

Exp. 13606 (Consejo de Estado de Colombia 4 de abril de 2002).

Exp. 14530 y 14698 (Consejo de Estado de Colombia 27 de noviembre de 2003).

Exp. 15348 (Consejo de Estado de Colombia 28 de abril de 2005).

Exp. 15536 (Consejo de Estado de Colombia 1 de marzo de 2006a).

Exp. 15138 (Consejo de Estado de Colombia 1 de marzo de 2006b).

Exp. 13168 (Consejo de Estado de Colombia 4 de diciembre de 2006c).

Exp. 15463 (Consejo de Estado de Colombia 2 de mayo de 2007).

Exp. 34985 (Consejo de Estado de Colombia 9 de septiembre de 2008).

Exp. 15980 (Consejo de Estado de Colombia 15 de febrero de 2008a). 
Exp. 17174 (Consejo de Estado de Colombia 16 de julio de 2008b).

Exp. 19312 (Consejo de Estado de Colombia 9 de junio de 2010).

Exp. 21653 (Consejo de Estado de Colombia 6 de abril de 2011a).

Exp. 26679 (Consejo de Estado de Colombia 13 de abril de 2011b).

Exp. 20569, Consejo de Estado de Colombia (12 de mayo de 2011c).

Sentencia C-037 (Corte Constitucional de Colombia 5 de febrero de 1996).

Sentencia No. 00031 (Corte Suprema de Justicia de Costa Rica - Sala Primera 20 de mayo de 1994).

STC 37/2012 (Tribunal Constitucional Español 19 de marzo de 2012).

STS 309/2004 (Tribunal Supremo Español - Sala de lo Contencioso Administrativo 26 de enero de 2004).

STS 7222/2005 (Tribunal Supremo Español - Sala de lo Contencioso Administrativo 13 de diciembre de 2005). 


\title{
LA CONSTITUCIÓN Y EL CONSTITUCIONALISMO: SU DIVERSIDAD CONCEPTUAL, HISTÓRICA Y SOCIAL*
}

\author{
AndRÉS Abel RodríGueZ Villabona*
}

\section{INTRODUCCIÓN}

Con el término constitución se puede hacer referencia a tres tipos de realidades. Uno puede decir, por ejemplo, que un país tiene una constitución fuerte, de manera similar a como decimos que una persona tiene una constitución resistente o robusta. En este caso hacemos referencia a una estructura o a una esencia fáctica que tendrían las sociedades como la tienen los objetos o los seres vivos. Los antiguos griegos y los pensadores de la Edad Media concebían las constituciones en este sentido. También es posible concebir la constitución como la consagración del modelo de sociedad al que un país quiere llegar algún día. Los jacobinos en Francia y algunos líderes políticos latinoamericanos del siglo XIX veían las constituciones de esta manera. Podemos igualmente decir que la constitución es una norma o ley fundamental que regula el ejercicio del poder político. En este sentido una constitución se parece a un código básico de derecho público. ¿Son estos significados complementarios o excluyentes?; si son complementarios, ¿qué relación existe entre ellos?, y si son excluyentes ¿hay alguno de ellos que se imponga sobre los demás? Para responder a estas preguntas conviene detenerse sucintamente en cada una de dichas concepciones, que están en el centro de lo que se ha dado en llamar constitucionalismo.

\footnotetext{
* El presente capítulo de libro es producto del proyecto de investigación "Grandes debates del derecho constitucional contemporáneo", el cual se constituye en uno de los proyectos de investigación institucionales de la Universidad Santo Tomás (sede Bogotá).

** Doctor en Derecho Público de la Universidad Grenoble-Alpes (Francia); magister (DEA) en Filosofía del Derecho de la Universidad Panthéon-Assas París II; magister (DEA) en Derecho Público de la Universidad Panthéon-Sorbonne París I. Docente e Investigador de la Universidad Nacional y de la Universidad Santo Tomas (Sede Bogotá).Correo Electrónico: andresabelrodriguez@hotmail.com
} 
Aunque tienen referentes distintos no hay duda de que los dos términos -constitución y constitucionalismo- están profundamente relacionados, siendo el primero el origen del segundo. También es evidente que se le han atribuido diversos significados, lo cual explica la complejidad del debate entre las diversas concepciones sobre la constitución. Aunque el propósito central de este trabajo es presentar algunas de esas concepciones, es importante detenernos también en los diferentes usos del término constitución que enmarcan aquel debate y le dan su sentido lingüístico.

\section{EL TÉRMINO «CONSTITUCIÓN»}

La aplicación del término «constitución», que proviene del latín constitutǐo, al ámbito del gobierno de las sociedades humanas inicialmente se hizo en dos sentidos: por un lado, a partir del significado que se le asignaba en la medicina y en las ciencias naturales para describir el estado u orden de un cuerpo en su existencia biológica, con el término constitución se apuntaba también a la situación del cuerpo político, esto es, a la estructura de poder de una comunidad; por otro lado, este término se usaba en el ámbito jurídico para hacer referencia a algunas normas importantes por su origen pero que no se referían necesariamente al ejercicio del poder político (Beaud, 2003, p. 133; Stourzh, 2007, p. 85). Este último era el sentido que se le atribuía en las compilaciones del derecho romano justinianeo ${ }^{115}$ y que se mantuvo durante toda la Edad Media y hasta bien entrado el siglo XVII.

115 Así, en uno de los apartados más conocidos del Digesto (una de las cuatro compilaciones que, varios siglos después, en 1583, el jurista Dionisio Godofredo publicó con título de Corpus Iuris Civilis), se cita la doctrina de Ulpiano según la cual «lo que plugo [complace] al Príncipe tiene vigor de ley; como quiera que por la ley Regia que se promulgó acerca de su autoridad, el pueblo confiriese a él y para él todo su imperio y potestad. Así pues, lo que el Emperador estatuyó por carta y resolución de un memorial, o conociendo en causa decretó, o de plano decidió, o preceptuó por edicto, consta que es ley; estas son las que vulgarmente llamamos constituciones» (Digesto, 1. 4. 1.; García, 1889, pp. 212-213). Por lo demás, antes de las compilaciones justinianeas, para hacer referencia a los mos maiorum de la Roma antigua, expresión latina que designaba las costumbres de los ancestros, desde tiempo atrás se había venido utilizando la denominación «constitución romana». Con todo, estos no eran más que un conjunto de directivas y principios de carácter consuetudinario sobre las formas de organización de las instituciones, que se trasmitían oralmente y que no estaban contenidas en ningún documento. Esta «constitución» evolucionó y de una monárquica se pasó al final del siglo sexto a. C. a una republicana y en 27 a. C. a una de carácter imperial. El último cambió importante se produjo en 300 d. C. cuando se dio paso a la Constitución del 
Fue así como bajo el Sacro Imperio Romano Germánico se entendía por constituťo la ley promulgada por el emperador, independientemente de su objeto (por ejemplo, la Constitutio Criminalis Carolina de 1532), mientras que las normas que regulaban el ejercicio del poder se denominaban leges fundamentales (Grimm, 2006c, p. 108) ${ }^{116}$. En un sentido similar se usaba la expresión «constituciones», en plural, para nombrar al conjunto de textos pontificales o monásticos ${ }^{117}$. Tomando la significación romano-germánica, durante la Baja Edad Media, en Francia y en varios otros reinos de Europa continental, la palabra constitution también fue empleada para designar las medidas legislativas adoptadas por los monarcas (Guzmán Brito, 2002, p. $294)^{118}$. Con todo, a partir del siglo XIV en aquel país se comenzó a hacer referencia con ese término, así como con el de loi, a los principios que habían surgido de la costumbre y que dotaban a la monarquía francesa de un orden que aseguraba su estabilidad, principalmente fijando las condiciones de la sucesión al trono (entre ellos está, por ejemplo, los de la «ley sálica», que excluía a las mujeres de la corona). Posteriormente, después del siglo $\mathrm{XVI}$, se impuso la expresión lois fondamentales para designar las normas que establecían el régimen de la monarquía francesa (Bastid, 1985, p. 13; Favoreu, 1999, p. 22; Rigaudière, 1997, pp. 96-100; Verdú, 1994, p. 20).

En Inglaterra, por su parte, la palabra constitution también tenía las dos acepciones que ya se indicaron: por un lado, significaba ley formalmente promulgada, aunque en este sentido fue sustituida por la palabra statute, al tiempo que la organización del poder público vino a denominarse form of government; por otro lado, con la misma se indicaba también el estado o la situación política real de una sociedad. Con todo, desde el siglo XVII se dio paulatinamente el giro hacia el sentido moderno del término (Stourzh,

Bajo Imperio Romano (véase al respecto: Lintott, 1999, pp. 27-39; Mousourakis, 2003, pp. 1-6).

116 En lengua alemana se da la peculiaridad de que además del término Konstitution existe también el de Verfassung, que pueden considerarse sinónimos, aunque inicialmente el primero de ellos hacía referencia más al aspecto jurídico, a la regulación jurídica, mientras que el segundo servía sobre todo para describir un estado real de cosas (Dippel, 2009, p. 14).

117 Así, reciben el nombre de «constituciones apostólicas» las bulas papales que contienen alguna decisión o mandato, así como las colecciones de reglas canónicas atribuidas a los apóstoles.

118 Además de constitution, estas medidas recibían otros nombres: en Francia los de loi, édit y ordonnance; en España, pragmática y ordenamiento; en Alemania Ordung; en Italia, capitolo, prammatica y editto, y en Inglaterra, statute (Guzmán Brito, 2002, p. 293). 
1977, pp. 304-313) pen el que se mantiene su vínculo con la política pero se afirma paulatinamente su carácter jurídico-normativo. Aunque en esta época se hablaba aún de «la constitución del gobierno del reino», del body politic, como cuando se hace referencia a la constitución del cuerpo humano, empezó a surgir un significado político-normativo del término, concibiéndose como el conjunto de principios fundamentales que rigen el gobierno de la sociedad $\mathrm{y}$, al mismo tiempo, como el acto fundacional de la misma. Por ejemplo, en el debate que se produjo en 1610 en la Cámara de los Comunes en contra de las Impositions del rey Jacabo I (1566-1625), James Whitelocke (15701632) afirmó que éstas eran "contrarias al marco y constitución naturales de la política de este reino (natural frame and constitution of the policy of this kingdom), que es ius publicum regni, y por ende subvierten las leyes fundamentales del reino e inducen una nueva forma de Estado y de gobierno» ${ }^{119}$. Al mismo tiempo también comenzó a utilizarse la expresión fundamental constitutions con el mismo significado de fundamental laws, dándose a constitution el significado de ley fundacional ${ }^{120}$. Ahora bien, «no fue sino hasta la Revolución gloriosa que el término "constitución" se usó en un acto de Estado de trascendencia» (Stourzh, 2007, p. 92): en la primera de dos las resoluciones aprobadas por los Comunes el 28 y 29 de enero de 1689 , en las que se dispone que el rey Jacobo II abdicó al trono por haber «intentado subvertir la Constitución del reino (...)».

Aunque la expresión fundamental constitutions fue muy poco utilizada después de la Revolución gloriosa, en las colonias inglesas de Norteamérica iba a tener un destacable destino, ya que dos de las más importantes cartas coloniales la incorporaron en su título: Fundamental Constitutions of Carolina de 1669, en cuya redacción participó John Locke (1632-1704), y Fundamental Constitutions for the Province of East New Jersey in America de 1683. En esta misma línea William Penn (1644-1718) tituló Fundamental Constitutions of Pennsilvania su proyecto de carta para esta colonia. Años después, durante la época de la independencia, se retomó el sentido fundacional que en las cartas coloniales tenía dicha expresión, que servía para hacer referencia al acto de establecimiento de una sociedad. Es más, como

119 El texto del discurso de White Locke sobre las Impositions se reproduce en la compilación de J. P. Kenyon (1966, pp. 60-61).

120 Por ejemplo, en un panfleto antirrealista publicado bajo el título The Case of Shipmoney briefly discoursed en 1640, Henry Parker (1604-1652) asegura que «por las verdaderas constituciones fundamentales (true fundamental constitutions) de Inglaterra, el vínculo entre el Rey y los Súbditos siempre se mantiene» (citado en Stourzh, 2007, p. 93). 
este acto se concretaba en un documento solemne en el que se proclamaban los derechos de los individuos y se establecía la forma de gobierno, no sólo el acto sino también el documento se denominó constitution. Esto explica que el carácter jurídico-político de la constitución, que configura la concepción moderna de la misma, surja del conflicto constitucional en torno a algunas leyes del parlamento británico que se consideraban inconstitucionales por parte de las élites políticas de las colonias. Para oponerse a estas leyes recurrieron a la idea de los derechos naturales e intangibles, aunque estos derechos ahora aparecen plasmados en una ley suprema, en una constitución escrita con fuerza jurídica y, por ende, obligatoria. Así pues, «esta nueva significación de la palabra refleja un cambio capital: la "juridificación" de la constitución que nace de la unión del término constitución con la expresión de leyes fundamentales» (Beaud, 2009, p. 24). Con todo, el hecho de que ahora ese término aparezca en singular y no en plural no es un simple ajuste sintáctico, puesto que esta sustitución del «plural aditivo» por el «singular colectivo» refleja una reducción de lo real a un «nivel superior de abstracción» (Koselleck, 2007, p. 370) ${ }^{121}$. Así se hizo, por ejemplo, en la Constitution, or Frame of Government de Virginia del 29 de junio de 1776, en la Constitution, or System of Government de Delaware del 27 de agosto de 1776, en la Constitution of the Commowealth of Pennsylvania del 28 de septiembre de 1776, en la Constitution or Form of Government de Maryland del 11 noviembre de 1776 y en la Constitution or Frame of Government de Carolina del Norte del 18 de diciembre de 1776. En fin, cuando en 1787 se logró establecer la unidad de las antiguas colonias bajo un gobierno federal, el documento que lo instituyó, siguiendo el uso que se había consolidado, recibió el nombre de Constitution for the United States of America. Ahora bien, en esta ocasión no se consideró necesario complementar el título con expresiones como «forma de gobierno» o «sistema de gobierno», ya que bastaba la palabra «constitución» para significar el carácter jurídico-político

121 Este mismo autor destaca algunas implicaciones de esta nueva unidad que se manifiesta en la expresión «constitución», en singular. Entre ellas está, por ejemplo, que el concepto de separación de poderes puede plantearse en la medida en que hay una unidad, la constitución, que hace posible la separación de poderes en su pluralidad (Koselleck, 2007, p. 381). A esas implicaciones O. Beaud añade el hecho de que la palabra constitución «ya no tiene necesidad de complemento de nombre o de adjetivo. En efecto, si antes había siempre que precisar a lo que se refería la constitución -por ejemplo, la "constitución del Estado" o incluso la "constitución del gobierno"-, con posterioridad la palabra "constitución" se comprende sin adjetivo calificativo o sin complemento de nombre» (Beaud, 2009, p. 4). 
del documento. Es más, durante este periodo la palabra constitución no se limitó a servir de título a un documento escrito, pues con la misma se aludió también a un conjunto de normas que fundamentan la competencia para elaborar las demás normas jurídicas y que, por ende, son superiores a éstas y definen su vigencia. Esta es la concepción que el presidente de la Corte Suprema John Marshall plasmó en la más conocida decisión judicial de la historia estadounidense, la sentencia Marbury contra Madison: «ciertamente, todos aquellos que han elaborado constituciones escritas las consideran la ley fundamental y suprema de la nación y, consecuentemente, la teoría de cualquier gobierno de este tipo debe ser que una ley repugnante a la Constitución es nula».

La modernización del término «constitución» se completó durante la Revolución francesa. Antes de este evento, sin embargo, en ese país ya se había iniciado este proceso, que tuvo un protagonista principal, el barón de Montesquieu (1689-1755). A pesar de que su obra más célebre, De l'esprit des lois (1748), no contiene «ni una teoría de la constitución ni una verdadera definición de la noción de constitución, (...) en realidad innova desde un punto de vista semántico al titular el libro XI del Espíritu de las leyes: "De las leyes que dan origen a la libertad política en su relación con la constitución". Es aquí que la palabra adquiere un sentido político convirtiéndose en el equivalente de la politeia griega, al tiempo que expresa un destacable giro conceptual pues pasa a asociarse a la idea de libertad política y de división de poderes» (Beaud, 2009, pp. 10-11). Con este punto de partida, los líderes revolucionarios no la utilizaron para designar cualquier forma de gobierno sino para identificar aquella que sometida a límites jurídicos garantizaba los derechos de los ciudadanos y se basaba en la separación de poderes. Entre los numerosos escritos de la época a este respecto se destacan los de Emmanuel Sièyes (1748-1836) quien en un discurso de 1789 titulado Preliminar de la constitución afirmó que «el verdadero sentido de la palabra Constitución» «abarca la formación y la organización interiores de los diferentes poderes públicos (...) es relativa al conjunto y a la separación de los poderes públicos», los cuales «están todos sujetos a leyes, reglas y formas que no pueden cambiar a su antojo»» porque «tal y como no pudieron constituirse a sí mismos, tampoco pueden cambiar su Constitución» (Sièyes, 1993, p. 183). Como ocurría en Estados Unidos, Sièyes se servía del término constitución para aludir tanto a una forma de gobierno y al acto de su establecimiento como al documento que establecía a través de prescripciones los límites jurídicos al ejercicio del 
poder. De esta manera fusionó dos acepciones de constitución: la clásica, que la concibe como la organización de los poderes, y la moderna, que la concibe como una ley fundamental que impone límites a estos poderes ${ }^{122}$. Estos fueron los presupuestos del debate que se dio en la Asamblea Nacional sobre si Francia tenía o no una constitución. Se impuso la tendencia que daba una respuesta negativa a esta cuestión, razón por la cual el artículo 16 de la Declaración de los Derechos del Hombre y del Ciudadano de 1789 dispuso que «toda sociedad en la que no esté asegurada la garantía de los derechos ni determinada la separación de los poderes, no tiene constitución».

Podría pensarse que en el mundo hispano el uso del término constitución en su sentido moderno se desarrolló después de que se había consolidado en Estados Unidos y en Francia. Para confirmar esta hipótesis es posible aducir el inicio en 1810 de diversos procesos constitucionales, tanto en España como en América, con los que se pretendía responder a la crisis de la monarquía española desencadenada a partir de 1807 y 1808 en razón a su sometimiento al imperio francés en cabeza de Bonaparte (Artola, 1959, t. I, p. 195-202). Producto de aquellos procesos son los diversos textos constitucionales que se aprobaron en América (declaraciones de independencia y constituciones propiamente dichas), así como los que se promulgaron en la península: la constitución de Bayona de 1808, con la que se oficializó el ascenso al trono español del hermano de Napoleón, y la constitución de Cádiz de 1812, «la anti-carta de la España no napoleónica en contra del estatuto otorgado de Bayona» (Marquardt, 2009, p. 35). No obstante, como lo señala J. M. Portillo, «conviene no descartar una cultura de la constitución que venía abriéndose paso desde las décadas finales del siglo anterior». Con esto no se hace referencia «a usos de este término

122 Como lo explica O. Beaud, Sièyes «de una parte, capta la dimensión organizacional de la constitución a través de la metáfora orgánica del “cuerpo" político. De esta manera, puede utilizar el recurso a esta acepción médico-biológica de la constitución que probablemente pide prestado a Rousseau y a Montesquieu, e indirectamente a la tradición de pensamiento político que jamás perdió de vista la "corporeidad" de la institución política. (...) Pero, de otro lado, si la constitución del "gobierno" es necesaria para que el Estado exista y funciones como poder político, también debe ser útil y favorable a los individuos. (...) Esta es la segunda dimensión liberal de la constitución, desde entonces concebida como una ley fundamental. Igual que con los Padres fundadores de la revolución americana, se la concibe como el medio jurídico de proteger la soberanía del pueblo contra los gobernantes. (...) La constitución deja de ser únicamente una organización (una estructura), natural o artificial, pues es también una limitación» (Beaud, 2009, pp. 26-27). 
en contextos y textos que no conectan con su concepción moderna sino a reflexiones que estaban conduciendo a concluir que la constitución como seguridad de los derechos y sistema de separación y equilibrio de poderes se hacía necesaria», de manera que «surgieron algunos textos que en las tres últimas décadas del siglo XVIII y primeros años del XIX, estaban apuntando con claridad hacia una idea de constitución que contenía buenas dosis de constitucionalismo moderno» (Portillo, 2010, p. 130). Entre estos textos cabe destacar en España las propuestas en el sentido de establecer una monarquía constitucional de Victorián de Villava (?-1802), León de Arroyal y Alcázar (1755-1813), Gaspar Melchor de Jovellanos (1744-1811) y Valentín Tadeo de Foronda (1751-1821) ${ }^{123}$. Ahora bien, «conviene recordar que algunas de estas propuestas surgen en ambientes americanos de la monarquía y que lo hicieron en varia forma. (...) América fue escenario también donde la necesidad de la constitución se atisbó en el intento de generar nuevo orden al margen de la monarquía» (Portillo, 2010, pp. 131-132). Aunque antes de 1808 estaba lejos de ser una opción plenamente acogida por las elites criollas, hay algunos textos que indican que el uso del término constitución no era extraño en el contexto de aquellos años. Uno de los más conocidos ejemplos es Carta dirigida a los españoles americanos que entre 1791 y 1792 redactó Juan Pablo Vizcardo y Guzmán (1748-1798) ${ }^{124}$, aunque también es preciso resaltar la traducción que en 1793 hizo Antonio Nariño (1765-1823) de la Declaración francesa de 1789 bajo el título Derechos del hombre, que incluía la definición de constitución del artículo 16 a la que ya se ha hecho referencia ${ }^{125}$.

En conclusión, la formalización del derecho constitucional en documentos escritos es el punto culminante de un proceso que desde el siglo XVII y en particular desde las últimas décadas del siglo XVIII dotó a la palabra «constitución» de significados diferentes a los que tradicionalmente tenía, que la trasladaron al ámbito político-jurídico con un alcance más preciso, al punto que con esos contenidos tradicionales el significado moderno sólo tiene en común el nombre (Dippel, 2009, p. 13). De acuerdo con N. Luhmann, «ahora pensamos en la constitución como un texto jurídico que al mismo tiempo fija la constitución política de un Estado. La terminología jurídica

123 Las propuestas constitucionales de estos y otros autores son recogidas en la compilación de I. Fernández Sarasola (Fernández, 2004).

124 Véase la edición de D. Brading (Vizcardo y Guzmán, 2004).

125 El texto de la traducción de Nariño puede consultarse en la compilación de B. Marquardt (2009, pp. 13-15). 
y la terminología política se reúnen en el momento en que se produce una nueva fijación jurídica de un orden político y en el que percibimos el orden político como un orden jurídico» (Luhmann, 1990, p. 210). En síntesis, este proceso no sólo pone de presente que «el gobierno constitucional ya se había establecido antes de que el término "constitución" hubiere sido empleado»" (Maddox, 1989, p. 50), sino que, además, el uso del mismo supuso expulsar «progresivamente sus componentes no jurídicos para limitarse a los aspectos jurídicos de aquel $\mathrm{y},(\ldots)$ tras la transición al constitucionalismo moderno, limitarse a la ley reguladora de la organización y el ejercicio de la soberanía estatal, evolucionando así desde un concepto descriptivo a uno prescriptivo» (Grimm, 2006c, p. 107).

\section{2.}

\section{EL CONCEPTO DE CONSTITUCIÓN}

Si pasamos del uso del término a sus múltiples significados, es posible constatar que el debate teórico-doctrinal sobre el concepto de constitución refleja esa evolución del lenguaje ${ }^{126}$. En un conocido análisis sobre la

126 Antes de proceder a presentar algunas de las concepciones sobre la constitución conviene retomar la advertencia metodológica que hace J. Aguiló, al señalar que hay que evitar confundir las propiedades o características de una constitución con sus concepciones o teorías, aunque sea evidente que existe un vínculo entre los dos ámbitos. Así, «una cosa es afirmar que una determinada Constitución es democrática, y otra muy diferente es defender una lectura democrática de una determinada Constitución. La diferencia radica en que mientras en el primer caso se está diciendo que la democracia es una de las propiedades o características de la Constitución en cuestión, en el segundo se afirma que esa propiedad, la de ser una Constitución democrática, debe prevalecer frente a otras posibles propiedades de esa misma Constitución que pudieran entrar en conflicto con ella». La consecuencia más destacable de esta diferenciación es que las disputas entre las diversas concepciones de la constitución, de lo que nos ocuparemos en lo que sigue, «no versan sobre las propiedades que caracterizan una Constitución, sino sobre la preeminencia de unas sobre otras (...); la discusión relevante no versa sobre negaciones, versa sobre pesos y acentos» (Aguiló, Regla. 2004b, pp. 64-65). A ésta se une otra advertencia que plantea $\mathrm{K}$. Hesse cuando afirma que una cosa es definir la constitución en el marco de la teoría constitucional y otra es definirla en el marco de la teoría del derecho constitucional. En el primer caso, se trata de «preguntarse por un concepto abstracto de Constitución que dé cabida a lo que es común a todas o, al menos, a un bueno número de Constituciones históricas dejando de lado las peculiaridades de tiempo y lugar», mientras que «para la teoría del Derecho Constitucional un concepto así resultaría vacío de contenido y, por lo mismo, incapaz de fundamentar una compresión susceptible de encauzar la resolución de los problemas constitucionales prácticos planteados aquí y ahora» (Hesse, 1992, p. 3). Como es evidente, tomar una u 
cuestión, Carl Schmitt plantea un punto de partida ineludible: en la medida en que "todo lo imaginable puede tener una "constitución"», es preciso «limitar la palabra "constitución" a Constitución del Estado, es decir, de la unidad política de un pueblo» (Schmitt, 2001, p. 29). Esto significa que nos encontramos en el ámbito jurídico-político de la vida humana, el de las relaciones de poder, su estructuración y ordenación, y que en este contexto diversas concepciones se han propuesto. Es así como el mencionado autor distingue dos conceptos «absolutos» ${ }^{127}$ de constitución: uno que la concibe como «la situación total de la unidad y ordenación políticas»o, en otras palabras, como «la concreta manera de ser resultante de cualquier unidad política existente» (Schmitt, 2001, pp. 29-30); el otro que define la constitución como «una regulación legal fundamental, es decir, un sistema de normas supremas y últimas» (Schmitt, 2001, p. 33). Esta distinción, que lleva implícito un significativo debate sobre la naturaleza del derecho ${ }^{128}$,

otra opción depende de los objetivos de investigación, razón por la cual mientras que Hesse defiende la segunda, pues entiende que «la tarea de exponer los rasgos básicos del Derecho Constitucional vigente es la relativa a la Constitución actual, individual y concreta» (Hesse, 1992, p. 4), en este trabajo nos inclinaremos a mostrar las principales concepciones que sobre la constitución han surgido en diversos momentos históricos. De todas formas, ambos tipos de definiciones están estrechamente vinculadas, en tanto que aquella que se realiza respecto de un determinado Derecho Constitucional supone haber abordado, así sea de manera preliminar e implícita, la cuestión desde el ámbito de la teoría constitucional.

127 Para Schmitt son «absolutos» estos conceptos porque «ofrecen un todo (verdadero o pensado)» mientras que el concepto «relativo» se limita a definir la constitución como una ley constitucional concreta según sus características formales, que son externas y accesorias (Schmitt, 2001, pp. 29, 37). Se hace evidente así que este autor se inclina a ofrecer una definición esencialista o real de constitución (véase infra $\mathrm{n}$. 78).

128 En efecto, como lo explica R. Hernández Marín, uno de los temas centrales de la filosofía jurídica es el de la naturaleza del derecho, que comprende, a su vez, varias cuestiones, entre ellas la de la naturaleza de las entidades que integran el derecho, que ha sido abordada por la llamada «ontología jurídica». Así, es posible preguntarse si las entidades jurídicas son entidades factuales, existentes en el espacio y en el tiempo y susceptibles de observación empírica, o si son, por el contrario, entidades ideales o conceptuales, en concreto, el sentido o significado de una oración, es decir, si las normas son proposiciones (Hernández Marín, 1989, pp. 26-28). Con base en esto, aquel autor distingue dos concepciones sobre las entidades jurídicas: la que considera que son regularidades de comportamiento y la que considera que son proposiciones (Hernández Marín, 1989, pp. 37-38). Ahora bien, la segunda concepción puede concretarse en el sentido de que son únicamente un tipo de proposiciones las que integran el derecho, las proposiciones prescriptivas. Esta es, por ejemplo, la postura de N. Bobbio, para quien «un código, una Constitución son un conjunto de proposiciones (...), las normas 
puede ser utilizada como criterio de clasificación de las variadas formas de entender la constitución ${ }^{129}$.

\subsection{CONCEPTO EMPÍRICO Y CONCEPTO NORMATIVO}

El primer concepto propuesto por Schmitt, que podemos llamar concepto empírico ofáctico de constitución, la concibe como la estructura de ejercicio de poder político que efectivamente existe en una sociedad. La constitución

jurídicas hacen parte de la categoría general de las proposiciones prescriptivas. (...) Por "proposición" entendemos un conjunto de palabras que tienen un significado entre sí», razón por la cual hay que distinguir la proposición de su enunciado, esto es, «la forma gramatical y lingüística con la cual se expresa un significado, por lo que la misma proposición puede tener diversos enunciados, y el mismo enunciado puede expresar diversas proposiciones» (Bobbio, 1994, pp. 41-42). Las proposiciones prescriptivas se caracterizan por tener la función de dirigir, determinar o influir en el comportamiento ajeno para modificarlo, lo que las distingue de las proposiciones descriptivas, cuya función es la de hacer conocer o informar sobre una realidad cualquiera. Las prescripciones, en particular un tipo de ellas, los mandatos u órdenes, están en el centro del lenguaje normativo (Bobbio, 1994, p. 45), y se caracterizan, entre otras cosas, porque respecto a ellas no se puede afirmar que sean verdaderas o falsas. «Verdad o falsedad no son predicables de las proposiciones prescriptivas, sino de las proposiciones descriptivas. Los criterios evaluativos que fundamentan nuestra aceptación o rechazo de una prescripción son otros. (...) Entonces diremos que mientras no tiene sentido preguntarse si un precepto [o prescripción] es verdadero o falso, sí lo tiene preguntarse si es justo o injusto (oportuno o inoportuno, conveniente o inconveniente) o válido o inválido» (Bobbio, 1994, p. 48). Bajo estas premisas es posible identificar dos grandes tendencias sobre la naturaleza de las entidades que constituyen el derecho: por un lado, el idealismo jurídico que sostiene que el derecho está integrado por entidades ideales o proposicionales, en concreto por normas entendidas como prescripciones; por otro lado, el empirismo o factualismo jurídico, que sostiene que el derecho es un fenómeno factual, en concreto un fenómeno social consistente en el comportamiento de algunos miembros de la sociedad (por ejemplo, los jueces) o de todos ellos (Hernández Marín, 1989, pp. 57-58). Otra forma en que se plantea esta diferenciación es la que existe entre «ser» y «deber-ser». Para el normativismo (la concepción más extendida del idealismo) y, en particular «para los juristas neo-kantianos, el derecho no hace parte del dominio del ser, sino del deber ser, ya sea porque formula imperativos o porque hace parte del dominio del "espíritu”. (...) Sin embargo, las escuelas jurídicas realistas (...) rechazan la idea de la pertenecía del derecho al dominio del deber-ser», porque «la ciencia no puede tener el deber-ser como objeto y, en consecuencia, la ciencia del derecho no puede ser más que una ciencia de los comportamientos humanos» (Hartney, 1988, p. 153).

129 Se han ocupado de esta distinción, entre otros: Aragón, 2007: 30-31; Bastid, 1985: 12-14; Comanducci, 2007: 43; García de Enterría, 1983: 41-43; Löewenstein, 1983: 149-150. 
es entonces una realidad tangible, «una forma de ser, y no de deber ser (...) [una] inmanencia de las situaciones y estructuras sociales del presente» (García-Pelayo, 2000, p. 46). Es, en concreto, la manera especial de la ordenación política y social, «la forma especial del dominio que afecta a cada Estado, (...) la forma de gobierno. En tal caso, la palabra "forma" designa igualmente algo existente, un Status, y no algo acomodado a preceptos jurídicos o a lo normativamente debido» (Schmitt, 2001, p. 31) ${ }^{130}$. Ya se trate de una monarquía, de una dictadura o de una democracia representativa, esto es, independientemente de la forma de gobierno y de los fundamentos de legitimación que pueda tener, para esta concepción toda sociedad tiene necesariamente una constitución. Poco importa que haya o no un documento con el título de constitución, porque con esta palabra no se designa las normas o prescripciones que establecen los órganos políticos y regulan el ejercicio del poder, sino la manera como este poder en efecto se ejerce. Si algún valor tiene la constitución escrita es únicamente como producto o reflejo de la constitución real, de las condiciones de la sociedad que definen sus contenidos y funcionamiento, y si no se presenta como una derivación de las mismas no tiene ninguna importancia ${ }^{131}$. Usualmente se ha considerado

130 P. Comanducci, dentro de esta concepción empírica, que él denomina «modelos de la Constitución como orden», hace una clasificación entre «modelo axiológico de la Constitución concebida como orden» $\mathrm{y}$ «modelo descriptivo de la Constitución concebida como orden». Según el primer modelo, la constitución es «un conjunto de fenómenos sociales (entendida esta expresión en su sentido más amplio) que, en su conjunto y dentro de la esfera jurídico-política, aparecen dotados de máximo valor intrínseco o se presentan como generadores de normas». Para el segundo modelo la constitución consiste también en un conjunto de fenómenos sociales, pero que «no posee valor intrínseco ni genera normas, y que, como tal, puede ser descrito con los instrumentos de las ciencias sociales (...). De modo más preciso, "Constitución" designa, en esta acepción, una situación estable para un tiempo determinado de las relaciones de poder, sociales y políticas; equivale a la estructura fundamental de la sociedad y/o del Estado» (Comanducci, 2007, pp. 43-44).

131 Como lo explica F. Tomás y Valiente, el concepto empírico o sociológico de constitución «contribuye a poner de relieve, por un lado, la insuficiencia del concepto formal de Constitución y, por el otro, la ingenuidad de cualquier legalismo que pretenda identificar el cambio de o en la Constitución formal, de la Constitución como ley, con el cambio en la realidad que cada constitución trata de conformar. Más en particular, el concepto marxista de la superioridad y causación de los presupuestos socioeconómicos sobre los políticos ha llevado en la práctica a unas Constituciones, las de las llamadas democracias populares, desviadas de la línea del constitucionalismo liberal-democrático». No obstante, «el fracaso histórico de este modo de entender la primacía de la economía, el Estado de partido único, la infravaloración de las libertades 
que la noción de politeia de Aristóteles es uno de los paradigmas de esta manera empírica de entender la constitución (Bastid, 1985, p. 42; Guzmán Brito, 2002, p. 271; LöewenStein, 1983, p. 150; McIlwain, 1991, p. 45; Schmitt, 2001, p. 30; Verdú, 1994, p. 16), que se extendió al pensamiento político medieval e incluso al de los albores de la modernidad.

En efecto, entre los conceptos de politeia que Aristóteles (384 a. C.322 a. C.) ofrece en La política, se destaca aquel que la define como «la organización de los [oficios de] poder en la polis, [que fija] cómo se distribuyen, cuál es el elemento [soberano] de la politeia, y cuál es el fin de cada comunidad». Que este autor no tenía una concepción normativa de la politeia se hace evidente cuando a continuación explica que «[las] leyes, por el contrario, con características diferentes a las de una politeia, son [las reglas] según las cuales los magistrados deben gobernar a los súbditos y vigilar a los trasgresores. Es, pues, manifiesto que se necesita conocer las [diferentes] variedades y el límite de cada politeia, aun cuando [sólo sea] para establecer leyes» (La política, VI (IV), 1-1289a; Aristóteles, 2000, p. 166). Otro ejemplo clásico de una concepción empírica de constitución es el que ofrece el jurista romano Marco Tulio Cicerón (106 a. C.- 43 a. C.) quien utiliza la palabra latina constitutĭo para designar «directa o indirectamente al régimen político mixto, vale decir, a aquella estructura política integrada por la monarquía, la aristocracia y la democracia, por la que Cicerón manifiesta su preferencia y con el modelo de la cual interpreta la realidad histórica de la res publica romana» (Guzmán Brito, 2002, p. 290). A este noción de constitución como régimen político se refiere Cicerón cuando afirma que «de las tres formas primeras de gobierno a mi modo de ver, la mejor, y con mucho, es la monarquía; pero mejor que ella sería la forma de gobierno que se presente equilibrada y templada con las tres óptimas formas de poder. (...) Esta constitución ante todo tiene una cierta igualdad de la que a duras penas pueden carecer durante mucho tiempo los pueblos libres, y en segundo lugar estabilidad, puesto que las tres primeras formas indicadas fácilmente degeneran en los vicios contrarios (...)» (Sobre la República, I, 45, 69; Cicerón, 1992, p. 46-47) ${ }^{132}$. De otra parte, uno de los autores más representativos del pensamiento político-jurídico medieval,

"formales" y el concepto vicario de la Constitución, no debería conducir a un cómodo e interesado olvido del pensamiento marxiano, prematuramente enterrado por muchos (...)» (Tomás y Valiente, 1996, pp. 47-48).

132 Sobre el uso de los términos politeia y constitutio por parte de los escritores políticos de la tradición griega y romana, véase: Maddox (1989, pp. 52-55). 
Tomás de Aquino (1225-1274), en la misma línea que Aristóteles, asegura que «la mejor constitución (optima ordinatio principum) de una ciudad o reino es aquella en la cual uno solo tiene la presidencia de todos y es el depositario del poder; pero de tal modo que otros participen de tal poder, y que todos sean los dueños de tal poder (...). Tal es la mejor política (optima politia), la que está presidida por uno pero con un régimen mixto (bene conmixta)» (Summa theologica, I-IIae, q. 105 a. 1.; Aquino, 2000, p. 76). Como sucede en varias traducciones, la expresión ordinatio principum al significar «ordenación del gobierno» u «ordenación de las magistraturas», puede traducirse como «constitución» (Guzmán Brito, 2002, p. 280). Por lo demás, durante la transición a la modernidad todavía se mantiene una concepción empírica de constitución. Ejemplo de ello es la manera como Jean Bodin, en su obra Les six livres de la république (1576), retoma la clasificación aristotélica de las formas de gobierno, aunque para poner en duda la posibilidad de un gobierno mixto, en estos términos: «afirmamos que sólo hay tres estados o tres clases de república, que son: la monarquía, la aristocracia y la democracia. (...) Mas la mezcla de las tres repúblicas en una, no produce una especie diferente. El poder real, aristocrático y popular combinados sólo dan lugar al estado popular (...). En realidad, es imposible, incompatible e inimaginable combinar monarquía, estado popular y aristocracia. Si la soberanía es indivisible, como hemos demostrado, ¿cómo se podría dividir entre un príncipe, los señores y el pueblo a un mismo tiempo?» (Les six livres de la république, lib. II, cap. 1; Bodin, 2006, pp. 87-89).

Sin embargo, además de designar la forma de gobierno efectivamente existente en una sociedad, la concepción empírica de constitución la definió como el acto fundacional o de establecimiento del gobierno, con lo cual es posible distinguir desde esta perspectiva un sentido estático de uno dinámico de constitución (Guzmán Brito, 2002, pp. 294-299). En un sentido dinámico se la concibe como el proceso inicial y original de establecimiento de la sociedad política y del gobierno, como el acto a través del cual se constituye una determinada forma política en una sociedad. Fue la doctrina contractualista del siglo XVII la que desarrolló esta concepción al apartarse de la concepción aristotélica de la sociedad política como una formación natural que siempre ha existido y al afirmar su carácter artificial o instituido. Por ejemplo, Thomas Hobbes (1588-1679), en su conocido Leviatán (1651), utiliza la palabra constitución en este sentido cuando asegura que «la naturaleza de la justicia consiste en la observancia de los pactos válidos: 
ahora bien, la validez de los pactos no comienza sino con la constitución de un poder civil (the constitution of a civil power) suficiente para compeler a los hombres a observarlos» (Hobbes, 1980: 119) ${ }^{133}$. Junto con este sentido dinámico comienza a surgir durante el siglo XVIII uno estático que define a la constitución no sólo como el acto original de establecimiento del gobierno sino principalmente como el resultado del mismo, es decir, la forma o estructura del gobierno que en efecto existe en una sociedad ${ }^{134}$. Ejemplo de esta concepción es el uso que de la palabra constitución hace Jean-Jacques Burlamaqui (1694-1748) en un libro publicado en 1751 con el título Principes du droit politique en el que se ocupa de examinar «cuál es la constitución esencial (constitution essentielle) de los Estados, es decir, cuál es la manera como se forman y cuál es la estructura de esos edificios maravillosos» ${ }^{135}$. Montesquieu, a quien ya nos referíamos, se expresa en el mismo sentido en De l'esprit des lois, donde aparece varias veces la palabra «constitución». Así, cuando se ocupa de Inglaterra se refiere a la «constitución fundamental (constitution fondamentale) del gobierno» de este país, en la que «el cuerpo legislativo está compuesto de dos partes, cada una de las cuales tendrá sujeta a la otra por su mutua facultad de impedir, y

133 John L. también le da este sentido al término «constitución» cuando lo utiliza en sus Dos Tratados sobre el Gobierno (1689). Por ejemplo, en el Segundo Tratado (cap. XIII, § 157) considera que «la constitución del poder legislativo (the Constitution of the Legislative)» es «el acto original y supremo de la sociedad, anterior a toda ley positiva dictada en dicha sociedad, y dependiente de la totalidad del pueblo» (Locke, 2000, p. 162). En este contexto doctrinal, el 28 y 29 de enero de 1689 la Cámara de los Comunes del Parlamento aprobó dos resoluciones, que ya mencionábamos antes, en una de las cuales se hace referencia a la constitution con dicho significado, al acusar al rey Jacobo II de haber «intentado subvertir la constitución del reino (the constitution of the Kingdom), al romper el contrato original entre el rey y el pueblo y al violar las leyes fundamentales $(\ldots) »$.

134 De acuerdo con A. Guzmán el paso del sentido dinámico al estático de constitución se debió al desarrollo de la potencialidad semántica del vocablo, dado que una vez adoptado para designar al acto constitutivo de la forma de gobierno, se lo continuará utilizando para designar también a la forma de gobierno constituida. Se produjo de esta forma el fenómeno lingüístico de la metonimia, consistente en aplicar al efecto el término que designa a la causa (Guzmán, 2002, p. 299). Por lo demás, conviene retomar esa diferenciación, pero para plantearla respecto de la constitución concebida como norma, de manera que con el término constitución se puede designar tanto a la norma constitucional como a la condición jurídicamente configurada por esta norma, es decir, la forma o estructura de gobierno producto de la eficacia de aquella (Grimm, 2006b, p. 49).

135 Principes du droit politique, $1^{\text {a }}$ parte, cap. 4, párr. 1 (Burlamaqui, 1983, t. I, p. 30). 
ambas estarán frenadas por el poder ejecutivo que lo estará a su vez por el legislativo» ${ }^{136}$. Es más, este autor considera que el clima, la geografía, los hábitos y otras características de las sociedades determinan el contenido de las normas jurídicas, incluidas las constitucionales, en la medida en que son los factores decisivos en la formación del carácter de las personas ${ }^{137}$.

Además del anterior, durante el mismo periodo, en especial después de las revoluciones liberales de finales del siglo XVIII, se produjo otro cambio en la manera de concebir la constitución, que implicó una transición desde un concepto del ser a uno del deber ser. «Desde entonces la constitución suele identificarse con el conjunto de normas que regulan de modo fundamental la organización y el ejercicio del poder estatal, así como las relaciones entre el Estado y la sociedad» (Grimm, 2006a, p. 28). En pocas palabras, la constitución pasa a concebirse como un conjunto de normas, entendidas como prescripciones, pero no cualquier conjunto de normas,

136 Del espíritu de la leyes, libro XI, cap. 6 (Montesquieu, 1984, t. I, pp. 149-150). Ahora bien, para E. Tillet, en la obra de Montesquieu, «de la "constitución del Estado (o del gobierno)", entendida como lo que es, como la constatación de un orden político naturalmente establecido, se opera una sutil transición, sin estar jamás rigurosamente fundamentada, hacía "la constitución" entendida como lo que debe ser, es decir, una justa distribución de los poderes ejecutivo, legislativo y judicial» (Tillet, 2001, p. 287). Esta transición puede explicarse, de una parte, por las diferentes nociones que Montesquieu atribuye a la palabra constitución en su obra cumbre (Tillet, 1998), aunque la concepción empírica parece ser la que predomina, y, por la otra, por el hecho de ser uno de los autores que más contribuyó al paso del constitucionalismo antiguo al constitucionalismo moderno (Sklar, 1987, p. 113).

137 «Si es verdad -afirma Montesquieu- que el carácter del alma y las pasiones del corazón son muy diferentes según los distintos climas, las leyes deberán ser relativas a la diferencia de dichas pasiones y dichos caracteres. (...) Las distintas necesidades en los diferentes climas han dado origen a los diferentes modos de vida, y éstos, a su vez, han dado origen a las diversas especies de leyes» (Del espíritu de la leyes, libro XIV, cap. 1 y cap. 10; Montesquieu, 1984, t. I, pp. 197 y 203). En lo que a la geografía concierne, en esta misma obra se afirma que «los países fértiles son llanuras donde no se puede disputar nada al más fuerte; todos se someten a él y, una vez sometidos, es imposible recobrar el espíritu de libertad (...). En los países montañosos se puede conservar lo que se tiene, pero es muy poco lo que hay que conservar. La libertad, es decir, el Gobierno de que se disfruta, es el único bien que merece defenderse. Así, pues, hay más libertad en los países montañosos y abruptos que en aquellos que parecen más favorecidos por la Naturaleza» (libro XVIII, cap. 2; Montesquieu, 1984, t. I, p. 236). Los hábitos y costumbres son también otro factor que determina a las leyes, porque «aunque estén separadas no dejan de guardar entre sí grandes relaciones», al punto que «cuando un pueblo tiene buenas costumbres, las leyes se simplifican» (libro XIX, cap. 21 y 22; Montesquieu, 1984, t. I, 263). 
sino únicamente aquel integrado por las normas «fundamentales» ${ }^{138}$. Entre los primeros planteamientos de este concepto normativo de constitución se destaca el de Henry St. John vizconde de Bolingbroke (1678-1751), quien en $A$ dissertation upon Parties (1733-34) la definió como «el compendio de leyes, instituciones y costumbres (assemblage of laws, institutions and customs), que se derivan de ciertos principios invariables de la razón, y que se dirigen a ciertos objetivos invariables del bien público, con los cuales se compone el sistema general según el cual la comunidad ha estado de acuerdo en ser gobernada» (Bolingbroke, 1997, p. 88). De esta misma época hay otra definición en sentido normativo que también ha trascendido: la que Emer de Vattel (1714-1767) propone en su tratado Le droit des gens ou principes de la loi naturelle (1758), según la cual «el reglamento fundamental (réglement fondamental) que determina la manera según la cual la Autoridad Pública debe ser ejercida, es lo que forma la Constitución del Estado» ${ }^{139}$.

138 Son diversos los sentidos desde los que es posible considerar que una norma es «fundamental»: desde una perspectiva institucional, son fundamentales las normas que regulan la organización del Estado y el ejercicio del poder estatal; desde una perspectiva dogmática, son fundamentales las normas que regulan las relaciones entre el Estado y los ciudadanos (por ejemplo las normas que establecen derechos y libertades); desde una perspectiva jurídica, son fundamentales las normas que regulan la producción de normas jurídicas generales (éste es el concepto de constitución de H. Kelsen, al que nos referiremos más adelante); desde una perspectiva axiológica, son fundamentales las normas que expresan valores, principios y fines que determinan todo el ordenamiento jurídico (Guastini, 2007, pp. 17-18).

139 Le droit des gens, párr. 27 (Vattel, 1978, p. 31). El carácter normativo del concepto de constitución de este autor se confirma cuando lo vincula con el de leyes fundamentales, al afirmar que «las leyes que son hechas vislumbrando directamente al bien público son las Leyes Políticas, y en esta clase, que conciernen el mismo cuerpo y la esencia de la Sociedad, la forma del Gobierno, la manera en que la autoridad pública debe ejercerse, en una palabra, aquellas cuyo concurso forma la Constitución del Estado, son las leyes fundamentales» (Le droit des gens, párr. 29; Vattel, 1978, p. 32). Lo que se destaca de la definición propuesta por este autor es que con la expresión «leyes fundamentales» Vattel no se refiere a los principios inderogables pero de concreto y preciso contenido que rigen la monarquía francesa, según la visión tradicional de las mismas (véase supra apartado 2.2), sino a aquellos que establecen y regulan la esencia y la forma de gobierno de cualquier sociedad en términos abstractos, de manera que dicha expresión y el término «constitución» se convierten en sinónimos (Guzmán Brito, 2002, p. 288). De esta manera, «dos caracteres nuevos distinguen esta constitución de otras acepciones: la asociación con las leyes fundamentales, de una parte, y la imputación a la nación, de otra parte», aunque esto no significa que «se haya alcanzado el concepto moderno y jurídico de la constitución como texto único, en la medida en que es aún la reunión de diversas leyes fundamentales» (Beaud, 2009, pp. 22-23). 
Aunque el concepto normativo de constitución ha prevalecido hasta hoy, «el antiguo concepto empírico en modo alguno ha quedado obsoleto y suele regresar (...) cuando la constitución jurídica no se impone en la realidad social o produce efectos distintos de los esperados» (Grimm, 2006a, p. 28). Ejemplo de este retorno de la concepción empírica son las propuestas de Joseph de Maistre (1753-1821), para quien la constitución es el conjunto de las circunstancias ambientales de la sociedad ${ }^{140}$, las de Georg W. F. Hegel (1770-1831), quien la concibe como el orden fundamental de la convivencia civil $^{141}$, las de Lorenz Von Stein (1815-1890), al definir la constitución como la voluntad unitaria del Estado ${ }^{142}$ o las de Carl Schmitt y su concepto de constitución como decisión de conjunto sobre el modo y forma de la unidad política ${ }^{143}$. Si bien todas estas propuestas tienen en común reaccionar contra la concepción normativa que impulsó el constitucionalismo liberal, la concepción empirista no es patrimonio exclusivo de autores que, como

140 «QQué es una Constitución? No otra cosa que la solución al siguiente problema: Dadas la población, las costumbres, la religión, la situación geográfica, las relaciones politicas, las riquezas, las buenas y las malas cualidades de determinada Nación, hállense las leyes que le convienen» (Maistre, 1955, p. 143).

141 En uno de sus primeros escritos políticos, La constitución de Alemanía (1799-1802), Hegel asegura que «se equivocaría gravemente quien quisiera aprender lo que suele acontecer en Alemania según aquellos conceptos de lo que debe suceder, a saber: según las leyes políticas. (...) [Los alemanes] permanecen fieles a sus conceptos, al Derecho y a las leyes; pero los acontecimientos no se cuidan de estar de acuerdo con estos y, por eso, los que adquirirían ventaja con ello, se esfuerzan en ajustar ambas cosas [sucesos y teoría] mediante las palabras y con la autoridad de los conceptos. Pero el concepto que incluye a los restantes es el concepto de que Alemania, en sí misma, constituye todavía un Estado (...). La organización de este cuerpo político, que se denomina la constitución del Estado alemán, se había formado en una vida completamente distinta a la que hubo luego y hay ahora; la justicia y la fuerza, la sabiduría y la bravura de tiempos pasados, el honor y la sangre, el bienestar y la miseria de generaciones, se han corrompido hace mucho, pero sus costumbres y condiciones ya extinguidas se expresan en las formas de este cuerpo» (Hegel, 2010, pp. 27-28)..

142 En el trabajo titulado Geschichte der sozialen Bewegung in Frankreich von 1789 bis auf unsere Tage (1850) este autor define la constitución como «la forma en la que la pluralidad de la voluntad del pueblo se configura en voluntad unitaria del Estado» (citado en García-Pelayo, 2000, p. 50).

143 Para este autor la constitución «es una decisión consciente que la unidad política, a través del titular del poder constituyente, adopta por sí misma y se da a sí misma. (...) la esencia de la Constitución no está contenida en una ley o en una norma. En el fondo de toda normación reside una decisión política del titular del poder constituyente, es decir, del Pueblo en la Democracia y del Monarca en la Monarquía auténtica» (Schmitt, 2001, pp. 46-47). 
los citados, comparten una ideología conservadora. También hay quienes la han defendido para exigir la transformación de las estructuras políticosociales. Así lo hizo, entre otros, Ferdinand Lassalle (1825-1864), una de las figuras centrales del socialismo alemán, al concebir la constitución como «la suma de factores reales y efectivos que rigen en la sociedad» (Lassalle, 1997 , p. 99 ${ }^{144}$. Por lo demás, ha habido algunos intentos de articular un concepto empírico con uno normativo de constitución. Entre ellos se destaca el de Hermann Heller (1891-1933), que se distancia tanto de la concepción empirista de Schmitt como de la normativista que, como veremos, defiende Hans Kelsen (Heller, 1942, pp. 271-272). Para aquel autor, la permanencia de una constitución, que es una de sus características centrales, «se asienta, de una parte, en una mera normalidad de hecho, conforme a la Constitución, de la conducta de los miembros, pero además en una normalidad normada de los mismos y en el mismo sentido». Por consiguiente, puede distinguirse, «en toda Constitución estatal, y como contenidos parciales de la Constitución

144 De otra parte, en la teoría constitucional contemporánea es posible encontrar algunas nociones de constitución que se acercan a una concepción empírica. Por ejemplo, el concepto de «constitución material» de C. Mortati, quien la entiende como la «fuente suprema del ordenamiento» y le atribuye la función de servir «como fuente de validez o del establecimiento positivo de la constitución formal. (...) El elemento positivo o vigencia es carácter esencial del derecho y (...) los elementos, que sirven para otorgar fundamento a la previsión de la realización efectiva de las normas, deben ser considerados partes constitutivas del orden jurídico y no simples presupuestos. Son las fuerzas política las que garantizan el cumplimiento de tales previsiones mediante la organización que imprimen a la sociedad en la que actúan» (Mortati, 2000, p. 137). Otro ejemplo son las consideraciones de M. Troper cuando asegura que «la constitución pertenece al ámbito del Sein y no al del Sollen. No es obligatoria pero, en la medida en que abarca a todos los poderes públicos en un conjunto de relaciones numerosas y complejas, limita la libertad que tiene cada uno de ellos para determinar por sí solo sus propias competencias. Esta limitación no es de orden jurídico. No se trata de obligación sino de imposición. De ello se deriva que el estudio de la constitución no puede ser propio de una ciencia normativa y que es teóricamente posible aplicarle los métodos habituales de las ciencias que tratan los fenómenos del Sein; concretamente, nada impide que se intente poner en evidencia la existencia de relaciones de causalidad entre la constitución y el comportamiento efectivo de los poderes públicos» (Troper, 2001a, p. 295). En este mismo sentido, para P. L. Verdú «la Constitución es política; adjetivación que la penetra por entero. La Constitución es incomprensible si, por pureza metódica o por exageración del método técnico-jurídico, (...) ignoramos la realidad social. Esta realidad social opera como contrapunto de la normatividad. Es decir, se compone de exigencias socioeconómicas, de puntos de vista sobre la libertad, la igualdad y el pluralismo político (...), se inspira en ideologías políticas y en concepciones del mundo y de la vida (...)» (Verdú, 1994, p. 25). 
política total, la Constitución no normada y la normada, y dentro de ésta, la normada extrajurídicamente y la que lo es jurídicamente» (Heller, 1942, p. 269) $)^{145}$.

CONCEPTO RACIONAL-NORMATIVO Y CONCEPTO HISTÓRICOTRADICIONAL

A partir de la concepción normativa de constitución se han planteado numerosas clasificaciones. Una de ellas tiene como criterio el fundamento y origen de las normas constitucionales. Así, es posible distinguir entre concepto racional-normativo y concepto histórico-tradicional de constitución. El primero no sólo la concibe como un complejo de reglas o de prescripciones, sino que además ve en la constitución un sistema normativo que tiene un fundamento racional que permite la estructuración y el control del poder político. La constitución, entonces, «no representa una suma o resultante de decisiones parciales tomadas según van surgiendo

145 Heller fundamenta esta concepción de la constitución en que «así como no pueden estimarse completamente separados lo dinámico y lo estático, tampoco pueden serlo la normalidad y la normatividad, el ser y el deber ser en el concepto de la Constitución. Una Constitución política sólo puede concebirse como un ser al que dan forma las normas» (Heller, 1942: 269). El componente normativo de la constitución presenta «la inmensa importancia de que no sólo eleva considerablemente la probabilidad de un obrar conforme a la constitución por parte de los miembros actuales o futuros, sino que es sólo ella quien, en muchos casos, la hace posible» (Heller, 1942, p. 270). Sin embargo, el componente fáctico, «aquella parte del mundo circundante con la cual o frente a la cual la Constitución normada jurídicamente debe formar un todo, es lo que, en primer término, determina su contenido y su individualidad» (Heller, 1942: 274). Esta tensión supondría que en el ámbito constitucional sucede lo mismo que K. Olivecrona pone de presente cuando afirma que «el Derecho no puede ser, por una parte, un hecho (...) con causas y efectos naturales, y por otro lado, algo extraño al vínculo de causa y efecto» (Olivecrona, 1959: 7). Para Heller, entonces, el elemento definitorio de la constitución sería su componente empírico, lo cual se constata cuando concluye que «en última instancia, siempre veremos confirmarse la tesis de que la Constitución real consiste en la relaciones reales de poder» (Heller, 1942, p. 278), y cuando considera la constitución «como formación de la situación política total (...) como la estructura de poder característica del Estado, que persiste a través de las vivencias y actos concretos de sentido» (Heller, 1942, p. 288). También se constata cuando este autor, después de identificar cuatro conceptos de constitución, dos sociológicos y dos jurídicos, ubica el suyo entre los primeros, dado que como «concepto científico-real de Constitución», «se obtiene al señalar, desde un determinado punto de vista histórico-político, a una estructura básica del Estado como fundamental, en la totalidad estatal, y al destacarla como estructura relativamente permanente de la unidad estatal» (Heller, 1942, p. 294). 
los acontecimientos (...), sino que parte de la creencia en la posibilidad de establecer de una vez para siempre y de manera general un esquema de organización en el que se encierre la vida toda del Estado (...). Esto representa, a su vez, la aplicación al campo jurídico-político del mundo de las formas intelectuales de la Ilustración» (García-Pelayo, 2000, p. 34). Por ende, el contenido de las normas constitucionales y su estructuración no depende del arbitrio o de los intereses peculiares del detentador del poder en un momento dado, sino de un proceso racional que busca fundamentar dicho contenido y formalizarlo en categorías abstractas que, al ponerse por escrito, pretenden regular la diversidad y complejidad de las realidades concretas.

Bajo estas premisas el racionalismo normativista impulsó la positivización de la constitución en documentos que buscaban ofrecer un discurso constitucional claro y preciso y que estuviera al alcance de cualquier persona, lo que se sumó a «la idea general de que una cosa fijada por escrito puede ser demostrada mejor, que su contenido es estable y protegido contra modificaciones» (Schmitt, 2001, p. 39) ${ }^{146}$. Además, esta racionalización del ejercicio del poder supone que sus titulares no pueden disponer de la constitución, con lo cual se plantea una distinción fundamental: uno es el poder de elaboración y promulgación de la constitución (el poder constituyente), y otros los poderes sometidos a las normas constitucionales que ejercen sus competencias de acuerdo con sus previsiones (los poderes

146 La formalización y racionalización de las normas jurídicas, entre ellas las constitucionales, se explica por la puesta en duda del modelo jurídico medieval, que se vio afectado por la crisis general de la sociedad feudal entre los siglos XIV y XV. Como lo explica M. Calvo García, los cambios en el ámbito jurídico «tienen que ver en buena medida con las transformaciones sociales y políticas de la época; pero también con la crítica humanista a la tradición medieval y el surgimiento de un nuevo paradigma epistemológico: el racionalismo. (...) La razón va a ser el hilo conductor de la progresiva secularización del pensamiento práctico moderno y la seguridad es la luz que guía y alumbra este proceso. (...) La racionalización del derecho y la ciencia jurídica encuentra, así, fundamentos político-ideológicos: la necesidad de un derecho universalmente válido que ponga fin a las guerras de religión; una legislación perfecta y clara que contribuya a asegurar un orden social seguro y haga posible predecir de antemano las soluciones jurídicas eliminando los riesgos de la fortuna y la imprevisión; etc. (...) Con el lento y disperso advenimiento de la modernidad, tanto el derecho natural racionalista como la ley positiva se conciben como algo creado. (...) Ahora la ciencia va a producir el derecho, un derecho racional y universal que viene determinado por las excelencias del nuevo método racionalista que unifica el quehacer de un heterogéneo conjunto de juristas filósofos y filósofos juristas promoviendo las bases de una nueva disciplina: el "derecho natural racionalista"» (Calvo García, 1994, pp. 32-33). 
constituidos). Esto conduce a una concepción voluntarista de la constitución, que no sólo pretende tener un fundamento racional sino también legitimarse en el consentimiento de los miembros de la sociedad, directamente o por medio de sus representantes ${ }^{147}$. En palabras de Thomas Paine (1737-1809), autor de The Rights of Man (1781) y uno de los activistas más influyentes en el proceso de independencia de los Estados Unidos, «la Constitución de un país no es el acto de su gobierno, sino del pueblo que constituye su gobierno» (Paine, 1984, p. 192).

En contraposición con la anterior, para la concepción histórico-tradicional «la constitución de un pueblo no es un sistema producto de la razón, sino una estructura resultado de una lenta transformación histórica, en la que intervienen frecuentes motivos irracionales y fortuitos irreductibles a un esquema» (García-Pelayo, 2000, p. 42). En este caso la constitución también se concibe como un orden normativo fundamental, pero que no es producto de un acto de voluntad racional y consciente sino de las prácticas políticas que durante mucho tiempo se han ido desarrollando en una sociedad y que han demostrado su conveniencia precisamente porque se han implementado desde épocas remotas. El derecho constitucional está incrustado en la comunidad y en su pasado, y su antigüedad es la prueba de su justicia. Se confía más en la experiencia que en la razón en la configuración de los principios básicos de la organización política, motivo por el cual este concepto ha encontrado puntos en común con el concepto empírico de constitución, aunque evidentemente no la conciben de la misma forma: una cosa es afirmar que la constitución es un orden normativo que surge y se fundamenta en la práctica política y otra que la constitución es la misma práctica política.

El concepto histórico-tradicional de constitución tuvo un inusitado auge a finales del siglo XVIII, en particular en la Gran Bretaña, como respuesta al concepto revolucionario de constitución de la Revolución francesa, que tenía un evidente carácter racional-normativo. Por ejemplo, «en 1792 Arthur Young menciona con desprecio la noción francesa de constitución que dice, "es un nuevo término que han adoptado y que utilizan como si una

147 Conviene diferenciar aquí esta concepción voluntarista de la constitución de la que desarrolla Schmitt que, como acabamos de ver, la concibe como la «decisión consciente» de la unidad política. Mientras que para la primera la constitución es una norma que tiene su origen en un acto de voluntad de una autoridad humana, para la segunda la constitución es el propio acto de voluntad, como realidad fáctica, y no la norma que surge de este acto y que existe como prescripción. 
constitución fuese un pudding que se hace según receta"» (McIlwain, 1991, p. 15). Ahora bien, tal vez quien mejor expuso esta concepción histórica fue Edmund Burke (1729-1797), quien en sus Reflections on the Revolution in France de 1790 aseguró que «siguiendo el método natural en la dirección del Estado, no innovamos nunca totalmente en aquello que mejoramos, ni estamos por completo anticuados en lo que conservamos. Al adherirnos a nuestros antepasados de esta manera y sobre estos principios, no nos guiamos por la superstición de los arcaizantes, sino por el espíritu de la analogía filosófica. Al elegir la herencia hemos dado a nuestro sistema constitucional la imagen de una relación de consanguinidad, ligando la Constitución de nuestro país con nuestros más caros lazos domésticos, adoptando nuestras leyes fundamentales en el seno de nuestros afectos familiares, manteniendo inseparables y cuidando con el calor de sus beneficios combinados y recíprocos, nuestro Estado (...)» (Burke, 1996, p. 69). Conviene indicar que este historicismo constitucional no es exclusivamente británico. Por ejemplo, como lo explica F. Tomás y Valiente, «el doctrinarismo español, con Jovellanos (1744-1811) como precedente y Cánovas del Castillo (18281897) como epígono de éste, invocó la existencia de una "Constitución de Castilla" o "Constitución histórica" de España, y "la esencia de la Constitución monárquica" como vínculos a respetar a la hora de elaborar una Constitución escrita. (...) La constitución legal o escrita ha de respetar la "Constitución interna" de la nación como cristalización vinculante de su historia, lo que en la práctica política significa que la voluntad constituyente del legislador actual se encuentra limitada por la fidelidad a la Constitución histórica» (Tomás \& Valiente, 1996, p. 47).

Para la concepción histórico-tradicional el papel de los documentos constitucionales no es el de instaurar ex nihilo las normas que regulan y ordenan el ejercicio del poder, sino únicamente el de confirmar y asegurar las antiguas tradiciones y costumbres que han demostrado desde tiempo atrás su eficacia en este ámbito. Por el contrario, para la concepción racionalnormativa, la constitución, en particular si está plasmada en un documento escrito, no es sólo expresión de un orden sino que es, ante todo, creadora de ese orden (García-Pelayo, 2000, p. 35), el mecanismo que permite su realización ${ }^{148}$. Como ya se indicó, desde esta perspectiva la existencia de

148 Son varios los autores del siglo XVIII que plantean una visión mecanicista de la constitución, entre los cuales están Montesquieu, Madison e incluso Rousseau. De acuerdo con M. Troper, para ellos la constitución «es concebida ante todo como un mecanismo y las calidades que se le exigen son ante todo las de una mecánica eficaz: debe realizar aquello para lo que ha sido construida. Esta concepción, muy 
la constitución se explica por un acto de voluntad racional y consciente del titular del poder constituyente, que para el constitucionalismo de finales del siglo XVIII es el pueblo (Estados Unidos) o la nación (Francia), sin que sea necesaria una continuidad con el pasado y rompiéndose incluso con él (Tomás \& Valiente, 1996, p. 48) ${ }^{149}$. Así pues, las normas constitucionales se han erigido tanto a la manera de derecho consuetudinario como a la manera de derecho legislado (Kelsen, 2003, pp. 232-233; Schmitt, 2001, p. 39) ${ }^{150}$.

Entre las consecuencias de la distinción entre concepto racional-normativo y concepto histórico tradicional de constitución hay una que conviene destacar por sus implicaciones para la comprensión del fenómeno de la

extendida en este siglo cuyo héroe es Newton, se caracteriza por la profusión de metáforas mecánicas, balanzas, resortes, esferas, engranajes y demás contrapesos» (Troper, 2001b, p. 190). Ahora bien, esto no significa necesariamente que estos autores excluyeran la concepción normativa de la constitución, como lo supone Troper, sino más bien que pretenden complementarla con la concepción mecanicista. Por ende, el constitucionalismo moderno no sólo busca prescribir a los detentadores del poder respetar la constitución y las libertades, determinando el contenido de la ley y de las demás normas jurídicas, sino además establecer un sistema que por su misma estructura produzca necesariamente este resultado, estructura que tendrá sus más conocidos desarrollos en la doctrina de la separación de poderes de Montesquieu y en el modelo de checks and balances del constitucionalismo estadounidense.

149 La concepción racional-normativa de la constitución, en su articulación con la voluntarista, implica entonces que «la autoridad y el derecho están en las manos de los hombres, cuando asumen el empeño de la actividad constituyente, y se atribuyen el poder de determinar el curso de la historia constitucional. (...) La constitución es sustraída a la fuerza de la historia que lleva a las cosas a lo largo de sus imprevisibles caminos y es adscrita en exclusiva a la fuerza preventivamente determinada de la intencional voluntad humana» (Zagrebelsky, 1995a: 50-51).

150 Esta distinción se ha planteado de diversas maneras, en particular en lo que concierne a la constitución como orden normativo basado en la práctica política. Así, esta práctica puede extenderse en el tiempo, con lo cual se destaca su carácter histórico-tradicional, o puede referirse a realidades que no tienen un origen tan remoto y se relacionan con la forma como en el presente se ejerce la autoridad. En este sentido, M. J. Perry explica que la constitución no solo consiste en las normas contenidas en un documento, sino también en las «premisas» que, con independencia de que hayan sido o no establecidas en el texto constitucional, se han convertido en características fijas, ampliamente afirmadas y substanciales de la vida política de una comunidad (Perry, 1998, p. 107). Para designar a las normas constitucionales que existen a través de la práctica política se ha recurrido a la expresión «convenciones constitucionales». De hecho, corresponde a A. V. Dicey (1915, p. XLVIII-LVIII) el haberla propuesto para referirse a las normas que surgen de la actuación de los órganos superiores del Estado que al extenderse por un amplio periodo se erigen como precedentes a los cuales se les reconoce carácter obligatorio (Perales, 1986). 
recepción de los modelos constitucionales en Latinoamérica: la concepción de las normas constitucionales como el producto de la inteligencia humana en su búsqueda por racionalizar, controlar y planificar el ejercicio del poder justifica que en cualquier sociedad que persiga estos propósitos se pueda adaptar dichas normas con independencia de sus circunstancias particulares. Habría entonces un modelo constitucional universal que tiene la capacidad de influir en cualquier contexto. El constitucionalismo liberal alcanzó este grado de racionalismo y universalismo después de la Revolución francesa y durante el siglo XIX, lo cual facilitó su difusión por diversas partes del mundo (Rodríguez Villabona, 2011, pp. 3-4). Por ejemplo, para Benjamin Constant (1767-1830) «la felicidad de las sociedades y la seguridad de los individuos reposan sobre ciertos principios. Estos principios son verdaderos en todos los climas y bajo todas las latitudes. No pueden variar jamás, cualquiera que sean la extensión de un país, sus costumbres, sus creencias y sus usos. Es indiscutible, tanto en una aldea de veinte cabañas como en una nación de treinta millones de personas, que nadie puede ser arbitrariamente castigado sin haber sido juzgado en virtud de leyes admitidas y según formas prescritas, ni tampoco impedido de ejercer sus facultades físicas, morales, intelectuales e industriales, de una manera inocente y tranquila. Una constitución es la garantía de estos principios. Por consiguiente, todo lo que se refiere a estos principios es constitucional y, por consiguiente también, nada que no se refiere a los mismos es constitucional» (Constant, 1872 , p. 267). Por el contrario, como lo explica M. García-Pelayo, para la concepción histórico-tradicional «en cuanto que cada pueblo es una individualidad, es claro que la ordenación constitucional ha de responder al espíritu o al carácter nacional, sin que sea posible su extensión a otros países o su recepción por ellos» (García-Pelayo, 2000, p. 42). Así, por ejemplo, de acuerdo con Montesquieu (1689-1755) «las leyes políticas y civiles de cada nación no deben ser más que los casos particulares a los que se aplica la razón humana. Por ello, dichas leyes deben ser adecuadas al pueblo para el que fueron dictadas, de tal manera que sólo por una gran casualidad las de una nación pueden convenir a otra» (Del espíritu de la leyes, libro I, cap. 3; Montesquieu, 1984, t. I, p. 35) ${ }^{151}$.

151 Sobre los procesos de trasplante, recepción, adaptación e influencia en el derecho, véase: Rodríguez Villabona (2009). 


\subsection{LOS MODELOS HISTÓRICOS DE CONSTITUCIÓN}

Si se toma la anterior distinción y se tiene en cuenta también el concepto empírico de constitución, es posible introducir una clasificación de carácter diacrónico que diferencie tres modelos históricos de constitución: la constitución de los antiguos, que se concibe como orden o estructura ${ }^{152}$, la constitución medieval de carácter consuetudinario y la constitución moderna, en la que se privilegia su condición normativa y racional (Beaud, 2003 , p. 134). Mientras que en los dos primeros la organización efectiva del poder es el elemento definitorio del concepto de constitución, ya sea directamente o mediante la costumbre, en el segundo lo es su configuración como derecho positivo que establece un orden y unos límites a la autoridad. Ésta es otra forma de aproximarse a la diferenciación entre concepto empírico y concepto normativo de constitución: por un lado, «el viejo concepto de constitución era un concepto del ámbito del ser»; por el otro, «la constitución moderna fijaba en un documento con forma jurídica, con pretensión sistemática y exhaustiva, la exigencia de cómo debía organizarse y ejercerse el poder estatal; de este modo, la constitución se hizo una con la ley que regulaba la organización y el ejercicio del poder del Estado» (Grimm, 2006b, p. 49) ${ }^{153}$. En este orden de ideas, el paso del concepto medieval al moderno de constitución supuso que se alterara el modo de entender la validez jurídica: el derecho deja de ser válido en virtud de su antigüedad y su validez depende ahora de una decisión del órgano competente para promulgar normas, siguiendo el procedimiento previsto en el propio ordenamiento (Otto, 1999, p. 21).

152 Como lo explica M. Fioravanti, la concepción de la constitución de los antiguos (básicamente la de la doctrina de los clásicos griegos, esto es, Platón y Aristóteles, y en Roma la de Polibio y Cicerón) se concreta en una forma de gobierno que «no presupone ninguna "soberanía", y menos aún un "Estado", se refiere simplemente a un sistema de organización y de control de los diversos componentes de la sociedad históricamente dada, construido para dar eficacia a las acciones colectivas y para consentir, así, un pacífico reconocimiento de la común pertenencia política» (Fioravanti, 2001, p. 17).

153 Para A. Guzmán Brito, antes de esta trasformación hubo una «desconsideración normativa de la constitución», en la medida en que «hasta el siglo XVIII, la constitución no fue considerada un departamento propio de la ciencia jurídica. Los juristas romanos no se ocuparon de ella; y en la Baja Edad Media, y de ahí en adelante, se la entendió como parte de la política y, por ende, perteneciente a la filosofía práctica, que se estudiaba en la facultad de artes, no en la de leyes» (Guzmán Brito, 2002, p. 269). 
2.4. CONSTITUCIÓN EN SENTIDO FORMAL Y CONSTITUCIÓN EN SENTIDO MATERIAL

La distinción entre constitución en sentido formal y constitución en sentido material es más conocida que las anteriores. Entre los numerosos autores que la han planteado cabe destacar a Hans Kelsen (1881-1973), quien en su Teoría pura del derecho (2 $2^{\mathrm{a}}$ ed., 1960) define la constitución como «la norma o normas positivas que regulan la producción de normas jurídicas

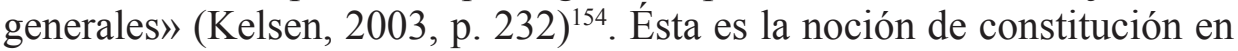
sentido material, mientras que por constitución en sentido formal se entiende «el documento denominado "constitución" que, como constitución escrita, no sólo contiene normas que regulan la legislación, esto es, la producción de normas jurídicas generales, sino también normas que se refieren a otros objetos políticamente importantes, así como disposiciones según las cuales las normas contenidas en ese documento, la ley constitucional, no pueden ser derogadas o modificadas como simples leyes, sino sólo bajo condiciones más difíciles mediante un procedimiento especial» (Kelsen, 2003, p. 233). Esto significa que en sentido formal la constitución es un orden de normas puesto por escrito en un documento que recibe este título y cuya aprobación y reforma están sometidas a mayores requisitos y condiciones que las de las leyes ordinarias ${ }^{155}$. Con constitución en sentido material, por su parte, «se

154 Esta noción de constitución hace que Kelsen vea en ella un conjunto de normas que fundamentan el Estado y el ordenamiento jurídico. Así, en otro de sus trabajos escribe que «la Constitución es siempre el fundamento del Estado, la base del ordenamiento jurídico de que se trate. Lo que se entiende ante todo y siempre por Constitución (...) es un principio en el que se expresa jurídicamente el equilibrio de las fuerzas políticas en el momento que se toma en consideración, es la norma que regula la elaboración de las leyes, de las normas generales en ejecución de las cuales se ejerce la actividad de los órganos estatales (...). Esta regla sobre la creación de las normas esenciales del Estado, sobre la determinación de los órganos y el procedimiento de la legislación forma la Constitución en el sentido propio, originario y estricto de la palabra. Es la base indispensable de las normas jurídicas que regulan la conducta recíproca de los miembros de la comunidad estatal, así como de aquéllas que determinan los órganos necesarios para aplicarlas e imponerlas y la forma en que estos órganos deben proceder, es decir, en suma, la base fundamental del ordenamiento estatal» (Kelsen, 1988, pp. 114-115).

155 De acuerdo con J. Aguiló un sistema jurídico-político cuenta con una constitución en sentido formal si se dan estas condiciones: 1) el conjunto de normas fundamentales de ese sistema se halla codificado en un documento escrito; 2) el procedimiento para la reforma o derogación de estas normas es más exigente que el de la legislación ordinaria; 3) la constitución ocupa una jerarquía normativa superior a la ley dentro del sistema de fuentes. En consecuencia, «la Constitución formal tiene al menos un 
alude al conjunto de normas cuyo objeto es la organización del Estado, los poderes de sus órganos, las relaciones de éstos entre sí y sus relaciones con los ciudadanos» (Otto, 1999, p. 17), con independencia de que se encuentren o no en la constitución escrita ${ }^{156}$. Mientras que la primera es una definición que apunta a la estructura de las normas constitucionales y al procedimiento de su elaboración y reforma ${ }^{157}$, la segunda tiene como referente el contenido de las mismas (Favoreu, 1999, pp. 92 y 96).

contenido mínimo que incluye el principio dinámico del sistema jurídico-político, de forma que la Constitución crea las formas básicas de la acción política y jurídica (órganos y procedimientos), pues como es sabido, la acción política en el marco del Estado no es acción natural o amorfa, sino acción institucional» (Aguiló, 2004a, pp. 35-36).

156 K. C. Wheare también plantea la distinción entre constitución en sentido formal y constitución en sentido material, aunque sin usar esta terminología, cuando explica que «la palabra Constitución se emplea por lo menos en dos sentidos en cualquier discusión sobre materia política. Designa en primer lugar todo sistema de gobierno de un país, el conjunto de normas que establecen y regulan o gobiernan el Estado. Estas normas en parte son legales, en el sentido de que los tribunales las reconocen y aplican, y en parte son extralegales, adoptando la forma de usos, acuerdos, costumbres o convenciones que los tribunales no reconocen como ley pero que no son menos efectivas en la regulación del gobierno que las normas legales en sentido estricto. (...) Pero en casi todos los países excepto Gran Bretaña la palabra Constitución se emplea en un sentido más restringido. Se utiliza para designar no el conjunto de normas legales y extralegales, sino más bien una selección de ellas que comúnmente se recopilan en un documento o documentos estrechamente relacionados entre sí. (...) La Constitución, pues, para la mayor parte de países, es una selección de normas legales que regulan el gobierno del país y que han sido articuladas en un documento» (Wheare, 1975, pp. 7-8).

157 Conviene mencionar aquí la distinción que en un texto de 1906 hizo G. Jellinek entre reforma y mutación de la constitución: «Por reforma de la Constitución entiendo la modificación de los textos constitucionales producida por acciones voluntarias e intencionadas. Y por mutación de la Constitución, entiendo la modificación que deja indemne su texto sin cambiarlo formalmente, que se produce por hechos que no tienen que ir acompañados por la intención, o conciencia, de tal mutación» (Jellinek, 1991, p. 7). Lo interesante es que este autor reconoce, frente a la mutación, que «los límites de la Constitución, como los de la ley, son siempre inciertos y no hay ninguna garantía de que las leyes que pretenden basarse en la Constitución no la contravengan a pesar de todo, produciendo así un cambio de la Constitución que no lo querían o, por lo menos, no lo pretendían explícitamente. Los preceptos constitucionales a menudo son oscuros o extensos y sólo el legislador les da un sentido preciso mediante leyes que los concretan de modo muy parejo a como el juez, primero, toma conciencia clara del contenido de las leyes que ha de aplicar. Así como por lo general la aplicación jurisprudencial de los textos legales vigentes está sujeta a las necesidades y opiniones variables de los hombres, lo mismo ocurre con el legislador, cuando interpreta mediante leyes ordinarias la Constitución. Lo que parece en un tiempo inconstitucional emerge más tarde conforme a la Constitución y así la Constitución sufre, mediante el cambio 


\subsection{CONSTITUCIONES RÍGIDAS Y FLEXIBLES}

En la mención de Kelsen a los procedimientos de reforma se evidencia otra clasificación: la que distingue las constituciones rígidas, esto es, aquellas cuya reforma o revisión está sometida a condiciones especiales y más difíciles de realizar, de las constituciones flexibles, en las que no se prevén este tipo de condiciones y cuya reforma se realiza mediante el mismo procedimiento de las leyes ordinarias158. Incluso es posible

de su interpretación, una mutación. No sólo el legislador puede provocar semejantes mutaciones, también pueden producirse de modo efectivo mediante la práctica parlamentaria, la administrativa o gubernamental y la de los tribunales» (Jellinek, 1991, pp. 15-16). Por otra parte, en lo que concierne a la reforma de la constitución, A. Ross se ha ocupado de la paradoja de la auto-referencia o reflexividad que afecta a la cláusula o artículo constitucional que establece el procedimiento de reforma de la propia constitución. Esta situación se debe a que este artículo se refiere a la reforma de la constitución y, por ende, a sí mismo, y las oraciones auto-referentes o reflexivas carecen de significado (piénsese, por ejemplo, en el enunciado «esta proposición es falsa», referido a sí mismo) (Ross, 2001, p. 59). Para una revisión de los problemas que plantea la reforma de la constitución, véase: Ardant (1993); Hesse (1992, pp. 23 25; 2001, pp. 9-20); Löewenstein (1983, pp. 162-199); Pegoraro (2008); Pérez Royo (1986); Ruipérez (1997); Vega García (1991).

158 Esta distinción se debe al historiador y político inglés James Bryce, quien en un texto titulado Constituciones flexibles y constituciones rígidas de 1901 advierte que el criterio de esta clasificación es «la relación de cada Constitución con las leyes ordinarias y con la autoridad ordinaria que las dicta» (Bryce, 1962, p. 19). Con base en este criterio es posible identificar algunas constituciones que «están a igual nivel que las otras leyes del país (...). Tales constituciones proceden de las mismas autoridades que hacen las leyes ordinarias y son promulgadas y abolidas según el mismo procedimiento que aquellas» Por otra parte, «otras constituciones, la mayoría de ellas pertenecientes al tipo más moderno o estatutarias, están por encima de las otras leyes del país que regulan. El instrumento -o instrumentos- en el que están contenidas estas constituciones no procede de la misma fuente que las otras leyes, es promulgado por procedimiento distinto y posee mayor fuerza. Su proclamación no corresponde a la autoridad legislativa ordinaria, sino a alguna persona o corporación superior o con poder especial. Si es susceptible de cambio, éste se llevará a efecto únicamente por dicha autoridad, persona o corporación especial» (Bryce, 1962, p. 19-21). En este orden de ideas, las constituciones del primer tipo «pueden llamarse flexibles, porque poseen elasticidad y se adaptan y alteran sus formas, sin perder sus características principales. Las constituciones del tipo más moderno no poseen esta propiedad, porque su estructura es dura y fija. Por lo tanto, no hay inconveniente en darles el nombre de constituciones rígidas» (Bryce, 1962, p. 26). Por su parte, G. Jellinek considera que la rigidez es la característica definitoria de una constitución, dado que «la nota jurídica esencial de las leyes constitucionales radica exclusivamente en la superioridad de su fuerza como leyes, desde el punto de vista formal. En aquellos Estados en que las 
concebir, como lo propone Schmitt, una «constitución absolutamente rígida» que «necesitaría prohibir todo cambio de cualquiera de sus prescripciones» (Schmitt, 2001: 42). Aunque en la actualidad no existe ninguna constitución íntegramente irreformable, hay varias que disponen que algunos de sus artículos, cláusulas o principios no puedan ser reformados mediante el procedimiento previsto en la propia constitución. Se trata de las denominadas cláusulas pétreas, intocables, irreformables, o eternas. Con todo, éstas no son restricciones formales sino «límites fijados al contenido o sustancia de una reforma constitucional, o sea, que operan como verdaderas limitaciones al ejercicio del poder constituyente reformador o "derivado"» (Vanossi, 2002, p. 253). Estos límites sustantivos o de contenido pueden ser expresos o tácitos. De acuerdo con Löewenstein es preciso distinguir entre las «medidas para proteger concretas instituciones constitucionales -intangibilidad articulada-, y (...) aquellas que sirven para garantizar determinados valores fundamentales de la Constitución que no deben estar necesariamente expresados en disposiciones o en instituciones concretas, sino que rigen como "implícitos", "inmanentes" o "inherentes" a la Constitución. En el primer caso determinadas normas constitucionales se sustraen a cualquier enmienda por medio de una prohibición jurídicoconstitucional, y en el segundo caso la prohibición de reforma se produce a partir del "espíritu" o "telos" de la Constitución, sin una proclamación expresa en una proposición jurídico-constitucional» (Löewenstein, 1983, p. 189). A partir de esta distinción es posible plantear otra, la que existe entre la aprobación de una nueva constitución y la reforma constitucional parcial. «El acto de dar la Constitución es cualitativamente distinto del de reformarla (es decir, revisar las leyes constitucionales contenidas en el texto), porque en un caso se entiende por constitución la decisión de totalidad, y en otro, la ley constitucional. Por eso una Asamblea "constituyente" es cualitativamente distinta de un Parlamento, de un Cuerpo legislativo normal, o sea, constitucionalmente previsto» (Schmitt, 2001, p. 50) ${ }^{159}$.

constituciones ni por su fijación ni por su modificación se distinguen de una manera especial, carecen éstas de toda significación práctica en la vida del derecho» (Jellinek, 2000, pp. 480-481).

159 Como se advierte en estas consideraciones de Schmitt, las implicaciones de la distinción entre instauración o sustitución, por un lado, y reforma, por el otro, dependen de la concepción de constitución que se plantee como punto de partida. Así, como lo explica R. Guastini, una concepción sustancial de la constitución, que la conciba como una totalidad coherente y conexa de valores ético-políticos, implica que «una cosa es revisar la Constitución existente (en sus normas de detalle) sin alterar la identidad material o 
2.6. EL CONCEPTO «MÍNIMO» DE CONSTITUCIÓN Y SU GARANTÍA: CONSTITUCIÓN COMO RÉGIMEN U ORGANIZACIÓN Y CONSTITUCIÓN COMO NORMA SUPREMA

La noción de constitución en sentido material puede precisarse todavía más. Frente a un concepto material de constitución en sentido amplio se propone así un concepto material de constitución en sentido estricto o un «concepto mínimo» de constitución (Tomás \& Valiente, 1996, p. 49), cuya más conocida manifestación es el artículo 16 de la declaración francesa

axiológica, y otra cuestión es modificar el "espíritu” de la Constitución existente, o sea, alterar, perturbar o subvertir los valores ético-políticos que la caracterizan», de manera que «en ningún caso puede la reforma constitucional ser llevada hasta modificar los principios supremos de la Constitución existente» (Guastini, 2007, pp. 24-25). Por su parte, una concepción formal, que conciba la constitución como un conjunto de normas que se identifica por la simple enumeración de los elementos que lo componen, supone que «toda reforma constitucional -por más "marginal" que sea desde un punto de vista axiológico-produce una nueva Constitución» y, por ende, «reforma constitucional e instauración son (...) cosas simplemente indistinguibles bajo un perfil sustancial», al tiempo que sólo se puede «distinguir reforma e instauración sobre la base de elementos puramente formales». En consecuencia, para esta concepción «toda modificación constitucional realizada en forma legal -por más que pueda incidir profundamente sobre la constitución existente- es mera reforma», mientras que «toda modificación realizada en forma ilegal - por más marginal que pueda ser ese cambio- es instauración de una nueva Constitución» (Guastini, 2007, pp. 25-26). Siguiendo la primera concepción, la Corte Constitucional colombiana distingue entre la reforma y la sustitución de la constitución, al señalar que «aunque la Constitución de 1991 no establece expresamente ninguna cláusula pétrea o inmodificable, esto no significa que el poder de reforma no tenga límites. El poder de reforma, por ser un poder constituido, tiene límites materiales, pues la facultad de reformar la Constitución no contiene la posibilidad de derogarla, subvertirla o sustituirla en su integridad. Para saber si el poder de reforma (...) incurrió en un vicio de competencia, el juez constitucional debe analizar si la Carta fue o no sustituida por otra, para lo cual es necesario tener en cuenta los principios y valores que la Constitución contiene, y aquellos que surgen del bloque de constitucionalidad, no para revisar el contenido mismo de la reforma comparando un artículo del texto reformatorio con una regla, norma o principio constitucional - lo cual equivaldría a ejercer un control material. Por ejemplo, no podría utilizarse el poder de reforma para sustituir el Estado social y democrático de derecho con forma republicana (C.P. art. $1^{\circ}$ ) por un Estado totalitario, por una dictadura o por una monarquía, pues ello implicaría que la Constitución de 1991 fue remplazada por otra diferente, aunque formalmente se haya recurrido al poder de reforma» (Sentencia C-551 de 2003, M.P. Eduardo Montealegre Lynett). Sobre el control constitucional de la reforma a la Constitución puede consultarse los siguientes trabajos: Guastini (2001); Ramírez Cleves (2005); Rodríguez Gaona (2006). 
de derechos de 1789, al que ya se hizo referencia. No basta entonces con que un conjunto de normas cumpla con algunas condiciones formales o que regule la organización de los órganos del Estado y el proceso de creación del derecho positivo para que pueda considerarse como una auténtica constitución. Es necesario además que tengan un determinado contenido que responda a ciertas exigencias políticas y éticas, que al final del siglo XVIII eran la limitación del poder político mediante la garantía de los derechos individuales -según la concepción del iusnaturalismo racionalista - y la separación o distribución de los poderes (Grimm, 2006b, p. 60; Matteucci, 2005, p. 346) ${ }^{160}$. Por consiguiente, contrario a lo que supone la concepción empírica, para esta concepción no todas las sociedades tienen necesariamente una constitución, sino únicamente aquellas que poseen una que corresponda a determinados criterios materiales ${ }^{161}$.

160 Para C. S. Nino esta tensión implica que hay dos sentidos de constitucionalismo: por una parte, un sentido «mínimo» que «se refiere al requerimiento de que un Estado tenga una constitución en el vértice de su sistema jurídico», entendida como «conjunto de normas que dispone la organización básica del poder político y la relación entre el Estado y los individuos»; por otra parte, un sentido «pleno» de constitucionalismo que «requiere no sólo la existencia de normas que organizan el poder y que están en cierto modo atrincheradas frente a proceso legislativo normal, sino también y preeminentemente que se satisfagan ciertas exigencias acerca del procedimiento y contenido de las leyes que regulan la vida pública» (Nino, 1992, p. 3-4). Por su parte, una distinción similar a la de concepto material en sentido amplio y concepto material en sentido estricto la propone P. Comanducci cuando distingue entre «modelo descriptivo de la Constitución concebida como norma» y «modelo axiológico de la Constitución concebida como norma» (uniendo estos dos modelos con los dos que se mencionaron antes [supra $\mathrm{n} .18$ ] este autor propone cuatro modelos básicos de constitución). Esos dos modelos coinciden en que conciben la constitución como «un conjunto de reglas jurídicas positivas, consuetudinarias o expresadas en un documento que, respecto a las otras reglas jurídicas, son fundamentales». Ahora bien, la diferencia está en que para el modelo axiológico ese conjunto de reglas posee o debe poseer «determinados contenidos a los que se les atribuye un valor específico», de manera que «la Constitución es un valor por sí misma» (Comanducci, 2007, p. 44). En otras palabras, «se pasa a un modelo axiológico cuando se considera al objeto Constitución en sí mismo como dotado de un valor positivo y como generador de normas» (Comanducci, 2007, p. 51). Por lo demás, mientras que el modelo descriptivo «adquirió plena autonomía cuando se asentó el positivismo jurídico», el axiológico «aparece vinculado genéticamente con la ideología constitucionalista» (Comanducci, 2007, p. 52).

161 Teniendo esto es cuenta, es posible diferenciar, como lo hace J. Aguiló, entre constitución necesaria y constitución contingente, «lo que supone oponer aquellos conceptos de Constitución que presuponen que todo sistema jurídico-político estable cuenta con una Constitución a aquellos otros conceptos que no lo presuponen» (Aguiló, 2004a, p. 25). Entre los primeros se encuentra, además del concepto empírico o fáctico 
Siguiendo esta línea, no son pocos los autores que han tratado de encontrar los contenidos sustantivos que definen la constitución ${ }^{162}$. Entre los intentos que se han hecho cabe destacar el de Karl Löewenstein quien define la constitución como «el dispositivo fundamental para el control del proceso del poder» (Löewenstein, 1983, p. 149), que se concreta en cinco elementos fundamentales, el «mínimo irreductible de una auténtica Constitución»: 1) la asignación de diversas funciones o competencias a diferentes órganos estatales, con lo cual se evita la concentración del poder en una sola instancia y se realiza el denominado principio de separación de poderes; 2) al lado de la separación y distribución, el establecimiento de mecanismos de cooperación y equilibrio entre las instituciones, como el de los frenos

de constitución, el concepto material de constitución en sentido amplio o concepto del positivismo normativista (ejemplificado por la definición de constitución que ofrece Kelsen, a la que ya hacíamos referencia), que considera que «todo sistema jurídicopolítico positivo (existente, estable) cuenta con un conjunto de normas a las que se remite su identificación, unidad y permanencia» (Aguiló, 2004a, p. 29-30; véase también Guastini, 2007, p. 18). Ejemplos de concepto contingente de constitución son el de constitución en sentido formal, en tanto que no todas las sociedades cuentan con un documento que contenga las normas fundamentales de su sistema jurídico-político, y el de constitución material en sentido estricto o «concepto mínimo» de constitución, que también niega que todas las sociedades tengan una constitución, pues sólo la tienen aquellas cuya constitución pretende «una determinada configuración del poder político y el aseguramiento del respeto de los derechos; y, en este sentido, la Constitución del constitucionalismo tiene que tener necesariamente un fuerte componente de liberación política, es decir, de erradicación de los males más característicos de las dominaciones políticas: (...) la arbitrariedad, el autoritarismo, la exclusión política y la exclusión social» (Aguiló, 2004a, pp. 38-39).

162 También conviene hacer referencia aquí a aquellos autores que consideran que los contenidos sustantivos, en concreto la limitación del poder político, no son centrales en la definición de constitución, planeando así un concepto material de constitución en sentido amplio. Un ejemplo destacable es el de K. C. Wheare quien en un conocido texto publicado en 1951 con el título Modern Constitutions, asegura que «no hace falta (...) negar el nombre de Constitución al documento que contiene un conjunto de normas importantes que regulan la gobernación de un país, aun cuando estas normas no pretendan limitar los poderes del cuerpo legislativo que, de hecho, ellas han establecido» (Wheare, 1975, p. 12). Es más, este autor llega a afirmar que dadas «las dificultades [que] surgen cuando en la vida práctica de un país modestamente se intenta poner en vigor los derechos otorgados en su Constitución» (Wheare, 1975, p. 48), «la Constitución ideal debería contener pocas o ninguna declaración de derechos (...). Estos no pueden proclamarse en una Constitución si no es en forma absoluta y genérica, salvo que de hecho sean de tal modo especificados que no tengan sentido (...). Es en la ley ordinaria donde la cuidadosa definición de los derechos puede enfocarse mejor» (Wheare, 1975, p. 53). 
y contrapesos (checks and balances); 3) el reconocimiento del electorado, conformado por todos los adultos mayores de edad, como el árbitro supremo en los conflictos entre los órganos del poder público, para evitar así que uno de ellos se imponga autocráticamente sobre los demás, lo cual es expresión del carácter demo-liberal del constitucionalismo contemporáneo; 4) la previsión de mecanismos de reforma o revisión de la constitución, con el propósito de adaptarla a las cambiantes condiciones sociales y políticas e impedir el recurso a medios extra-constitucionales, revolucionarios, ilegales o violentos para lograr este cometido; 5) la afirmación explícita de los derechos y libertades fundamentales de las personas y su protección frente a la acción de los detentadores del poder (Löewenstein, 1983, p. 153) ${ }^{163}$. A pesar de que el concepto material de constitución en sentido estricto se ha afianzado «después de la promulgación de las constituciones europeas de la posguerra y, sobre todo, en los últimos veinte años» (Comanducci, 2007, p. 52), el concepto en sentido amplio también puede responder, en ciertos contextos y al menos parcialmente, a la exigencia de limitar el poder político, «ya que el hecho de que haya reglas que definen de una u otra forma la organización del poder y la relación del Estado con los ciudadanos y que esas reglas no estén sujetas al proceso legislativo normal puede implicar ciertas garantías básicas de los ciudadanos en contra de abusos autoritarios»» (Nino, 1992, p. 3) ${ }^{164}$.

163 Para Löewenstein cuando no se cumple con estos contenidos mínimos estamos ante una «constitución semántica» que no pasa de ser «la formalización de la existente situación del poder político en beneficio exclusivo de los detentadores del poder fáctico, que disponen del aparato coactivo del Estado». Este caso es diferente del de una constitución que es jurídicamente válida pero que carece de realidad existencial, porque la dinámica del proceso político no se adapta a sus normas. Esta situación de ineficacia hace de ella una constitución «nominal» (Löewenstein, 1983, pp. 218-219). Por su parte, G. Sartori denomina al primer tipo «constitución nominal», en tanto que son textos que se limitan a llevar el nombre de «constitución» y a organizar el poder político sin limitarlo, mientras que al segundo tipo lo denomina «constituciones falsas», en tanto que en este caso las constituciones tienen la apariencia de una verdadera constitución pero no son efectivamente observadas (Sartori, 1962, p. 861).

164 Este mismo autor pone un interesante ejemplo de esta situación con el caso del régimen de Pinochet en Chile: «como se sabe este régimen trató de legitimarse a sí mismo en 1980 mediante una Constitución que fue votada en un plebiscito (...). Esta Constitución tenía muchas regulaciones grotescamente antidemocráticas. Sin embargo, es opinión generalizada en Chile que ella contribuyó a contener muchos abusos del gobierno militar y que muchos avances de las fuerzas democráticas fueron logrados invocando sus disposiciones ante tribunales que a veces estaban inclinados a salvar la cara ante la opinión pública nacional e internacional» (Nino, 1992, p. 3). Seguramente pueden 
Precisamente, frente a dichos contenidos mínimos la pregunta que surge es la de cómo garantizar su realización efectiva. Una posibilidad es instaurar en las normas constitucionales una organización de las entidades estatales en la que se definan sus fines, sus competencias, los procedimientos para el ejercicio de las mismas y las relaciones que mantienen entre ellas. Las constituciones de Europa continental, empezando por la francesa de 1791, siguieron esta opción estableciendo el denominado régimen representativo, concreción institucional del principio de separación de poderes. Ahora bien, como lo pone de presente Ignacio de Otto, «en Europa no llega a afianzarse claramente la idea de que esa Constitución escrita es efectivamente una norma jurídica que obliga a los poderes del Estado (...). La finalidad garantista del constitucionalismo se persigue por una vía interna -por así decirlo-al aparato de poder del Estado, de modo que Estado constitucional significa Estado organizado con arreglo a ciertos principios, pero no necesariamente sumisión de los poderes del Estado a normas situadas por encima de ellos» (Otto, 1999, p. 13). Precisamente, concebir la constitución como una norma obligatoria a la que se someten directamente las autoridades públicas es la otra manera de garantizar sus contenidos sustantivos. Esta opción surge en Estados Unidos desde el final del siglo XVIII, mientras que en Europa comienza a adaptarse en el periodo de entreguerras del siglo XX, para ser acogida con posterioridad en diversas partes del mundo. Por consiguiente, es posible distinguir entre constitución como régimen $u$ organización y constitución como norma suprema ${ }^{165}$. Aunque no se trata

encontrarse ejemplos similares a éste en Colombia durante los años ochentas bajo el régimen de «estado de sitio» previsto por la constitución de 1886.

165 En este caso el criterio de clasificación consiste en el modo de garantizar la eficacia de los contenidos constitucionales. M. Troper hace una propuesta semejante al distinguir el modelo mecanicista y el modelo normativo de constitución: mientras que en el primero «no se espera que los gobernantes se sometan libremente a reglas obligatorias, sino que la organización misma del sistema determine comportamientos a los que los gobernantes no puedan sustraerse», en el segundo «las autoridades se comportan en conformidad con las reglas constitucionales, entendidas como obligatorias» (Troper, 1999, p. 331). La constitución como «máquina» institucional garantiza su inviolabilidad no en virtud de la existencia de controles y de sanciones, sino porque «el reparto de competencias es tal que si una autoridad intentara violar la constitución, es decir, sobrepasar sus competencias, chocaría inmediatamente con otra autoridad, que tendría interés en oponerse a la primera. La garantía de la constitución no reside, pues, en un cuerpo de control. Es puramente interna» (Troper, 1999, pp. 334-335). La constitución como norma, por su parte, implica que tenga carácter obligatorio, lo que presupone que sus contenidos sean claros y precisos, lo cual permite conocer la naturaleza y 
de dos concepciones que necesariamente se contraponen ${ }^{166}$, las diferencias entre una y otra son de trascendencia, puesto que «sólo hay Constitución como norma cuando el ordenamiento establece que el cumplimiento de [sus] preceptos es obligatorio y, en consecuencia, que su infracción es antijurídica. (...) Por ello es posible decir que no tienen Constitución Estados que son constitucionales en el sentido de que su estructura y funcionamiento obedecen a las exigencias del constitucionalismo como movimiento político, pero en los cuales no se utiliza la técnica concreta de establecer una norma suprema con la que quepa enjuiciar tanto la legislación como cualquier otra función del Estado» (Otto, 1999, pp. 15 y 17) ${ }^{167}$.

el contenido de las obligaciones a las que se está sometido, y el establecimiento de controles externos, casi siempre de naturaleza jurisdiccional, destinados a constatar las violaciones y a sancionarlas. «En el primer caso, el funcionamiento será el resultado de las constricciones, aquí de la sumisión a una obligación» (Troper, 1999, p. 337).

166 Como escribe M. Troper, «ninguna de las concepciones que se acaban de describir ha reinado nunca sola. Por un lado, una constitución inspirada por la concepción mecanicista está necesariamente redactada bajo la forma de enunciados normativos, susceptibles de ser entendidos como imponiendo obligaciones jurídicas. Por otro lado, los que redactan una constitución basada en la concepción normativa no pueden evitar interrogarse sobre las razones que pueden incitar a los poderes públicos a someterse a las obligaciones y raramente toman en cuenta solamente la buena fe de los hombres» (Troper, 1999, p. 340).

167 En un sentido similar, J. Aguiló señala que dentro del constitucionalismo como ideología pueden distinguirse dos grandes concepciones relativas a la eficacia de la constitución, es decir, relativas a cómo hacer efectivos los valores e ideales del constitucionalismo moderno. «Hay concepciones del constitucionalismo que se muestran escépticas hacia el papel regulativo (de guía de la conducta, de imposición de deberes) que pueda desempeñar la Constitución. Estas concepciones tienden a pensar que la eficacia de la constitución (la efectividad de esos valores y fines) depende centralmente de un correcto diseño de las formas de acción jurídica y política y, en consecuencia, han puesto el énfasis en la dimensión constitutivas de las constituciones: las formas de acción política y jurídica tiene que ser correctas, equilibradas (pesos y contrapesos), compensatorias de pasiones, deliberadamente idóneas, etc. Han puesto el acento en la división de poderes, la inamovilidad de los jueces, la legalidad de la administración, el imperio de la ley, la regla de las mayorías, etc. Frente a estas corrientes, hay otro gran grupo de concepciones que, por el contrario, han pensado que la eficacia de la Constitución (es decir, de los valores y fines del constitucionalismo) no depende sólo ni fundamentalmente de las formas de acción política y jurídica creadas por la Constitución, que no es una cuestión de diseños institucionales "perfectos", pues la desviación siempre es posible. En consecuencia, han enfatizado la traducción de los valores y los fines en deberes, afirmando una dimensión regulativa de la Constitución. De forma que la eficacia de la Constitución dependerá centralmente-como ocurre con cualquier norma de conducta- de la adaptación de la conducta y de los controles frente 
Lo interesante de esta diferenciación es que la concepción normativa de constitución se lleva hasta sus últimas consecuencias. La constitución no es sólo una norma que establece una estructura de organización del poder político. Es sobre todo una norma suprema cuyos contenidos, sin importar si se ocupan o no de las instituciones estatales, se imponen y definen los contenidos de las demás normas del ordenamiento. Esto se garantiza mediante el establecimiento de mecanismos y procedimientos a través de los cuales se determina si el derecho inferior es contrario al constitucional, se declara que esta situación es antijurídica y, por ende, se procede a dejar sin aplicación las normas inconstitucionales o incluso a expulsarlas del sistema, perdiendo así su validez. Aunque el carácter jurídico de la constitución se acentúa de esta manera, su sentido político no queda necesariamente formalizado y neutralizado. Si la organización de los poderes públicos corresponde a la prevista por la constitución, pero los diferentes tipos de normas que ellos promulgan no deben ajustarse necesariamente a las disposiciones constitucionales, no es posible en este caso afirmar que la constitución es una norma suprema. Si, por el contrario, todas sus disposiciones son igualmente obligatorias la constitución tiene una posición de supremacía que puede reforzarse a través de garantías de tipo jurídico, como la que acaba de indicarse, que pueden ponerse además en cabeza de los órganos judiciales ${ }^{168}$. Que la constitución rija como una norma obligatoria es un medio para alcanzar el objetivo que se propone en el «concepto mínimo» de constitución, consistente en controlar y limitar el ejercicio del poder, porque «si la Constitución tiene realmente ese valor supremo, forma parte de su ser mismo la imposición de algún límite, esto es, de prohibiciones y

a la desviación. (...) El constitucionalismo de los diseños institucionales justifica las diferentes formas de acción jurídica y política creadas por su idoneidad para asegurar los valores y los fines; y el constitucionalismo regulativo no ve los deberes constitucionales como mera imposición política, sino que los ve en una conexión justificativa con esos valores y fines» (Aguiló, 2004a, pp. 48-49).

168 Por esta razón para N. Matteucci hay una característica de la evolución del constitucionalismo (de la que nos ocuparemos a continuación) que es esencial para la realización del principio del gobierno limitado: «ésta es la más importante de todas, porque hace eficaz la supremacía de la ley, o mejor dicho de la constitución. Se trata del poder judicial en su conjunto (...) o de una corte judicial, la cual además de resolver los eventuales conflictos entre los diversos órganos del Estado controla la justicia de la ley, es decir su conformidad a las normas fundamentales. La existencia de este órgano es esencial, pues de otra manera, contra la violación de la constitución por parte del gobiernomayoría, no habría ningún remedio, a no ser un abstracto derecho a la revolución o una hipotética posibilidad de recurrir a la fuerza» (Matteucci, 2005, p. 346). 
mandatos, pues de otro modo difícilmente cabrá hablar de norma» (Otto, 1999, p. 19). Cuando los textos constitucionales se ocupan principalmente de las competencias y los procedimientos de los órganos superiores del Estado, se restringe bastante su capacidad de determinar el contenido de las normas jurídicas. De otra forma, cuando los contenidos sustantivos, que se plasman en valores y principios constitucionales, se imponen con el mismo grado de obligatoriedad que los contenidos formales, e incluso cuando los primeros se refuerzan normativamente al presentarse como el fundamento de legitimidad del ordenamiento jurídico y del régimen político, se reconoce a la constitución como la norma suprema en el sentido de estar por encima de la ley y de las demás normas jurídicas. Este es precisamente el proceso que ha caracterizado la transición del «Estado de derecho» del siglo XIX y comienzos del XX al «Estado constitucional» posterior a la Segunda Guerra Mundial.

3.

\section{EL CONSTITUCIONALISMO}

Como ocurre con el concepto de constitución, el concepto de constitucionalismo no sólo se caracteriza por su ambigüedad, por la variedad de significados que ha tenido. Ha habido también cierta indeterminación en cuanto a su referente, pues con este concepto se alude, entre otras cosas, a un «principio general» (McIlwain, 1991, p. 15), a una «técnica» (Friedrich, 1975 , t. I, p. 18), a un «régimen político» (Raynaud, 2003, p. 266), a una «cultura» (Clavero, 1998, p. 11), a unas «doctrinas» (Fioravanti, 2001, pp. 12 y 85), a un «movimiento ideológico y político» (Otto, 1999, p. 12), a una «ideología» (Comanducci, 2003, pp. 76 y 82), e incluso a la «confianza» (trust) en el poder de las palabras puestas por escrito para mantener a raya el gobierno (Hamilton, 1959, p. 255). Ahora bien, estos referentes tienen en común que están vinculados con la implantación, la estructuración y la fundamentación del poder político en las sociedades humanas. Teniendo esto en cuenta, si se quiere dar una definición amplia y comprensiva de todos ellos es posible afirmar que el constitucionalismo es una «reflexión» que se ocupa de «la experiencia político-jurídica relativa a la organización del poder» (Matteucci, 1998, p. 23), experiencia que, en este contexto, se designa con el término «constitución», ya sea en un sentido factico o en un sentido normativo ${ }^{169}$. Con todo, con constitucionalismo también se designa al

169 Como «reflexión», entonces, el constitucionalismo tiene como objeto principal la organización del poder, esto es, las normas jurídicas y las estructuras institucionales 
objeto de esa reflexión, es decir, a los elementos estructurales de un sistema jurídico y político que son descritos, explicados y respaldados por aquella (Comanducci, 2003, p. 75).

En cuanto reflexión, el constitucionalismo puede tener como objeto el poder político efectivamente existente o la constitución efectivamente vigente, de manera que puede identificarse un constitucionalismo descriptivo que se limita hacer juicios sobre la realidad constitucional de una sociedad asumiendo una postura neutra frente a ésta (Troper, 1994, p. 209). Pero, por otra parte, también es posible reconocer un constitucionalismo prescriptivo, que no se queda en describir lo que existe, sino que propone un modelo ideal de gobierno que hay que alcanzar y que le permite diferenciar los regímenes constitucionales de los que no lo son. Ese modelo ideal responde a ciertos valores éticos, a cierta forma de legitimación del poder y a ciertos fines de la sociedad que hacen que en este tipo de constitucionalismo el lugar que ocupa la ideología político-jurídica sea central, mientras que en el otro sus pretensiones de lograr un conocimiento neutro de la constitución descartan esa clase de consideraciones. Si se asume la concepción valorativa o prescriptiva, el constitucionalismo como reflexión hunde sus raíces en el pasado, porque la preocupación por el gobierno ideal desde siempre se ha hecho presente en la historia del pensamiento político-jurídico. Por su parte, la aparición de un constitucionalismo descriptivo está íntimamente relacionada con la formalización del derecho constitucional que se produjo desde finales del siglo XVIII, con las primeras constituciones escritas en sentido moderno, y que se acentuó a lo largo del siglo XIX. A pesar de esto, hay una arraigada tendencia en el constitucionalismo a ir más allá de la constatación de la realidad constitucional y a proponer alternativas a lo que existe ${ }^{170}$. Este es el motivo por el cual se hace necesario identificar ese

mediante las cuales se realiza determinado ideal político. En otras palabras, el constitucionalismo se preocupa principalmente por la realización efectiva en una sociedad humana de una concepción sobre el poder y su legitimidad. Esto permitiría hacer una diferenciación parcial con la filosofía política, que se ocuparía precisamente de estas concepciones. Sin embargo, no es esta una distinción tajante porque el constitucionalismo no deja de lado las cuestiones sobre la fundamentación del poder político y, a su tuno, desde la filosofía política se han propuestos modelos jurídicos y constitucionales de realización de determinado ideal sobre el poder. Por consiguiente, la diferencia entre ambos ámbitos es de grado.

170 A este nivel se plantea la distinción entre un «constitucionalismo reformista», que reclama al poder existente conceder o pactar la promulgación de una constitución, y un «constitucionalismo revolucionario», que propone destruir el poder existente 
componente material, ese modelo ideal de gobierno, que está en la base de su evolución.

No son pocos los que lo identifican con la división o separación de poderes, postura que tiene su fundamento histórico en el artículo 16 de la declaración de derechos de 1789 que ya se ha citado antes. En este sentido se afirma que el constitucionalismo supone «el reparto del ejercicio del poder», esto es, «un sistema de frenos eficaces a la acción del gobierno» a través de «métodos y técnicas que permiten establecer y mantener estos frenos» (Friedrich, 1975, t. I, p. 19). Sin embargo, la separación de poderes, en particular en las democracias contemporáneas, no es suficiente para impedir el arbitrio de una mayoría que llegue a dominar las instituciones estatales. Como lo explica N. Matteucci, «la actual división de órganos puede obstaculizar o disminuir la voluntad de un partido fuerte o de una mayoría estable, pero es totalmente insuficiente para garantizar tanto los derechos de las minorías como impedir el abuso del poder respecto de los ciudadanos, en la medida en que estos órganos pueden estar en manos del mismo partido» (Matteucci, 2005, p. 342). Por consiguiente, la separación de poderes es más bien un mecanismo institucional para lograr el principal propósito que se ha trazado el constitucionalismo en su larga historia, que C. H. McIlwain ha identificado en estos términos:

«El constitucionalismo tiene una esencial cualidad: implica una limitación jurídica del gobierno; es la antítesis del gobierno arbitrario; es lo contrario del gobierno despótico, del gobierno del capricho en vez del derecho. (...) El rasgo característico más antiguo, Constante y duradero del verdadero constitucionalismo continúa siendo, como lo ha sido casi desde el comienzo, la limitación del gobierno por el derecho. "Las limitaciones constitucionales" si no la más importante parte de nuestro constitucionalismo, son, fuera de duda, la más antigua» (McIlwain, 1991, p. 37).

Así pues, ante la alternativa entre el gobierno de los hombres y el gobierno de las leyes (de la que nos ocuparemos más adelante), el constitucionalismo siempre ha defendido la segunda opción. Esto explica su profundo vínculo no sólo con la política sino también con el derecho ${ }^{171}$. Por lo tanto, el

y exigir al nuevo poder revolucionario la promulgación de una nueva constitución (Comanducci, 2003, p. 78).

171 Por eso, para O. Beaud, «si el constitucionalismo procede indudablemente de la filosofía política liberal, su especificidad proviene del hecho de que la limitación del poder político que persigue se realiza por medio del derecho, por medio de la constitución 
constitucionalismo, como reflexión o como objeto de esta reflexión, se concreta en «la práctica de la política conforme a unas "reglas de juego" que imponen limitaciones efectivas a la acción del gobierno y de otras fuerzas políticas, y la teoría -explicativa y justificativa-de tal práctica» (Friedrich, 1974, p.79). Quienes defienden esta postura, los constitucionalistas, son «escritores ligados de manera activa a la política», pero que también confían «en el derecho para institucionalizar y para dirimir los conflictos y subordinar la fuerza a un principio superior» (Matteucci, 1998, p. 24). Por lo tanto, el constitucionalismo se ha caracterizado por su propósito de realizar el ideal del gobierno limitado por el derecho. Este ideal se ha planteado tanto respecto del poder político en la Ciudad-Estado, siendo éste el objeto del «constitucionalismo antiguo» ${ }^{172}$, como frente al poder de la monarquía feudal, con base en lo cual se desarrolló un «constitucionalismo medieval». Con todo, al igual que sucede con el concepto de constitución, las trasformaciones del derecho y de las instituciones dieron lugar al surgimiento de un «constitucionalismo moderno», que propende por la limitación del poder político que ahora ejerce el Estado-nación. A diferencia de lo que ocurría bajo las estructuras políticas feudales, al Estado se le reconoce el poder de disponer del derecho, creando uno nuevo o modificando el existente, poder que se sintetiza en el concepto de soberanía. El constitucionalismo moderno asume entonces ante el Estado soberano un doble vínculo: por un lado, el constitucionalismo cambia sus propuestas sobre el control jurídico del poder cuando éste se concentra y unifica bajo el Estado, que abandona así el modelo disperso y fragmentado del régimen medieval ${ }^{173}$; por otro lado,

concebida como jurídica. (...) Como el derecho moderno tiende a la norma jurídica, el constitucionalismo moderno tiende también a la constitución-norma, como así lo indican las definiciones usuales de constitución» (Beaud, 2003, p. 134).

172 En el denominado «constitucionalismo antiguo» suele distinguirse el modelo griego, cuya principal elaboración doctrinal fue la politeia de Aristóteles, y el modelo romano del periodo de la república (508-27 a. C.), que fue objeto de análisis por parte de Polibio (208?-126? a. C.), en el libro sexto de sus Historias (Polibio, 1983), y de Cicerón, en sus dos principales obras, De re publica y De legibus (Cicerón, 1992). Dados los límites del presente trabajo no nos hemos ocupado de este tipo de constitucionalismo, aunque puede hacerse referencia a los siguientes trabajos: Aalders (1968); Everson (1996); Fioravanti (2001, pp. 15-31); Finer (1997, p. 66); Friedrich (1974, pp. 79-80); Fritz (1975); Lintott (1999); Mcilwain (1991, pp. 39-87); Nippel (1980).

173 En este sentido, como lo explica D. Grimm, «con anterioridad a la reunión de los derechos de soberanía dispersos y a su concentración en el poder estatal pleno (...), no había posibilidad de que existiera constitución moderna alguna». Por consiguiente, uno de los presupuestos de su surgimiento fue «la construcción de un 
el constitucionalismo no sólo se desarrolla contra el Estado moderno y sus nuevas modalidades de ejercicio del poder, sino también dentro del Estado, en la medida en que el concepto de constitucionalismo moderno implica el de soberanía del Estado. Esto en razón a que el constitucionalismo «busca limitar el poder del Estado por medio de "reglas intangibles", denominadas "constitucionales", que están fuera del alcance de los gobernantes. En concreto, el nacimiento de la constitución moderna muestra el esfuerzo dirigido a sustraer una parte del derecho positivo de la voluntad de los gobernantes, a favor de la defensa de los derechos de los ciudadanos» (Beaud, 2003, p. 134). La historia del constitucionalismo moderno muestra su escepticismo y desconfianza frente a la noción de soberanía (Troper, 1994, p. 207), pero si ésta no hubiera surgido y no se hubiera atribuido al Estado moderno no se habría dado una de las condiciones para que aquel hubiese estructurado sus formas peculiares de fundamentación y control del poder ${ }^{174}$.

Los nuevos mecanismos de limitación al poder que propuso el constitucionalismo moderno frente a un Estado que pretendía ser soberano se sintetizan en la formalización del derecho constitucional en un documento escrito. Nada mejor frente a un poder con mayores posibilidades de desbordar sus fines y competencias que fijar los límites de su acción de manera clara y precisa en un documento al que todos pueden acceder, en un «código» constitucional ${ }^{175}$, de manera que esta formalización surge principalmente

objeto constitucionalmente regulable bajo la forma de un poder estatal diferenciado y unitario» (Grimm, 2006b, pp. 51 y 61).

174 En palabras de H. Heller, «si, en último extremo, todos los habitantes del territorio deben estar sometidos mediata o inmediatamente a la unidad fundamental de la decisión y todos deben también contribuir a la unidad de la acción central, es necesario que la organización total tenga un plan unitario, una Constitución normativa. (...) La tendencia a la racionalización de la estructura de poder, junto con los esfuerzos revolucionarios de la burguesía tendientes al establecimiento de límites jurídicos al ejercicio de poder del Estado, han influido en la creación de las modernas Constituciones» (Heller, 1942, pp. 290-291).

175 Así, en términos de P. L. Verdú (1997, p. 43), «tener una constitución», contar con una constitución formalizada, es uno de los medios para «vivir en constitución», para que los ideales, esto es, los valores y fines del constitucionalismo se realicen en la práctica. Es más, el constitucionalismo moderno puede definirse como la «ideología política que ha propugnado "darse una Constitución" (una Constitución rígida o formal) como garantía de "vivir en Constitución" (de la práctica de esos ideales)» (Aguiló, 2004a , p. 43). Es por este motivo, como lo explica J. Aguiló, que la constitución formalizada, como mecanismo para limitar el poder propuesto por el constitucionalismo moderno, «no sólo "crea" cosas, sino también "reconoce" cosas; o lo que es lo mismo, además 
como un medio para lograr el objetivo de garantizar un gobierno limitado ${ }^{176}$. Como ya tuvimos ocasión de señalar al ocuparnos del «concepto mínimo» de constitución, los límites y controles que contiene la constitución escrita propuesta por el constitucionalismo moderno se concretan en los derechos fundamentales y en la separación o distribución de los poderes, de manera que la legitimidad de la constitución se basa en la justicia y racionalidad del contenido de sus normas ${ }^{177}$. Ahora bien, la constitución es legítima además por otro motivo: por su origen, «por emanar de la voluntad soberana del pueblo a través de una asamblea constituyente y, a veces, de un referéndum; por el contrario, en la Edad Media era el pasado, la tradición, la fuente de la legitimidad unida a la razón y a la voluntad de Dios» (Matteucci, 1998, p. 25). Por lo tanto, la formalización del derecho constitucional no sólo sirve al propósito de imponer restricciones jurídicas al poder, sino también al de introducir una concepción voluntarista de la constitución ${ }^{178}$. Con esto se

de una dimensión constitutiva, tiene una dimensión valorativa. (...) Las constituciones no sólo tienen esa dimensión constitutiva, no sólo crean órganos y procedimientos, sino que además tienen una dimensión valorativa, reconocen estados de cosas valiosos y, por tanto, merecedores de ser protegidos o promocionados (es decir, de ser garantizados). (...) En definitiva, las Constituciones reconocen valores y fines que dotan de sentido a las formas de acción política (órganos y procedimientos) creadas por ellas mismas» (Aguiló, 2004a, pp. 44-46).

176 Teniendo esto en cuenta, es posible imaginar un gobierno constitucional sin constitución escrita, o con una constitución que sólo haya sido parcialmente formalizada. El ejemplo más conocido de esta situación es el de Inglaterra «que ilustra claramente la tesis de que la Constitución formal no es necesaria para la vigencia de los ideales del liberalismo democrático, es decir, que es posible "vivir en Constitución" sin "tener una Constitución”» (Aguiló, 2004a, p. 42). Esta es la razón por la cual G. Sartori asegura que el hecho de que la constitución esté puesta en un documento escrito es algo secundario. «Lo que realmente importa es el fin, el telos. Y el propósito, el telos, del constitucionalismo inglés, estadounidense y europeo era, desde un principio, idéntico. (...) Este propósito común puede expresarse y sintetizarse con sólo una palabra: el término francés (e italiano) garantisme [garantismo]. En otras palabras, la gente de todo el mundo occidental requiere o valora "la constitución", porque este término significa para ellos una ley fundamental o una serie fundamental de principios, que restringen el poder arbitrario y aseguran un "gobierno limitado"» (Sartori, 1962, p. 855).

177 Por esta razón P. Comanducci asegura que el constitucionalismo moderno «es fundamentalmente una ideología, dirigida a la limitación del poder y a la defensa de una esfera de libertades naturales, o de derechos fundamentales», ideología que «tiene como trasfondo habitual, aunque no necesario, el iusnaturalismo» y que «sostiene la tesis de la conexión identificativa entre Derecho y moral» (Comanducci, 2003, p. 82).

178 De acuerdo con H. Heller «esta voluntad consciente para la determinación unitaria del destino político por la sistematización y racionalización de la Constitución jurídica, 
pone de presente otra de las características del constitucionalismo moderno: la de ofrecer un nuevo fundamento de legitimidad del poder político, que abandona las concepciones historicistas y teocráticas, y que lo encuentra en el consentimiento de los gobernados, de los destinatarios del poder, que se expresa mediante un pacto o contrato. Por ende, el constitucionalismo moderno no se contentó "con el cambio de gobernantes y de formas de gobierno», sino que construyó intelectualmente «las condiciones del poder legítimo y [trasladó] esta construcción a normas jurídicas obligatorias» (Grimm, 2006b, p. 46).

En este orden de ideas, el constitucionalismo moderno formula una concepción peculiar sobre el contenido y la estructura de la constitución que, además, tiene un fuerte nexo con el liberalismo político, entre otras razones porque los límites al poder encuentran su justificación en la protección de los derechos y libertades de los individuos que suponen, a su turno, la distinción entre lo público y lo privado, entre el Estado y la sociedad civil, otra de las tesis básicas del liberalismo ${ }^{179}$. Sin embargo, el otro componente del constitucionalismo, el de la legitimidad del poder basada en el consentimiento de los gobernados, fue objeto de crítica no sólo por aquellos que querían un retorno a las anteriores formas de legitimación, sino además por aquellos que querían llevar la tesis del consentimiento hasta sus últimas consecuencias. Los gobernados no debían limitarse a dar su consentimiento, casi siempre de manera tácita, al poder; también debían

y no el hecho de la mera codificación, distingue a los documentos constitucionales modernos desde el siglo XVIII de sus precursores» (Heller, 1942, p. 290).

179 La separación del Estado y la sociedad para el liberalismo suponía que esta última «era capaz de lograr la prosperidad y la justicia con sus propias fuerzas por medio de las decisiones libres de las voluntades individuales, de modo que el Estado podría abandonar su papel de dirección central y limitarse a la función de garantía, cedida por la sociedad, de un orden presupuesto e independiente de él. (...) En la medida en que estas condiciones sólo son aplicables a la burguesía moderna, al modelo social burgués y a la revolución burguesa, la constitución [moderna] puede calificarse como fenómeno burgués» (Grimm, 2006b, p. 61). Por lo demás, este vínculo entre constitucionalismo y liberalismo permite a M. Troper distinguir entre un constitucionalismo lato sensu, que defiende la idea de que todo Estado debe tener una constitución que impida el despotismo, y un constitucionalismo stricto sensu, que además de afirmar que es necesaria una constitución considera que ésta debe fundamentarse en algunos principios destinados a impedir el despotismo y establecer la libertad política. Este autor también propone un concepto de constitucionalismo strictissimo sensu, que defiende la figura del control judicial de la constitucionalidad de la leyes como mecanismo para alcanzar los propósitos del_constitucionalismo stricto sensu (Troper, 1994, pp. 203-204). 
participar directamente en su ejercicio, razón por la cual no se justificaban las restricciones al voto que el liberalismo clásico quiso defender afirmando que los únicos que podían participar en el proceso político eran aquellos que tenían las condiciones materiales e intelectuales para hacerlo ${ }^{180}$. Ello supuso la renovación de la noción de soberanía que ya no estará en cabeza del rey como personificación del Estado (como creía Thomas Hobbes) sino en cabeza de los miembros de la comunidad, del pueblo (como creía JeanJacques Rousseau). A pesar de esto, las diferencias de esta concepción con la del constitucionalismo moderno se mantienen, pues supone un soberano que dispone del derecho y que no tiene límites jurídicos. Se presenta así una tensión entre «el ideal de un proceso político participativo en el que toda la gente afectada por ese proceso tiene intervención en esa decisión, y el ideal liberal de un gobierno limitado, según el cual aún la mayoría debe detenerse frente a intereses protegidos» (Nino, 1992, p. 4). Con todo y pese a los enfrentamientos que de hecho se dieron entre ellos, no son dos tendencias que inevitablemente se contradicen, pues hay manera de armonizarlas. Es así como «la libertad positiva de participar en la formación de la voluntad del Estado tiene, como necesaria condición, la libertad negativa, es decir el no impedimento por parte del Estado de los derechos de libertad de expresión, de imprenta, de asociación, de religión, etc., porque de otra forma irían desapareciendo las condiciones mismas de una autónoma participación en la formación de la voluntad del Estado, como sucede en los regímenes totalitarios» (Matteucci, 2005, p. 348). La articulación de las dos concepciones dio lugar a la formación, desde finales del siglo XIX y sobre todo durante el siglo XX, de una «democracia liberal o constitucional», de un «constitucionalismo democrático», que «no es otra cosa que el modo concreto a través del cual se ejerce y se realiza un sistema democrático representativo» (Matteucci, 2005, p. 348) ${ }^{181}$.

180 Como lo ha puesto de presente K. Löewenstein, durante el siglo XIX «las constituciones funcionaron bien en la medida en que la competición por el poder estaba confinada en diferentes grupos de la misma clase social; pero fueron llevadas al límite, y a menudo se rompieron, cuando sus reglas se hicieron insuficientes para acomodarse a las ambiciones de poder de las clases excluidas según sus mismas reglas» (Löewenstein, 1951, p. 197).

181 A pesar de estos intentos de articulación, las relaciones entre constitucionalismo y democracia no dejan de ser complejas e inestables. De hecho, este es uno de los elementos que mayor debate ha generado en el análisis constitucional contemporáneo. A este respecto es posible identificar una concepción procedimental frente a una concepción sustantiva de la constitución. «En general, el procedimentalismo 
No obstante, las exigencias al constitucionalismo no se quedaron únicamente en el plano de la apertura democrática. Las trasformaciones de la sociedad industrial en la segunda parte del siglo XIX y las consecuencias que tuvieron en la ampliación de la desigualdad en las condiciones materiales de vida, impedían mantener de manera rígida la separación entre sociedad y Estado ${ }^{182}$. Se comenzó a reclamar entonces que este último cumpliera con una serie de funciones nuevas que suponían la superación del modelo del liberalismo clásico que encontraba en la pasividad de las autoridades no un defecto sino una virtud. Este nuevo reto al constitucionalismo suponía que el modelo ideal de gobierno no podía restringirse al establecimiento de límites jurídicos al poder del Estado. Se requería igualmente que éste asumiera una serie de tareas dirigidas al logro de una sociedad más igualitaria, tanto en términos políticos como en términos materiales. Por paradójico que

constitucional se caracteriza por sostener que el tema central de una constitución es establecer procedimientos justificados conforme a ciertos valores (...) y que los únicos límites normativos que pueden ponérseles a los resultados de esos procedimientos (si es que pueden ponerse algunos) tienen que ver con la conservación y el perfeccionamiento del propio procedimiento justificado. El procedimentalismo democrático aceptará exclusivamente límites normativos destinados a conservar y perfeccionar el procedimiento democrático, pero no límites sustantivos. (...) Frente a ello, el sustantivismo -como corriente opuesta- propondrá diseños constitucionales y lecturas constitucionales que sí le impongan límites normativos a la acción política y que están más allá de la simple protección del procedimiento considerado justificado»» (Aguiló, 2004b, pp. 87, 89-90). Entre los autores representativos de la segunda concepción se destaca R. Dworkin (1995, pp. 36-37, 159, 302-303), aunque también puede mencionarse a L. Ferrajoli (1998, pp. 931-933), mientras que representantes de la concepción procedimental son, entre otros, J. H. Ely (1997, pp. 128-131) y J. Habermas (1998, pp. 311-361). Es más, hay quienes han llevado esta concepción hasta sus últimas consecuencias para plantear una crítica frontal al constitucionalismo. Así lo hace, por ejemplo, J. Waldron, para quien, siendo la democracia la teoría de la legitimidad del poder político mejor justificada, no tiene sentido imponerle límites jurídico-institucionales, como los del control judicial de la constitucionalidad de las leyes (Waldron, 1993). Para una revisión de este debate puede consultarse: Bayón (2003, pp. 211-227); Elster (1999, pp. 33-45); Ferreres Comella (2007, p. 23); Sunstein (1999, pp. 364-368).

182 Resultado de este fenómeno, como lo explica K. Hesse, es que los presupuestos de ese dualismo desaparecerán en el Estado democrático y social contemporáneo. «La vida "social" ha dejado de ser posible sin una organización responsable, organizadora y planificadora. A la inversa, el "Estado" democrático no se constituye sino a través de la cooperación social. (...) La importancia actual del Estado para la vida económica y social, así como la influencia "social" sobre la actividad estatal e, incluso, la participación "social”" en aquel excluyen una contraposición carente de relación alguna» (Hesse, 1992, p. 12). 
parezca al tiempo que se le exigía no rebasar ciertos límites, al Estado se le reclamaba también que cumpliera ciertas tareas. De esta manera desde el periodo de entreguerras surge una nueva versión del constitucionalismo, que sin abandonar los elementos liberales de la versión anterior, quería responder a las reivindicaciones por la igualdad tanto política como socioeconómica. Este «constitucionalismo social», sin embargo, se enfrenta a una enorme dificultad: el constitucionalismo moderno había encontrado en las normas jurídicas formalizadas en el texto constitucional un mecanismo relativamente eficaz de control y límite al poder. Ahora bien, ¿son igualmente eficaces las normas jurídicas cuando se trata de impulsar la realización de tareas materiales de gobierno? Aunque estas tareas pueden establecerse y dirigirse mediante normas, su cumplimiento y realización depende de numerosos factores de hecho, como las condiciones económicas, el consenso que las medidas generan, el contexto socio-cultural, etc. Como lo destaca D. Grimm, «esto comporta consecuencias para la constitución, puesto que no está adaptada a la solución de problemas materiales ni puede adaptarse a esa función sin problemas. La fuerza regulatoria de la constitución se hundió como consecuencia de la reorganización del orden estatal liberal en el moderno Estado de bienestar» (Grimm, 2006b, p. 73) ${ }^{183}$. Es éste entonces uno de los más difíciles retos que debe afrontar el constitucionalismo después del siglo XX, que pretende imponer límites jurídicos al poder pero además impulsar, a través del derecho constitucional, el progreso de la sociedad y la trasformación de sus estructuras sociales y económicas. En otras palabras, se requiere de un constitucionalismo que «mantenga un equilibrio entre el poder gubernamental y su control, sin disipar ese poder hasta tal punto que el gobierno se haga débil e indiferente. (...) En este caso "la constitución" es legítimamente "un marco" de la asociación política tan estructurado como para contener el poder gubernamental dentro de sus precisas competencias,

183 K. Löewenstein también ha destacado las dificultades que tiene el constitucionalismo para responder a las reivindicaciones a favor de una sociedad más igualitaria: «la masa del pueblo es lo suficientemente lúcida para reclamar un mínimo de justicia social y de seguridad económica. Pero ni la más perfecta Constitución está en situación de satisfacer estos deseos, por más pretencioso que pueda ser el catálogo de Derechos Fundamentales económicos y sociales. La Constitución no puede salvar el abismo entre pobreza y riqueza; no puede traer ni comida, ni casa, ni ropa, ni educación, ni descanso, es decir las necesidades esenciales de la vida. En aquellos países occidentales donde la sociedad estatal puso proa hacia el Estado de bienestar -y esto es hoy el caso por todas partes-, este rumbo no se tomó por obra de la Constitución, cuyo liberalismo se oponía a esta política, sino a pesar de la Constitución y fuera de ella» (Löewenstein, 1983, p. 229). 
pero permitiéndole existir con el suficiente alcance para proteger $\mathrm{y}$, donde sea posible, elevar las expectativas del pueblo» (Maddox, 1989, p. 64).

El término «neoconstitucionalismo» ha servido para sintetizar el resultado actual de la evolución que se viene describiendo. Con él se hace referencia, en primer lugar, a «un conjunto de textos constitucionales que comienzan a surgir después de la segunda guerra mundial (...). Se trata de Constituciones que no se limitan a establecer competencias o a separar a los poderes públicos, sino que contienen altos niveles de normas "materiales" o sustantivas que condicionan la actuación del Estado por medio de la ordenación de ciertos fines y objetivos. Ejemplos representativos de este tipo de Constituciones lo son la española de 1978, la brasileña de 1988 y la colombiana de 1991» (Carbonell, 2007, p. 9-10). Sin embargo, como sucede con el término «constitucionalismo», con el de «neoconstitucionalismo» igualmente se designa, por un lado, una «reflexión» sobre la realidad constitucional y, por el otro, una forma peculiar como esta misma realidad se configura. En esta segunda acepción, el neoconstitucionalismo es un modelo constitucional que integra algunos aspectos del constitucionalismo moderno clásico pero que se distancia de éste en varios otros. Entre estos últimos está su pretensión de completar la legitimación democrática mediante la eliminación de las restricciones que pesaban sobre los derechos de participación política y, además, su propósito de que el derecho constitucional sea el marco jurídico-institucional que garantice un nivel mínimo de igualdad en las condiciones de vida de las personas, a través del reconocimiento de derechos sociales y económicos y de la intervención del Estado en la economía y en otros aspectos de la sociedad. Este modelo, que ha recibido entre otras denominaciones la de «Estado constitucional de derecho» o la de «Estado social y democrático de derecho» ${ }^{184}$, es, por ende, «un resultado

184 En una de sus decisiones más conocidas, la Corte Constitucional colombiana ha indicado que «el término "social”, ahora agregado a la clásica fórmula del Estado de Derecho, no debe ser entendido como una simple muletilla retórica que proporciona un elegante toque de filantropía a la idea tradicional del derecho y del Estado. Una larga historia de transformaciones institucionales en las principales democracias constitucionales del mundo, está presente para dar testimonio de la trascendencia de este concepto». «La incidencia del Estado social de derecho en la organización sociopolítica puede ser descrita esquemáticamente desde dos puntos de vista: cuantitativo y cualitativo. Lo primero suele tratarse bajo el tema del Estado bienestar (welfare State, stato del benessere, l'Etat Providence) y lo segundo bajo el tema de Estado constitucional democrático. La delimitación entre ambos conceptos no es tajante; cada uno de ellos hace alusión a un aspecto específico de un mismo asunto. Su complementariedad es evidente» (Sentencia T-406 de 1992, M.P. Ciro Angarita Barón). 
complejo, a veces contradictorio, de tres tradiciones diversas, que en cierta medida representan los diferentes componentes ideológicos y los principios constitutivos de este tipo de Estado» (Uprimny, 1997, p. 116-117) ${ }^{185}$ : de un lado, es un Estado liberal, que recoge las aspiraciones del modelo clásico del Estado de derecho del siglo XIX, en particular las limitaciones al poder mediante mecanismos como la separación de poderes y el establecimiento de libertades, definidas como la ausencia de interferencias en la autonomía individual; de otro lado, es un Estado democrático que se fundamenta en la soberanía popular y en la igual participación de todos en el diseño de las instituciones y en la formación de la voluntad política, razón por la cual la libertad es entendida como la facultad de participar en los destinos colectivos del orden político; finalmente, es un Estado social que reposa en la idea de que el poder político debe lograr para los asociados una justicia material mínima, de suerte que la democracia es entendida más como el efecto material del ejercicio del poder, como una cierta igualdad social conseguida a través de la acción estatal, al tiempo que las libertades se conciben como el resultado de las prestaciones positivas de parte del Estado ${ }^{186}$.

185 El propósito de integrar diversas tradiciones filosófico-políticas hace que en el modelo constitucional contemporáneo se rompa la unidad ideológica que caracterizaba al constitucionalismo liberal clásico. Por este motivo, mientras que en este último se partía del consenso en torno a unos principios coherentes entre sí, en aquel el presupuesto es la existencia de diversas opciones políticas que la constitución pretende integrar para generar consensos mínimos. Mientras que en el modelo clásico el consenso se presupone al derecho constitucional, en el «neoconstitucionalismo» el consenso es el producto del proceso político que da lugar a la constitución y que, una vez establecida, ésta busca regular. El conflicto, entonces, no es visto como un elemento de desintegración sino como una característica del dinamismo constitucional. En palabras de K. Hesse, aunque la constitución persigue la unidad política del Estado, esto «no significa la producción de un armónico estado de coincidencia general y en cualquier caso no la eliminación de las diferencias sociales, políticas o de tipo institucional y organizativo a través de la nivelación total. Dicha unidad no resulta imaginable sin la presencia y relevancia de conflictos en la humana convivencia. (...) Ahora bien, no sólo importa que haya conflictos sino también que éstos vengan regulados y resueltos. (...) Por ello la cuestión no es tanto la de dar cabida al conflicto y a sus efectos como la de garantizar (...) la formación y el mantenimiento de la unidad política, sin ignorar o reprimir el conflicto en nombre de la unidad política y sin sacrificar la unidad política en nombre del conflicto» (Hesse, 1992, p. 9).

186 En un sentido similar, L. Prieto Sanchís define el neoconstitucionalismo como un modelo en el que convergen dos tipos de tradiciones constitucionales: «la tradición norteamericana originaria, cuya contribución básica se cifra en la idea de supremacía constitucional y en su consiguiente garantía jurisdiccional», y la tradición que concibe la constitución como «la encarnación de un proyecto político (...), como el 
Por otra parte, el neoconstitucionalismo como una forma de concebir o reflexionar sobre un determinado modelo constitucional puede escindirse, como lo hace P. Comanducci, en tres tipos (Comanducci, 2003, pp. 82-87). En primer lugar, el neoconstitucionalismo como teoría del derecho, que representa una alternativa a la teoría del positivismo jurídico tradicional y que responde a las profundas trasformaciones que han experimentado los sistemas jurídicos contemporáneos gracias a la implantación del modelo constitucional que se acaba de describir. Esto supone, por un lado, un cambio en la forma como se concibe el derecho, que según Luis Prieto Sanchís, tiene ahora cinco características básicas: «más principios que reglas; más ponderación que subsunción ${ }^{187}$; omnipresencia de la Constitución en todas las áreas jurídicas y en todos los conflictos mínimamente relevantes (...); omnipotencia judicial en lugar de autonomía del legislador ordinario; $y$, por último, coexistencia de una constelación plural de valores, a veces tendencialmente contradictorios, en lugar de homogeneidad ideológica en torno a un puñado de principios coherentes entre sí (...)» (Prieto Sanchís, 2003, p. 131-132 $)^{188}$. Ahora bien, el neoconstitucionalismo teórico también supondría, por otro lado, una renovación epistemológica del conocimiento sobre el derecho, frente a la visión cientificista del positivismo jurídico. Esta renovación implica que la ciencia jurídica no se limita a explicar un fenómeno jurídico sino que también lo crea, combinando una función contemplativa con una creativa (Carbonell, 2007, p. 11). De esta forma nos acercamos al segundo tipo de neoconstitucionalismo, el metodológico, que se contrapone

programa directivo de una empresa de transformación social y política» y que tiene su origen en la Revolución francesa. «El neoconstitucionalismo reúne elementos de estas dos tradiciones: fuerte contenido normativo y garantía jurisdiccional. De la primera de esas tradiciones recoge la idea de garantía jurisdiccional y una correlativa desconfianza ante el legislador; cabe decir que la noción de poder constituyente propia del neoconstitucionalismo es más liberal que democrática (...). De la segunda tradición se hereda, sin embargo, un ambicioso programa normativo que va bastante más allá de lo que exigiría la mera organización del poder mediante el establecimiento de reglas de juego. En pocas palabras, el resultado puede resumirse así: una Constitución transformadora que pretende condicionar de modo importante las decisiones de la mayorías, pero cuyo protagonismo fundamental no corresponde al legislador, sino a los jueces» (Prieto Sanchís, 2003, pp. 125-127).

187 Sobre las consecuencias del neoconstitucionalismo en la interpretación constitucional, véase: Comanducci (2007, pp. 60-65).

188 Caracterizaciones similares de la concepción del derecho que supone el neoconstitucionalismo pueden encontrase en: Alexy (1994, pp. 159-174); Comanducci (2003, p. 83); Guastini (2003, pp. 50-58); Zagrebelsky (1995b, pp. 109-126). 
a la tesis del positivismo según la cual siempre es posible describir el derecho como es realmente y distinguirlo del derecho como debería ser, en tanto que los principios constitucionales y los derechos fundamentales implican una conexión, ya sea necesaria o justificativa, entre derecho y moral. Finalmente, el neoconstitucionalismo se presenta como una ideología, que es parcialmente diferente de la del constitucionalismo moderno de los siglos XVIII y XIX, porque además de limitar el poder estatal, pone en primer lugar el objetivo de garantizar los derechos fundamentales, incluso frente a actores no estatales. «El cambio de acento es fácilmente explicable por el hecho de que el poder estatal, en los ordenamientos democráticos contemporáneos, no es más visto con temor y sospecha por la ideología neoconstitucionalista, que más bien se caracteriza justamente por su apoyo a ese modelo de Estado constitucional y democrático de Derecho» (Comanducci, 2003, p. 85) ${ }^{189}$. De todas maneras, el neoconstitucionalismo no deja de afirmar que «la Constitución pretende limitar el poder estatal y preservar de un abuso de este poder. En esta su función de posibilitar y garantizar un proceso político libre, de construir, de estabilizar, de racionalizar, de limitar el poder y en todo ello de asegurar la libertad individual estriba la cualidad de la Constitución»(Hesse, 1992, p. 21).

4.

CONSIDERACIONES FINALES: LA CONSTITUCIÓN, ENTRE EL DERECHO Y LA POLÍTICA

Con fundamento en las anteriores consideraciones conviene adoptar un concepto amplio de constitución que permita incluir las diversas visiones jurídicas, sociales y políticas asociadas con el mismo. Esto permite de igual forma observar la manera como han cambiado los usos de los términos constitución y constitucionalismo a lo largo de la historia ${ }^{190}$. Además,

189 Esto explica también que los alcances del concepto de constitución frente al Estado hayan cambiado para el neoconstitucionalismo. Por ejemplo, K. Hesse la define como «el orden jurídico fundamental de la Comunidad», lo cual implica que «la Constitución no se limita a la ordenación de la vida estatal. Sus normas abarcan también -de forma especialmente clara en garantías tales como las del matrimonio y la familia, la propiedad, la educación o la libertad del arte y la ciencia- las bases de la ordenación de la vida no-estatal» (Hesse, 1992, p. 16; véase también: Hesse, 2001, p. 5).

190 Es evidente entonces que frente al concepto de constitución dejamos de lado el esencialismo conceptual, muy extendido entre los juristas. Como lo explican L. Martínez y J. Fernández, para esta visión «la definición debe recoger y reflejar la esencia inmutable de las cosas. Cada cosa tiene un núcleo que es lo que constituye su esencia inmutable y ahistórica y que es lo que la diferencia de las demás» (Martínez y Fernández, 1994, 
aunque puede acudirse a las herramientas analíticas que ha desarrollado el «constitucionalismo descriptivo», esto no significa dejar de lado el componente ideológico y valorativo del «constitucionalismo prescriptivo», de manera que ambos se erigen como dos visiones complementarias de un mismo fenómeno. A partir de este enfoque integral es posible concebir a la constitución y al constitucionalismo como fenómenos históricos que se originan en la intersección del ámbito social de lo político y del ámbito normativo del derecho.

Hay una extendida concepción sobre el derecho que considera que éste está integrado por normas, en concreto por prescripciones o preceptos ${ }^{191}, \mathrm{y}$ que ellas garantizan, a su vez, que ciertas cosas sucedan de cierta manera. Esta garantía se materializa en la existencia de funcionarios, por ejemplo los jueces, encargados de hacer cumplir lo que las normas dicen. Si una norma establece una cosa y nadie la cumple, ni nadie la puede hacer cumplir, o no

p. 28). De acuerdo con C. S. Nino «este tipo de esencialismo conceptual clásico quedó bastante desacreditado por la expansión de un convencionalismo que cuestionó severamente sus presupuestos ontológicos y epistemológicos. (...) ¿Por qué no aceptar que los conceptos son creaciones convencionales de la sociedad humana para agrupar los objetos y los fenómenos que se dan en la experiencia o que son necesarios para entender esa experiencia sobre la base de ciertas propiedades comunes, que son seleccionadas de acuerdo a las necesidades del entendimiento y de la comunicación?» (Nino, 1994, p. 29). Respecto del derecho, este mismo autor señala que «lo apropiado sería adoptar una posición convencionalista. Según esta posición, el concepto de derecho surge de estipulaciones y prácticas que tienen en cuenta las necesidades del discurso en el que ese concepto se emplea. La consecuencia inmediata de esta posición es la admisión de que puede haber una pluralidad de conceptos de derecho, ya que las necesidades del discurso pueden variar en y con el discurso» (Nino, 1994, p. 32). Es evidente que la pluralidad conceptual que implica el convencionalismo también puede introducirse al análisis del concepto de constitución y de constitucionalismo, tal como hemos tratado de hacerlo en este trabajo. Ahora bien, el hecho de que para nuestros propósitos analíticos asumamos una concepción convencionalista de las definiciones no supone necesariamente descartar otro tipo de objetivos frente al concepto de constitución, en concreto el de proponer uno. En este sentido, G. Sartori ha puesto de presente que «si creemos, al menos, que un discurso racional y un vocabulario inteligible ha de ser preservado, entonces el significado de "constitución" debe ser definido mediante una prueba histórica y tiene que ser determinado por una información adecuada», razón por la cual «la equivalencia "constitución = cualquier forma de estado" es, por ende, no la más antigua sino de hecho la más reciente flexibilización del concepto, que refleja tanto la ilusión jurídica de alcanzar un derecho universal "purificado" y despolitizado, como el propósito de explotar la palabra constitución como una palabra engañosa» (Sartori, 1962, pp. 859, 863).

191 Véase supra n. 16. 
se espera que alguien la pueda hacer cumplir, dudamos de que esa norma exista. Para evitar que las normas tengan este carácter difuso e ineficaz, dice Herbert Hart, el derecho establece «reglas de adjudicación» a partir de las cuales se le otorga poder a ciertas personas para que las hagan cumplir (Hart, 1963, p. 120). En el mundo de la política, en cambio, es hasta cierto punto normal que las cosas no suceden de la manera como fueron previstas. La política es el reino de las propuestas y de las promesas, de tal manera que sólo una parte de ellas se convierte en realidad. Esto no quiere decir que los políticos siempre puedan hacer, de manera impune, promesas que no van a cumplir, sino que, como lo explicaba Max Weber, existe una cierta tolerancia de parte de los electores respecto de la ineficacia de tales promesas (Weber, 2006 p. 36). La política es una práctica que mira hacia el futuro, intentando determinarlo, pero no siempre puede hacerlo y así se suele aceptar, aunque muchas veces a regañadientes. El derecho en cambio mira hacia el presente e intenta determinarlo a través de procedimientos claros y previstos de antemano que pueden ser controlados y confrontados con los hechos.

Es cierto que esta distinción entre derecho y política no es tan clara como parece. Así, por ejemplo, la pérdida de las elecciones puede ser vista como una especie de sanción para políticos temerarios. En algunos países existe la llamada «revocatoria del mandato» de gobernantes que desconocen lo que prometen en sus campañas, lo cual significa que los programas políticos funcionan casi como imperativos. De otra parte, en el derecho las cosas no son siempre tan determinantes como se cree. Con frecuencia las normas son susceptibles de varias interpretaciones y son los jueces y otros funcionarios los que terminan decidiendo, políticamente, por una interpretación u otra ${ }^{192}$. Además, el derecho no siempre está compuesto por normas provistas de sanciones. A veces contiene sólo principios y orientaciones generales cuya fuerza impositiva es muy limitada.

Así pues, visto desde un punto de vista sociológico, el concepto de constitución parece estar localizado en este terreno difuso entre el mundo

192 De hecho hay concepciones sobre el derecho, por ejemplo en el debate contemporáneo las denominadas «teorías críticas del derecho» de autores como D. Kennedy (Kennedy, 1997) y M. Tushnet (Tushnet, 1984), que consideran que la verdadera naturaleza del derecho es la política y que ello se manifiesta en el hecho de que los jueces, en los casos difíciles -que son por lo general los casos más trascendentes-, primero toman una decisión política sobre los casos y luego la justifican jurídicamente. Véase al respecto: Uprimny y Rodríguez (2006, p. 46). 
de lo normativo y el mundo del poder político. De allí obtiene su riqueza y su complejidad. Este carácter intermedio, entre las promesas políticas y las prescripciones normativas, puede ser ilustrado a través de la explicación de cuatro importantes tensiones constitucionales. La primera de ellas se refiere a la relación de causalidad entre el derecho y el poder político. ¿Es la constitución la que origina el poder político o es el poder político el que da origen a la constitución? Este problema se ha planteado desde la Grecia antigua a través de la discusión sobre el mejor gobierno. Dos posiciones se han disputado la solución de este problema: de un lado, los defensores del gobierno de los hombres y, del otro, los defensores del gobierno de las leyes (Bobbio, 1996, p. 167-168). La defensa del gobierno de las leyes se encuentra plasmada en textos tan antiguos como los de Aristóteles ${ }^{193}$ y recorre toda la historia occidental, pasando por el Medioevo y las revoluciones modernas hasta el constitucionalismo contemporáneo. Por su parte, la concepción que subyace al gobierno de los hombres tiene sus raíces en la noción antigua del gobernante sabio o en la del soberano-padre (visión paternalista del poder) (Foucault, 1990). Esta segunda tendencia se manifiesta, por ejemplo, en la idea de la supremacía de la voluntad general de Rousseau y, en los siglos XIX y XX, adquiere una relevancia especial en los desarrollos del concepto de estado de excepción de K. Schmitt ${ }^{194}$ y en el postulado del carácter inevitable de la dictadura del proletariado ${ }^{195}$. Mientras que estas tendencias consideran que en presencia de un poder político que expresa la voluntad general (por ejemplo, un partido triunfante o un líder aclamado por la mayoría) no es adecuado ni conveniente imponerle restricciones, lo cual significa que ese poder debe considerarse como soberano, quienes sostienen la tesis del gobierno de las leyes estiman, por el contrario, que toda voluntad política debe ser encausada legalmente de tal manera que se eviten los riesgos de arbitrariedad y de abuso del poder. Por lo demás, en estas dos concepciones se pone de presente la tensión entre los elementos jurídicos y los

193 «Es preferible, pues, conforme a este razonamiento, que la ley gobierne y no cualquiera de los ciudadanos, y aun si [es] mejor que gobiernen varios, habría que constituirlos en guardianes y ministros de las leyes (...)». Aristóteles, La Política, 1287a (Aristóteles, 2000, p. 158).

194 A propósito de Hobbes, Carl Schmitt comenta que «la soberanía del derecho significa únicamente la soberanía de los hombres que imponen las normas jurídicas y se sirven de ellas (...)» (Schmitt, 1991, p. 94); sobre la importancia del voluntarismo político en Schmitt, véase el trabajo sobre este autor de M. Kaufmann (1989).

195 «El poder político, hablando propiamente, es la violencia organizada de una clase para la opresión de otra» (Marx y Engels, 2007, p. 176). 
elementos políticos de la democracia. Mientras una tendencia, caracterizada por un profundo optimismo antropológico, concentra sus esperanzas en la voluntad de los mejores hombres de la sociedad para dirigir el gobierno, la otra, pesimista desde el punto de vista antropológico, desconfía de un poder determinado por la voluntad individual y propone el sometimiento general de los gobernantes a una ley previa. En el primer caso el factor político es la fuente del derecho, en el segundo, el derecho es la fuente de la actividad política. Para los primeros una norma de control debe primar sobre la decisión política, para los segundos debe suceder lo contrario ${ }^{196}$.

La segunda tensión, vinculada con la anterior, se refiere a la relación entre institucionalización y democratización. Desde finales del siglo XVIII la historia constitucional se ha debatido entre estos dos extremos. La Revolución francesa y sobre todo la constitución de 1793, quiso que el derecho constitucional dependiera de la voluntad política de los representantes del pueblo. ¿Cómo podría ser de otra manera si la voluntad general y la soberanía radicaban en el pueblo mismo? Sin embargo, este protagonismo de los actores políticos debilitó las instituciones y luego condujo al estado de excepción y al terror. El siglo XIX reaccionó contra la presencia incontrolada de los actores políticos en el escenario constitucional y condujo a la defensa de las instituciones y del derecho, por encima de los actores y de las voluntades políticas. De aquí surgió un modelo constitucional conservador, aferrado a las maquinarias burocráticas, inmutable frente a las convulsiones del mundo político y de carácter esencialmente estatalista. La historia constitucional del siglo XX intentó conciliar estos dos factores, tratando de lograr el mayor grado posible de participación democrática y de presencia e incidencia política de los actores sociales, compatible con un grado máximo de estabilidad institucional y de firmeza de las reglas

196 Aunque la oposición entre el «gobierno de las leyes» y el «gobierno de los hombres» se ha presentado aquí de manera bastante marcada, conviene matizarla señalando, como lo hace N. Bobbio, que dentro del primero puede distinguirse entre el gobierno sub lege, el gobierno que se ejerce de acuerdo con leyes preestablecidas, y el gobierno per leges, el que se ejerce preferentemente por medio de la promulgación de normas generales y abstractas, y no mediante mandatos individuales y concretos. No se trata, sin embargo, de dos modelos incompatibles, pues «en la formación del Estado moderno, la doctrina del constitucionalismo, en la que se resume toda forma de gobierno sub lege, camina paralelamente con la del primado de la ley como fuente del derecho, entendiendo la ley, por un lado, como la máxima expresión de la voluntad del soberano, (...) y, como tal, opuesta a la costumbre; por el otro como norma general y abstracta y, como tal, contraria a los mandatos dados» (Bobbio, 1996, p. 173). 
jurídicas sobre los actores y los acontecimientos. El modelo constitucional actual, conocido como «Estado social de derecho», en parte es resultado de esta pretensión.

La tercera tensión se refiere a la relación entre constitución y progreso social. En muchos países se piensa que el destino social depende en gran medida de que se cuente con buenas constituciones, que contengan la expresión de las ilusiones en una sociedad futura mejor y más justa. En estos casos la vinculación entre progreso social y constitución política es vista como algo natural y, como consecuencia de ello, esta última se concibe como un documento político que conecta el presente con el futuro de la sociedad (Preuss, 1995). Pero esta manera de ver las constituciones contrasta con otra según la cual la constitución es un documento jurídico destinado a impedir que existan abusos del poder y cuya función principal es proteger las libertades y los derechos que las personan ya disfrutan. En este orden de ideas, para K. C. Wheare hay una línea divisoria «entre los que considera una Constitución originaria y casi exclusivamente un documento legal donde hay un lugar para las normas legales y, prácticamente, para nada más, y los que opinan que una Constitución es como un manifiesto, una confesión de fe, una declaración de ideales» (Wheare, 1975, p. 37). Así, mientras que para la primera de estas perspectivas la constitución tiene sentido en tanto ratifica una realidad política que se consolidó en el pasado, para la segunda, en cambio, la constitución transforma una realidad por más arraigada que esté desde tiempo atrás. En otras palabras, en el primer caso la constitución conserva lo que se logró en una revolución hace tiempo sucedida; en el segundo la constitución es una revolución en acto.

No obstante, la distinción entre estos dos tipos de constitución tiene un carácter más analítico que descriptivo. En la práctica, todas las constituciones se mueven en esta frontera difusa entre el derecho y la política, y entre el pasado y el futuro. Lo que pasa es que hay todo un espectro de casos entre aquellas con una estructura discursiva más cercana al mundo de lo político y aquellas con una estructura discursiva más afín a lo jurídico. Hay que advertir, además, que esta distinción es propia de un punto de vista externo propio de algo que podríamos denominar «sociología del derecho constitucional» y que, por lo general, interesa muy poco a quienes adoptan un punto de vista interno, propio de la dogmática constitucional misma. Según esta última visión todo lo que está en las constituciones tiene fuerza normativa y por lo tanto no hay normas que puedan ser consideradas como 
simples aspiraciones políticas ${ }^{197}$. Sin embargo, este punto es objeto de debate entre los juristas. Algunos de ellos consideran que las constituciones futuristas o aspiracionales son simple retórica política y que deben ser desatendidas por el Estado, por lo menos en el corto plazo $^{198}$.

Las constituciones vigentes en algunos países de Latinoamérica (Colombia, Bolivia, Ecuador, Guatemala y Brasil, entre otras) parecen asemejarse al segundo tipo, es decir, al documento político en el que se consagra una visión de la sociedad que está por realizarse, al punto de que es posible identificar un «constitucionalismo aspiracional» ${ }^{199}$. Ese tipo de constituciones se caracterizan por no lograr la efectividad completa de sus contenidos normativos (en eso se parecen al discurso político). El resultado de esta situación es una disociación notoria entre las normas, por un lado, y las realidades sociales y políticas que aquellas pretenden transformar, por el otro ${ }^{200}$. Esta brecha está inscrita en su naturaleza futurista y aspiracional.

197 Ejemplo de esta concepción es la noción de constitución como norma suprema a la que se aludió más atrás.

198 En este sentido, K. C. Wheare considera que siendo la Constitución «ante todo un documento legal», «tiene por objeto establecer las normas legales supremas. Por consiguiente, debe limitarse en lo posible a proclamar normas legales, no opiniones, aspiraciones, directivas o tendencias políticas» (Wheare, 1975, p. 37). De modo similar, para P. Bastid hay que ser escéptico frente a las virtudes transformadoras de las constituciones, pues «es conveniente no exagerar ni los vicios ni las virtudes de un determinado texto fundamental. Ninguno ha transformado jamás las costumbres de una nación, jamás ha logrado ni mejorarlas ni corromperlas» (Bastid, 1985, p. 186, n. 53). En este orden de ideas, respecto del derecho constitucional K. Hesse considera que «cuanto mayor sea la conexión de sus presupuestos con las circunstancias de la situación histórica, procurando conservar y desarrollar lo que ya se halla esbozado en la disposición individual del presente, tanto mejor conseguirán estos preceptos desplegar su fuerza normativa» (Hesse, 1992, p. 26). Por consiguiente, «cuanto más conecte el Derecho Constitucional con tales circunstancias, cuanto mejor asuma las fuerzas y tendencias de cada época, mejor podrá desplegar sus efectos. Cuando intente aferrarse a formas históricamente superadas o cuando, por el contrario, se proponga una utopía, fracasará inevitablemente ante la realidad» (Hesse, 2001, p. 8).

199 Para M. García Villegas la expresión «constitucionalismo aspiracional» designa «la concepción que liga la constitución con el progreso y que puede ser rastreada a partir de Rousseau y del movimiento jacobino en la Revolución Francesa», mientras que con la expresión «constitucionalismo preservador» se asocia la constitución con la protección del status quo (García Villegas, 2006, p. 205).

200 De todas formas, como lo pone de presente D. Grimm, hay una relación especial entre la constitución como norma y las realidades que pretende regular, dado que «la constitución normativa encuentra siempre una constitución empírica previa y debe imponerse a ella. En tales circunstancias la relación entre ambas, la pretensión jurídica y 
La constitución no expresa el país que existe sino el que se quiere que exista. Constituciones como éstas suelen prosperar en sociedades en las cuales existe una gran insatisfacción con la realidad presente. Es interesante comparar estas constituciones con las de otros países, en donde el propósito de conservar lo que se ha conseguido en el pasado (por lo general a partir de una revolución) suele prevalecer sobre el cambio social y la búsqueda de un futuro mejor, lo cual hace que su contenido se acomode mejor a la lógica jurídica de regulación del presente. El hecho de que constituciones aspiracionales prosperen allí donde menos garantizados están los derechos $y$ en donde menos recursos existen para lograr un cambio social no deja de ser una perturbadora paradoja para el constitucionalismo de los países latinoamericanos. ¿Qué naturaleza tienen nuestras normas constitucionales cuando consagran un futuro ideal? No es fácil ponerse de acuerdo sobre el significado de una constitución semejante y prueba de ello son los intensos debates que giran en torno al sentido y alcance de las constituciones que corresponden a este modelo. De todas maneras, a pesar de dichas dificultades el constitucionalismo aspiracional tiene cierto poder emancipatorio en la medida en que «contiene un mensaje político en el cual se concreta la idea de esperanza depositada en los textos constitucionales, de manera que los actores [sociales] encuentran en dicho mensaje un pretexto para la acción política. (...) El constitucionalismo aspiracional puede incidir de manera favorable en la realidad social y política cuando es capaz de inculcar en la mente de los miembros de los movimientos sociales y de las personas, en general, un espíritu anticonformista, que se funda en la afirmación autorizada de que la injusticia existe y debe ser remediada». Por consiguiente, «las constituciones aspiracionales no con -contra una visión instrumentalista-códigos, sino terrenos jurídicos de lucha política» (García, 2006, pp. 225-227) 201.

la acomodación a los hechos (por lo demás, no investigada a fondo) no es unidireccional, sino de ida y vuelta. Los objetos de regulación del derecho constitucional tienen su propia dinámica y consistencia, lo cual repercute, a su vez, en la comprensión y aplicación de las normas constitucionales; a la inversa, su efectividad está determinada por la circunstancia de que operan en el plano simbólico del derecho. De ahí que las constituciones no puedan cambiar la realidad de forma inmediata, sino sólo influir indirectamente. Influencia que descansa en la posibilidad de legalizar o ilegalizar las relaciones de poder existentes y, de este modo, fortalecerlas o debilitarlas» (Grimm, 2006a, pp. 34-35).

201 Es más, ante el enfrentamiento entre un constitucionalismo preservador y uno aspiracional puede ponerse de presente, con G. ZAGREBELSKY, que mientras que «la constitución de la Revolución [francesa] miraba solamente hacia adelante» y «la 
La cuarta tensión constitucional se refiere a la relación entre la historia de las ideas políticas y la experiencia institucional. La constitución no sólo es un conjunto de instituciones y de normas, es también una práctica histórica en la cual se produce una reformulación permanente de las ideas sobre el derecho, el poder y el Estado. Dicho en otros términos, el surgimiento y también el desarrollo de las constituciones están fuertemente influenciados por el contexto social y político en el que existen. Entre ambos elementos hay una relación constitutiva, o de recíproca incidencia, de tal manera que no es posible entender ninguno de los dos sin el otro ${ }^{202}$. Este punto es importante por lo menos por dos razones íntimamente vinculadas. La primera de ellas es porque así se evitan dos visiones erróneas de la historia y la teoría constitucional: por un lado, una visión intelectualista según la cual las constituciones obedecen exclusivamente al pensamiento de sus redactores o de los pensadores que las concibieron. Según esto, las constituciones serían algo así como el elemento generador de las instituciones y, con estas, de la sociedad entera. De otra parte, es necesario abandonar una visión rígidamente materialista de la historia constitucional en la cual se desconoce la capacidad de las ideas para incidir por sí solas en la realidad social y se estima que son sólo las fuerzas sociales y los intereses ligados a dichas fuerzas los que producen las instituciones y el pensamiento constitucional. El intelectualismo jurídico adolece de un optimismo exagerado sobre el papel transformador de las constituciones mientras que el materialismo jurídico adolece de un pesimismo exagerado a este respecto. La historia constitucional, en cambio, es una prueba fascinante

constitución de la Conservación miraba solamente hacia atrás», «las constituciones de nuestro tiempo miran al futuro teniendo firme el pasado, es decir, el patrimonio de experiencia histórico-constitucional que quieren salvaguardar y enriquecer. (...) La "historia" constitucional no es un pasado inerte sino la continua reelaboración de las raíces constitucionales del ordenamiento que nos es impuesta en el presente por las exigencias constitucionales del futuro» (ZAGREBELSKY, 1995a, pp. 90-91).

202 H. Heller describe esta situación en estos términos: «la normalidad tiene que ser siempre reforzada y completada por la normatividad; al lado de la regla empírica de previsión ha de aparecer la norma valorativa de juicio. (...) Pues al lado de esta fuerza normativa de lo normal fáctico tiene también una gran importancia la fuerza normalizadora de lo normativo. (...) En realidad, sobre la infraestructura de la Constitución no normada, e influida esencialmente por esta infraestructura, se yergue la Constitución formada por normas en la cual, al lado de la tradición y el uso, desempeña su papel peculiar la función directora y la preceptiva, que tienen carácter autónomo y que, con frecuencia, deciden contra lo tradicional» (Heller, 1942, pp. 270-271). 
de la manera como intereses sociales y pensamiento político se construyen de manera recíproca ${ }^{203}$.

La segunda razón por la cual es importante adoptar esta visión histórica del constitucionalismo es porque ella permite entender mejor el papel que tanto el diseño institucional como los conflictos y las pasiones políticas han jugado en el avance del pensamiento constitucional. Así, de un lado, la historia del constitucionalismo es en buena parte el resultado de una práctica de ensayo-error a través de la cual se ha ido decantando un pensamiento jurídico-constitucional. Este pensamiento acumulado, fruto de la experiencia, es fundamental para entender el surgimiento de nuevas constituciones así como la suerte que éstas corren. En el constitucionalismo hay pues una buena dosis de ciencia y técnica jurídica que se ha ido agregando a través de la historia de las sociedades. Ahora bien, de otro lado, no hay que exagerar el valor que los juristas que diseñan instituciones han tenido en esta historia, entre otras cosas porque si de ellos dependiera todo, sería poco probable que se hubieren dado trasformaciones importantes, dado su talante frecuentemente conservador. Fue necesario que las pasiones políticas expresadas en catálogos ideológicos irrumpieran con fuerza en la historia constitucional de los pueblos para que las cosas cambiaran y se pusieran de presente nuevas posibilidades y nuevos rumbos. Por eso la imprudencia ideológica y la pasión política han jugado también un papel fundamental en la configuración del constitucionalismo. No sobra indicar, además, que al poner de relieve la importancia de la pasión y de la conflictividad política damos crédito a cierto espíritu constitucional latino, muy emparentado con la historia política de Francia.

El concepto de constitución es pues un concepto fronterizo entre el mundo normativo e institucional, por un lado, y el mundo del poder y de los actores políticos, por el otro. Este carácter híbrido explica muchas de las

203 G. Peces-Barba y E. Fernández afirman respecto de la historia de los derechos humanos (lo cual se aplica también a la de las constituciones y el constitucionalismo) que «quizás si lo que se pretende es evitar caer en los riesgos y equivocaciones de una visión idealista o de una visión materialista de la historia de los derechos humanos, lo más conveniente sea partir de una visión global, comprensiva de todos los factores históricos, que de entrada, y con carácter general, no da una especial relevancia a uno de ellos, en detrimento de los otros. Pensamos que ese equilibrio adecuado entre factores culturales, políticos, sociales o económicos ha de interpretarse adecuándolo a cada uno de los ejemplos históricos que se pretenden comprender, puesto que nunca funciona de la misma manera» (Peces-Barba \& Fernández, 1998, p. 5-6). 
tensiones internas del constitucionalismo -como las que hemos visto hasta ahora- $\mathrm{y}$ también pone de presente la necesidad de asumir una concepción comprehensiva e interdisciplinaria del concepto de constitución y de constitucionalismo, sin que ello implique poner en tela de juicio definiciones necesariamente técnicas o especializadas como las que proponen los juristas (a las que ya hemos hecho referencia). Así pues, en respuesta a la pregunta planteada al inicio del presente trabajo puede afirmarse que el derecho constitucional está marcado por tensiones internas entre lo jurídico y lo político que deben ser mantenidas y no simplemente resueltas por la vía de la exclusión de una de ellas.

\section{BIBLIOGRAFÍA}

Aalders, G.J. D. (1968). Die Theorie der gemischten Verfassung im Altertum, Ámsterdam: A.M. Hakkert.

Aguiló R., J. (2004a). «Sobre la constitución del Estado constitucional». En: Aguiló R., Josep. La Constitución del Estado Constitucional, Lima, Bogotá: Palestra, Temis.

—. (2004b). Cuatro pares de concepciones opuestas de la constitución. En Aguiló R., Josep. La Constitución del Estado Constitucional, Lima, Bogotá: Palestra, Temis.

Alexy, R.(1994). El Concepto y la validez del Derecho, trad. Jorge M. Seña, Barcelona: Gedisa.

Aquino, T. de (2000). Tratado de la ley. En Tratado de la ley. Tratado de la justicia. Gobierno de los príncipes, trad. de Carlos Ignacio González, México: Porrúa.

Ardant, P. (1993). La revision constitutionnelle en France. Problématique générale. En La révision de la Constitution: journées d'études des 20 mars et 16 décembre 1992, Aix-en-Provence: Presses Universitaires d'Aix-Marseille, París: Économica.

Aristóteles (2000). La política: politeia, trad. Manuel Briceño Jáuregui, Bogotá: Panamericana Editorial.

Bastid, P. (1985). L'idée de constitution, París: Economica.

Bayón, J. C. (2003). Derechos, democracia y constitución En Carbonell, Miguel (ed.), Neoconstitucionalismo(s), Madrid: Trotta.

Beaud, O. (2003). Constitution et constitutionnalisme. En Raynaud, Philipe y Rials, Stéphane (dir.), Dictionnaire de philosophie politique, París: Presses Universitaires.

—. (2009). «L'histoire du concept de constitution en France. De la constitution politique à la constitution comme statut juridique de l'Etat», Jus Politicum: Revue de droit politique, No. 3 (Autour de la notion de Constitution). 
Bobbio, N. (1994). Teoría General del Derecho, (trad. de Jorge Guerrerow), Bogotá: Temis. - (1996). ¿Gobierno de los hombres o gobierno de las leyes?. En El futuro de la democracia, (trad. José F. Fernández Santillán), México: Fondo de Cultura Económica.

Bodin, J. (2006). Los seis libros de la república, (trad. Pedro Bravo Gala), Madrid: Tecnos. Bolingbroke, H.St. J. (1997). Political writings, ed. David Armitage, Cambridge, Nueva York: Cambridge University Press.

Bryce. (1962). Constituciones flexibles y constituciones rígidas, (2 ${ }^{\mathrm{a}}$ ed.), Madrid: Instituto de Estudios Políticos.

Burke, E. (1996). Textos políticos, (1ª ed. 1942, trad. Vicente Herrero), México: Fondo de Cultura Económica.

Burlamaqui, J.-J. (1983). Principes du droit politique, Caen: Centre de Philosophie Politique et Juridique de l'Université de Caen, 2 vols.

Calvo García, Manuel (1994). Los fundamentos del método jurídico: una revisión crítica, Madrid: Tectnos.

Carbonell, M. (2007). El neoconstitucionalismo en su laberinto. En Carbonell, Miguel (ed.). Teoría del neoconstitucionalismo: ensayos escogidos, Madrid: Trotta, Instituto de Investigaciones Jurídicas-UNAM.

Cicerón, M.T. (1992). Sobre la República. Sobre las leyes, (trad. José Guillén), Madrid: Tecnos.

Clavero, B. (1998). Presentación. En: Matteucci, Nicola. Organización del poder y libertad: historia del constitucionalismo moderno, (trad. Francisco Javier Ansuátegui Roig y Manuel Martínez Neira), Madrid: Trotta.

Comanducci, P. (2003). Formas de (neo)constitucionalismo: un análisis metateórico, (trad. Miguel Carbonell). En Carbonell, Miguel (ed.), Neoconstitucionalismo(s), Madrid: Trotta.

- (2007). Modelos e interpretación de la constitución» (trad. Manuel Ferrer Muñoz). En Carbonell, Miguel (ed.). Teoría del neoconstitucionalismo: ensayos escogidos, Madrid: Trotta, Instituto de Investigaciones Jurídicas-UNAM.

Constant, B. (1872). Réflexions sur les Constitutions et les Garanties, avec une Esquisse de Constitution (1814-1818). En Cours de politique constitutionnelle ou Collection des ouvrages publiés sur le gouvernement représentatif, ed. Édouard Laboulaye, París: Guillaumin.

Dicey, A. V. (1915). Introduction to the Study of the Law of the Constitution, $8^{\mathrm{a}}$ ed., Londres: Macmillan.

Dippel, H. (2009). Constitución. En Constitucionalismo moderno, (trad. María Salvador Martínez), Madrid: Marcial Pons. 
Dworkin, R. (1995). Los derechos en serio, (trad. Marta Gustavino), Barcelona: Ariel.

Elster, J. (1999). Introducción. En Elster, Jon y Slagstad, Rune (eds.), Constitucionalismo y democracia, (trad. Mónica Utrilla y José Ricárdez), México: Fondo de Cultura Económica.

Ely, J. H.(1997). Democracia y desconfianza: una teoría del control constitucional, (trad. Magdalena Holgín), Bogotá: Siglo del Hombre, Universidad de los Andes.

Everson, S. (1996). Introduction. En Aristóteles. The Politics and the Constitution of Athens, Cambridge, Nueva York: Cambridge University Press.

Favoreu, L. (coord.) (1999). Droit constitutionnel, $2^{\mathrm{a}}$ ed., París: Dalloz.

Fernández Sarasola, Ignacio (2004). Proyectos constitucionales en España (17861824), Madrid: Centro de Estudios Políticos y Constitucionales.

Ferrajoli, L.(1998). Derecho y razón: Teoría del garantismo penal, trad. Perfecto Andrés Ibáñez et. al., Madrid: Trotta.

Ferreres Comella, V. (2007). Justicia constitucional y democracia, Madrid: Centro de Estudios Políticos y Constitucionales.

Finer, S.E. (1997). The history of government. Vol. 1 Ancient monarchies and empires, Nueva York: Oxford University Press.

Fioravanti, M. (2001). Constitución: de la antigüedad a nuestros días, trad. Manuel Martínez Neira, Madrid: Trotta.

Foucault, M. (1990). Omnes et singulatim: hacia una crítica de la razón política. En Foucault, Michel; Savater, Fernando; Varela, Julio y Alvarez-Uría, Fernando. La vida de los hombres infames: ensayos sobre desviación y dominación, Madrid: La Piqueta.

Friedrich, C. J. (1974). Constitución y constitucionalismo. En: Sills, David L. (dir.), Enciclopedia internacional de las ciencias sociales, vol. 3. Madrid: Aguilar.

Friedrich, C. J. (1975). Gobierno constitucional y democracia: Teoría y práctica en Europa y América, (trad. Agustín Gil Lasierra), 2 vols. Madrid: Instituto de Estudios Políticos,

Fritz, K. V. (1975). The theory of the mixed constitution in antiquity, Nueva York: Arno Press.

García, E. (1983). La constitución como norma y el tribunal constitucional, $3^{\mathrm{a}}$ ed., Madrid: Civitas.

García, I. L. (ed. y trad.) (1889). Cuerpo del derecho civil romano: A doble texto traducido al castellano del latino publicado por los hermanos Kriegel, Hermann y Osenbruggen. Vol.1, Primera parte Instituta-Digesto, Barcelona: Jaime Molinas Editor.

García, M. (2006). El derecho como esperanza: constitucionalismo y cambio social en América Latina, con algunas ilustraciones a partir de Colombia. En: García, 
M., Uprimny, R. \& Rodríguez, C. A. ¿Justicia para todos?: Sistema judicial, derechos sociales y democracia en Colombia, Bogotá: Grupo Editorial Norma. García, M. (2000). Derecho constitucional comparado, Madrid: Alianza Editorial. Grimm, D. (2006a). Constitución. En: Constitucionalismo y derechos fundamentales, (trad. Raúl Sanz Burgos y José Luis Muñoz), Madrid: Trotta.

- (2006b). Condiciones y consecuencias del nacimiento del constitucionalismo moderno. En Constitucionalismo y derechos fundamentales, (trad. Raúl Sanz Burgos y José Luis Muñoz), Madrid: Trotta.

- (2006c). El concepto de constitución en su desarrollo histórico. En Constitucionalismo y derechos fundamentales, (trad. Raúl Sanz Burgos y José Luis Muñoz), Madrid: Trotta.

Guastini, R.(2001). Rigidez constitucional y límites a la reforma en el ordenamiento italiano. En: Guastini, R. Estudios de teoría constitucional, ed. Miguel Carbonell, México: Distribuciones Fontamara.

_ (2003). La "constitucionalización” del ordenamiento jurídico: el caso italiano, (trad. José María Lujambio). En Carbonell, M. (ed.), Neoconstitucionalismo(s), Madrid: Trotta.

(2007). Sobre el concepto de constitución, (trad. Miguel Carbonell). En Carbonell, Miguel (ed.). Teoría del neoconstitucionalismo: ensayos escogidos, Madrid: Trotta, Instituto de Investigaciones Jurídicas-UNAM.

Guzmán, A. (2002). El vocabulario histórico para la idea de constitución política, Revista de Estudios Histórico-Jurídicos, No. XXIV.

Habermas, J. (1998). Facticidad y validez: sobre el derecho y el Estado democrático de derecho en términos de teoría del discurso, (trad. Manuel Jiménez Redondo), Madrid: Trotta.

Hamilton, W. H. (1959). Constitutionalism. En Seligman, E. R. A. y Anderson, R. (ed.), Encyclopaedia of the social sciences, vol. 3-4. Nueva York: MacMillan

Hart, H.L.A. (1963). El concepto de derecho, (trad. Genaro R. Carrió), Buenos Aires: Abeledo-Perrot.

Hartney, M. (1988). Etre/devoir-être. En: Arnaud, André-Jean (dir.), Dictionnaire encyclopédique de théorie et de sociologie du droit, Paris; Librairie générale de droit et de jurisprudence, Story-Scientia.

Hegel, G.W. F. (2010). La constitución de Alemania, (trad. Dalmacio Negro Pavón), Madrid: Tecnos.

Heller, H. (1942). Teoría del Estado, ed. Gerhart Niemeyer, (trad. Luis Tobio), México: Fondo de Cultura Económica.

Hernández, R. (1989). Historia de la Filosofía del Derecho Contemporánea, Madrid: Tecnos. 
Hesse, K. (1992). Concepto y cualidad de la constitución. En Escritos de derecho constitucional, (trad. y selección Pedro Cruz Villalón), Madrid: Centro de Estudios Constitucionales.

- (2001). Constitución y derecho constitucional. En Benda, E. et al., Manual de derecho constitucional, (ed. y trad. Antonio López Pina), Madrid: Marcial Pons, Barcelona: Ediciones Jurídicas y Sociales.

Hobbes, T.(1980). Leviatán, o la materia, forma y poder de una república, eclesiástica y civil, (trad. Manuel Sánchez Sarto), México: Fondo de Cultura Económica.

Jellinek, G. (1991). Reforma y mutación de la constitución (1906), (trad. Christian Förster), Madrid: Centro de Estudios Constitucionales.

Jellinek, G. (2000). Teoría general del Estado (1911), (trad. Fernando de los Ríos), Mexico : Fondo de Cultura Económica.

Kaufmann, M. (1989). ¿Derecho sin reglas?: los principios filosóficos de la teoría del estado y del derecho de Carl Schmitt, trad. Jorge M. Seña., Barcelona: Editorial Alfa.

Kelsen, H. (1988). La garantía jurisdiccional de la Constitución (la justicia constitucional), (trad. Juan Ruiz Manero). En Kelsen, H. Escritos sobre la democracia y el socialismo, Madrid: Debate.

- (2003). Teoría Pura del Derecho, (trad. Roberto J. Vernengo de la $2^{\mathrm{a}}$ ed). (1960), México: Porrua.

Kennedy, D. (1997). A critique of adjudication: fin de siècle, Cambridge: Harvard University Press.

Kenyon, J. P. (1966). The Stuart Constitution, 1603-1688: documents and commentary, Cambridge: Cambridge University Press.

Koselleck, R. (2007). Begriffsgeschichtliche Problem der Verfassungsges chichtsschreibung. En Begriffsgeschichten. Studien zur Semantik und Pragmatik der politischen und sozialen Sprache, Frankfurt: Suhrkamp.

Kriele, M. (1980). Introducción a la teoría del estado: fundamentos históricos de la legitimidad del estado constitucional democrático, (trad. Eugenio Bulygin), Buenos Aires: Depalma.

Lassalle, F.(1997). ¿Qué es una constitución?. En ¿Qué es una constitución?, (trad. Wenceslao Roces), (pp. 75-120). Barcelona: Ariel.

Lintott, A. W. (1999). The constitution of the Roman Republic, Oxford, Nueva York: Clarendon Press.

Locke, J. (2000). Segundo Tratado sobre el Gobierno Civil: Un ensayo acerca del verdadero origen, alcance y fin del Gobierno Civil, (trad. Carlos Mellizo), Madrid: Alianza Editorial. 
Löewenstein, K. (1951). Reflections on the Value of Constitutions in our Revolutionary Age. En Zurcher, A. J. (ed.). Constitutions and constitutional trends since World War II: an examination of significant aspects of postwar public law with particular reference to the new constitutions of Western Europe, Nueva York: New York University Press.

— (1983). Teoría de la Constitución, (trad. Alfredo Gallego A.), Barcelona: Ariel.

Luhmann, N. (1990). "Verfassung als evolutionäre Errungenschaft», Rechtshistorisches Journal, No. 9.

Maddox, G.(1989). Constitution. En: Ball, T., Farr, J. \& Hanson, R.L. (ed.), Political innovation and conceptual change, Cambridge: Cambridge University Press.

Maistre, J. de (1953). Consideraciones sobre Francia, estudio preliminar de Rafael Gambra, (trad. de Carmela Gutiérrez de Gambra), Madrid: Rialp.

Marquardt, B. (ed.) (2009). El bicentenario del constitucionalismo moderno en Colombia: documentos del primer siglo, Bogotá: Universidad Nacional de Colombia.

Martínez, L. y Fernández, J. A. (1994). Curso de teoría del Derecho y metodología jurídica, Barcelona: Editorial Ariel.

Marx, K. \& Engels, F. (2007). El manifiesto comunista, (introd. y notas Gareth S. Jones, trad. Jesús Izquierdo Martín), México: Fondo de Cultura Económica, Turner.

Matteucci, N. (1998). Organización del poder y libertad: historia del constitucionalismo moderno, (trad. Francisco Javier Ansuátegui Roig y Manuel Martínez Neira,) Madrid: Trotta.

(2005). Constitucionalismo. En Bobbio, N., Matteucci, N.y Pasquino, G. Diccionario de política, México: Siglo XXI editores.

McIlwain, Ch. H. (1991). Constitucionalismo antiguo y moderno, trad. Juan José Solazábal Echavarría, Madrid: Centro de Estudios Constitucionales.

Montesquieu, C. L.de S., barón de la Brede y (1984). Del espíritu de las leyes, prólogo Enrique Tierno Galván, trad. Mercedes Blázquez y Pedro de Vega, Barcelona: Ediciones Orbis, 2 vols.

Mortati, C. (2000). La constitución en sentido material, trad. Almudena Bergareche G., Madrid: Centro de Estudios Políticos y Constitucionales.

Mousourakis, G. (2003). The historical and institutional context of Roman law, Burlington: Ashgate, Dartmouth.

Nino, C. S. (1992). Fundamentos de derecho constitucional: análisis filosófico, jurídico y politológico de la práctica constitucional, Buenos Aires: Editorial Astrea.

- (1994). Derecho, moral y política. Una revisión de la teoría general del derecho. Barcelona: Ariel. 
Nippel, W. (1980). Mischverfassungstheorie und Verfassungsrealität in Antike und früher Neuzeit, Stuttgart: Klett-Cotta.

Olivecrona, K. (1959). El derecho como hecho. El imperativo de la ley, trad. Gerónimo Cortés Funes, Buenos Aires: Depalma.

Otto, I. de (1999). Derecho constitucional: Sistema de fuentes, Barcelona, Ariel.

Paine, T. (1984). Derechos del hombre: respuesta al ataque realizado por el Sr. Burke contra la revolución francesa, (trad. Fernando Santos Fontenla), Madrid: Alianza Editorial.

Peces-Barba, G. \& Fernández, E. (1998). Introducción: La historia de los derechos humanos: un proyecto comprensivo. En Peces-Barba, G. y Fernández, E. (dir.). Historia de los derechos fundamentales. Tomo I: Tránsito a la modernidad Siglos XVI y XVII, Madrid: Dykinson.

Pegoraro, L. (2008). Revisión constitucional. El caso italiano en el contexto de la teoría general y del derecho comparado, Boletín mexicano de derecho comparado, Número conmemorativo, sexagésimo aniversario.

Perales, A. E. (1986). Las convenciones constitucionales, Revista de estudios políticos, $\mathrm{N}^{\mathrm{o}} 53$.

Pérez, F. J. (1986). La reforma de la Constitución, Revista de derecho político, № 22.

Perry, M. J. (1998). What is "the constitution" (and other fundamental questions). En Alexander, L. (ed.). Constitutionalism: philosophical foundations, Cambridge: Cambridge University Press.

Polibio (1983). Historias, (intr. A. Díaz T., trad. Manuel Balasch Recort), v. 2 (libros V-XV). Madrid: Editorial Gredos.

Portillo, J. M. (2010). "La constitución en el atlántico hispano, 1808-1824», Fundamentos, Cuadernos monográficos de Teoría del Estado, Derecho Público e Historia Constitucional, № 6 .

Preuss, U. K. (1995). Constitutional revolution: the link between constitutionalism and progress, (trad. Deborah Lucas Schneider, Atlantic Highlands). New Jersey: Humanities Press.

Prieto, L. (2003). Neoconstitucionalismo y ponderación judicial. En Carbonell, M. (ed.), Neoconstitucionalismo(s), Madrid: Trotta.

Ramírez, G. A.(2005). Límites de la reforma constitucional en Colombia: el concepto de constitución como fundamento de la restricción, Bogotá: Universidad Externado de Colombia.

Raynaud, P. (2003). Constitutionalisme. En Alland, D.y Rials, S. (dir.), Dictionnaire de la culture juridique, París: Presses Universitaires de France. 
Rigaudière, A. (1997). Pratique politique et droit public dans la France des $14^{e}$ et $15^{e}$ siècles, Archives de philosophie du droit, tome 41.

Rodríguez, R. (2006). El control constitucional de la reforma a la Constitución, Madrid: Dykinson.

Rodríguez, A. A. (2009). La interacción entre ordenamientos jurídicos: Trasplante, recepción, adaptación e influencia en el derecho. En Revista Iusta, No. 31. - (2011). La circulation des modèles juridiques: L'exemple de la réception en Colombie de la doctrine constitutionnelle française du début du vingtième siècle, Revista virtual Via Inveniendi et Iudicandi, Vol 5. No 1, $9^{\text {a }}$ ed.

Ross, A.(2001). Sobre la auto-referencia y un difícil problema de derecho constitucional. En Ross, A. El concepto de validez y otros ensayos, (trad. Ernesto Garzón Valdés y Eugenio Bulygin), México: Distribuciones Fomtamara.

Ruipérez, J.(1997). Una cuestión nuclear para la teoría de derecho constitucional: sobre la reforma de la Constitución y sus funciones en el estado constitucional democrático, Anuario da Facultade de Dereito da Universidade da Coruña, $\mathrm{N}^{\circ} 1$.

Sartori, G. (1962). Constitutionalism: a Preliminary Discussion, The American Political Science Review, Vol. 56, No. 4.

Schmitt, C. (1991). El concepto de lo político: texto de 1932 con un prólogo y tres corolarios, (trad. Rafael Agapito), Madrid: Alianza Editorial.

- (2001). Teoría de la Constitución, (trad. Francisco Ayala), Madrid: Alianza Editorial.

Sièyes, E. (1993). Preliminar de la constitución. Reconocimiento y exposición razonada de los derechos del hombre y del ciudadano (1789). En Pantoja, D. (ed.). Escritos políticos de Sieyès, México: Fondo de Cultura Económica.

Stourzh, G. (1977). Staatsformenlehre und Fundamentalgesetze in England und Nordamerika im 17. und 18. Jahrhundert. Zur Genese des modernen Verfassungsbegriffs. En Vierhaus, R. (ed.). Herrschaftsverträge, Wahlkapitulationen, Fundamentalgesetze, Göttingen: Vandenhoeck und Ruprecht.

(2007). Constitution: Changing Meanings of the Term from the Early Seventeenth Century to the Late Eighteenth Century. En: Stourzh, G. From Vienna to Chicago and back: essays on intellectual history and political thought in Europe and America, Chicago: University of Chicago Press.

Sunstein, C. R. (1999). Constituciones y democracias: epílogo. En: Elster, J. y Slagstad, R. (eds.), Constitucionalismo y democracia, (trad. Mónica Utrilla y José Ricárdez), México: Fondo de Cultura Económica.

Tillet, E. (1998). Les ambiguïtés du concept de constitution au XVIIIe siècle : l'exemple de Montesquieu. En Pensée politique et droit: Actes du XIIe colloque 
de l'Association française des historiens des idées politiques, Aix-en-Provence: Presses Universitaires d'Aix-Marseille.

- (2001). La Constitution anglaise, un modèle politique et institutionnel dans la France des Lumières, Aix-en-Provence: Presses Universitaires d'Aix-Marseille.

Tomás, F. (1996). Constitución. En Díaz, E. y Ruíz, A., Filosofía política II: Teoría del Estado, Madrid: Trotta..

Troper, M. (1994). Le concept de constitutionnalisme et la théorie moderne du droit. En Troper, M. Pour une théorie juridique de l'État, París: Presses Universitaires de France.

(1999). La máquina y la norma: Dos modelos de Constitución, (trad. Juan Ruiz Manero), Doxa: Cuadernos de filosofia del derecho, № 22.

- (2001a). El problema de la interpretación y la teoría de la supralegalidad constitucional. En Troper, M., Por una teoría jurídica del Estado, (trad. María Venegas Grau), (pp. 273-296). Madrid: Dykinson,

Troper, M. (2001b). El concepto de constitucionalismo y la teoría moderna del derecho. En Troper, M. Por una teoría jurídica del Estado, (trad. María Venegas Grau), Madrid: Dykinson.

Tushnet, M. (1984). Critical Legal Studies and Constitutional Law: An Essay in Deconstruction, Stanford Law Review, Vol. 36, No. 1/2, Critical Legal Studies Symposium.

Uprimny, R. (1997). Estado social de derecho y decisión judicial correcta: un intento de recapitulación de los grandes modelos de interpretación jurídica. En: Botero, D. et al., Hermenéutica jurídica: Homenaje al maestro Darío Echandía, Bogotá: Universidad del Rosario.

Uprimny, R. y Rodríguez, A. A. Interpretación Judicial, 2a ed., Bogotá: Consejo Superior de la Judicatura, Escuela Judicial «Rodrigo Lara Bonilla», Universidad Nacional de Colombia, 2006.

Vanossi, J. R. (2002). Los límites del poder constituyente. En: Estudios de teoría constitucional, (pp. 241-330). México: Universidad Nacional Autónoma de México.

Vattel, E. de (1978). Le droit des gens ou Principes de la loi naturelle appliqués à la conduite et aux affaires des nations et des souverains, Paris: Hachette.

Vega, P. de (1991). La reforma constitucional y la problemática del poder constituyente, Madrid: Tecnos.

Verdú, P. L. (1994). Reflexiones en torno y dentro del concepto de Constitución: La Constitución como norma y como integración política, Revista de estudios políticos, $\mathrm{N}^{\mathrm{o}} 83$. 
- (1997). Teoría de la constitución como ciencia cultural, Madrid: Dykinson. Vizcardo y Guzmán, J. P. (2004). Carta dirigida a los españoles americanos, (ed. e introd. David Brading), México: Fondo de Cultura Económica.

Waldron, J. (1993). A Right-Based Critique of Constitutional Rights, Oxford Journal of Legal Studies, Vol. 13, No. 1.

Weber, M. (2006). Política y ciencia, (trad. Carlos Correas), Buenos Aires: Editorial Leviatán.

Wheare, K.C. (1975). Las constituciones modernas, Barcelona: Labor.

Zagrebelsky, G. (1995a). Historia y constitución, (trad. de Miguel Carbonell), Madrid: Trotta.

(1995b). El derecho dúctil. Ley, derechos, justicia, (trad. Marina Gascón), Madrid: Trotta. 

Esta obra se terminó

de imprimir en junio de 2016

con un tiraje de 500 ejemplares

en los Talleres Gráficos de

Grupo Editorial IBÁÑEZ

Carrera 69 Bis No. 36-20 Sur.

Tels: 2300731 - 2386035

Bogotá D.C. - Colombia 